Susana Narimatsu Sato

\title{
A infografia na divulgação científica: um estudo de caso da revista Pesquisa FAPESP
}

\author{
Dissertação apresentada à Escola de Comunicações \\ e Artes da Universidade de São Paulo para obtenção \\ do título de Mestre em Ciências da Comunicação \\ Área de Concentração: Estudos dos Meios e da \\ Produção Mediática. Linha de Pesquisa: Consumo e \\ Usos Midiáticos nas Práticas Sociais. Orientadora: \\ Profa Dra Sandra Maria Ribeiro de Souza
}


Autorizo a reprodução e divulgação total ou parcial deste trabalho, por qualquer meio convencional ou eletrônico, para fins de estudo e pesquisa, desde que citada a fonte.

snsato@usp.br

Catalogação na Publicação

Serviço de Biblioteca e Documentação

Escola de Comunicações e Artes da Universidade de São Paulo

Dados fornecidos pelo(a) autor(a)

Sato, Susana Nari matsu

A i nfografia na divulgação científica: um estudo de caso

da revista Pesquisa Fapesp/ Susana Nari matsu Sato. . São

Paulo: S. N. Sato, 2017.

$155 \mathrm{p.}: \mathrm{il}$.

Di ssertação (Mestrado) - Programa de Pós-Graduação em

Ciências da Comunicação. Escola de Comunicações e Artes 1

Universidade de São Paulo.

Ori entadora: Sandra Maria Ribeiro de Souza

Bi bl iografia

1. Design da informação 2. Di vulgação científica 3.

Infografia 4. Revista Pesquisa FAPESP 5. Comunicação visual

I. Souza, Sandra Maria Ribeiro de II. Título.

CDD 21.ed. - 302.2 


\section{Folha de aprovação}

Susana Narimatsu Sato

A infografia na divulgação científica:

um estudo de caso da revista Pesquisa FAPESP

Dissertação apresentada à Escola de Comunicações e Artes da Universidade de São Paulo para obtenção do título de Mestre em Ciências da Comunicação.

Aprovado em:

\section{Banca examinadora}

Prof. Dr.:

Julgamento:

Instituição:

Assinatura:

Prof. Dr.:

Julgamento:

Instituição:

Assinatura:

Prof. Dr.:

Julgamento:

Instituição:

Assinatura: 
para Deus

para Dan

para Shingo 


\section{Agradecimentos}

Agradeço à professora Sandra Souza pela confiança, pelos direcionamentos e por me ajudar a organizar ideias e objetivos.

Aos professores Eneus Trindade e Clice Mazzilli, pelas contribuições à época da qualificação.

Aos professores Marciel Consani (que me incentivou, desde a graduação, à incursão no mundo acadêmico), Andrea Limberto, Cláudia Lago, Dorinho Bastos, Hugo Fortes, Ismar Soares, Polise de Marchi, Rogerio Mugnaini e Roseli Figaro, por tornarem o processo de aprendizado tão fascinante.

À Ana Paula Campos, editora de infografia da revista Pesquisa FAPESP, por ter me ajudado de forma tão simpática e generosa, indicando referências, enviando material de apoio e respondendo pacientemente às minhas muitas dúvidas (muitíssimo obrigada!).

À editora de arte Mayumi Okuyama, à gerente de marketing e divulgação Paula lliadis, e à equipe da revista Pesquisa FAPESP pela disponibilidade e receptividade no dia da visita à redação.

Aos infografistas e ilustradores Gil Tokio e Beto Uechi pelas dicas e referências, pelo almoço e por nos receberam tão bem no Estúdio Pingado.

Aos amigos e colegas da ECA-USP, pelo apoio e trocas estimulantes.

À Carolina Modesto e Rosely Sousa, pelas dicas e amizade.

À Ana Caroline Padilha, Elizabeth Romani, Eunice Liu e Rafaela Carla Sousa, pela amizade, por me atraírem para o universo acadêmico e por me encorajarem desde o dia em que cogitei prestar o processo seletivo para o Mestrado.

À Mel Inoue, pelo cuidado e torcida, e por me trazer guloseimas nas horas mais perfeitas.

Às famílias Narimatsu e Sato, pelo incentivo.

Ao Shingo, pela paciência, amizade, companheirismo, cuidado, amor, carinho e apoio incondicionais; por segurar as pontas no dia a dia; pelos comentários pertinentes e contribuições generosas para este trabalho; e por querer compartilhar sua vida comigo.

Ao Dan, meu pequeno cientista, pelas alegrias diárias e pela história que estamos construindo juntos.

A Deus, por colocar em meu caminho as pessoas acima citadas e por ser a minha Rocha Eterna. 
SATO, S. N. A infografia na divulgação científica: um estudo de caso da revista Pesquisa FAPESP. 2017. 155 f. Dissertação (Mestrado)

- Escola de Comunicações e Artes, Universidade de São Paulo, 2017.

A dissertação tem como questão inicial o processo de comunicação entre instituições de pesquisa e a comunidade não científica, atentando para o papel mediador do designer gráfico. Recorreu-se a dois referenciais teóricos da Comunicação: o Design da Informação - no qual insere-se o estudo da infografia - e a Divulgação Científica. Foi também compilado um conjunto de soluções infográficas, buscando-se identificar aspectos que qualificam uma comunicação visual eficiente, investigando-se não apenas atributos estéticos, mas também de caráter cognitivo. Por fim, propôs-se um modelo de análise empírico para infográficos jornalísticos, que foi testado em corpus proveniente da revista Pesquisa FAPESP, publicação de Divulgação Científica editada pela Fundação de Amparo à Pesquisa do Estado de São Paulo. Os resultados gerados pelo modelo permitem visualizar as ênfases dadas, respectivamente, às seguintes funções de design: utilidade, precisão e satisfação; de forma que permita verificar a adequação do formato infográfico empregado ao conteúdo informativo - da reportagem - representado.

Palavras-chave: Design da informação; Divulgação científica; Infografia; Pesquisa FAPESP; Comunicação visual. 
SATO, S. N. Infographics in scientific popularization: a case study of Pesquisa FAPESP magazine. 2017. 155 p. Dissertation (Master's degree)

- Escola de Comunicações e Artes, Universidade de São Paulo, 2017.

The initial inquiry of the dissertation is the communication process between research institutions and the non-scientific community, observing the mediating role of the graphic designer. Thus, the approach to two major theoretical references: Information Design - in which infography is inserted - and Scientific Popularization. In addition, a set of infographic solutions was compiled to exemplify aspects that qualify efficient visual communication, in an investigation of both aesthetic and cognitive attributes. Finally, an empirical analysis model for journalistic infographics is proposed, which was tested with a corpus taken from the Scientific Popularization magazine Pesquisa FAPESP, published by São Paulo Research Foundation - FAPESP. The achieved results from the model allow the visualization of the emphasis given, respectively, to the following design functions: utility, precision and satisfaction. Hence, it enables to verify the adequacy of the employed infographic format to the informational content represented.

Keywords: Information design; Scientific popularization; Infographics; Pesquisa FAPESP; Visual communication. 


\section{Sumário INTRODUÇÃo}

Capítulo 1 DIVULGAR A CIÊNCIA

1.1 POR QUE DIVULGAR?

1.1.1 Como se comunica a ciência

1.1.2 Divulgação Científica como jornalismo

1.2 A REVISTA PESQUISA FAPESP

1.2.1 Histórico da Pesquisa FAPESP

Capítulo 2 INFORMAR PELO DESIGN

2.1 DESIGN DA INFORMAÇÃO

2.1.1 Origens da disciplina

2.1.2 0 documentador visual da ciência

2.2 O QUE É UM INFOGRÁFICO?

2.2.1 Texto e imagem

Capítulo 3 DESIGNHAR A INFORMAÇÃO

3.1 O PROCESSO COGNITIVO

3.2 PRINCÍPIOS E DIRETRIZES

3.2.1 Utilidade

3.2.1.1 Contextualização

3.2.1.2 Organização e conforto

3.2.2 Confiabilidade

3.2.2.1 Integridade gráfica

3.2.3 Satisfação

3.2.3.1 Atratividade

Capítulo 4 PROPOSTA DE ANÁLISE

4.1 AMOSTRAGEM

4.1.1 Recursos gráficos

4.1.2 As editorias

4.1.3 Classificação dos infográficos

4.2.1 Exemplo de aplicação 


\section{INTRODUÇÃO}

Os avanços logrados no âmbito da ciência parecem ocorrer num universo completamente apartado das preocupações cotidianas do cidadão comum. A pesquisa científica é praticada em prol de uma sociedade que a financia, mas esta mesma sociedade tem pouco conhecimento das descobertas e progressos que se realizam. Jargões técnicos, linguagem hermética e modelos intricados de comunicação agravam o distanciamento entre a ciência e um público mais amplo.

Como aproximar esses dois universos e assegurar ao cidadão o direito de ser bem informado sobre questões que impactam tão diretamente sua vida? Quais os formatos comunicacionais adequados? Poderia o recurso infográfico, tão em voga, contribuir para a atração e envolvimento da comunidade nas obscuras questões da ciência?

Tais indagações, somadas à minha atuação profissional como designer e chefe de seção na Assistência de Comunicação e Relações Institucionais da ECA-USP, impulsionaram a investigação dos temas aqui apresentados. Importante salientar que o processo foi enriquecido pelos direcionamentos da professora orientadora, ativa na linha de pesquisa Consumo e Usos Midiáticos nas Práticas Sociais e experiente no estudo do Design da Informação.

O formato infográfico foi eleito para análise mais aprofundada por aliar o caráter direto e engajador das representações imagéticas à descrição objetiva possibilitada pela linguagem verbal, o que suscitou numa incursão por dois referenciais teóricos basilares: o Design da Informação no qual insere-se o estudo da infografia - e a Divulgação Científica - campo de aplicação que se identifica, entre outras, com a prática jornalística. Os esforços do presente trabalho tiveram como objetivos:

a) A investigação do processo de comunicação entre instituições de pesquisa e a comunidade não científica, atentando para o papel mediador do designer gráfico. Interessava compreender o potencial comunicacional e democratizante da infografia na produção de conhecimento. 
b) A construção de um repertório teórico consistente, estabelecendo as bases conceituais para problematizar a infografia no âmbito do Design da Informação e da Divulgação Científica; e conduzindo a procedimentos metodológicos congruentes.

c) A construção de um repertório de soluções visuais que favorecem a assimilação de temas complexos. Em especial, desejava-se identificar aspectos que qualificam produtos gráficos eficientes, investigando não apenas atributos estéticos, mas também de caráter cognitivo.

d) A proposição de um protocolo de análise empírico para infográficos jornalísticos, que seria testado em um corpus associado à divulgação da ciência. A partir dos resultados, interessava investigar a relação entre determinadas composições estruturais (estratégias visuais) e categorias específicas de conteúdo textual.

0 processo investigativo não foi linear, envolvendo descobertas e suscitando câmbios, promovendo flexões e reflexões. Como formatação dos frutos da busca empreendida, estes foram organizados em cinco capítulos, conforme descritos a seguir.

0 primeiro capítulo traça breve panorama da Divulgação Cientííca, campo de aplicação imbuído por constante embate entre a necessidade de se manter a integridade dos conceitos originais e a "imperiosa exigência de se estabelecer efetivamente a comunicação" (BUENO, 2010, p.3). São também introduzidas concepções provenientes do jornalismo que norteiam, na esfera da Divulgação Científica, práticas de eficiência comunicativa.

Questões de democratização da ciência encontram ferramenta valiosa no design, devido à sua "capacidade de construir pontes e forjar relações num mundo cada vez mais esfacelado pela especialização e fragmentação de saberes" (CARDOSO, 2012, p.234). 0 Design da Informação, especificamente, é dedicado ao processamento, ordenação e apresentação eficiente de conjuntos de dados, motivo pelo qual a disciplina e seus conceitos fundamentais são explorados no Capítulo 2. Frisamos que as definições e delimitações em torno do Design da Informação e da infografia são ainda bastante inconsistentes e heterogêneas, o que demandou certa prudência no emprego de terminologias.

Ao passo que esse segundo capítulo concentra aspectos conceituais do Design da Informação, o Capítulo 3 é um estudo de caráter exploratório, investigando formas e estruturas que concretizam os fundamentos teóricos. Apresenta-se um compilado de infográficos, discorrendo-se sobre questões de eficiência em relação às três funções de design propostas por Mijksenaar (1997, p.18): utilidade, confiabilidade e satisfação. 
Durante o processo de investigação, deparamo-nos com uma revista de Divulgação Científica que sobressaía em relação aos demais exemplares nacionais pelo apuro gráfico e, sobretudo, pela produção infográfica clara, concisa e esteticamente atraente. Neste ponto, a revista Pesquisa FAPESP - editada pela Fundação de Amparo à Pesquisa do Estado de São Paulo com o objetivo de difundir e valorizar os resultados da produção científica e tecnológica brasileira - passou a ser objeto de análise específica.

Partindo da base teórica construída, o Capítulo 4 é dedicado a descrever o sistema de verificação de infográficos e o protocolo analítico aqui proposto. Num primeiro momento, fez-se uma avaliação global de todos os recursos gráficos empregados pela revista Pesquisa FAPESP durante um período estabelecido. Desta avaliação inicial, obteve-se o corpus, ao qual foi aplicado o modelo de análise. 0 modelo mensura as ênfases dadas às três funções infográficas perscrutadas previamente (utilidade, confiabilidade e satisfação), visando identificar a função prevalente em cada exemplar e averiguar sua adequação ao tipo de reportagem e ao conteúdo informativo. Baseado em critérios pré-determinados, o protocolo gera resultados quantitativos, o que possibilita avaliações objetivas dos inográficos analisados.

Por fim, nas Considerações Finais, retomam-se as conclusões aferidas, delineandose implicações e caminhos futuros. Dessa forma, o presente trabalho pretende colaborar para a pesquisa em Design da Informação e, a partir de uma abordagem sistemática, atestar a contribuição dessa disciplina para o exercício da comunicação social. Também objetiva-se fornecer ferramentas que otimizam a tomada de decisões semântico-sintáticas na produção infográfica para a Divulgação Científica. 
Capítulo 1

DIVULGAR A
CIÊNCIA 


\section{Capítulo 1 DIVULGAR A CIÊNCIA}

Em meados de 2015, uma comoção nacional em torno da fosfoetanolamina sintética (substância anunciada nas mídias sociais e por alguns veículos de comunicação como capaz de curar "o câncer"1), reacendeu a discussão acerca do distanciamento entre sociedade e instituições de pesquisa. Na ocasião, o Instituto de Química de São Carlos da Universidade de São Paulo - IQSC USP - tornara-se um ponto de "peregrinação" para familiares de pacientes oncológicos, esperançosos pela cura milagrosa supostamente descoberta no instituto. Não obtendo êxito ao pleitear doses da substância, alguns pronunciaram-se publicamente condenando a Universidade por lhes negar o direito ao tratamento. Em fevereiro de 2016, a Universidade de São Paulo já havia sido citada em mais de 13 mil processos movidos por pacientes que exigiam o fornecimento do composto (ESCOBAR, 2016a).

Existem ao menos dois equívocos nesse cenário, de alguma forma relacionados à comunicação:

\footnotetext{
1 É importante salientar que não existe um único tipo de câncer, mas diversas modalidades da doença, cada uma apresentando características específicas que devem ser tratadas de forma diferenciada. Seria, portanto, pouco provável que uma única substância fosse capaz de curar todos os tipos de câncer (IAMARINO, 2015b; LINCK, 2015; PIVETTA, 2016, p.23; SIMÕES, 2015).
} 
a) a fosfoetanolamina ainda não havia passado por todos os testes pré-clínicos (in vitro e com animais) e clínicos (com seres humanos), etapas essenciais para comprovar sua eficácia e para que se pudesse liberar seu uso como medicamento (BUSCATO et al, 2015; ESCOBAR, 2016b; IAMARINO, 2015b; IQSC, 2015; LINCK, 2015; LOPES, 2015; PIVETTA, 2016, p.20-21; SIMÕES, 2015; TESSLER, 2015; USP, 2015; VARELLA, 2015);

b) a Universidade de São Paulo é uma instituição dedicada à pesquisa, e não à produção e fornecimento de medicamentos, como uma indústria química ou farmacêutica (PIVETTA, 2016, p.23; SIMÕES, 2015; USP, 2015).

Na visão de alguns pesquisadores (ENGELKE, 2015; IAMARINO, 2015a; PIRULA, 2015; SIMÕES, 2015) equívocos como esses seriam, em parte, responsabilidade da própria comunidade científica, que não estaria suficientemente engajada em divulgar a ciência que desenvolve e em produzir material de divulgação em formatos e linguagem acessíveis à população. Tal cenário tenderia a suscitar a perda de confiança nas instituições de pesquisa, inclusive "dando margem para os sensacionalismos midiáticos" (ENGELKE, 2015).

0 fato é que a população brasileira tem pouco contato com informações científicas. 0 Centro de Gestão e Estudos Estratégicos - CGEE - e o Ministério da Ciência, Tecnologia e Inovação - MCTI -, realizaram, em 2015, a quarta edição da pesquisa Percepção Pública da Ciência e Tecnologia no Brasil, cujo objetivo foi levantar o "interesse, acesso à informação, conhecimento, bem como comportamentos, hábitos e atitudes dos brasileiros em relação à C\&T" (CGEE, 2015). Foram entrevistados 1.962 homens e mulheres com idade igual ou superior a 16 anos. 0 estudo detectou que $87 \%$ dos participantes não lembra o nome de uma instituição de pesquisa no país e $94 \%$ sequer consegue citar um pesquisador brasileiro. A maioria dos entrevistados se declarou interessada por ciência (61\%), mas o $8^{\circ}$ cientista "brasileiro" mais lembrado foi Albert Einstein.

No contexto internacional a situação não é tão diferente. Ciuccarelli (2012), do Politécnico de Milão, reconhece que, de forma geral, cientistas são percebidos como distantes e elitistas. Não à toa, ocasionalmente se deparam com oposição feroz, apesar da relevância de suas pesquisas. 0 diretor também concorda que esse distanciamento ocorre em parte porque os cientistas tendem a empregar uma linguagem muito "específica e frequentemente impenetrável", mesmo nas ocasiões em que “uma comunicação clara com o público é necessária” (CIUCCARELLI, 2012, p.79, tradução nossa).

Por outro lado, o caso da fosfoetanolamina sintética também parece sinalizar um aspecto positivo: a população brasileira confia na ciência e nos cientistas (ENGELKE, 2015; IAMARINO, 2015b; 
TESSLER, 2015). Isso pode ser verificado pelo fato de a notícia (ainda que equivocada) de uma cura resultante de pesquisa científica ter atraído a atenção e a confiança de tantas pessoas. Buscaram uma solução na ciência, ao invés de uma terapia alternativa, mística ou "picareta" (ENGELKE, 2015).

Um dos fatores aferidos pela pesquisa sobre Percepção Pública da Ciência e Tecnologia no Brasil (CGEE, 2015) foi justamente o Índice de Confiança (IC) que os brasileiros depositam nas informações fornecidas por profissionais de diversas categorias. 0 índice foi mensurado em graus que variavam de -1 a 1 . Constatou-se que os cientistas ligados a instituições públicas possuem o mais alto nível de confiança $(0,89)$, acima dos jornalistas $(0,74)$ e médicos $(0,7)$, e muito acima dos políticos $(-0,96)$. 0 estudo também demonstrou um ligeiro aumento da confiança nesses cientistas em relação à pesquisa anterior (em 2010 o índice era de 0,8).

Confiança esta posta ainda mais em evidência pelo constante apelo à legitimidade científica nas estratégias de vendas de produtos os mais variados: desde a marca de creme dental cuja embalagem inclui foto, nome e CRO de um dentista que "recomenda" o produto; até o brinquedo para bebês elaborado em "cooperação com o International Children's Medical Research Society"; ou a escola de informática cujo método de ensino foi “desenvolvido e aprovado por pesquisadores da USP".

0 momento, portanto, parece oportuno para que as instituições de pesquisa invistam no aprimoramento de sua comunicação com a população². A Pró-Reitoria de Pesquisa da Universidade de São Paulo promoveu, também em 2015, o Workshop Comunicação e Pesquisa, reunindo jornalistas e cientistas. 0 então superintendente de Comunicação Social da USP enfatizou a importância da Divulgação Científica: "veículos de comunicação têm um papel essencial para amplificar o conhecimento aqui produzido. Não é de nosso interesse que as pesquisas e o trabalho da Universidade fiquem restritos à comunidade interna" (ROLLEMBERG in JORNAL DA USP, 2015).

Marques, editor executivo da revista Pesquisa Fapesp, afirmou a participação do periódico nessa incumbência, ressaltando que os profissionais que o produzem estão empenhados em “transformar uma informação cifrada, bastante difícil para o público leigo, em algo minimamente inteligível" (MARQUES in JORNAL DA USP, 2015).

Em outra esfera, a do Currículo Lattes, a criação de uma aba na qual o pesquisador pode registrar atividades de Divulgação Científica (PIERRO, 2013, p.35), indica também uma valorização aos esforços pela aproximação entre ciência e sociedade.

\footnotetext{
2 No tocante à fosfoetanolamina sintética, em 2016 o MCTI lançou um site (www.mcti.gov.br/fosfoetanolamina) para divulgar informações sobre $o$ andamento das pesquisas com a substância.
} 


\section{1}

\section{POR QUE DIVULGAR?}

Compartilhamos a visão de Lamas et al (2007, p. 76) que identificam cinco razões pelas quais pesquisadores buscam estabelecer uma comunicação com audiências não especializadas:

a) Informar os cidadãos sobre o trabalho que é realizado com o dinheiro dos impostos que pagam (LAMAS et al,2007, p.76).

Em diversos países (como é o caso do Brasil) a verba destinada à pesquisa é primordialmente originária de financiamento público, o que confere aos cientistas a responsabilidade de notificarem à sociedade o destino dessas quantias, e torna o acesso a tais informações "um direito de todos" (FOSSEY, 2006, p.10). Neste cenário, a comunicação, "atividade tão intrínseca ao Homem [...] mais do que fazer sentido, [prova-se] uma necessidade premente" (MAGALHÃES, 2015, p.52); que é suprida pela divulgação científica, exercício através do qual os produtores da ciência “dão a conhecer o resultado do seu trabalho a destinatários não-especialistas" (FERNANDES, 2011, p.93).

b) Envolver os cidadãos em decisões de financiamento científico (LAMAS et al, 2007, p.76).

O contato das instituições de pesquisa com a imprensa torna-se "conveniente" (TUFFANI, 2003) ao promover visibilidade pública. Visibilidade esta que articula uma aproximação com a sociedade, ampliando a aprovação pública, gerando apoio político e atraindo financiamentos (CIUCCARELLI, 2012:79; MAGALHÃES, 2015, p.52).

Cenário notável é o atingido pela comunidade científica dos Estados Unidos da América, país em cuja opinião pública se tem cultivado já “há muitas décadas [um] forte sentimento favorável aos investimentos em C\&T" (MOURA, 1999, p.3). lamarino (2015a) cita o exemplo da NASA, a Agência Espacial Norte Americana, que logrou vasto reconhecimento e apoio popular em parte graças ao constante e eficiente relacionamento com a grande mídia. 
c) Envolver os cidadãos na atividade científica e torná-la mais familiar (LAMAS et al, 2007, p.76). Para além das necessidades sociais e políticas da divulgação científica, destacam-se a curiosidade e motivações individuais que impulsionam a produção do conhecimento:

\begin{abstract}
"Quando se fala de ciência nos jornais, revistas, etc., na maior parte das vezes aborda-se o aspecto muito importante da aplicação da ciência, de sua utilidade, de sua importância para a economia de um país, para o desenvolvimento econômico, social, o que é absolutamente correto, mas raramente fala-se sobre um outro lado que é o do desejo do homem de entender o universo. Essa é a parte lúdica da ciência, suas motivações originais e, depois, as emoções associadas com a ciência."

(MEIS in Pesquisa FAPESP, 2001, p.90)
\end{abstract}

Pretende-se "munir o cidadão" (AFONSO, 2008, p.23) de algum conhecimento científico, permitindo-lhe compreender e criticar a produção de pesquisa, e fornecendo-lhe ferramentas para "fazer face às suas escolhas individuais [moldando] o seu o hoje e o seu futuro" (AFONSO, 2008, p.21). Lawrence (2006, p.30-31) defende que essa abordagem com o público deve ser próxima e pessoal, citando o caso dos pesquisadores James Watson e Francis Crick que, em 1953, propuseram o modelo em dupla hélice para o DNA, solucionando debates correntes acerca desta estrutura:

“Enquanto Watson e Crick precisaram apenas de um artigo curto e seco na
Nature para cativar a comunidade científica, que por anos aguardava ansiosa-
mente a solução para o enigma do DNA e entendia perfeitamente o seu valor
(para a ciência, assim como para seus descobridores); para captar a aten-
ção do público foi necessário o Double Helix, um livro que recriou tudo o que
estava por trás da pesquisa, incluindo a urgência da 'perseguição louca' dos
dois jovens pesquisadores, pressionada pela concorrência de muitos e mais
qualificados colegas. Em outras palavras, era uma pessoa falando sobre isso." (LAWRENCE, 2006, p.30, tradução nossa)

d) Estabelecer a ciência como componente da cultura (LAMAS et al, 2007, p.76).

A ciência está "entrelaçada na nossa sociedade", mantendo uma complexa relação de reciprocidade (BARBEIRO, 2007, p.9) e gerando processos pelos quais a cultura científica e seu conhecimento "se incorporam à cultura comum" (BRYANT, 2003, p.357, tradução nossa). A atividade científica é, portanto, também uma atividade cultural, com características que concorrem para o "estabelecimento das relações críticas necessárias entre os cidadãos e os valores culturais de seu tempo e de sua história" (VOGT, 2006, p.25).

Para Moutinho (2006, p.62), a valorização da ciência e a solidificação de uma cultura científica dão origem ao "Homo Scientificus" (Figura 1). Durante o processo de "especiação societal", a ciência se "autonomiza da comunidade científica e da exploração associada à competitividade eco- 
nômica para se constituir como fator de cidadania", numa ontogenia que "reflete-se claramente na retórica associada aos programas públicos" (MOUTINHO, 2006, p.62).

\section{Figura 1. Homo Scientificus}

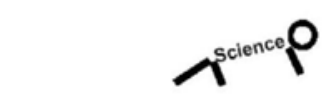

...is a matter

of scientists.

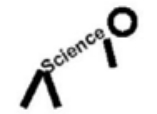

is a matter

of money.

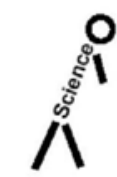

...matters!

Tradução das legendas: "A ciência é uma questão de cientistas."

"A ciência é uma questão de dinheiro." “A ciência importa." Fonte: Moutinho (2006, p. 62).

e) Inspirar os jovens a seguirem carreiras em ciência (LAMAS et al, 2007, p.76).

Segundo Fernandes (apud MAGALHÃES, 2015, p.54), a divulgação científica é tão importante quanto o fazer ciência, justamente por representar o principal meio pelo qual se despertam vocações científicas.

Por fim, os objetivos da divulgação da ciência, tal qual é vista na presente pesquisa, sumarizam-se em: a compreensão pública dos conteúdos científicos, dos métodos de investigação e da pesquisa enquanto atividade benéfica para os indivíduos e para a sociedade (MILLAR, 2003, p.150). 


\subsubsection{Como se comunica a ciência}

Aqui vale salientar que o fluxo comunicacional que se dá em torno da atividade científica, tecnológica e de inovação - CT\&l - desenvolve-se em uma gama de configurações bastante distintas. Além da comunicação com audiências leigas (domínio que interessa à presente dissertação), existe também a troca de informações, fortemente regimentada, que ocorre entre os próprios cientistas. Considerando-se os distintos públicos e modos de produção, é possível identificar duas categorias principais (Figura 2): a da Comunicação Científica, realizada entre pares, e a da Divulgação Científica, destinada a um público mais amplo (BUENO, 2010, p.2).

\section{Figura 2. Revistas de Comunicação Científica e de Divulgação Científica.}

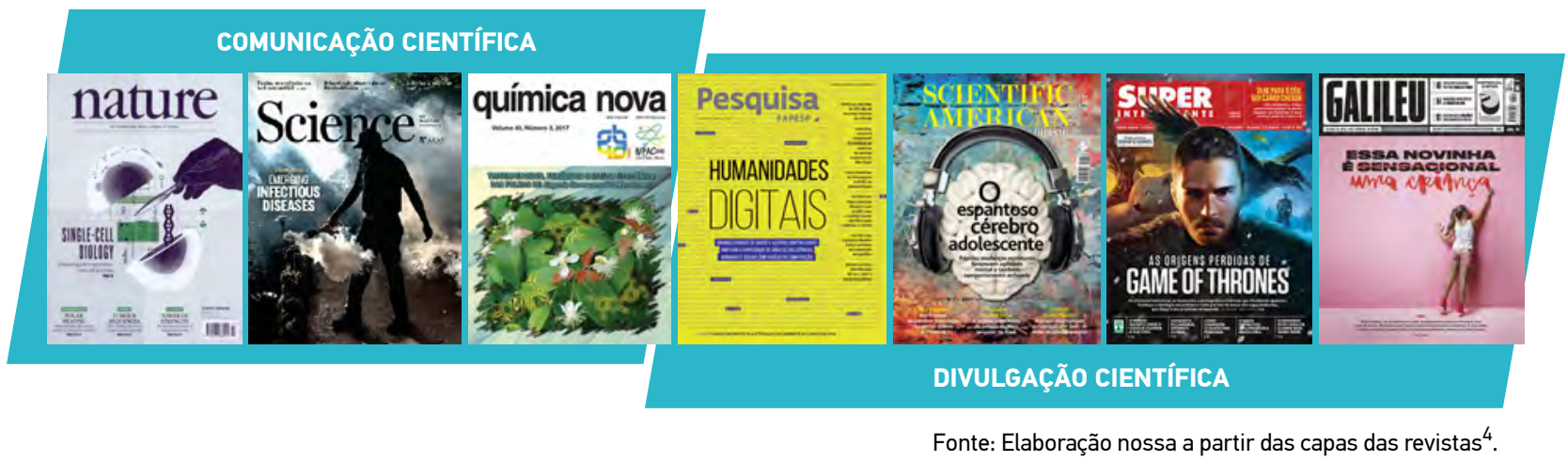

A Comunicação Científica é aquela restrita à comunidade de especialistas em determinado campo de estudo. Este "discurso científico primário" (CORACINI, 1991, p.57; FOSSEY, 2006, p.13) pressupõe uma audiência familiarizada com a matéria e os métodos empregados na área, o que permite a supressão de muitas informações que se fazem “supérfluas e desnecessárias" - como por exemplo, explicações metodológicas, de termos e fórmulas (CORACINI , 1991, p.57). Mas por ser transcrito em "códigos especializados, para um público seleto" (BUENO apud ALBAGLI, 1996:397), o discurso torna-se um tanto hermético para o leigo. Textos (e frequentemente imagens) são produzidos pelos próprios cientistas, tendo como objetivo central "persuadir da validade da pesquisa e

\footnotetext{
${ }^{3}$ Edições das revistas: Nature (v.547, n.7661, 6 jul. 2017); Science (v.357, n.6347, 14 jul. 2017); Química Nova (v.40, n.3, abr. 2017); Pesquisa FAPESP (n.255, mai. 2017); Scientific American (n.158, jul. 2015); Superinteressante (n.377, jul. 2017); Galileu (n.307, jun. 2016).
} 
do rigor científico da mesma" (CORACINI , 1991, p.57). Esta comunicação interpares ${ }^{4}$ concretiza-se $^{-1}$ em formas diversas, dentre as quais: conference proceedings, resumos submetidos a reuniões científicas, anais de congressos e papers publicados em revistas especializadas - como Nature, Science, Brazilian Journal of Biology, The Journal of Chemical Physics, Química Nova, entre outras - que seguem um formato rígido e pré-estabelecido por suas normas editoriais (FOSSEY, 2006, p.13).

Por outro lado, a Divulgação Científica - termo mais frequente na literatura para designar a popularização da ciência (ALBAGLI, 1996, p.397) - destina-se à "comunidade em geral" (MAGALHÃES, 2015, p.56), objetivando "democratizar o acesso ao conhecimento científico e estabelecer condições para a chamada alfabetização científica", pressupondo "temática sempre mais aberta [...] com perspectiva multidisciplinar" (BUENO, 2010, p.5). Nesta categoria percebe-se a presença do mediador: o jornalista que escreve as reportagens; os fotógrafos, ilustradores e infografistas que produzem as imagens. A esfera de circulação também se expande, adentrando as livrarias, bancas de jornal ou os próprios jornais: ao âmbito da Divulgação Científica nacional pertencem, por exemplo, as editorias de ciência da Folha de S. Paulo e O Estado de S. Paulo, assim como as revistas Superinteressante, Galileu, Scientific American Brasil, National Geographic Brasil, INPA: ciência para todos, Unesp Ciência e Pesquisa FAPESP.

Mas ambas as categorias também envolvem nuances e gradações, gerando suas próprias ramificações. Na comunicação interpares, Zamboni (2001, p.35-37) admite quatro subcategorias, caracterizadas conforme uma escala que varia de altamente especializada a menos especializada. Na divulgação extrapares, a distinção se faz pelas variadas posições editoriais, audiências, temáticas e níveis de discurso (BUENO, 2010, p.9). Veículos ligados a instituições de pesquisa, como por exemplo a Pesquisa FAPESP, mantêm forte ligação com os próprios cientistas e atingem públicos mais familiarizados com conteúdos de CT\&I. Do outro lado do gradiente, estão veículos de natureza mais comercial, como a Superinteressante - quarta revista mais vendida no país (SILVA, 2016) - ou Galileu, que visam um leitor mais jovem e menos comprometido com o rigor científico. (Trataremos destas especificidades mais adiante.)

\footnotetext{
${ }^{4}$ Bueno (2010, p.9) emprega o termo intrapares para se referir à comunicação "entre especialistas de um campo ou de campos conexos". Mas adotamos aqui o termo interpares por entender que o prefixo inter exprime mais adequadamente algo que ocorre entre duas ou mais partes; ao passo que o prefixo intra indicaria um fato interno a uma única unidade.
} 


\subsubsection{Divulgação Científica como jornalismo}

À parte de suas subdivisões, é possível afirmar que os formatos comunicacionais da Divulgação Científica extrapares identificam-se, em muitos aspectos, com o campo do jornalismo (FOSSEY, 2006, p.8).

Bueno (2010, p.4), no entanto, defende que não se deve confundir a Divulgação Científica com o gênero mais específico do "jornalismo científico", por aquela primeira ser mais abrangente e extrapolar "o território da mídia". Mas na presente dissertação trataremos de algumas características da Divulgação Cientííca que a aproximam da prática jornalística, independente das diferentes classificações e taxonomias existentes.

Assim como a comunicação jornalística, que é tida como "referencial" por relatar "algo no mundo, exterior ao emissor, ao receptor e ao processo de comunicação em si" (LAGE, 1985, p.39), a Divulgação Científica também exprime, na presença mediadora do jornalista (ou fotógrafo, ilustrador ou infografista) essa prática referencial. Estudos contemporâneos sobre jornalismo vêm identificando que, além da função referencial, o fazer jornalístico assume também uma "função pragmática" ao contextualizar fatos e agentes, "categorizar, descrever e manifestar estruturas dos acontecimentos do mundo" (GIANNELLA, 2014, p.54); movimento também identificado na divulgação de ciência.

Por sua proximidade com o campo do jornalismo, a Divulgação Científica é frequentemente regida por códigos específicos deste meio, admitindo, por exemplo, gêneros como editoriais, cartas de leitores, notas e reportagens (FOSSEY, 2006, p.46), diferenciando-a novamente da comunicação científica específica interpares.

Outro aspecto jornalístico que permeia a Divulgação Científica é o intuito de "contar novidades”, característica que a distingue do campo didático: “No ensino, não se tem como quesito básico o fato de se falar sobre as novidades do campo científico, mas sim ensinar sobre fundamentos de uma dada disciplina" (FOSSEY, 2006, p.46). Embora conhecimentos já estabelecidos, "enciclopédicos" (SILVEIRA, 2010, p.81), eventualmente logrem espaço em publicações de Divulgação Científica, não são estes o foco de tais veículos.

Alguns autores (ALBAGLI, 1996, p.397; AUTHIER-REVUZ, 1998, p.108) entendem essa divulgação extrapares como um trabalho de "tradução", de uma linguagem especializada para uma leiga. Seus produtos seriam resultado de reformulação textual-discursiva que parte do discurso 
científico primário - a comunicação interpares, realizada na "língua" dos cientistas - para a "língua" do grande público (AUTHIER-REVUZ, 1998, p.108).

Zamboni (2001, p.50-79) e Fossey (2006, p.41-43) confrontam tal posicionamento, por manter a Divulgação Científica "incomodamente vinculada" ao discurso científico primário. Ao se supor a mera reformulação de um discurso preexistente em função do novo público, a divulgação extrapares passa a "ocupar um papel subordinado" à comunicação interpares, sem que se reconheça a "autonomia e a especificidade desta atividade" (FOSSEY, 2006, p.42):

"Vejo na divulgação muito mais o trabalho de formulação de um novo discurso, que se articula, sim, com o campo científico - e o faz sob variadas formas - mas que não emerge dessa interferência como o produto de uma mera reformulação de linguagem. [...] Contrariamente a esse modo de ver, vejo no discurso de divulgação cientifica um gênero discursivo particular [...] autônomo tanto qualquer outro discurso possa ser"

(ZAMBONI, 2001, p.xvii-xviii, grifo da autora)

Ambas as autoras concordam que a autonomia deve-se ao fato de que a distinção entre a Comunicação Científica interpares e a Divulgação Científica extrapares não reside apenas nos públicos a que se destinam, mas também nas diferentes esferas sociais de circulação e circunstâncias de produção. Desta forma, "alterando-se os lugares dos protagonistas da cena enunciativa, restam alteradas todas as demais configurações do cenário" (ZAMBONI, 2001, p.62): o canal da comunicação, o tratamento das temáticas, o estilo de linguagem empregada e o formato do texto-produto. 


\section{2}

\section{A REVISTA PESQUISA FAPESP}

A FAPESP - Fundação de Amparo à Pesquisa do Estado de São Paulo - é uma das principais agências de fomento à pesquisa do país, financiando a investigação, o intercâmbio e a divulgação da ciência e da tecnologia produzida em São Paulo (FAPESP, 2017).

Lançada em 1999, a revista Pesquisa FAPESP é mensal e seu conteúdo é publicado tanto na versão impressa quanto pelo site www.revistapesquisa.fapesp.br. Pelo endereço eletrônico podem também ser visualizados vídeos e galerias de fotos que não estão disponíveis na edição física da revista. Analisamos aqui apenas os infográficos que são publicados em ambos os suportes (digital e impresso), portanto somente imagens estáticas e não interativas.

Cinco fatores principais determinaram a escolha da Pesquisa FAPESP como objeto para a presente pesquisa:

\section{a) natureza da revista:}

É uma publicação brasileira, destinada à divulgação da produção científica nacional, temática que consideramos de significativa relevância social. Investigá-la seria uma forma de contribuir para a melhor difusão dos avanços da ciência e de suas possíveis aplicações dentre parcelas mais abrangentes da população.

\section{b) relevância no campo de atuação:}

Por tratar-se de uma das únicas publicações jornalísticas especializadas na divulgação de ciência e tecnologia com foco na produção nacional, a Pesquisa FAPESP atua como um "polo de contato e reconhecimento contínuo dos pesquisadores brasileiros" e como "referência indispensável para as editorias de ciência e tecnologia dos veículos de comunicação nacionais" (Pesquisa FAPESP, 2017). 


\section{c) disponibilidade:}

A publicação, que tem uma tiragem de 23.900 exemplares, é enviada para uma "seleta carteira de assinantes subsidiados composta de pesquisadores" (Pesquisa FAPESP, 2017), além de contar com assinaturas pagas e ser comercializada em bancas de jornal. Ademais, em seu endereço eletrônico, a íntegra de todos os textos publicados está disponível de forma aberta e gratuita.

Ressaltamos que, apesar de o conteúdo da revista ser disponibilizado gratuitamente, não é possível afirmar que a Pesquisa FAPESP seja acessada por um público heterogêneo. Em 2011, o Instituto Datafolha realizou uma pesquisa com 858 leitores da versão impressa da publicação, entre assinantes pagos, assinantes cortesia e compradores em banca (MARCOLIN, 2011, p.38). 0 estudo revelou uma audiência bastante restrita, com alto nível de escolaridade (79\% têm pós-graduação) e elevado poder aquisitivo (renda média familiar de $\mathrm{R} \$ 11 \mathrm{mil}$ ).

Por outro lado, também verificou-se que $58 \%$ dos leitores são professores ou educadores; portanto é possível que o conteúdo da revista esteja atingindo a outras camadas da população de forma indireta. No decorrer de nossa pesquisa, esta hipótese foi reforçada: em conversa com a gerente de marketing e divulgação da Pesquisa FAPESP, soubemos que sua equipe é frequentemente contatada por editoras de livros didáticos cujo intuito é a aquisição de imagens (infográficos e fotografias) publicadas pela revista ${ }^{5}$. Os infográficos são reproduzidos, em sua maioria, em livros destinados ao Ensino Médio e aos $7^{\circ}$ e $8^{\circ}$ anos do Ensino Fundamental.

\section{d) acessibilidade:}

Clareza e objetividade caracterizam a linguagem empregada pela publicação. Segundo o levantamento realizado pelo Instituto Datafolha, $90 \%$ dos leitores consideram que os textos são de fácil leitura (MARCOLIN, 2011, p.38), o que condiz com a proposta da Divulgação Científica.

As temáticas abordadas também são acessíveis e agradam de um modo geral: 34\% dos entrevistados apontou, espontaneamente, a diversidade de assuntos como um motivo pelo qual costumam ler a revista, e 99\% a avaliam como altamente satisfatória (MARCOLIN, 2011, p.38). Alguns cientistas que participaram da pesquisa do Instituto Datafolha revelaram que leem a Pesquisa FAPESP para se informarem sobre assuntos de áreas que não sejam de seu próprio campo de estudo: “É o tal ócio produtivo, espécie de lazer que também informa” (apud MARCOLIN, 2011, p.40).

\footnotetext{
${ }^{5}$ Dentre as editoras que adquiriram conteúdo publicado pela Pesquisa FAPESP estão: Ática, FTD, Moderna, Pearson, Saraiva Educação, Scipione e Senai.
} 


\title{
e) apresentação gráfica:
}

Percebe-se que existe um certo esmero quanto ao projeto gráfico da revista. A diagramação das páginas e tratamento tipográfico são apurados, enquanto o estilo imagético acompanha tendências estéticas. Infográficos são utilizados com alguma frequência e costumam ser formatados com clareza e objetividade. Ilustrações e diagramas são elaborados por profissionais de comunicação visual (infografistas e estúdios de ilustração), não sendo apenas reproduções de imagens técnicas provenientes da comunicação científica entre pares.

Machado (2016, p.134) exprime bem como a Pesquisa FAPESP tem se tornado referência em sua área de atuação por conta, em parte, dos direcionamentos e esforços gráficos:

\begin{abstract}
“Tal publicação periódica se instalou no espaço público de comunicação de ciência com uma firme consciência de meio de comunicação afinada com os desígnios da linguagem gráfica nos meios impressos, o que a dignificou como objeto-fonte de referência para o estudo da comunicação da ciência naquilo que ela desenvolve de mais específico: a transformação do experimento e da informação científica em texto de comunicação. Para isso, o projeto editorial aliou-se a um projeto gráfico comprometido com a construção de uma textualidade duplamente modelizada pelos recursos gráficos dos meios impressos e também pelas ferramentas da própria ciência." （MACHADO, 2016, p.134)
\end{abstract}

Apresentamos a seguir um exemplo de infográfico publicado pela Pesquisa FAPESP. A imagem acompanha a reportagem Nas redondezas de outros mundos, da edição no 191 (jan/2012). 0 texto explica alguns métodos adotados por astrofísicos teóricos para observar a movimentação e características de exoplanetas (planetas que orbitam outras estrelas, que não o Sol). Não é possível

Figura 3. Infográfico da matéria Nas redondezas de outros mundos.

\section{Curva de luz indica tipo de planeta}
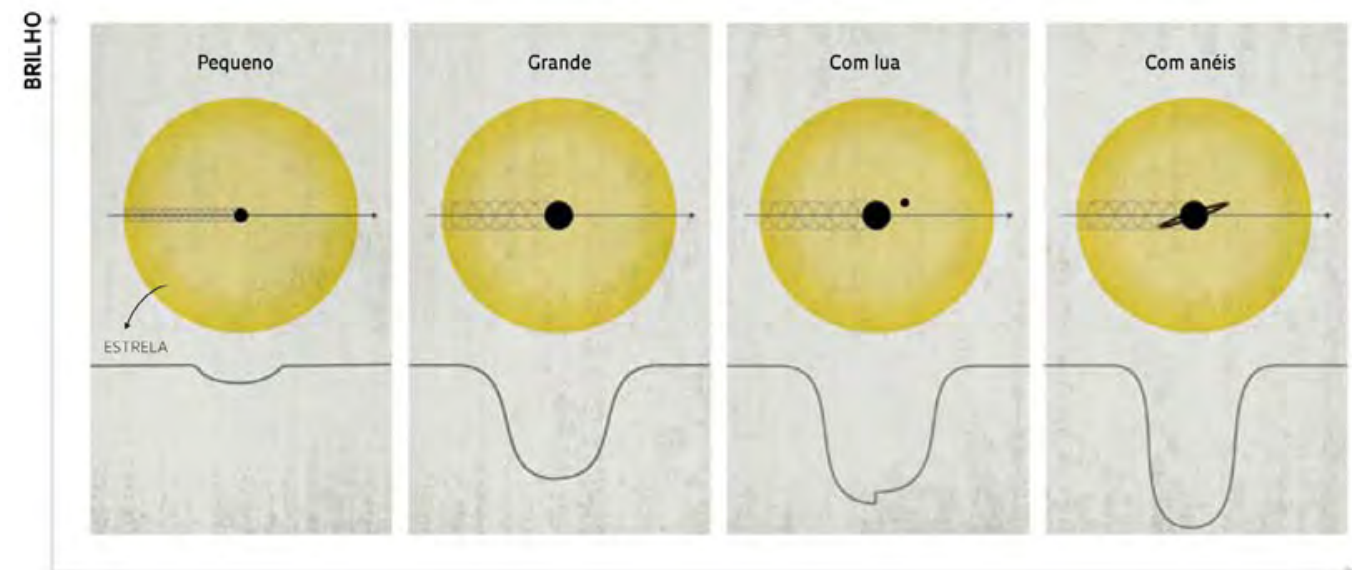

Ilustração de: DRÜM. Fonte: ZOLNERKEVIC, 2012. 
observá-los de forma direta, como por exemplo por fotos de satélites. Torna-se então necessário adotar técnicas indiretas, como o método do trânsito planetário, que registra a diminuição de brilho causada pela passagem de um objeto celeste na frente de sua estrela.

Nas quatro situações ilustradas no infográfico da Figura 3, a luminosidade, representada pela linha abaixo da estrela, diminui quando um planeta passa à sua frente (criando uma curvatura descendente na linha). Planetas grandes (segundo quadro) produzem curvas maiores que os pequenos. No terceiro quadro, a existência de uma lua provoca a formação de um 'degrau' na curva no momento em que o satélite posiciona-se à frente (ou atrás) do planeta. Já no último quadro, os anéis suavizam as bordas do 'poço' da curva de luz, tornando-o mais fundo. Dessa forma, a imagem complementa o texto, enriquecendo a assimilação do conteúdo informativo, mas de forma objetiva e acessível.

A título de comparação, reproduzimos na Figura 4 o gráfico proveniente de um paper publicado em periódico científico, também referente ao método do trânsito planetário. Por tratar-se de um produto da Comunicação Científica entre pares, a imagem é muito mais complexa, reunindo grande volume de dados que permitem ao especialista analisar as medidas fotométricas do fluxo luminoso representadas por 16.620 pontos.

Já no infográfico publicado pela Pesquisa FAPESP (Figura 3), a quantidade de informações foi reduzida e a estrutura foi readaptada, mantendo-se apenas os dados essenciais para a compreensão por parte do público leigo.

Salientamos aqui que o intuito da Divulgação Científica é servir como um primeiro contato com os conteúdo tratados, permitindo ao leitor, conforme seu interesse, aprofundar-se no assunto por outras fontes. Tal possibilidade é aberta pela Pesquisa FAPESP ao fornecer, na quase totalidade de suas matérias, as referências completas das pesquisas consultadas.

\section{Figura 4. Imagem relativa ao trânsito planetário, proveniente de periódico científico.}
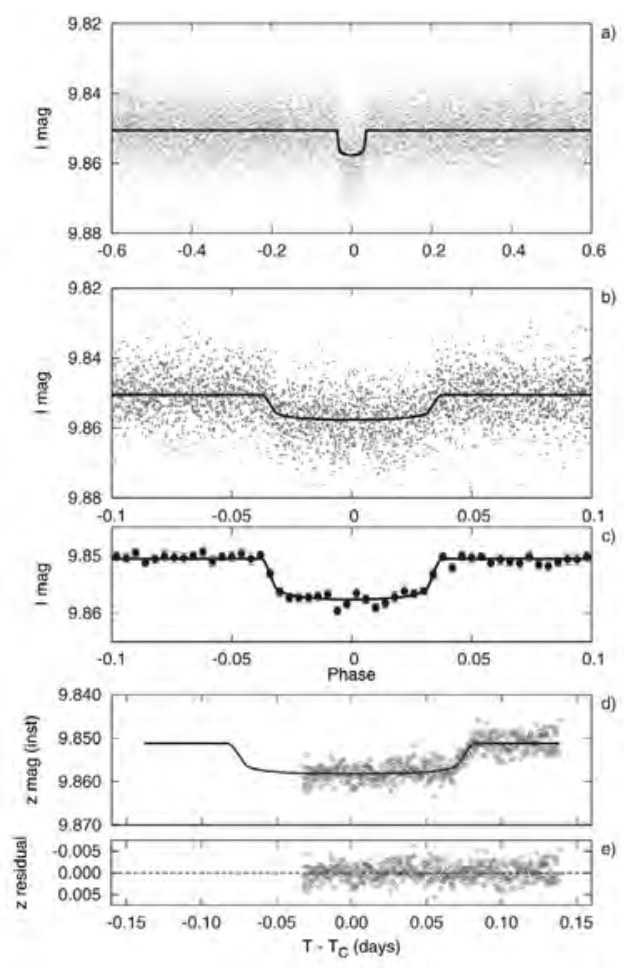

Fonte: PÁL et al (2008, p.1451). 


\subsubsection{Histórico da Pesquisa FAPESP}

A revista é resultado da evolução editorial de um informativo lançado em agosto de 1995. Inicialmente intitulado Notícias FAPESP, o boletim tratava principalmente de temas internos à própria FAPESP ou de políticas reguladoras da pesquisa, atingindo, portanto, um público bastante restrito. A distribuição era gratuita e destinada a pesquisadores paulistas, gestores da política nacional de ciência e tecnologia, além de jornalistas (Pesquisa FAPESP, 2017). A partir da sexta edição (fev/1996), na qual entraram duas matérias relativas a Ciência, novas temáticas foram sendo incorporadas, suscitando temas que não apenas aqueles concernentes ao funcionamento da instituição. Na edição $n^{\circ} 7$ (mar/1996) foi publicada a primeira reportagem relativa a Tecnologia; enquanto a matéria inaugural de Humanidades surgiu no primeiro aniversário da publicação, em sua edição nº $12($ ago/1996).

Na medida em que o formato de boletim abria espaço para matérias que relatavam resultados de pesquisas, a revista caracterizava-se gradualmente como uma publicação de Divulgação Científica. Mas esse enfoque original, dirigido primordialmente àqueles ligados a atividades de pesquisa, mantém-se ainda presente, embora de modo diluído.

Na edição no 47 (out/1999), a publicação tornou-se revista, passando a ser intitulada Pesquisa FAPESP. Pouco mais de dois anos depois, em sua 73a edição (mar/2002), a revista passou a contar com assinaturas pagas, a receber publicidade e a ser comercializada em bancas de jornal. $\mathrm{Na}$ nova etapa, a revista pretendia abrir-se "a todo leitor que queira saber a quantas anda realmente, neste país, o par Ciência e Tecnologia" (Pesquisa FAPESP, 2002, p.5), conforme declarado no Editorial daquele mês:

\begin{abstract}
“De uma publicação de circulação dirigida aos pesquisadores do Estado de São Paulo [...], aos editores de ciência e tecnologia da mídia nacional e aos formuladores e gestores das políticas de ciência e tecnologia de todo o país, passamos agora à condição de uma revista de circulação ampla e aberta a todo leitor que se interesse por ciência e tecnologia, e especialmente pelo que se passa em seus domínios no Brasil. Uma revista acessível a todos que queiram acompanhar de forma sistemática os resultados, muitas vezes fascinantes, dos mais importantes projetos de pesquisa em curso em São Paulo e no país [...]; que desejem compreender seus impactos científicos, sociais e econômicos; que queiram conhecer os programas e as políticas estaduais e nacionais voltados para o desenvolvimento científico e tecnológico no país."
\end{abstract}

(Pesquisa FAPESP, 2002, p.5) 
Para Fossey (2006, p.30), este novo modelo comercial representa o "passo final de consolidação da revista como uma publicação de [Divulgação Científica] voltado para o grande público - ou pelo menos para um público mais amplo do que o inicial".

A autora defende que, apesar de tornar-se uma "publicação interessante" inclusive para leitores desvinculados à Fapesp, o discurso da revista manteve-se fortemente influenciado por sua função “justificadora” e "auto-descritiva”, posto que "não se trata de uma publicação de [Divulgação Científica] qualquer, mas de uma revista que deriva diretamente de uma agência que atua no cenário da prática científica nacional" e que vincula "boa parte de seu conteúdo" à produção financiada pela própria fundação (FOSSEY, 2006, p.30-34). Em 2006, a autora analisou o conteúdo de três editorias da revista (Ciência, Tecnologia e Humanidades), concluindo que, dentre sua amostra de reportagens de 1999 a 2005, 65,8\% eram relatos de pesquisas que contavam com financiamento da FAPESP. Já na observação de edições apenas de 2005, o índice foi reduzido para $43,8 \%$.

Dez anos mais tarde, Machado (2016, p.134) reconhece que a Pesquisa FAPESP se "dignificou" como transformadora "do experimento e da informação científica em texto de comunicação", contribuindo para o acesso ao discurso científico:

\footnotetext{
"A revista Pesquisa FAPESP consagrou a formação discursiva que oferece a prosa cientíica como ensaio o que, no contexto do processo de prosificação da cultura, significa interação com os meios e processos desenvolvidos no espaço público da comunicação social mais ampla, tornada, por conseguinte, condição de seu desenvolvimento, tanto do ponto de vista da publicação quanto da compreensão. Reconhecer-se como espaço público implica abrir diálogo com a sociedade (que excede a comunidade científica) e, com isso, buscar fórmulas de interação discursiva em diferentes esferas."
}

(MACHADO, 2016, p.134)

Um dos diferenciais da Pesquisa FAPESP é a proximidade com os pesquisadores, que frequentemente colaboram na construção das matérias, inclusive verificando os textos (e eventuais produções visuais) antes de serem veiculados. Nas palavras de Marques, editor executivo da publicação, os cientistas "gostam muito da revista, confiam no nosso trabalho e isso facilita muito" (MARQUES in JORNAL DA USP, 2015).

Ao permitir que o enunciador principal seja o próprio pesquisador, a revista promove um certo "apagamento" do jornalista; diferentemente do que ocorre em revistas como a Superinteressante, nas quais "marca-se incessantemente um lugar para o jornalista e outro para os cientistas" (FOSSEY, 2006, p.90), dando indícios de um distanciamento maior em relação às instituições de pesquisa. 
Também reflexo da proximidade com os pesquisadores, é o detalhamento rigoroso dos estudos referidos. Na maioria das reportagens da Pesquisa FAPESP, são fornecidas informações relevantes sob a ótica das práticas científicas, como os nomes dos pesquisadores envolvidos, suas instituições de origem, os métodos utilizados nos experimentos e as agências financiadoras. Pelo grau de detalhamento, as reportagens geralmente enfocam e destrincham um único aspecto dentro de cada temática. Contrapondo-se novamente a Pesquisa FAPESP com a Superinteressante, percebe-se que:

\begin{abstract}
“Enquanto a primeira caracteriza-se por este movimento de circunscrição de um espaço de atuação, a segunda se caracteriza pelo movimento de generalização. Por exemplo, enquanto na Superinteressante lemos uma reportagem sobre como nasceu a teoria do caos, na Pesquisa Fapesp lemos sobre uma pesquisa que está sendo desenvolvida na USP de São Paulo por um pesquisador que utiliza a teoria do caos para tentar explicar a proliferação de espécies de plâncton."

(FOSSEY, 2006, p.103-104, grifos da autora)
\end{abstract}

Tal posicionamento também reflete o público da Pesquisa FAPESP, bastante distinto de outras revistas de divulgação cuja audiência não esta inserida na comunidade científica. Como citado anteriormente, o estudo realizado pelo Instituto Datafolha indicou que $79 \%$ dos leitores da Pesquisa FAPESP são pós-graduados (MARCOLIN, 2011, p.38). É possível inferir, portanto, que seus leitores sejam habituados as temas de cunho científico, mesmo que não estejam associados a uma área de conhecimento específica.

Mas isto não isenta a revista de tratar dos temas com uma linguagem objetiva e acessível. Entendendo que a principal qualidade da linguagem jornalística é a de buscar eficiência na comunicação, Lage (1985, p.36 - 38) propõe que as formas lexicais que os jornalistas devem privilegiar estariam em algum ponto entre o formal - condição para que o texto seja aceito, sofrendo interdições da norma culta - e o coloquial - condição para que o texto seja mais amplamente entendido, conforme interesses de comunicação.

Apesar da proximidade com a comunidade científica, um dos aspectos que reforça o compromisso com a democratização do conhecimento da Pesquisa FAPESP são as formas lexicais mais coloquiais e próximas ao leitor, como as listadas a seguir:

"A medida [...] foi tomada a despeito de não ter sido publicado um único trabalho científico sobre a segurança e os alegados efeitos positivos da fosfoetanolamina em seres humanos, passando por cima das prerrogativas da Anvisa." edição n² 243 (mai/2016), p.20 (grifo nosso) 
"Mas sua história é peculiar, com lances heterodoxos, e o composto se encontra em uma situação juridicamente inusitada [...]."

edição n 243 (mai/2016), p.20 (grifo nosso)

“Um grupo de médicos e epidemiologistas [...] suspeita que a estratégia de considerar quem nasce com crânio menor que $32 \mathrm{~cm}$ um potencial caso de microcefalia está incluindo no pacote muitos bebês que são saudáveis."

edição no 241 (mar/2016), p.18 (grifo nosso)

“O peso-médio nos calcanhares da [estrela] Mu Arae agradou à plateia e jogou os oponentes [...] contra as cordas. Menos de uma semana mais tarde [...] duas equipes independentes de pesquisadores dos Estados Unidos contragolpearam." [texto sobre descobertas no campo da astrofísica] edição no 104 (out/2004), p.44 (grifo nosso)

Outra evidência desse compromisso democratizante assumido pela Pesquisa FAPESP é o frequente emprego de infográficos bastante atraentes visualmente e acessíveis em termos de conteúdo informativo.

\section{3 \\ MACROSCÓPIOS}

O formato infográfico é enfocado na presente pesquisa justamente por permitir a apresentação clara, didática e objetiva de conteúdos intricados - o escopo da própria Divulgação Científica. Não à toa, frequentemente enfatiza-se a importância de pesquisadores e cientistas "associarem-se a designers, para representar os dados na linguagem das pessoas, e não na linguagem dos dados" (CIUCCARELLI, 2012, p.82, tradução nossa).

Ciuccarelli é diretor científico do DensityDesign, laboratório de pesquisa no departamento de design do Politécnico de Milão, cujo objetivo é criar representações visuais de sistemas complexos. Explorando o potencial da disciplina conhecida como Design da Informação, desenvolvem 
"artefatos visuais inovadores e envolventes" que facilitam a descrição e argumentação por parte dos cientistas: "uma espécie de atalho gráfico" (DENSITY DESIGN, 2017, tradução nossa).

No laboratório, os pesquisadores adotam o termo "macroscópios visuais" (CIUCCARELLI, 2012, p.80) como referência a De Rosnay (1979), que idealizou um instrumento simbólico composto por uma série de métodos e técnicas que conduzissem a uma abordagem global diante de determinada questão, filtrando detalhes e amplificando as conexões. Este instrumento seria o "macroscópio"b (de macro, grande, e skopein, observar); permitindo enxergar não o infinitamente pequeno ou o infinitamente distante (como fazem microscópios e telescópios), mas o infinitamente complexo. Seria utilizado para "observar aquilo que é ao mesmo tempo grande demais, lento demais e complexo demais para os nossos olhos (a sociedade humana, por exemplo, é um organismo gigantesco que é totalmente invisível para nós)" (DE ROSNAY, 1979, p.xiii-xv, tradução nossa).

Os "atalhos gráficos" de Ciuccarelli encontram correspondência nos infográficos publicados pela Pesquisa FAPESP como apoio visual ao processo de comunicação dos conteúdos informativos. Nosso objeto de interesse encontra-se justamente nesta intersecção entre os propósitos da Divulgação Científica e o potencial do Design da Informação, campo de estudo que esmiuçaremos a seguir.

\footnotetext{
${ }^{6}$ Salientamos que, apesar de ser tratado aqui como um neologismo, o termo "macroscopia" é empregado no meio médico em referência a exames clínicos que são realizados a olho nu (PORTO, 2017), sem a necessidade de instrumentos de ampliação de imagens.
} 
Capítulo 2

INFORMAR

PELO DESIGN 


\section{Capítulo 2 INFORMAR PELO DESIGN}

Em artigo recentemente publicado na revista Nature (NATTERER et al, 2017) uma equipe de pesquisadores ligados à IBM anunciou que desenvolveu uma técnica que permite armazenar um bit de informação em um único átomo. Atualmente, um disco rígido precisa de quase 100 mil átomos para realizar a mesma gravação. Isto significa que com a nova técnica, em tese, possivelmente conseguiríamos armazenar todo o catálogo do iTunes (cerca de 35 milhões de músicas) em um pequeno disco do tamanho de um cartão de crédito (BISWAL, 2017).

Apesar de serem ainda necessárias “décadas de pesquisa e trabalho de engenharia” até que este armazenamento de nível atômico esteja acessível ao público (MELLOR, 2017, tradução nossa), a notícia foi publicada nos principais veículos de comunicação mundo afora. 0 impacto midiático de pesquisas como essa refletem a atual necessidade por soluções de armazenamento para a exponencialmente crescente quantidade dados produzidos globalmente: mais dados foram gerados nos últimos dois anos do que em toda a história (SERVICE, 2017). 
0 problema do armazenamento de informações, no entanto, não é tão recente. Há mais de trinta anos, Crichton (1983, p.73) já escrevia que éramos "bombardeados com fatos demais - bits de dados isolados e sem contexto". Treze anos mais tarde, Schudson anteviu um mundo no qual cidadãos acessariam qualquer fonte de informação que desejassem pelas redes de computador: "Eles também enviam suas próprias informações e seus próprios comentários; eles são tão facilmente disseminadores quanto receptores da notícia". Devido ao volume de dados "as pessoas iriam querer [...] ajuda na interpretação e explicação dos eventos" (SCHUDSON, 1996, p.1-2, tradução nossa).

Ambos antecipavam o que hoje se tornou realidade: a quantidade de informação à disposição gera confusão e dúvida - seja quanto à veracidade dos dados e à confiabilidade da fonte; seja quanto à relevância de uma notícia ou àquilo que a informação realmente significa. Tal sensação de incerteza suscita aquilo que Wurman (1991, p.38) denominou de "ansiedade de informação": o resultado da distância cada vez maior entre o que compreendemos e o que achamos que deveríamos compreender. A função do designer da informação seria amenizar tal ansiedade, ajudando o receptor a "discernir o essencial do secundário" (SALAVERRÍA e SANCHO, 2007, p.229-230) e orientando-o na compreensão da mensagem.

Esse designer deve ter com clareza a distinção entre informação e dados: enquanto dados não passam de fatos brutos, a informação consiste no sentido que os seres humanos lhes atribuem. E a visualização é ferramenta valiosa para esse processo informativo. Como apontado por Farias (2014), a origem etimológica do termo informação remonta ao latim informare, cujo significado seria, entre outros, “dar forma a". Quando tornamos algo visível, estamos organizando elementos visuais para que deem forma àquilo que até então era invisível. Neste sentido, podemos dizer que a visualização "é o que permite que dados, que de outra forma seriam incompreensíveis, transformem-se em 'informação' propriamente dita, compreensível e compartilhável” (FARIAS, 2014). A disciplina que investiga os processos pelos quais dados são tranformados em informação e então comunicados a determinado público é o Design da Informação. 


\section{1}

\section{DESIGN DA INFORMAÇÃO}

A expressão Design da Informação é foco de muita discussão terminológica e enquanto alguns autores questionam se existe de fato uma prática que poderia levar este título ${ }^{7}$, mesmo aqueles que concordam com a expressão encontram dificuldade em estabelecer um enunciado preciso. Foi, inclusive, somente nas últimas décadas ${ }^{8}$ que se observou uma popularização (CAIRO, 2013, p.14; PASSINI, 2000, p.83; RENDGEN, 2012, p.9) e sistematização mais consistente (JACOBSON, 2000, p.2; MAZUR, 2003, p.24; WALLER, 2008, p.1; WINKLER, 2011, p.57) da disciplina.

Pode-se entendê-la como a "definição, planejamento e organização do conteúdo de uma mensagem e dos contextos em que é apresentada, com a intenção de satisfazer as necessidades de informação dos destinatários" (IIID, 2007, p.8). Os designers da informação procuram analisar profundamente os usuários da informação e as circunstâncias em que esta é transmitida, aplicando princípios tradicionais do design em busca de soluções de projeto adequadas às demandas específicas. 0 objetivo vai além da mera exposição de dados, implicando na eficiente comunicação do conteúdo informativo. Isso se dá através do processamento sistematizado e da apresentação clara de dados ou conceitos complexos, de forma tal que facilite a percepção, assimilação, retenção e uso da informação (CAIRO, 2013, p.18; FRASCARA, 2011, p.49; GIANNELLA, 2014, p.20; HORN, 2000, p.15; JACOBSON, 2000, p.02; PASSINI, 2000, p.85; TUFTE, 2007, p.191; WINKLER, 2011, p.60). 0 propósito final é a revelação do complexo (TUFTE, 2007, p.191, tradução nossa) e o fornecimento

\footnotetext{
${ }^{7}$ Para Raskin (2000, p.342) o termo “design da informação" é equívoco porque não se pode aplicar design diretamente à informação, mas sim ao meio pelo qual ela é transmitida.

${ }^{8}$ Em 2000, Jacobson relatava que o Design da Informação começava a se difundir, e que cinco anos antes, era ainda "pouco conhecido na América do Norte, Ásia e Europa", sendo praticado apenas por "pequenos grupos de crentes concentrados no Reino Unido e na Holanda" (JACOBSON, 2000, p.02, tradução nossa). Já Winkler calculava, em 2011, que "somente nas últimas quatro ou cinco décadas os designers têm descoberto o 'design de informação'" (WINKLER, 2011, p.57, tradução nossa).
} 
dos dados objetivos necessários que possibilitem ao usuário a tomada de uma decisão (WILDBUR; BURKE, 1998, p.6).

As aplicações práticas da disciplina são variadas, abrangendo sistemas de comunicação tanto analógicos quanto digitais (CAIRO, 2013, p.18; SBDI, s.d.). Compreendem desde manuais de instrução até tabelas de horário, de formulários a faturas, de placas de trânsito a sinalização ambiental, de layouts impressos a ambientes virtuais, de mapas de localização à divulgação científica.

0 campo de estudo, inevitavelmente, firma raízes em uma multiplicidade de disciplinas, desde as artes gráficas até a linguística, passando pela lógica, tipografia e ergonomia. Alia a prática à teoria da informação e às ciências cognitivas, estabelecendo a "união do design com a pesquisa" (PASSINI, 2000, p.85, tradução nossa). Sua abordagem científica, fundamentada na percepção, também suscitaria regras de aplicação que "transcendem os caprichosos modismos do design" por serem embasadas na estrutura "relativamente estável do sistema visual humano" (WARE, 2000, p.xviii-xix, tradução nossa).

\subsubsection{ORIGENS DA DISCIPLINA}

Uma hipótese bastante aceita é a de que o Design da Informação moderno surgiu na década de 1970. 0 termo, que era inicialmente utilizado por uma pequena comunidade de designers e pesquisadores - uma "universidade invisível"9 (MAZUR, 2003, p.19; STIFF, 1999, p.xii; WALLER, 2008, p.1) -, foi consolidado durante a Conferência NATO sobre a Apresentação Visual da Informação, realizada na Holanda em $1978^{10}$. Na conferência adotou-se uma abordagem interdisciplinar, envolvendo psicólogos cognitivos, pesquisadores de fatores humanos, engenheiros, tipógrafos e

\footnotetext{
${ }^{9}$ As universidades invisiveis, ou colégios invisíveis constituem canais informais de comunicação científica e tecnológica, empregando diversas formas de interação interpessoal. "Em muitos casos, são os colégios invisíveis mais responsáveis pela geração de novas ideias e pela aceleração do tempo de transferência da informação do que os canais formais de difusão" (ZAMBONI, 2001, p.34). Mais adiante discorreremos sobre o surgimento da primeira universidade invisível, ocorrido no séc. XVII.

10 Mazur (2003, p.18) aponta que oito anos antes, em 1970, Edward A. Hamilton já havia empregado o termo "profeticamente" em Graphic Design for the Computer Age, declarando que: "o designer da informação é na realidade um professor - e não há melhor elogio para um designer profissional que chamá-lo de professor".
} 
designers, na busca por aproximar pesquisa visual e perceptiva aos problemas práticos da exposição de informação.

No ano seguinte foi lançado o Information Design Journal (IDJ), publicação cujo alcance internacional contribuiu para dar visibilidade ao Design da Informação como uma disciplina estabelecida. Fundamental também foram a criação do International Institute for Information Design (IIID), na Áustria em 1986, e da Information Design Association (IDA), na Inglaterra em 1991.

No Brasil, em 2002, foi fundada a SBDI - Sociedade Brasileira de Design da Informação, com a missão de contribuir para o desenvolvimento científico e tecnológico da disciplina no país. Dentre suas atividades destacam-se a organização do CIDI - Congresso Internacional de Design da Informação e a publicação da revista InfoDesign - Revista Brasileira de Design da Informação, pioneira na América Latina nesta temática (SBDI, s.d.).

Mas apesar de representar uma nova disciplina acadêmica, o Design da Informação toma como referência antigas áreas do conhecimento (PETTERSSON, 2013, p.221) e suas atividades podem ser entendidas como resultado de um processo evolutivo de origem muito mais longínqua. $A$ necessidade de registro e armazenamento de informação, inerente à humanidade, fez da apresentação visual de dados uma atividade "tão antiga quanto qualquer cultura ou grupo social" (WINKLER, 2011, p.57, tradução nossa). Na visão de Horn (2000, p.15), o Design da Informação seria a mais recente manifestação da milenar profissão de assistência à comunicação. Hoje simplesmente empregamos as "enormes capacidades das novas tecnologias para fazer aquilo que já fizemos no passado - mesmo que em escalas muito maiores, de forma muito mais rápida, por distâncias maiores, e com muito mais frequência" (DERVIN, 2000, p.36, tradução nossa).

O percurso histórico da representação visual de dados já foi descrito por uma significativa quantidade de autores (dentre os quais CAIRO, 2008; FEW, 2009; FRIENDLY e DENIS, 2001; HORN, 2000; KANNO, 2013; TUFTE, 2007), mas para a construção de nosso raciocínio, julgamos necessário relacionar alguns profissionais e movimentos que, além de serem frequentemente citados na literatura referente ao Design da Informação, tiveram impacto no desenvolvimento da ciência ou na divulgação de seus resultados:

\section{a) René Descartes}

No séc. XVII, Descartes promoveu a fusão da geometria com a álgebra, dando origem à geometria analítica. Dentre outros feitos, o matemático demonstrou que dois números podiam in- 
dicar a posição de um ponto sobre uma superfície usando apenas duas linhas (as coordenadas $x \mathrm{e}$ y), sistema que ainda hoje permanece largamente utilizado (HOLMES, 2012).

\section{b) John Snow}

Data de 1854 um dos exemplos mais antigos de visualização empregada para a investigação de dados. Na ocasião, um médico que pesquisava as causas de uma epidemia de cólera que atacara Londres, sobrepôs visualmente dois grupos de informações: a quantidade de mortes causadas pela doença e o mapeamento de suas respectivas localizações. Observando a região que concentrava a maior quantidade de mortes, foi possível determinar o foco da doença e a posição exata do poço contaminado. “Obviamente a conexão entre o poço e a doença poderia ter sido revelada por cálculo e análise sem o uso de gráficos, com alguma sorte e muito trabalho", mas este é um exemplo no qual "a análise gráfica testifica sobre os dados de forma muito mais eficiente que o cálculo" (TUFTE, 2007, p.24, tradução nossa).

\section{Figura 5. Mapa de John Snow, 1854.}

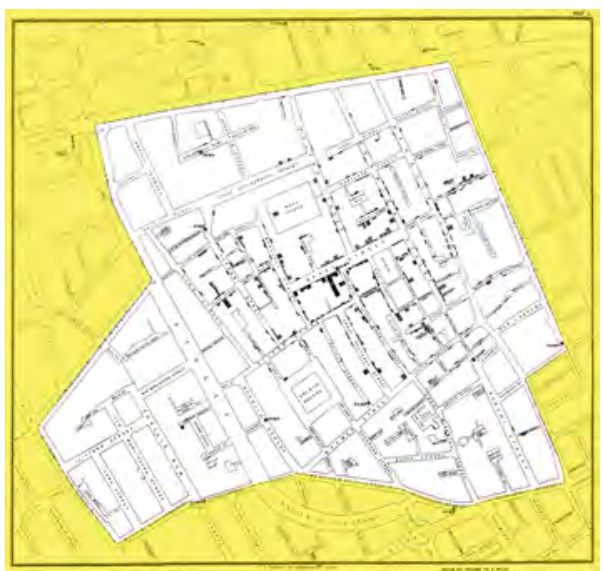

Fonte: UCLA, s.d. ${ }^{11}$.

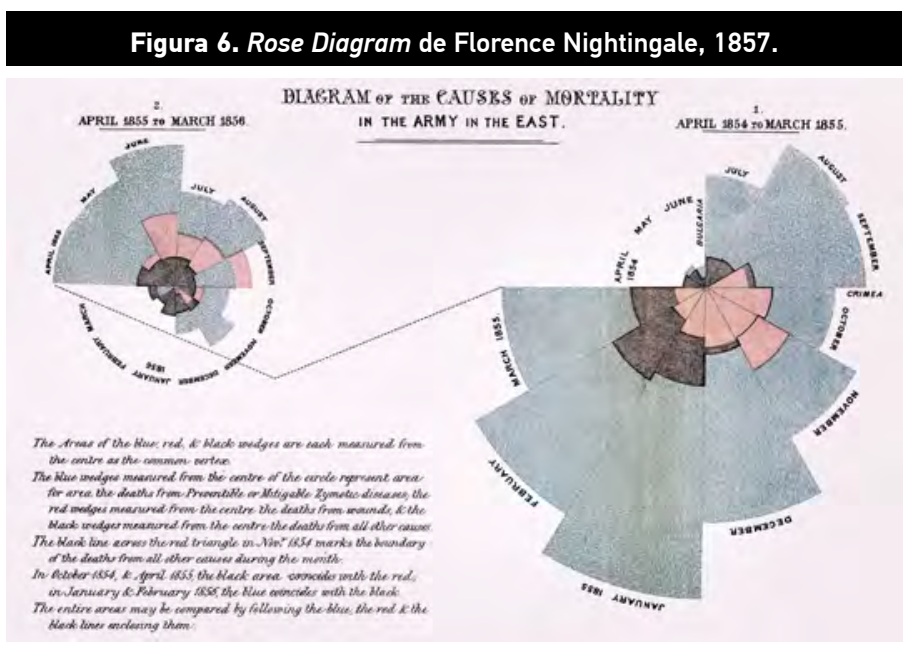

Fonte: NORMAN, s.d. ${ }^{12}$.

\section{c) Florence Nightingale}

Após tratar de milhares de soldados durante a guerra da Crimeia (1853-1856), a enfermeira constatou que a maioria das mortes registradas haviam sido causadas por doenças infecciosas adquiridas no próprio hospital. Para convencer o governo britânico a tomar medidas preventivas, Nightingale criou um gráfico mais visual que numérico, de rápida e fácil compreensão, sustentando que o diagrama deveria "afetar pelos olhos aquilo que falhamos em transmitir ao cérebro do público

\footnotetext{
${ }^{11}$ Disponível em: <http://www.ph.ucla.edu/epi/snow/snowmap1_1854_lge.htm>. Acesso em: 02 mar. 2017.

12 Disponivel em: <http://www.historyofinformation.com/expanded.php?id=3815>. Acesso em: 02 mar. 2017.
} 
através de seus ouvidos à prova de palavras" (NIGHTINGALE apud STONE, 2001, p.172, tradução nossa). 0 diagrama evidenciou a discrepância entre a quantidade de mortes por doenças infecciosas (área em azul) e por ferimentos em batalha (área em vermelho). Como resultado, as práticas médicas do exército britânico passaram por significativas reformas, uma das quais a criação de um novo Departamento de Estatística Médica (SAUTOY, 2010).

\section{d) Charles Minard}

No âmbito das ciências humanas, destaca-se a Carte Figurative de Minard. A Campanha da Rússia, liderada por Napoleão Bonaparte em 1812, foi representada com notável poder de síntese neste diagrama que ilustra, simultaneamente, múltiplas sucessões de eventos: a quantidade decrescente de soldados do exército francês; sua localização geográfica e trajeto percorrido; a movimentação de tropas auxiliares; as temperaturas e datas em alguns momentos-chave.

\section{Figura 7. Carte Figurative de Charles Minard, 1869.}

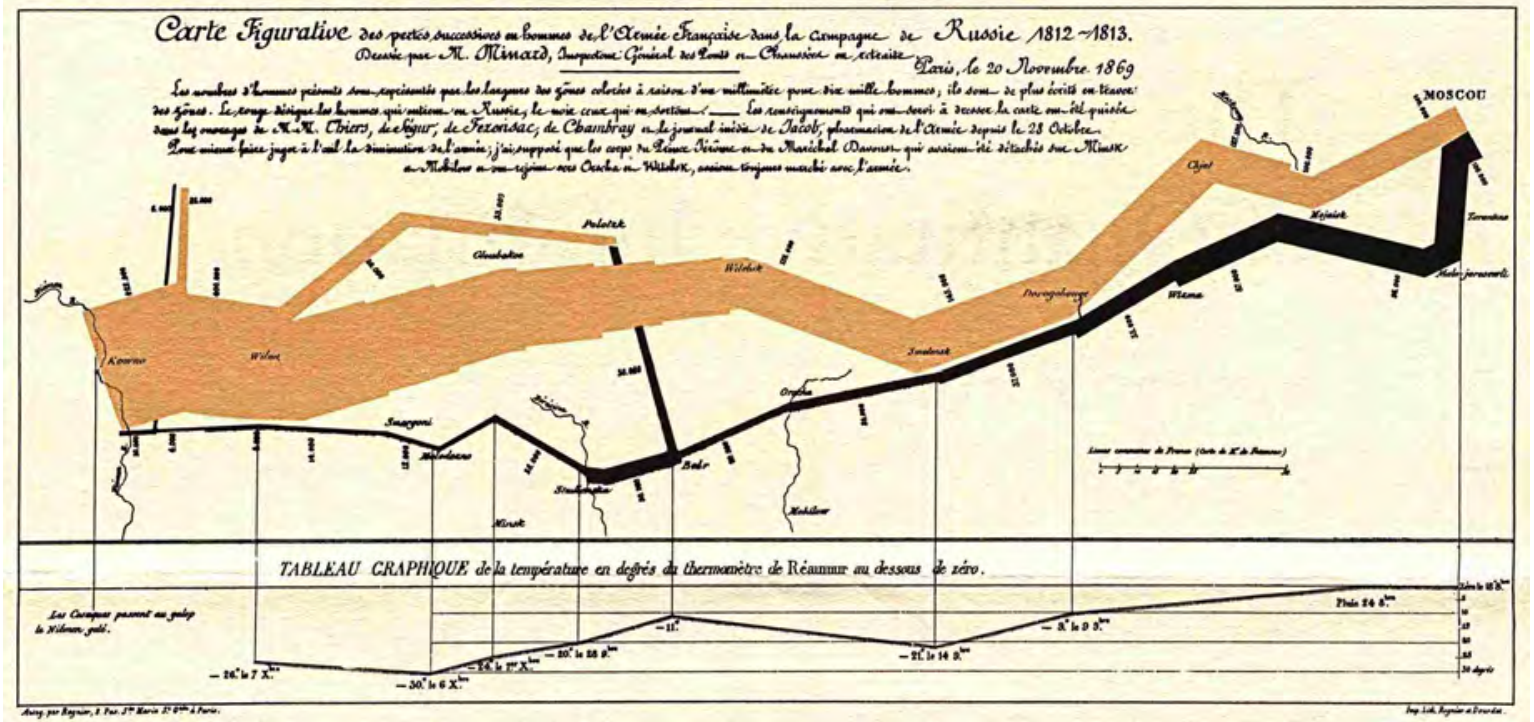

Fonte: ALCHETRON, s.d. ${ }^{13}$

\section{e) Universalistas}

Fundamental para a evolução do Design da Informação foram os movimentos que promoveram a comunicação iconográfica e uma padronização da expressão visual. Na Bauhaus (escola que funcionou na Alemanha de 1919 a 1933 e que pregava a racionalidade e a funcionalidade), foram

$\overline{13}$ Disponível em: <https://alchetron.com/Charles-Joseph-Minard-1110474-W>. Acesso em: 02 mar. 2017. 
criados sistemas de símbolos gráficos que deveriam transmitir conceitos específicos e compor uma gramática essencialmente visual que se comunicaria diretamente com os "olhos e cérebro", independente de língua ou convenções culturais (LUPTON, 1988). Outro esforço por uma linguagem puramente visual foi o Isotype (International System of Typographic Picture Education), sistema visual proposto pelo sociólogo Otto Neurath em 1936, que visava transmitir complexos dados estatísticos de forma didática, utilizando figuras simples e concisas.

No Estilo Tipográfico Internacional, movimento surgido na Suíça e na Alemanha durante a década de 1950, pregava-se uma "abordagem mais universal e científica para a solução de problemas de design" (MEGGS, 2009, p.462-463). Os tipógrafos retiraram as serifas e desenvolveram fontes menos rebuscadas que favoreciam a leitura - como a Helvetica, de Max Miedinger, e a Univers, de Adrian Frutiger. Posteriormente, este último desenvolveu a tipografia Frutiger para a sinalização do Aeroporto Internacional Charles De Gaulle, em Paris. Os caracteres simples e bastante distintos entre si podiam ser lidos com facilidade por transeuntes das mais diversas nacionalidades.

Outro programa que demandava atenção à universalidade da comunicação eram os Jogos Olímpicos, para os quais foram criados símbolos de compreensão intuitiva: os pictogramas. Os primeiros modelos surgiram nos Jogos de Inverno da Alemanha (1936), mas o recurso só passou a ser utilizado com regularidade a partir das Olimpíadas de Tóquio (1964). Atualmente, o emprego de pictogramas difundiu-se por diversas esferas, incluindo a comunicação médica e de instruções farmacêuticas - beneficiando principalmente usuários de "baixo nível de letramento" (MATOS, 2009, p.117) (Figura 8).

Figura 8. Pictogramas de instruções farmacêuticas do RAD-AR Risk-benefit assessment of drugs. Tóquio, 2006.

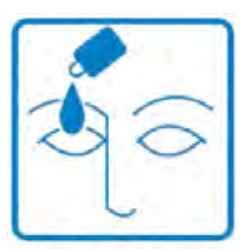

Colírio (Aplicar no olho)

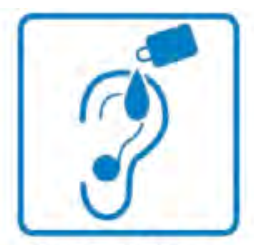

Gotas otológicas (Aplicar no ouvido)

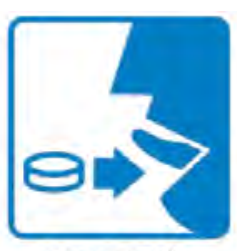

Comprimido sublingual

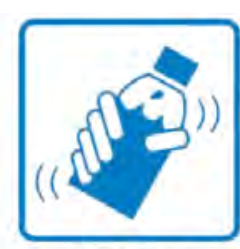

Agitar bem antes de usar

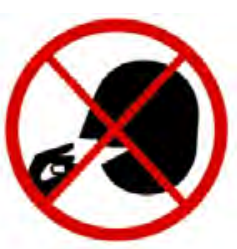

Năo ingerir

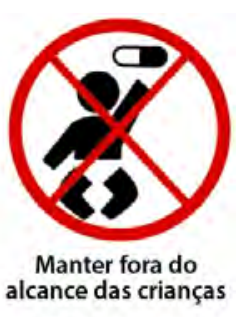

Fonte: EGOTA, 2017.14

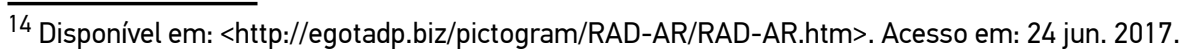




\subsubsection{O DOCUMENTADOR VISUAL DA CIÊNCIA}

A participação do documentador visual na produção científica também foi se modificando ao longo da história. No domínio das ciências médicas, por exemplo, as ilustrações dos atlas anatômicos eram inicialmente bastante esquemáticas, empregando figuras abstratas para mostrar a posição e função dos órgãos (RENDGEN, 2012, p.10). Os estudos da fisiologia humana por Galeno de

\section{Figura 9. Esquema fisiológico por Galeno.}

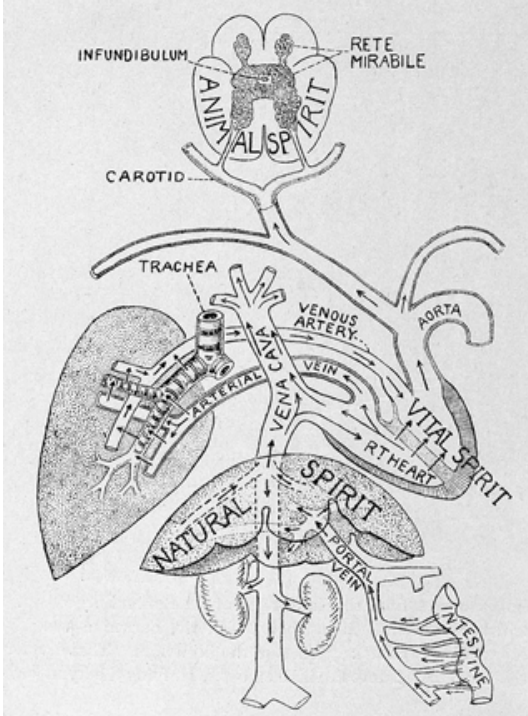

Fro. 21--Diagram illustrating Galen's physiological scheme. Fonte: BECPL, s.d. ${ }^{15}$

\section{Figura 10. llustração por Andreas Vesalius.}

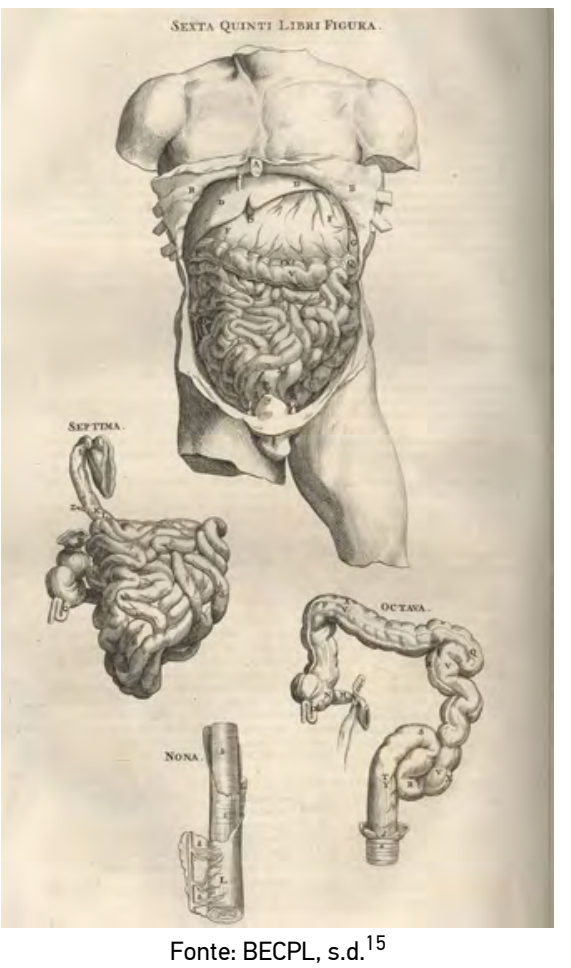

Pérgamo (séc. II) foram dominantes no ocidente por mais de um milênio, apesar de serem frequentemente baseados na observação de macacos e outros animais, apresentando um número de equívocos (WINKLER, 2011, p.62). Foi somente em 1543 que Andreas Vesalius - estudante de arte e medicina - publicou ilustrações anatomicamente corrigidas (Figuras 9 e 10).

Analogamente, Nicolaus Copernicus (1473-1543), Galileu Galilei (1564-1642) e Johannes Kepler (1571-1630) tiveram papel central no desenvolvimento da Revolução Científica que teve início no Iluminismo Europeu, graças não apenas aos seus estudos dos astros, mas também às suas habilidades para documentar e comunicar suas observações de forma visual (WINKLER, 2011, p.62). De fato, ilustrações já estiveram "bem integradas ao texto em manuscritos científicos, como os de Newton e Leonardo da Vinci" (TUFTE, 2007, p.181, tradução nossa), em épocas nas quais "observador científico e documentador visual eram a mesma pessoa" (WINKLER, 2011, p.61, tradução nossa).

No âmbito da divulgação do conhecimento, as imagens foram gradualmente segregadas do texto. Quando livros eram copiados manualmente, as letras eram mais facilmente registradas que as imagens, já que o copista precisava apenas saber identificar e reproduzir o conjunto

\footnotetext{
${ }^{15}$ Disponivel em: $<$ https://goo.gl/5DT5GK>. Acesso em: 24 jun. 2017.

16 Disponível em: <https://goo.gl/YMSFaU>. Acesso em: 24 jun. 2017.
} 


\section{Figura 11. Representação da \\ molécula de benzeno.}

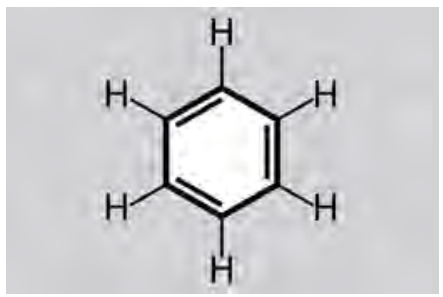

Fonte: ISODA, 2013, p.51.

reduzido de símbolos que compunham o alfabeto. Ainda que as letras não fossem desenhadas de forma idêntica, preservava-se o sentido. Por outro lado, as ilustrações sofreram certa degeneração "porque até mesmo os artistas habilidosos não entendiam a ilustração que estavam copiando" (ONG apud SILVEIRA, 2010, p.29). Mesmo no início da história da imprensa, reproduções imagéticas eram mais raras por falta de "compatibilidade mecânica" para unir no mesmo processo de impressão a matriz tipográfica e a matriz xilográfica - ou, posteriormente, a litográfica (ARBACH, 2007, p.111).

A popularização da fotografia (no final do séc. XIX), devido à sua natureza automática, tem sido associada a um afastamento ainda maior entre as tarefas visuais e científicas. Na visão de Winkler, estabeleceu-se um período em que "nem fotógrafo nem designer gráfico precisam ter interesse, afinidade ou conhecimento do tema que estão apresentando" (WINKLER, 2011, p.61, tradução nossa).

Ainda assim, diversos pesquisadores de áreas que não permitiam observação direta de seus objetos continuaram desenvolvendo representações gráficas para defender suas ideias. Em 1865, por exemplo, o químico August Kekulé, desvendou a fórmula estrutural da molécula de benzeno $\left(\mathrm{C}_{6} \mathrm{H}_{6}\right)$, representando-a por uma forma hexagonal que não é visualmente similar à molécula em questão, mas a exprime conceitualmente (Figura 11). Outros exemplos são a representação do átomo por Niels Bohr (1913) e a grandeza vetorial simbolizada por setas em estudos de Física (ISODA, 2013, p.51).

Com o estabelecimento da disciplina do Design da Informação, a figura do documentador visual aproxima-se novamente da ciência, passando a colaborar com o processo global: desde a investigação científica até a divulgação coerente de seus resultados. De passivo estilizador, o designer torna-se ativo negociador de comunicação (WINKLER, 2011, p.60). Esse profissional, o "transformer" - conceito criado por Otto Neurath -, atua na interface entre os coletores de dados e os artistas gráficos (NEURATH e KINROSS, 2009, p.77-96). Nas palavras de Campos, editora de infografia da Pesquisa FAPESP, a responsabilidade do "transformer" pressupõe uma proximidade com o conhecimento científico: 


\section{2 \\ O QUE É UM INFOGRÁFICO?}

Os infográficos, objeto específico da presente análise, são frequentemente delimitados de forma restritiva, definidos apenas como uma "contribuição informativa, elaborada no jornal impresso", que facilita a compreensão dos "acontecimentos, ações ou coisas da atualidade" (SANCHO apud CAIRO, 2008, p.21, tradução nossa). Preferimos, no entanto, adotar noção mais ampla, na qual infográficos são tidos como recursos que transformam "problemas complexos em imagens fáceis de entender" (RENDGEN, 2012, p.9), independentemente do veículo que os suporta (CAIRO, 2008, p.21).

Para Kanno (2013, p.11), a função da infografia não se restringe a simplificar o difícil; mas é evidenciada naquelas situações em que o texto isolado não configura estrutura ideal para apresentar determinado conteúdo informativo, fazendo da associação "texto + imagem" a forma mais adequada de comunicação.

Mas qual, exatamente, é o formato de um infográfico? Quais estruturas semântico-sintáticas podem ser consideradas como tal? Podemos explorar esta questão a partir da investigação do termo original para infográfico. A expressão é proveniente da palavra em inglês infographics, que por sua vez seria a abreviação de information graphics $^{17}$ (CAIRO, 2008, p.21; KANNO, 2013, p.10; LUCAS, 2010, p.4; SILVEIRA, 2010, p.57). Alguns estudos em língua portuguesa e espanhola, no entanto, apontam que pode haver um equívoco na tradução do termo (GIANNELLA, 2014, p.66; RIBAS, 2005, p.5; SANCHO, 2001, p.19).

Ribas (2005, p.5) explica que, na língua inglesa, a expressão graphics equivale a diagram, mas que diagram não necessariamente equivale a chart ou graph (que seriam as traduções corretas para 'gráfico', em português). Chart e graph podem ser diagram, mas o contrário não ocorre, ou

\footnotetext{
${ }^{17}$ A revista Newspaper Techniques, cujos textos faziam referência a information graphics até 1988, passou a empregar o termo infographics a partir de 1989 (LUCAS, 2010, p.4).
} 
seja, diagram não é o mesmo que chart ou graph (Figura 12). Isto permite sugerir que a tradução mais correta para infographics seja "diagrama informativo", termo que abrangeria uma gama maior de estruturas semântico-sintáticas.

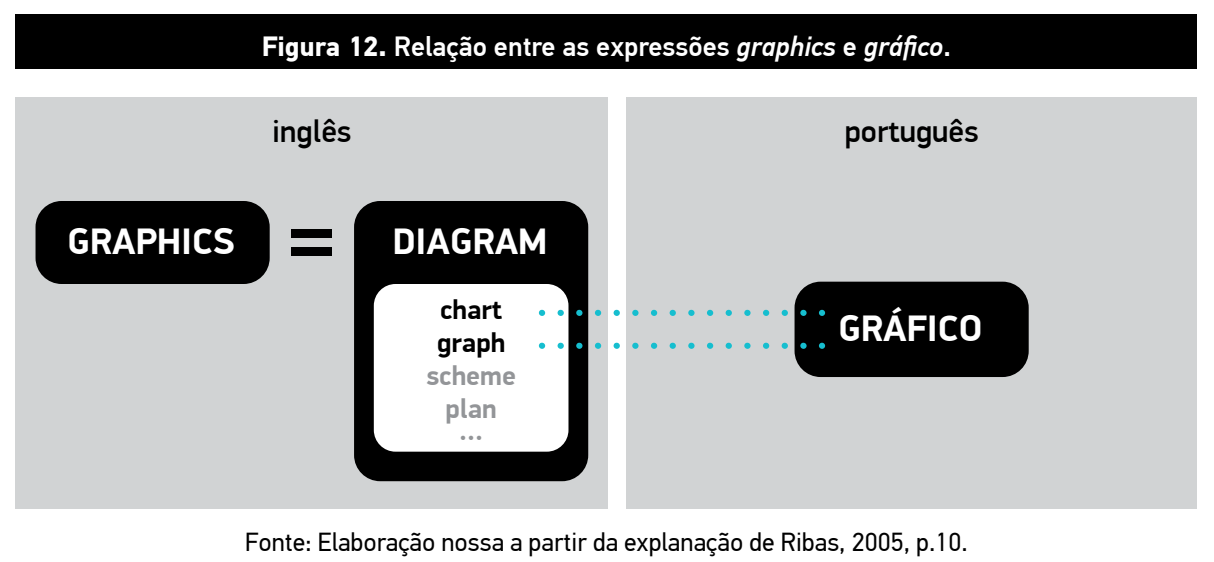

Partindo do suposto de que os infográficos apresentam possibilidades estruturais que vão além dos gráficos e mapas, alguns autores assumem, como consequência inversa, que estas últimas estruturas não podem compor, isoladamente, infográficos (CAMPS e PAZOS apud SOJO, 2002; DE PABLOS, 1999, p.103; RIBAS, 2005; TEIXEIRA, 2010, p.33). Alega-se que, diferentemente de mapas e gráficos, a infografia "pressupõe uma narrativa" (TEIXEIRA, 2010, p.33).

Giannella (2014, p.67) discorda deste posicionamento, salientando que o argumento supracitado "distancia-se do atual cenário produtivo, no qual infográficos que cruzam dados quantitativos e geográficos se tornam cada vez mais evidentes na prática jornalística contemporânea". A autora cita como exemplo dois gráficos de dados (sem direcionamentos narrativos) que foram contemplados na principal premiação de infografia mundial, o Malofiej Awards: Sector Snapshot: Retailing ${ }^{18}$, do The New York Times (vencedor em 2007) e State Gun Laws Enacted in the Year After Newtown ${ }^{19}$, também do The New York Times (vencedor em 2014).

Outros autores (CAIRO, 2008; LETURIA, 1998; SANCHO, 2001) também concordam que o termo infográfico pode englobar as diversas estruturas diagramáticas individualmente: “Qualquer informação apresentada na forma de diagrama - isto é, 'desenho no qual se mostram as relações entre as diferentes partes de um conjunto ou sistema' - é uma infografia" (CAIRO, 2008, p.21, tradução nossa).

\footnotetext{
18 Versão atualizada disponível em: <http://www.nytimes.com/packages/khtml/2006/04/02/business/20060402_SECTOR_GRAPHIC.html>. Acesso em: 17 jul. 2017.

${ }_{19}$ Disponível em: <http://www.nytimes.com/interactive/2013/12/10/us/state-gun-laws-enacted-in-the-year-since-newtown. html>. Acesso em: 17 jul. 2017.
} 
Por fim, entendemos que a definição da infografia deve abranger tanto sua forma estrutural diagramática quanto sua característica funcional: a de permitir a compreensão de fatos ou dados complexos. É justamente por sua função explanatória que o formato faz-se tão presente em publicações de Divulgação Científica. Holmes (apud LIMA, 2009, p.23), inclusive, prefere empregar o termo explanation graphics (gráficos de explanação), por tratar-se menos de uma representação genérica de informação e mais de uma forma sofisticada de explicação visual. Na presente pesquisa, portanto, consideraremos que:

Os infográficos são recursos gráficos que conjugam imagens, palavras e símbolos de forma integrada, visando facilitar a assimilação de determinada carga informativa e enriquecer a experiência do receptor com tal conteúdo, numa relação em que tanto elementos visuais quanto verbais possuem valor de informação, atuando em sincretismo.

\subsubsection{TEXTO E IMAGEM}

0 ser humano é uma espécie simbólica (DEACON, 1998, p.22), que transforma em representações tudo o que está ao alcance dos sentidos (CAIRO, 2013, p.xv). Os símbolos e códigos que constituem nossa comunicação, como o alfabeto e mesmo a linguagem verbal, são instrumentos criados, não naturais. Mas de tão habituados aos sistemas comunicacionais, tendemos a nos esquecer dessa artificialidade e os códigos tornam-se uma espécie de segunda natureza (FLUSSER, 2007, p.90).

Conforme a edição de 2017 do Ethnologue, catálogo que reúne, desde 1951, informações coletadas por linguistas e pesquisadores de todo o mundo, existem atualmente 7.099 línguas vivas (SIMONS e FENNIG, 2017). Tais idiomas, assim como os inúmeros outros que já deixaram de ser utilizados, integram a enorme totalidade de códigos criados pelo homem com a intenção de não 
apenas trocar mensagens, mas também armazenar dados e descobertas, e passá-los às gerações seguintes. Esse desejo por conservar o conhecimento consiste em mais um aspecto não natural da comunicação humana (ela é negativamente entrópica ${ }^{20}$ ) e é uma característica exclusiva da espécie: o homem "é um animal que encontrou truques para acumular informações adquiridas" (FLUSSER, 2007, p.93).

Desses "truques", o mais evidente seria a escrita, que se aprimorou na medida em que as simbologias em uso foram sendo sistematizadas. Segundo Higounet (2003, p.12-15), o desenvolvimento da escrita percorreu três estágios principais, correspondendo à evolução das relações entre os símbolos e as mensagens representadas. A primeira fase (cerca de 10 mil a.C.) seria a das escritas sintéticas, nas quais um sinal ou um grupo de sinais representava uma frase inteira, ou as ideias nela contidas. Essa "escrita das ideias" seria a evolução natural das pinturas rupestres e suas mensagens seriam limitadas. Já na etapa das escritas analíticas, as frases passaram a ser decompostas, originando uma "escrita de palavras". São dessa categoria os hieróglifos egípcios (cerca de 3300 a.C.) e a escrita cuneiforme suméria (cerca de 3000 a.C.), que influenciaram nosso alfabeto. Outro exemplo é a escrita ideográfica chinesa, que ainda permanece em uso e que tem influência sobre outras escritas do leste asiático como a japonesa e a coreana. No terceiro estágio, das escritas fonéticas (silábicas e alfabéticas), os símbolos deixaram de denotar palavras para denotar sons, o que viabilizou significativa redução na quantidade de sinais gráficos. Pertencem a essa fase os alfabetos fenício, aramaico, grego e latino (empregado na língua portuguesa). 0 êxito dessas escritas fonéticas se deveria ao fato de que seus signos gráficos são representações do "mais extremo e mais universal exemplo de seleção cultural - o sistema fonêmico básico" (GOODY e WATT, 1963, p.316, tradução nossa).

0 segundo formato comunicacional que investigamos aqui é o da linguagem imagética. Mesmo com o estabelecimento da escrita, as pinturas e ilustrações conservaram relevância ao longo da história. Na Idade Média, por exemplo, desenhos serviam como instrumento didático nos vitrais das catedrais ou nas Bibliae pauperum, que ilustravam passagens bíblicas para transmitir ensinamentos religiosos a populações analfabetas (SILVEIRA, 2010, p.28).

Flusser (2007, p.102) divide sintaticamente os registros de comunicação humana em dois grupos principais: formas em regime de linha ou em regime de superfície. A linha pressupõe uma

\footnotetext{
200 termo entropia (que originalmente refere-se à quantidade termodinâmica que mede o nível de degradação da energia de um sistema) passou a designar a medida de desordem de um sistema. Seria a "extinção e a 'morte', por perda de energia, do universo" (JAPIASSÚ, 2006, p.81). A comunicação humana, portanto, ao procurar ordenar o conhecimento, seria negativamente entrópica.
} 
leitura sequencial, como no caso da escrita alfabética, que se organiza linearmente e condiciona o raciocínio a uma estrutura predeterminada. A linguagem oral e escrita "tornou-se o paradigma do pensamento" (FRASCARA, 2011, p.42-43, tradução nossa), ao ordenar o conhecimento e conferir-lhe propriedade temporal.

Enquanto alguns linguistas concordam que a língua influencia o pensamento, outros acreditam que é a forma de pensar que determina a estrutura da linguagem. Wurman (1991, p.112), no entanto, defende que a relação entre o raciocínio e a expressão verbal seja uma "combinação dessas duas ideias opostas": a linguagem seria tanto um reflexo do pensamento quanto uma influência (ou até uma limitação) sobre o modo como pensamos.

A estrutura da linguagem influiria, inclusive, na organização interna das ideias em culturas específicas. A gramática japonesa, por exemplo, é modular, ao acoplar algumas palavras a outras (chamadas relacionais) de forma a permitir que a ordem das palavras numa frase seja alterada sem afetar o significado. Por conseguinte, a língua torna-se "intrinsecamente mais fácil e menos limitadora para o processo de combinação de palavras" (WURMAN, 1991, p.112-114), fazendo com que um raciocínio modular seja mais natural para os japoneses. A gramática alemã tem estrutura semelhante, possibilitando a combinação de cadeias de ideias em uma única palavra: adjetivos e modificadores podem ser incorporados aos substantivos para formar uma palavra, constituindo um novo conceito. Para Wurman (1991, p.112-114), línguas como a japonesa e a alemã, cujas capacidades e flexibilidade modulares permitem encadear diferentes conceitos em um completamente novo de forma tão "fácil" e "eficaz", incutem às suas culturas correspondentes um raciocínio matemático, que favorece a excelência em ciências exatas, como a engenharia.

Por outro lado, o autor também aponta que existem línguas, como a portuguesa ou a francesa, nas quais objetos inanimados possuem gênero (são ou masculinos ou femininos), o que propiciaria um "ambiente fantástico" que incentiva uma utilização criativa da linguagem, suscitando a formação de ideias novas e diferentes, até estapafúrdias: “Pois, afinal, o que pode ser tão estapafúrdio se você já aceitou que sua caneta é [feminina]?" (WURMAN, 1991, p.114).

Mas a estrutura linear da linguagem verbal dispõe de uma capacidade limitada para a transmissão de ideias em sua totalidade, com todas as complexidades, simultaneidades e multiplicidades. Consequentemente, a "forma típica de pensar de nossa cultura carece de habilidade para conceber ecologias de informação, que são centrais para compreender os problemas habituais de design" (FRASCARA, 2011, p.43, tradução nossa). 
Mensagens bidimensionais também permitem uma estrutura de raciocínio menos programada e menos linear. A leitura de uma pintura, por exemplo, é bastante distinta da de um texto escrito, cuja ordem sequencial deve ser respeitada. Já no caso da pintura, é possível primeiro abarcar a imagem toda, para então esmiuçar suas partes. Essa síntese e posterior exploração consistem num processo autônomo, sem um programa predeterminado e que pode ser repetido livremente durante uma única leitura.

Por sua objetividade, alguns autores defendem que os códigos alfabéticos possibilitam leituras mais claras e nítidas, tornando possível escrever e ler "facilmente e sem qualquer ambiguidade todas as coisas sobre as quais a sociedade possa falar" (GOODY; WATT, 1963, p.316, tradução nossa). Por outro lado, representações em superfície permitem mensagens mais ricas e completas. Apesar de a linguagem verbal apresentar maior poder descritivo e de diferenciação, as imagens têm alta densidade informativa (GIANNELLA, 2014, p.28; SILVEIRA, 2010, p.21) e costumam ser mais eficientes quando o conteúdo é "emocional, holístico, imediato, espacial e visual" (PETTERSSON, 2015, p.208, tradução nossa).

Os produtos do Design da Informação parecem indicar um sincretismo de ambas as linguagens. Ao combinarem elementos imagéticos à linguagem alfabética, contribuem para elevar os níveis de clareza e nitidez de mensagens complexas, ao passo que permitem a transmissão de um conteúdo mais rico e abrangente.

Nos infográficos, por exemplo, elementos unidimensionais e bidimensionais "estão inseparavelmente entrelaçados para produzir entidades únicas" (RENDGEN, 2012, p.9, tradução nossa), estruturadas de forma a permitir que o leitor navegue entre os elementos disponíveis conforme seu interesse específico e na ordem de sua preferência. A leitura, portanto, é tanto em linha quanto em superfície. A eficácia de comunicação de uma figura retórica visual-verbal decorre da "tensão entre as suas características semânticas. Os sinais não se somam mais, mas operam em relações recíprocas cumulativas" (BONSIEPE apud KONG, 2006, p.209, tradução nossa).

Plaza (2003, p.206) enxergava a fusão das estruturas de comunicação como um sintoma da pós-modernidade, que estaria sendo tomada "por uma imensa inflação babélica de linguagens, códigos e hibridização dos meios tecnológicos que terminam por homogeneizar, pasteurizar e rasurar as diferenças: tempo de mistura". 
Além do potencial sincrético das linguagens unidimensionais e bidimensionais, a disseminação de ferramentas gráficas e o acesso imediato a dados estatísticos têm contribuído para uma profusão da infografia e para um interesse generalizado por esta forma de representação visual (CAIRO, 2013, p.14; RENDGEN, 2012, p.9). No entanto, a inconveniência desta popularização tem sido um certo "nível de degeneração" (RENDGEN, 2012, p.12. tradução nossa), comprometendo a qualidade na produção dos infográficos - seja no caráter estético; seja na clareza e efeitos cognitivos; seja na correta interpretação dos dados por parte do designer -, o que justifica a necessidade de estudos críticos abordando o tema. No capítulo a seguir, investigamos alguns aspectos implicados na infografia eficiente, visando àquilo que Tufte (2007, p.51) denominou “excelência gráfica". 
Capítulo 3

DESIGNHAR A INFORMAÇÃOO 


\section{Capítulo 3 DESIGNHAR A INFORMAÇÃ̃o}

Souza (2010, p.8) adota um neologismo para se referir ao ato de fazer design: designhar é unir desenho (traço) com desígnio (intenção). Significa "desenhar uma ideia no pensamento" e co-municá-la aos outros por meio de um desenho que irá afetá-los na mente, no coração, na intenção e na ação. Investigamos aqui o modo prático como se dá a comunicação promovida pelo design, ana-lisando o processo segundo o qual um desenho cumpre seu desígnio inicial.

Há modos de apresentação visual que conduzem a uma decodificação gráfica eficiente e precisa, e é "somente através do estudo científico da percepção visual" que podem ser feitos julgamentos fundamentados sobre esses métodos de exibição (CLEVELAND, 1994, p.1, tradução nos-sa). Por conseguinte, iniciamos este capítulo com uma investigação da visão, atividade complexa que envolve um "amplo espectro de processos, atividades, funções, atitudes" (DONDIS, 2007, p.5).

Já na segunda parte do capítulo, delineamos alguns princípios diagramáticos e identifica-mos estratégias visuais empregadas por designers para uma eficiente comunicação e produção de conhecimento. 


\section{1}

\section{O PROCESSO COGNITIVO}

Dentro de nossas mentes, ver e compreender são processos entrelaçados (CAIRO, 2013, p.XV), o que indica a complexidade do caráter e do conteúdo da inteligência visual (DONDIS, 2007, p.5). Dizemos que uma mente entende quando ela gera ordem, estruturando os bits de informação que formam a realidade (KELLY, 2010, p.333). Para analisarmos o processo de cognição visual, portanto, devemos estudar aspectos que transcendem o funcionamento do olho, entendendo que a percepção envolve muito mais do que a mera reprodução de imagens no cérebro.

Ao usarmos nossa visão, não estamos apenas

Figura 13. Cubo de Necker.

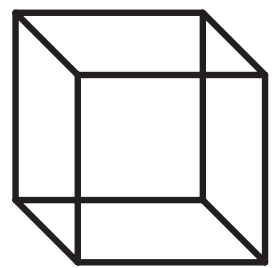

Fonte: Explore Psychology, s.d.

\section{Figura 14. Triângulo de Kanizsa.}

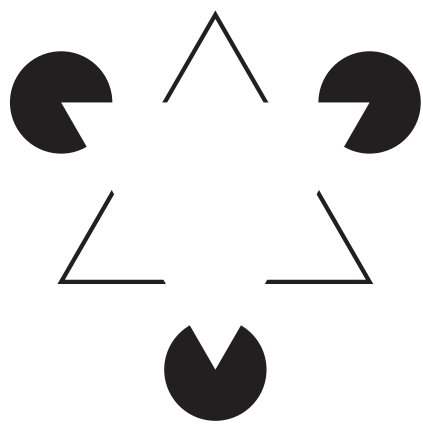

Fonte: Explore Psychology, s.d. captando as cenas, mas analisando e julgando-as. Nossa percepção de algo pode variar significativamente, mesmo que a imagem em nossa retina seja constante. Observando a Figura 13, por exemplo, podemos perceber o cubo tanto apontando para cima e para a esquerda, quanto para baixo e para a direita, dependendo de como nosso cérebro interpreta a imagem. Este experimento simples indica que todo ato de percepção, mesmo de algo trivial como o desenho de um cubo, envolve também um "ato de julgamento pelo cérebro" (RAMACHANDRAN, 2004, p.102).

Em outro modelo, o triângulo de Kanizsa (Figura 14), observadores enxergam um triângulo onde de fato não há, evidenciando a diferença entre "o resultado perceptivo e os dados sensoriais não-elaborados" (MASSIRONI, 2002, p.244, tradução nossa).

\footnotetext{
21 Disponível em: <https://goo.gl/q59M5N>. Acesso em: 14 mar. 2017.

22 Disponível em: <https://goo.gl/d83nG8>. Acesso em: 14 mar. 2017.
} 


\section{Figura 15. Mistura de ovos e cavidades.}

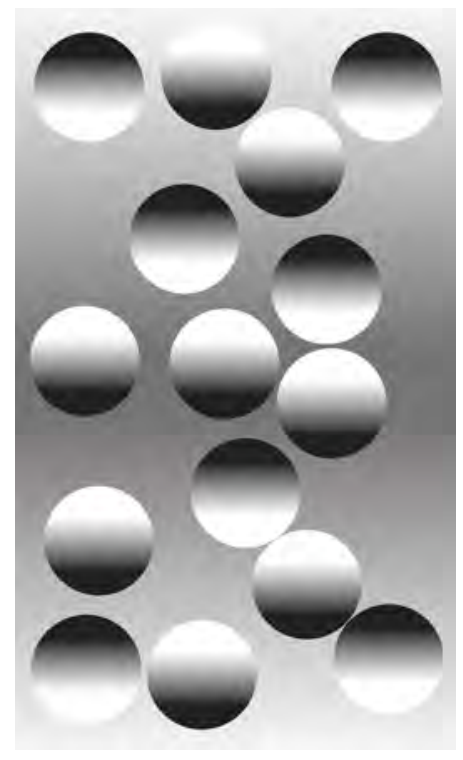

Fonte: Ramachandran, 2004, p.104
Arnheim (1969, p.15) também aponta que a percepção sobre o tamanho dos objetos não necessariamente corresponde ao tamanho relativo de suas projeções na retina. Desta forma, um carro que esteja distante e cuja projeção ótica na retina é menor que a projeção de uma caixa de correio próxima ao observador, parece ter as dimensões normais para um carro. A distorção é corrigida por um “julgamento inconsciente" do cérebro.

Para fazer tais julgamentos, baseamo-nos nas propriedades físicas estáveis que regem o mundo. Durante "a evolução" (e em parte durante a infância), essas propriedades foram incorporadas às áreas visuais do cérebro como "suposições certas" ou "conhecimento oculto" sobre

o mundo, ao qual recorremos para "eliminar ambiguidade na percepção" (RAMACHANDRAN, 2004, p.102). E esse repertório é ampliado ao longo da vida, tornando o aprendizado contínuo (COSTA, 1998, p.89).

Tal "conhecimento oculto" pode ser notado ao observarmos a Figura 15. Os elementos que a compõem são discos planos sombreados, diferenciando-se apenas pelo fato de alguns serem claros na parte superior e outros serem claros na parte inferior. Mas ao olharmos para a imagem, percebemos metade dos discos como se fossem ovos (cujos bojos projetam-se em nossa direção) e a outra metade como cavidades ocas. Prosseguindo na análise, notamos que os discos que são brancos em cima são os que parecem destacar-se para fora do papel, enquanto os que são pretos em cima são os que parecem depressões. Ao virarmos a página de cabeça para baixo, as saliências tornam-se cavidades e vice-versa. Nossa percepção segue esse padrão porque as áreas visuais do cérebro têm uma "suposição embutida" de que o sol sempre brilha a partir de cima, e de que, portanto, um objeto convexo seria iluminado no topo. Uma cavidade, por outro lado, receberia luz embaixo (RAMACHANDRAN, 2004, p.103).

Mas o processo de percepção visual envolve ainda muitos outros aspectos. Entre o momento em que o raio luminoso incide na retina e o momento em que a imagem é percebida pelo cérebro, transcorrem vários milissegundos e diversos processamentos sucessivos. Inicialmente, a imagem que se forma no fundo de cada olho é codificado na forma de impulsos elétricos, que então seguem pelos nervos óticos até o cérebro (COSTA, 1998, p.53). Estudos em neurociência indicam que, no cé- 
rebro, as informações captadas se dividem por duas vias bastante distintas: uma filogeneticamente mais antiga e outra mais nova (mais desenvolvida em primatas).

A primeira via é relacionada às partes do cérebro que nos ajudam a determinar visualmente nossa própria orientação espacial e a posição de objetos ao nosso redor. São informações ligadas à sobrevivência, e boa parte desse processamento visual ocorre muito antes de tomarmos qualquer consciência daquilo que estamos vendo. Essa via antiga não fornece informações sobre o que estamos vendo, nem mesmo identifica qualquer coisa pelo nome. 0 que se identifica por essa via é se estamos de pé ou não e se alguma coisa está se aproximando de nós - nem importa o que essa coisa seja. Esse processamento sucede em uma parte evolutivamente antiga do cérebro conhecida como tronco cerebral, ou cérebro reptiliano, assim chamado porque é o antigo núcleo do nosso cérebro, que temos em comum com os répteis, e responsável por nossas "habilidades básicas de sobrevivência de 'lutar ou correr'" (ROAM, 2008, p.81;264, tradução nossa).

Já na segunda via, ocorrem os processos da "percepção consciente" (RAMACHANDRAN, 2004, p.112). Seus centros de processamento visual estão localizados no neocórtex, que é a parte mais nova do cérebro humano, responsável pela tomada de decisões analíticas, pela nomeação e pelo processamento de alto nível - "praticamente tudo exceto a sobrevivência básica (controlada pelo tronco cerebral) e as emoções (controladas pelo cérebro límbico [...])" (ROAM, 2008, p.265, tradução nossa).

Essa segunda via avança para o núcleo geniculado lateral, que seria uma estação de retransmissão para o córtex visual primário. A informação visual divide-se, então, em duas direções: a) a via do como (nos lobos parietais, região do cérebro que fica acima das orelhas), envolvida com funções espaciais como andar, alcançar objetos, avaliar a distância e direção de um alvo móvel e (no caso dos primatas) pegar um objeto com os dedos e o polegar; e b) a via do o quê (nos lobos temporais, abaixo das têmporas), onde os objetos são reconhecidos e identificados.

Pelas vias do o quê e do como, os sinais visuais são transmitidos para cerca de trinta regiões no córtex visual em que o processamento realmente detalhado ocorre. Cada uma dessas áreas parecem altamente especializadas em extrair diferentes características da cena visual: cor, profundidade, movimento, etc. (RAMACHANDRAN, 2004, p.107-112).

Nossa capacidade de ler, por exemplo, se desenvolve a partir de nossa aptidão para reconhecer objetos (letras e palavras), habilidade relacionada à via do o quê. Se retomarmos os diferentes tipos de escrita elencados no capítulo anterior (sintéticas, analíticas e fonéticas), compreenderemos como o sistema de transcrição determina a forma de leitura. No caso de uma escrita fonética, 
como a nossa, há uma articulação fonética envolvida no processo de leitura. Já no caso de uma escrita ideográfica, como a japonesa, há acesso mais direto à ideia. Como consequência, estudos neurológicos feitos com leitores japoneses indicaram que "os processo cerebrais para decodificarem os ideogramas, em oposição aos que decodificam transcrições fonéticas, ocorrem em pontos distintos do cérebro" (SAENGER, 1995, p.213).

Na eventual lesão de uma ou mais das trinta áreas visuais do cérebro, podemos ser confrontados com estados mentais paradoxais do tipo vistos em alguns pacientes neurológicos. Um exemplo é a "cegueira para movimento" (ocasionada por lesão bilateral na área temporal média), na qual o sujeito mantém uma visão que, na maioria dos aspectos, é normal. Ele consegue identificar as formas dos objetos, reconhecer pessoas e ler livros sem dificuldades, mas ao olhar para algo em movimento, vê uma sucessão de instantâneos estáticos, ao invés da impressão regular de movimento contínuo (RAMACHANDRAN, 2004, p.107).

Todas essas habilidades da visão nos parecem tão naturais que nem nos damos conta do quanto o processo é realmente sofisticado. Normalmente, aceitamos nossa visão "da mesma maneira como a vivenciamos - sem esforço" (DONDIS, 2007, p.6).

Aglioti (et al, 1995), utilizaram uma ilusão visual bastante conhecida para evidenciar a divisão de tarefas entre diferentes áreas visuais do cérebro. Na Figura 16 há dois círculos de mesmo tamanho. 0 primeiro é circundado por onze círculos pequenos, ao passo que o segundo é circundado por cinco círculos grandes. Apesar de serem idênticos, os dois círculos centrais parecem ter tamanhos distintos: o de baixo é percebido pela maioria das pessoas como sendo $30 \%$ menor que

\section{Figura 16. Titchener circles.}
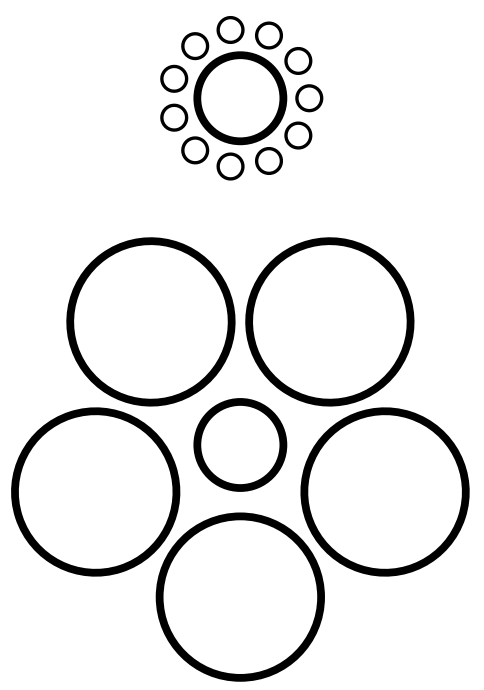

Fonte: Explore Psychology, s.d. ${ }^{23}$ o de cima. A experiência de Aglioti consistiu em arranjar objetos tridimensionais nesta mesma composição. Ao solicitar que um estudante estendesse a mão para pegar os objetos centrais, observou que o participante abria os dedos na distância correta para pegar qualquer um dos dois objetos. Uma análise quadro a quadro revelou que a mão se abria exatamente no mesmo ângulo para pegar ambas as pedras, mesmo que para os olhos uma parecesse $30 \%$ maior. Uma área do cérebro ligada à via do como, responsável pela ação de abrir os dedos para pegar objetos, não era influenciada pela ilusão.

23 Disponível em: <https://goo.gl/PN5kkx>. Acesso em: 14 mar. 2017. 
Ramachandran (2004, p.119) entende que bons atiradores, ou atletas de beisebol e basquete, utilizam informações recebidas por esta via do como em jogadas que dependem significativamente de orientação espacial.

De forma similar, Roam (2008, p.70-71) associa algumas ações "intuitivas" a processos cognitivos que ocorrem em outra região cerebral: o cérebro reptiliano. São atividades que sucedem enquanto reagimos a estímulos sensoriais que não exigem das capacidades mais complexas do cérebro. Quando, por exemplo, olhamos para um avião voando no céu e apertamos os olhos para evitar o sol, estamos experimentando um processo mental de "baixo nível", uma simples reação instintiva. Tais ações podem ser chamadas de "respostas precognitivas" e os inputs sensoriais que as causam seriam os "atributos precognitivos". Segundo o autor, é importante estudarmos como são reconhecidos e processados esses atributos precognitivos, porque isto nos permite identificar quais tipos de imagens (ou partes de imagens) são assimiladas sem nenhum esforço mental consciente. Na tabela do Quadro 1, Roam (2008, p.72) sugere alguns atributos visuais precognitivos "mais comuns", que funcionariam como sinais visuais que nos ajudam a "determinar rapidamente 0 que vale a pena olhar e o que não vale".

\section{Quadro 1. Atributos visuais precognitivos.}

\begin{tabular}{|c|c|}
\hline $\begin{array}{r}\text { Proximidade: nossos olhos presumem que c } \\
\text { Proximidade }\end{array}$ & sas mais próximas umas das outras são relacionadas. \\
\hline \multicolumn{2}{|c|}{$\begin{array}{l}\text { Cor: nossos olhos imediatamente notam diferenças de cor e presumem agrupamentos } \\
\text { com base na cor. }\end{array}$} \\
\hline Cor & $\bullet \bullet \bullet \bullet \bullet \bullet \bullet$ \\
\hline \multicolumn{2}{|c|}{$\begin{array}{l}\text { Tamanho: nossos olhos percebem diferenças de tamanho praticamente sem esforço, } \\
\text { levando à suposiçăo de que o diferente é o que vale a pena ser notado. }\end{array}$} \\
\hline Tamanhe & $\bullet \bullet \bullet \bullet \bullet \bullet \bullet$ \\
\hline \multicolumn{2}{|c|}{$\begin{array}{l}\text { Orientação: nossos olhos instantaneamente distinguem entre orientação vertical e horizontal } \\
\left.\text { (mas têm muito mais dificuldade com ângulos que não sejam } 90^{\circ}\right) \text {. }\end{array}$} \\
\hline Orientaçāe & $----1--$ \\
\hline \multicolumn{2}{|c|}{$\begin{array}{l}\text { Direção: “Destino" é outra palavra para o movimento percebido, algo que também captamos } \\
\text { sem qualquer pensamento consciente [...]. }\end{array}$} \\
\hline $\begin{array}{l}\text { "Destino" } \\
\text { ( Direçāo) }\end{array}$ & t \\
\hline \multicolumn{2}{|c|}{ Forma: Nossos olhos não observam diferenças entre formas tão bem. } \\
\hline Forma & $\bullet\|\Delta \nabla\| \bullet \Delta \nabla$ \\
\hline \multicolumn{2}{|c|}{$\begin{array}{l}\text { Sombreamento: Mas nossos olhos detectam imediatamente diferenças no sombreamento } \\
\text { como uma maneira de distinguir entre para cima e para baixo ou dentro e fora. }\end{array}$} \\
\hline Sombreamente & 000000 \\
\hline
\end{tabular}

Fonte: Tradução e adaptação nossa de Roam, 2008, p.72. 
Tais atributos encontram correspondência no âmbito da Gestalt, escola psicológica que influenciou de forma significativa o design gráfico. Dentre as leis gestálticas que impõem uma estrutura perceptiva na decodificação da informação visual, citamos algumas:

a) Lei do contraste - uma forma é melhor percebida na medida em que se estabelece um maior contraste entre ela e o fundo;

b) Lei da conclusão - a mente tende a completar contornos que não estejam completamente fechados;

c) Lei da continuidade - os elementos que seguem um eixo contínuo constituem uma forma pregnante;

d) Lei do movimento coordenado - os diferentes elementos que participam de um mesmo movimento constituem uma forma pregnante;

e) Lei da continuidade da direção - uma linha curva é percebida como um fragmento de circunferência;

f) Princípio da proximidade - elementos isolados, porém próximos, tendem a ser considerados como grupos ou formas globais;

g) Princípio da similaridade - num campo de elementos espaçados igualmente, aqueles com maior semelhança de forma, tamanho, cor e direção são percebidos como uma cadeia ou grupo homogêneos (COSTA, 1998, p.92-97).

Arnheim (1969, p.69-70) descreve experimentos demonstrando que algumas dessas leis são percebidas por chimpanzés e até mesmo ratos, mas aponta que a extensão de abstração é limitada em cérebros não humanos. Em determinado expe-

Figura 17. Composição triangular.

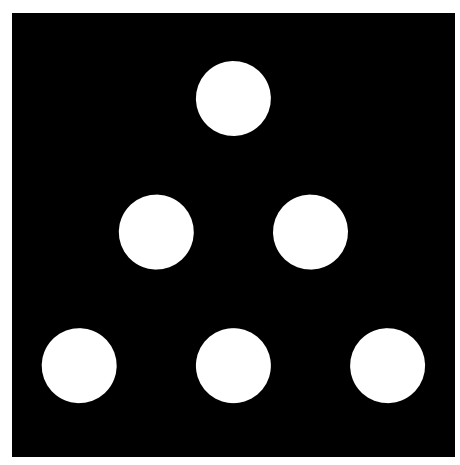

Fonte: Arnheim, 1969, p.70. rimento, um chimpanzé havia sido treinado para identificar um triângulo branco sobre um fundo preto, mas o animal não reagia positivamente a uma composição triangular de seis pontos brancos sobre um fundo preto (Figura 17), mesmo que as dimensões das duas figuras fossem mantidas. A dificuldade residia em conectar os pontos periféricos e internos, completando a figura do triângulo. Por outro lado, uma criança de dois anos era capaz de identificar o triângulo em ambas as figuras. 
A partir dos processos envolvidos na percepção, Roam (2008, p.129-144) propõe um método para a elaboração de representações visuais de ideias ou processos. Seu método inicia com a separação do problema em componentes semelhantes aos caminhos percorridos pelas informações no cérebro: quem/o quê, quanto, onde e quando; que então conduzem aos comos e aos porquês. Segundo o autor, para cada uma dessas seis maneiras de se ver, há uma estrutura visual correspondente (Quadro 2).

\section{Quadro 2. As seis maneiras como vemos e as seis maneiras como mostramos.}

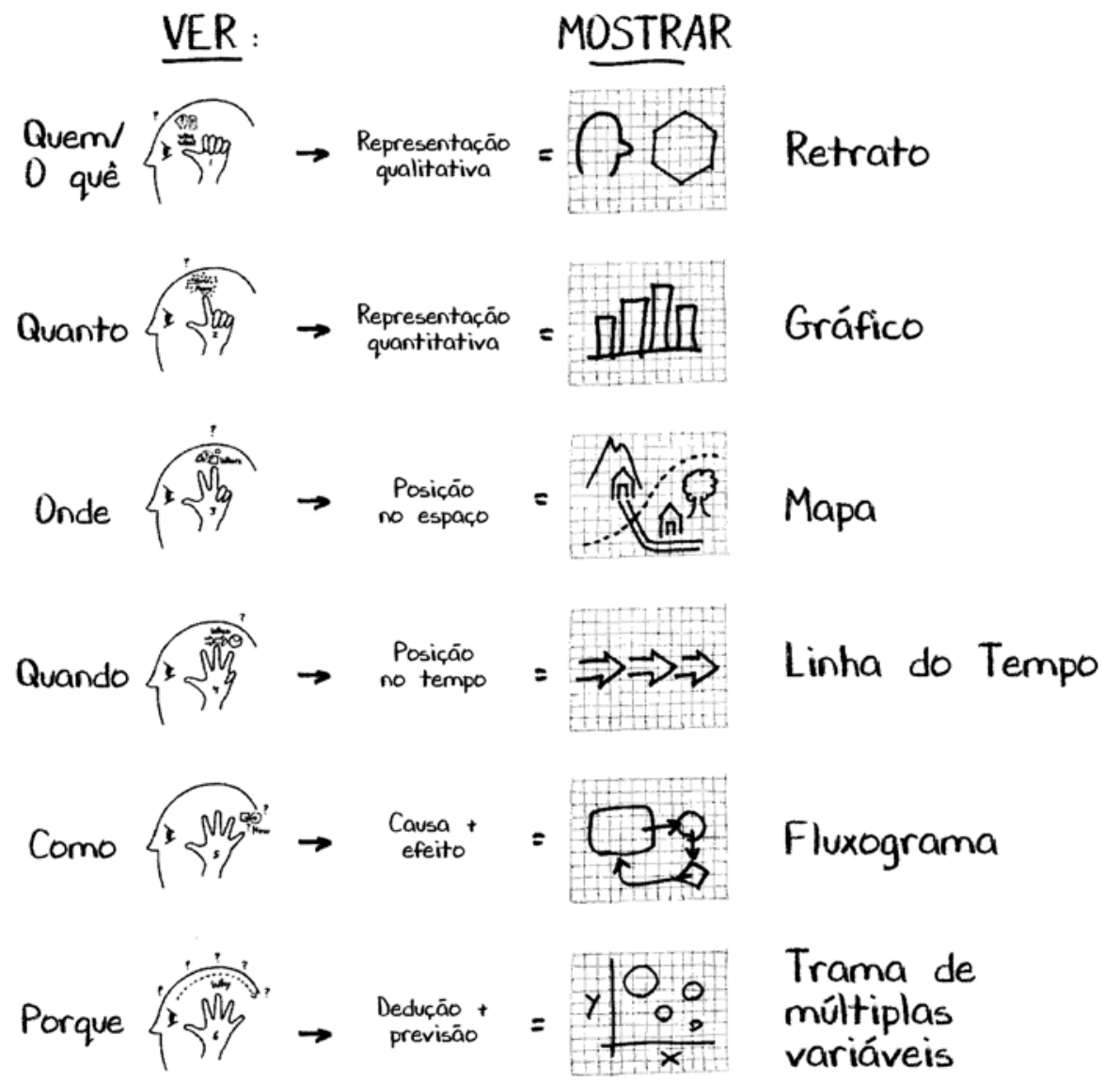

Fonte: Tradução e adaptação nossa de Roam, 2008, p.136.

No âmbito do jornalismo, Kanno (2013, p.148) identifica aqueles que seriam os recursos gráficos mais adequados para cada tipo de conteúdo textual, fornecendo orientações para seu melhor aproveitamento (Quadro 3) ${ }^{24}$.

\footnotetext{
${ }^{24}$ Kanno (2013, p.72;58) salienta que os critérios iniciais para a seleção de um formato gráfico são o tema (assunto) da matéria e a abordagem (enfoque) das imagens: "Começar pela forma é um erro, pois pode fazer com que o conteúdo seja distorcido ao ser adaptado".
} 


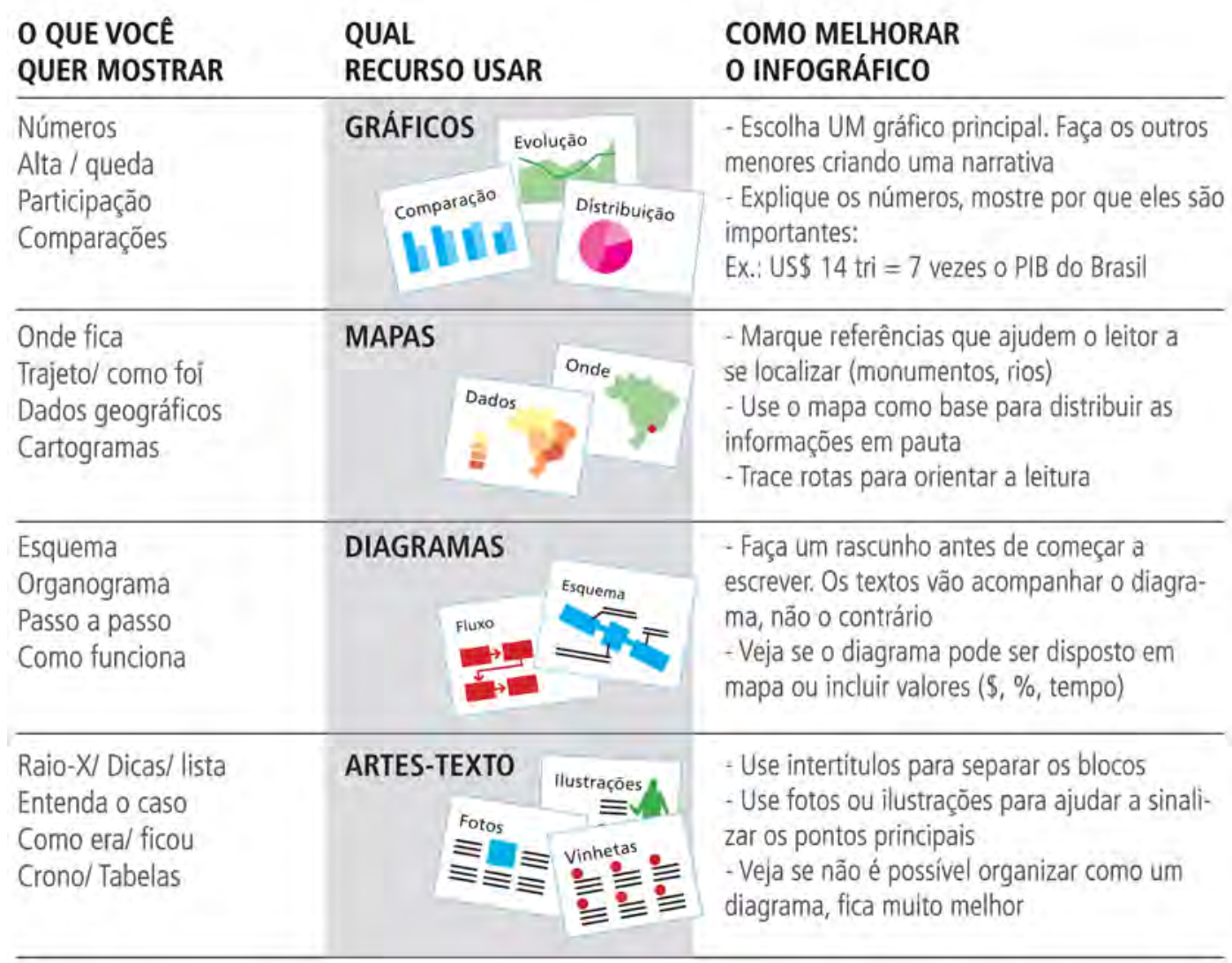

Fonte: Kanno, 2013, p.148.

Nas classificações supracitadas de Roam e Kanno, coincidem as categorias mapas (para representar posições no espaço) e gráficos (para representações quantitativas). Os itens linha do tempo, fluxograma e tramas de múltiplas variáveis (propostas por Roam para indicar, respectivamente, os quandos, comos e porquês) são agrupadas por Kanno em diagramas. Já retratos pode englobar ilustrações como cortes anatômicos e outros tipos de desenhos informativos (incorporados à categoria artes-texto).

Para Tufte (2007, p.15), a “excelência gráfica” é geralmente multivariável, sendo apresentada por meio de alguns formatos fundamentais: mapas de dados, linhas do tempo, narrativas espaço-temporais e gráficos relacionais.

Um gráfico relacional (equivalente à categoria tramas de múltiplas variáveis em Roam) é a representação duas ou mais variáveis de forma a permitir a visualização de evidências sobre causa e efeito, demonstrando como uma variável afeta outra. Pode conjugar grandes quantidades de in- 
formação de forma organizada e compreensível, havendo evidências de que o formato é assimilado por crianças de doze anos (BAMBERGER apud TUFTE, 2007, p.82). Um exemplo são os gráficos de dispersão (scatterplots), bastante utilizados por Hans Rosling, médico sueco que ganhou popularidade mundial, principalmente a partir de 2006, com vídeos nos quais expõe dados estatísticos de relevância social de forma visual e envolvente. No site de sua Fundação Gapminder ${ }^{25}$, por exemplo, o visitante pode observar as relações entre saneamento, renda, nutrição e saúde, fazendo comparações entre diferentes países ou regiões e verificando as tendências ao longo de determinados períodos (SHANKAR, 2015, p.76).

Tomando como base as três classificações de Tufte, Roam e Kanno, identificaremos os infográficos de nosso corpus de análise conforme as seguintes categorias: retrato (como cortes anatômicos e outros tipos de ilustrações informativas), gráfico (de barras, de linha, de pizza, de área, entre outros), mapa de localização, sequência ilustrada (passo a passo, fluxograma), linha do tempo, organograma, quadro comparativo e gráfico relacional.

$\overline{25}$ Disponível em: <http://www.gapminder.org>. Acesso em: 2 jul. 2017. 


\section{2 \\ PRINCÍPIOS E DIRETRIZES}

Quais os parâmetros para que um infográfico seja considerado bom e eficiente? Como garantir que a mensagem alcance o receptor, seja adequadamente compreendida e produza conhecimento? Deve-se trabalhar com objetividade e clareza, submeter os dados à análise precisa, e apresentá-los de forma “inteligente e atraente” (RENDGEN, 2012, p.14, tradução nossa).

McCandless, jornalista de dados britânico, propõe um diagrama (Figura 18) no qual identifica quatro quesitos essenciais para uma boa visualização: a informação (dados) assegura a integridade; a história (conceito) conduz ao interestingness (neologismo que poderia ser traduzido como

\section{Figura 18. Infográfico 0 que faz uma boa visualização?}

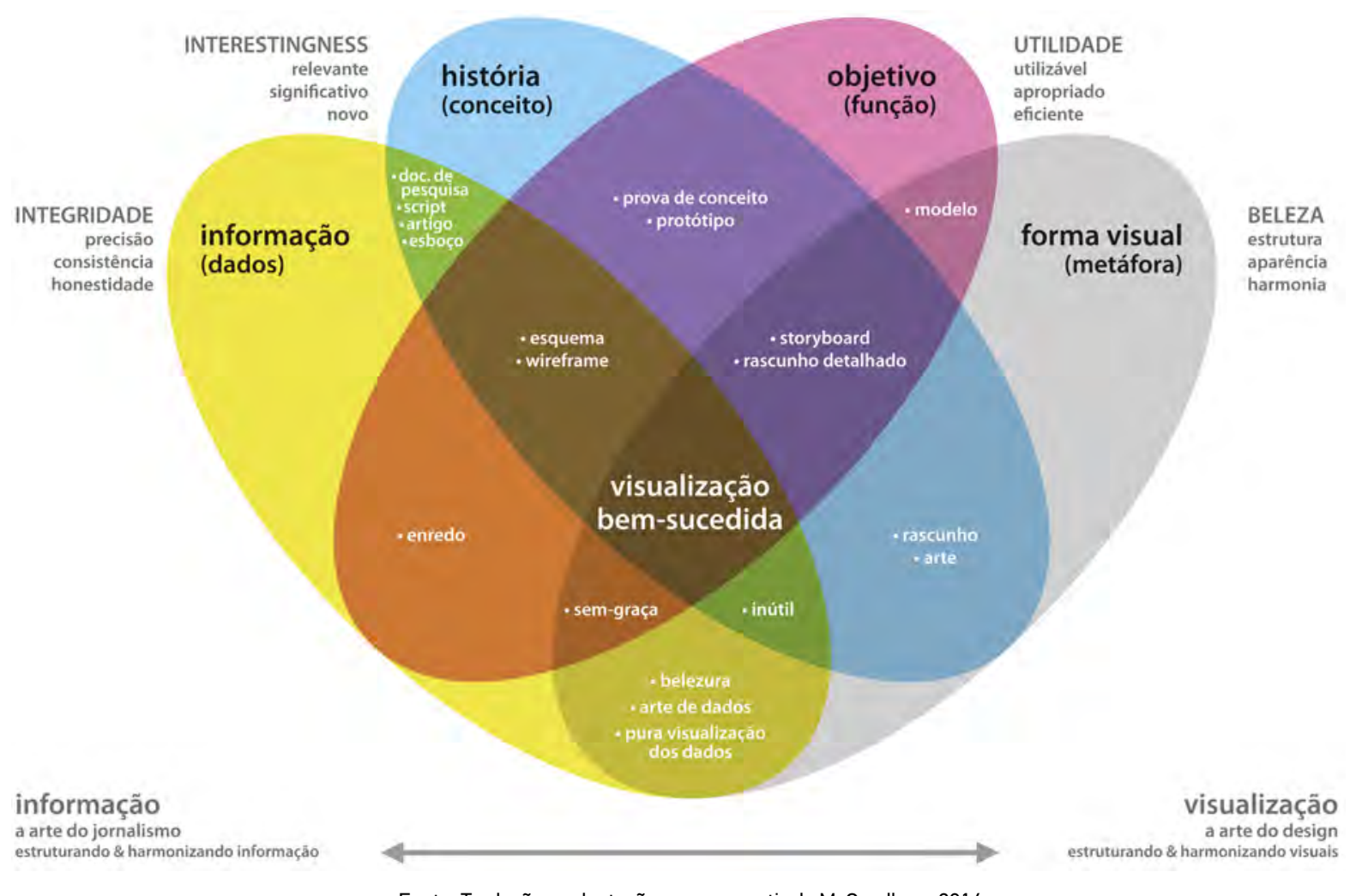

Fonte: Tradução e adaptação nossa a partir de McCandless, 2014. 
'qualidade do que é interessante'); o objetivo (função) indica a utilidade; e a forma visual (metáfora) norteia questões de estética. Segundo o autor, esses elementos formam a "espinha dorsal" de seu processo de criação, e um projeto será bem-sucedido apenas se atender a todos os quatro itens. Caso atenda somente a três, o resultado final será "estranhamente faltante", gerando um gráfico sem-graça, inútil, ou que não passa de um esquema ou storyboard. E caso o projeto atenda apenas a dois itens, o resultado não passará de uma "belezura", prova de conceito, rascunho, modelo, enredo ou esboço (McCANDLESS, 2014).

Já o reconhecido projetista gráfico holandês Mijksenaar organiza as funções do design em três princípios, evocando o arquiteto romano Vitruvius que, no séc. I a.C., havia estipulado que a arquitetura devia satisfazer aos seguintes critérios:

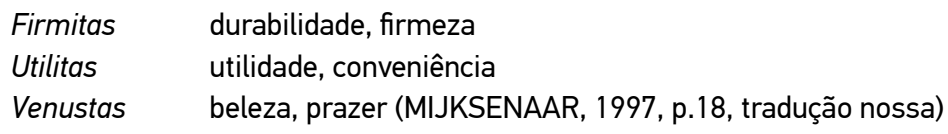

Por conseguinte, Mijksenaar define como elementos compositivos do bom design: a utilidade, a confiabilidade e a satisfação.

Para a análise de nosso corpus, decidimos assumir esses três princípios propostos por Mijksenaar por acreditarmos, com base em uma variedade de autores, que no âmbito do Design da Informação um projeto eficiente apresenta o conteúdo de forma:

a) compreensível e esclarecedora (CAIRO, 2013, p.17; FRASCARA, 2011, p.12; HORN, 2000, p.15; JACOBSON, 2000, p.02; MAEDA, 2006, p.36; McCANDLESS, 2010; RENDGEN, 2012, p.97; ROAM, 2008, p.116; TUFTE, 2007, p.51; WURMAN, 1991, p.104) - correspondendo à utilidade;

b) precisa, sem distorções ou equívocos (CIUCCARELLI, 2012, p.82; FRASCARA, 2011, p.21; McCANDLESS, 2009; RENDGEN, 2012, p.12; ROAM, 2008, p.225; TUFTE, 2007, p.51) - correspondendo à confiabilidade;

c) visualmente atraente (CAIRO, 2013, p.23; CIUCCARELLI, 2012, p.80; FRASCARA, 2011, p.14; HOLMES, 2012; MCCANDLESS, 2010; TUFTE, 2007, p.177; WURMAN, 1991, p.145) - correspondendo à satisfação. 


\subsubsection{UTILIDADE}

O primeiro item na declaração de filosofia da empresa Google revela: "Foque no usuário e todo o resto seguirá" (GOOGLE, s.d.). A eficácia de qualquer projeto de comunicação depende primordialmente de sua adequação ao usuário, tornando essencial que se examine esse usuário de forma aprofundada, respeitando os modos como ele processa e reage aos diferentes tipos de informação (PASSINI, 2000, p.85). Comunicar é “lembrar como era quando não se sabia” (WURMAN, 1991, p.138), observando aquilo que não faz sentido para o leigo (MAEDA, 2006, p.36).

A noção de design centrado no usuário dialoga com a intencionalidade pragmática do Design da Informação, cujo propósito não é a produção de objetos, mas a geração de reações desejadas nas pessoas. É um “design ético", porque implica na aceitação do usuário como diferente de si, com pensamentos, opiniões e desejos próprios. Isto envolve uma mudança da ideia de usuário como receptor, para outra de usuário como "sócio", acarretando num trabalho de parceria (FRASCARA, 2011, p.23-24, tradução nossa).

\subsubsection{1 - Contextualização}

Usuários acessam informações sob influência de suas próprias “histórias pessoais" (FRASCARA, 2011:16), assimilando as mensagens quando conseguem relacioná-las às suas memórias e experiências (CAIRO, 2013, p.17). Os mesmos dados que, para um cientista, são mais uma peça para "acrescentar a um já conhecido quadro de conhecimento", para o leigo não passam de fragmentos isolados de informação, "quase sem significado" (LAWRENCE, 2006, p.30, tradução nossa). Ao apresentar novos dados, é benéfico contrapô-los a outros já conhecidos pelo público, que somente compreenderá uma informação nova se esta estiver relacionada a algo que tenha sido assimilado previamente (FRASCARA, 2011, p.48; WURMAN, 2012, p.40). Na Figura 19, exibida no site da NASA, o mape-

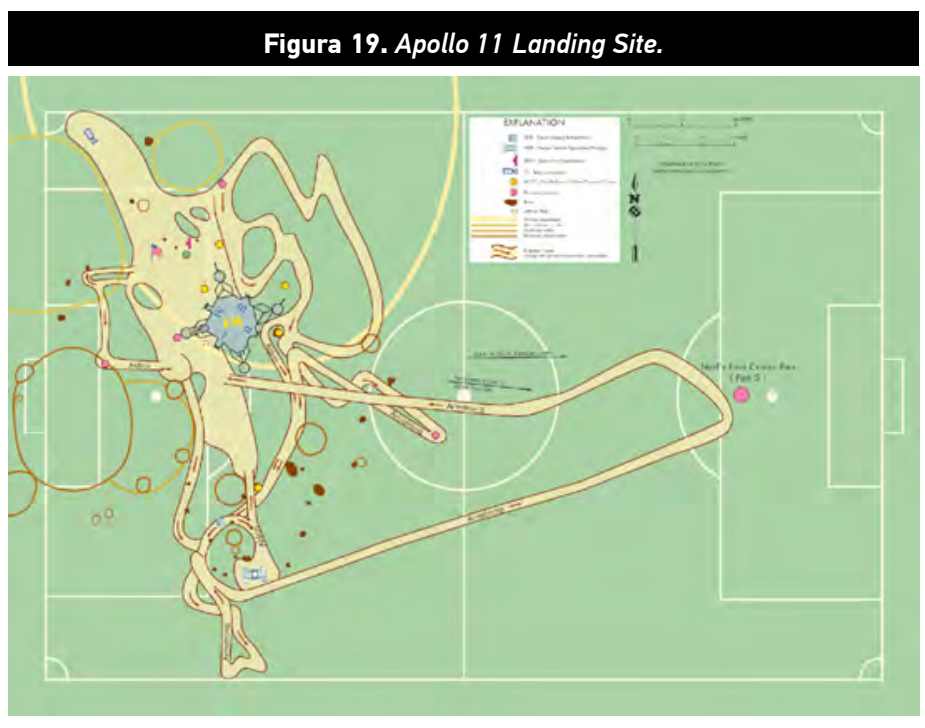

Fonte: NASA, 2012. 
amento dos primeiros passos humanos na Lua foi sobreposto à representação de um campo de futebol. Contrapondo-se uma grandeza distanciada do repertório do leitor (a área explorada na superfície lunar) a uma grandeza muito mais familiar, o conjunto favorece a compreensão. "Ao compararmos o dessemelhante, aguçamos o significado de ambos os opostos. 0 contraste é um caminho fundamental para a clareza do conteúdo em arte e comunicação" (DONDIS, 2007, p.119).

Altos valores monetários também costumam parecer bastante abstratos. Um gasto de $\mathrm{R} \$ 10$ bilhões em um avião presidencial, por exemplo, será mais facilmente compreendido se for comparado com outros investimentos do governo, ou à quantidade de passagens que poderiam ser compradas com o valor (KANNO, 2013, p.75;117). Semelhantemente, escalas e unidades de medida, como Fahrenheit, Richter ou hectares, podem carregar um grau de hermetismo.

Tomemos como exemplo a cobertura do acidente ocorrido em uma mina de cobre no Chile em 2010, no qual 33 trabalhadores foram soterrados a 688 metros de profundidade. A equipe de resgate perfurou um poço, pelo qual passaria a cáp-

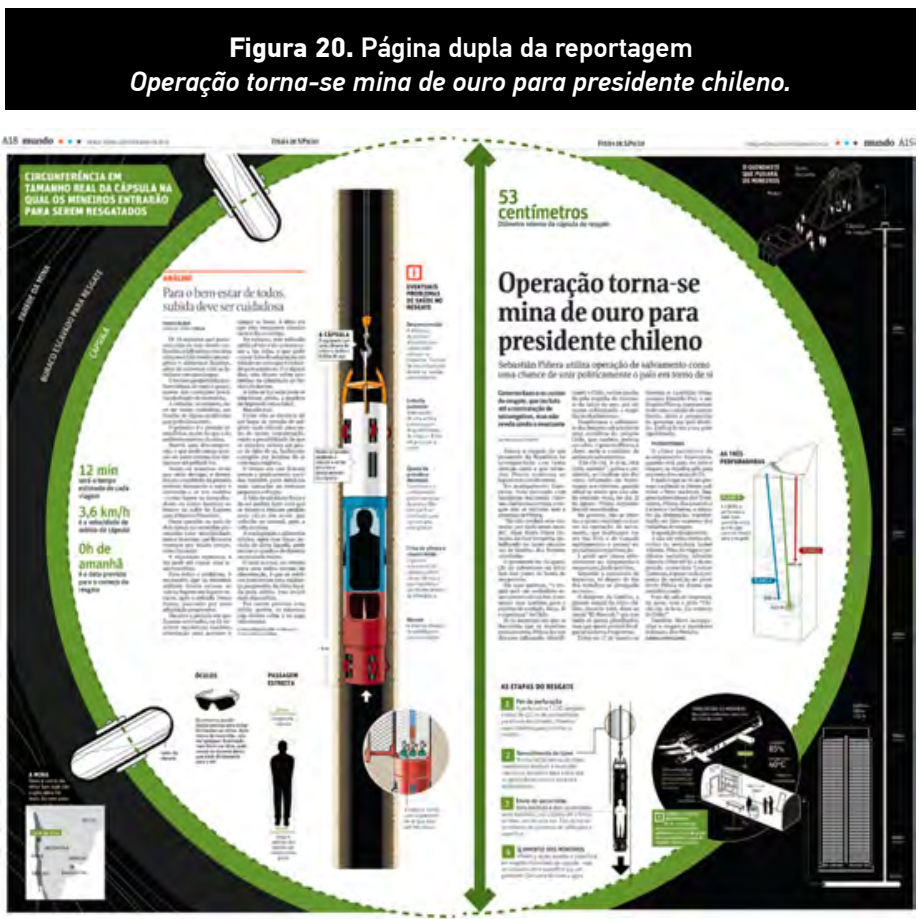

Publicado em: Folha de S.Paulo (12 out. 2010). Fonte: Capriglione, 2010. sula Fenix II, um compartimento metálico que traria cada um dos mineiros individualmente à superfície. Para facilitar a compreensão das circunstâncias em que se deu a operação, a versão impressa da Folha de S. Paulo incluiu, em uma reportagem de página dupla, um círculo que indicava, em tamanho real, os $53 \mathrm{~cm}$ de diâmetro interno da cápsula (Figura 20).

Clareza e lucidez são também propiciadas pelo emprego elementos intuitivos de reconhecimento imediato. Esse senso de familiaridade é frequentemente assegurado pelo uso de metáforas, recursos que representam seu objeto por similaridade a fim de favorecer a compreensão de novas ideias, ao aplicar conceitos previamente assimilados (MARTíN, 2007, p.84) e tirar proveito do "terreno comum" entre emissor e receptor (KONG, 2006, p.221). Exemplo clássico são os íco- 


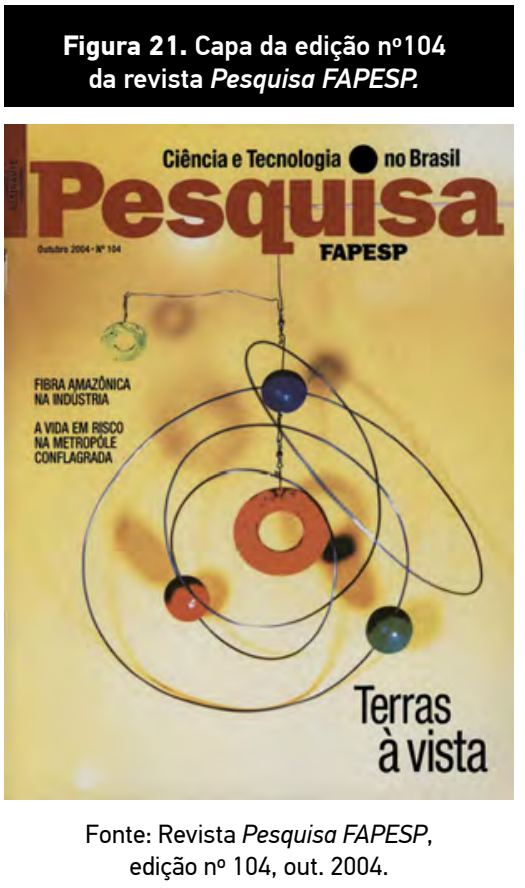

nes das áreas de trabalho (desktops) de interfaces digitais, que remetem a um ambiente físico de trabalho: pastas contendo papéis remetem às pastas que armazenam arquivos de dados, enquanto um cesto de lixo remete ao destino virtual para os dados deletados (MAEDA, 2006, p.39-40).

Para a Divulgação Científica, a proficuidade do recurso metafórico é evidenciada na representação de conceitos hipotéticos. Um exemplo é a imagem de um objeto montado com arame, semelhante a um móbile (Figura 21), na capa da edição no 104 (out/2004) da Pesquisa FAPESP. A matéria a que a imagem se refere trata de pesquisas em astrofísica e da busca por exoplanetas com características semelhantes à da Terra. Como forma de suprir a dificuldade

do registro fotográfico de tais corpos celestes, a editoria de arte da revista recorreu às representações artísticas, "as únicas capazes de manter as descobertas no nível de hipóteses" (MACHADO, 2016, p.117). Dessa forma, a metáfora convoca "não o silogismo, mas a imaginação especulativa" (MACHADO, 2016, p.128).

Por outro lado, uma visualização também não será eficaz se o conteúdo informativo estiver incompleto, impedindo o real domínio dos fatos. É importante fornecer elementos que contextualizem a mensagem. Tufte defende que o design definhado, escasso em dados deve ser evitado, pois gráficos "frequentemente mentem por omissão, deixando de fora dados suficientes para comparações" (TUFTE, 2007, p.74, tradução nossa).

No infográfico Tracking Carbon Emissions (Figura 22), a comparação entre dois conjuntos de dados relacionados, porém distintos, evidencia informações que de outro modo poderiam ser despercebidas. A imagem indica as emissões de $\mathrm{CO} 2$ por cerca de 200 países, de forma que as quantidades são representadas pelo tamanho das bolhas respectivas. 0 conjunto à esquerda refere-se à quantidade absoluta de emissões por país, com a China e os EUA correspondendo aos maiores emissores. Já o conjunto à direita exibe a relação entre emissões e população, resultando numa imagem bastante diferente. Algumas nações pequenas como Gibraltar e llhas Virgens lideram a lista por necessitarem importar muitos bens por navio, o que por consequência aumenta suas emissões per capita (RENDGEN, 2012, p.467). 


\section{Tracking Carbon Emissions}

A footprint comparison of total carbon dioxide emissions by nation and per capita shows there's plenty of room for smaller countries to reduce their carbon footprints. By Stanford Kay

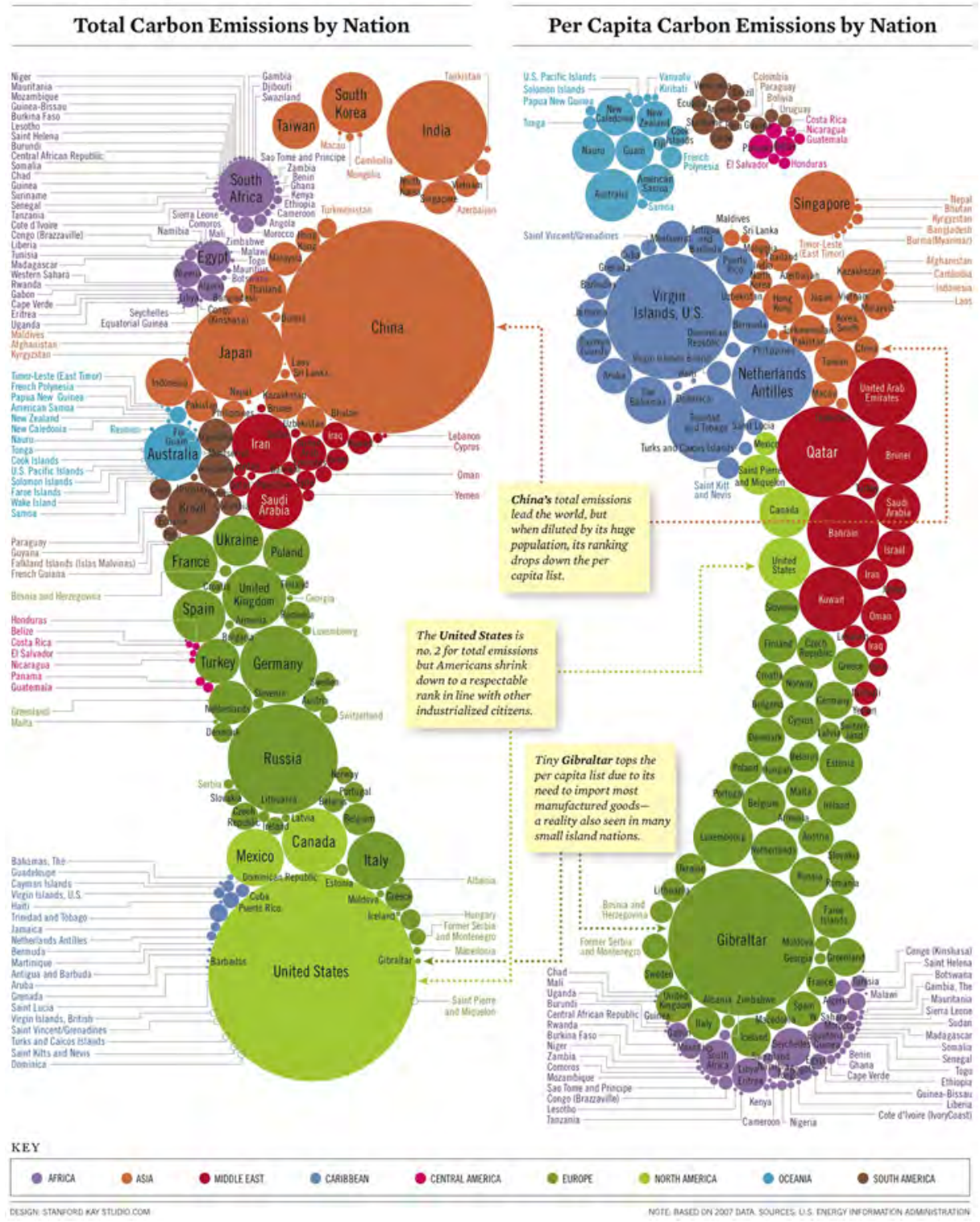

Infográfico de: Stanford Kay. Fonte: Miller-McCune, 2010.

\subsubsection{2 - Organização e conforto}

Essencial no processo de transmissão de mensagens é o conforto do receptor. Não há proficuidade, por exemplo, no fornecimento de grandes volumes de informações concomitantes. Em The Magical Number Seven, Plus or Minus Two, artigo largamente citado no âmbito da psicologia, Miller (1956) defende que as pessoas conseguem acumular na memória sete unidades de informação 
(duas a mais ou duas a menos, dependendo de uma série de fatores). Para a comunicação de massa é aconselhável não exceder cinco unidades de informação em uma única mensagem. 0 autor sugere o agrupamento: ao fornecer vinte unidades de informação, por exemplo, o ideal é organizá-las, de forma lógica e compreensível, em 5 grupos de 4 unidades, ou em 4 grupos de 5. Agrupamentos auxiliam o usuário no gerenciamento das informações, e consequentemente na sua assimilação e memorização (MILLER, 1956).

0 nível de esforço cognitivo é reduzido significativamente quando a estrutura de organização do projeto se evidencia por um sistema visual bem definido (FRASCARA, 2011, p.22-25). Wurman (2012, p.40) defende que o alfabeto é o único princípio organizacional que precisamos aprender conscientemente. Todos os outros seriam inatos à espécie humana, que categoriza espontaneamente aquilo que vê, conforme os mecanismos cerebrais de formação de padrões identificados no âmbito da psicologia gestaltista (citada anteriormente).

Para que a estrutura de organização de um projeto gráfico seja identificável, os elementos devem ser visualmente coerentes, e as convenções gráficas constantes ao longo da obra. Desta forma, o leitor "aprende o vocabulário visual", hierarquiza as mensagens, e pode conduzir a leitura com eficácia, conforto e segurança, economizando "tempo e carga cognitiva" (FRASCARA, 2011, p.27, tradução nossa):

\footnotetext{
“Em aprendizagem, isso se chama 'priming' em inglês: a função de preparar o leitor para compreender um texto [...]. Se a pessoa sabe qual é o propósito do texto que está para ler, quais são suas convenções visuais, e quais são seus elementos essenciais, será mais fácil compreender seu conteúdo."
}

(FRASCARA, 2011, p. 27, tradução nossa)

Massironi (2002, p.196-198) identifica etapas evolutivas na organização visual das representações científicas. Como exemplo, toma dois registros documentais sobre o desenvolvimento de formas vivas. 0 primeiro caso, elaborado em 1675 (Figura 23), descreve o ciclo de vida de um mosquito através de ilustrações dos diferentes estágios do inseto, dispostas numa mesma página e de forma aleatória. A sequência temporal é identificada por rótulos numéricos, ao invés de um arranjo espacial ordenado. Já o segundo exemplo, de 1774, indica uma conscientização da organização narrativa. A imagem retrata as rápidas transformações morfológicas sofridas por uma ameba através de uma série de ilustrações que são diagramadas sequencialmente da esquerda para a direita e de cima para baixo (Figura 24). 


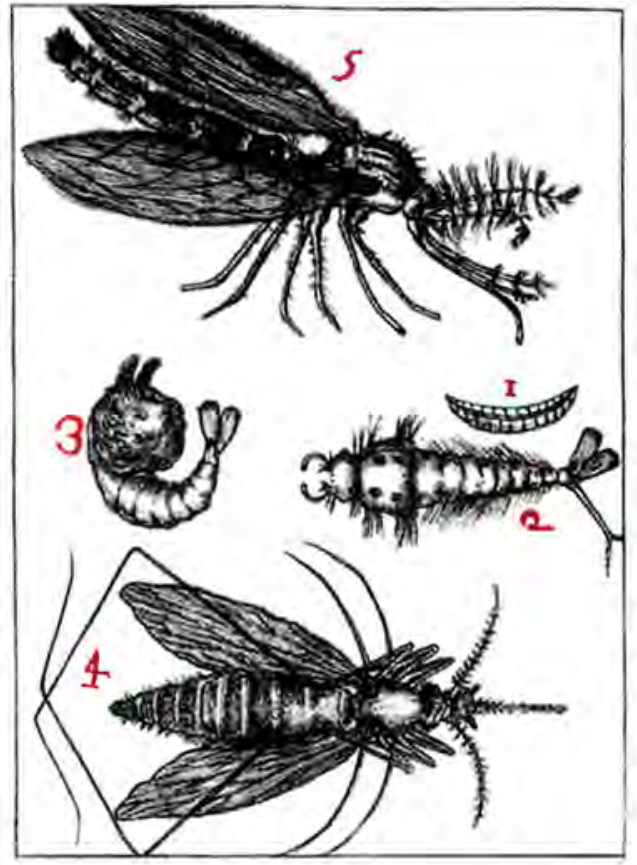

llustrado por Pietro Paolo da Sangallo em 1675. Fonte: Massironi, 2002, p.197.

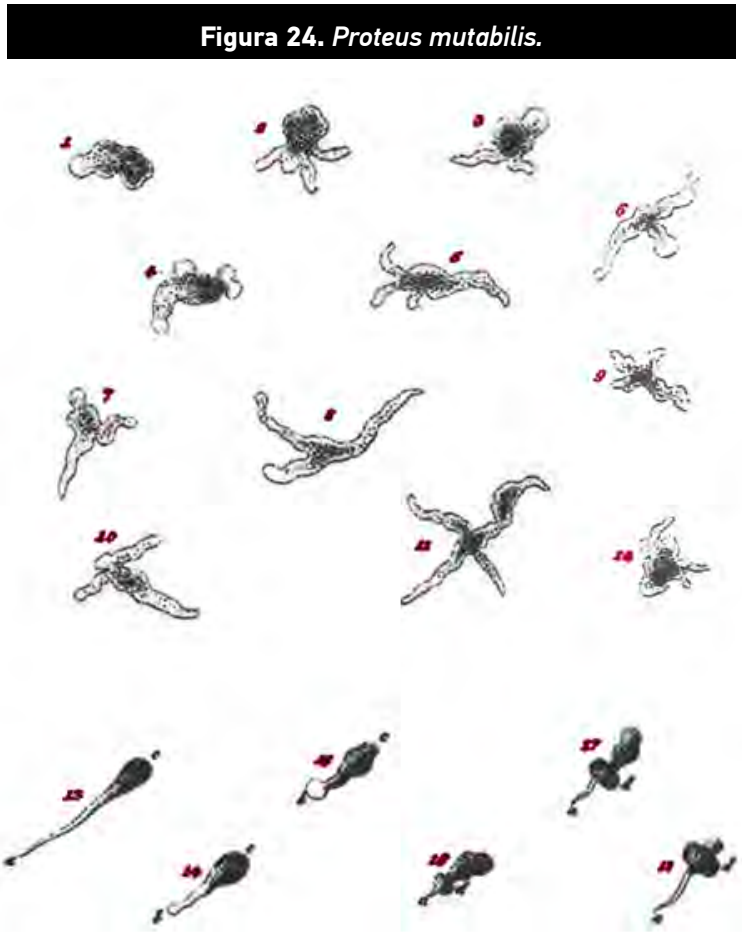

Ilustrado por F. Müller em 1774. Fonte: Massironi, 2002, p.198.

Ponderação e pontos de respiro também são essenciais para evidenciar hierarquias (VIGNELLI, 2009, p.92). A funcionalidade da composição deriva do uso adequado de ritmo, que pode ser obtido por meio da "alternação ou variação no emprego de recursos visuais gráficos como tamanho de parágrafos, ênfases para destacar assuntos mais importantes dos secundários, espaços brancos para descansar a vista, etc." (SOUZA; SCHMID, 2009, p.17).

\subsubsection{CONFIABILIDADE}

Toda representação visual de dados decorre de uma interpretação, e é responsabilidade do designer manuseá-los com diligência, examinando as relações entre causas e efeitos cautelosamente (FRASCARA, 2011, p.21) e estando "plenamente consciente da intencionalidade do artefato de comunicação" (CIUCCARELLI, 2012, p.82, tradução nossa). 
“Números bem torturados dizem qualquer coisa”, brincam os estatísticos. É assim que um mesmo relatório que aponta um aumento da mortalidade entre 2015 e 2017, por exemplo, pode também indicar uma queda da mortalidade de 2016 a 2017. Nem é preciso manipular os dados: basta interpretá-los de forma conveniente ao discurso desejado.

Principalmente desde a década de 1950, diversos autores como Tukey, Bertin e Tufte têm analisado a questão da precisão na representação gráfica. Em How to Lie with Statistics, Huff (1954) observou numerosos casos, provenientes da publicidade e de outros meios de comunicação, nos quais informações estatísticas eram apresentadas de forma distorcida para favorecer opiniões tendenciosas. Sua crítica era principalmente contra gráficos desprovidos de legendas ou com dados insuficientes para permitir uma avaliação adequada (RENDGEN, 2012, p.12).

A produção infográfica conduzida diligentemente promove aquilo que Tufte (2007) denomina “integridade gráfica”. Como exemplo, o autor apresenta a Figura 25-A, na qual estão indicadas as quantidades de mortes no trânsito do estado de Connecticut (EUA) antes e depois da adoção de uma política mais rigorosa em relação à velocidade. 0 gráfico parece completo, mas um histórico mais abrangente acrescentaria à compreensão do cenário (Figura 25-B). Em diferentes contextos, as interpretações para o gráfico poderiam variar drasticamente (Figura 25-C). A comparação com estados adjacentes possibilita uma visão ainda mais completa, revelando que não foi apenas Connecticut que obteve um declínio nas fatalidades de trânsito no mesmo período (Figura 25-D).

Figura 25. Queda da quantidade de mortes no trânsito em Connecticut.

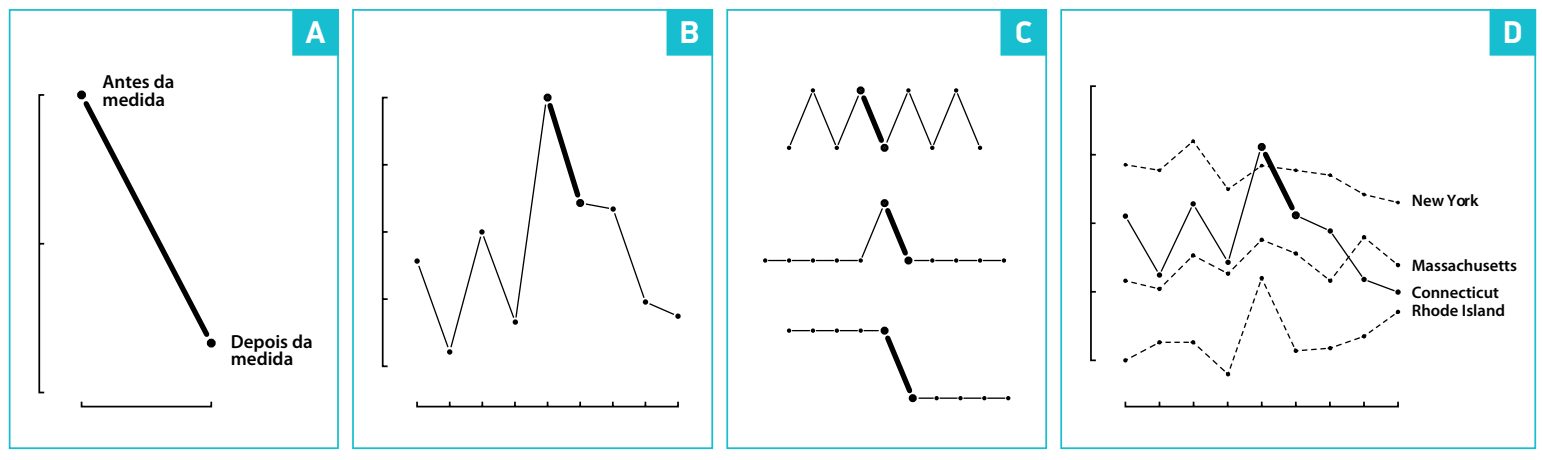

Fonte: Tradução e adaptação nossa de Tufte, 2007, p.74-75.

\subsubsection{1 - Integridade gráfica}

O infográfico Matéria-prima extraída do interior das plantas (Figura 26-E), publicado pela Pesquisa FAPESP, retrata um procedimento de extração de nanocristais a partir de fibras vegetais, através de uma ilustração aparentemente simples. Mas pela observação das Figuras 26-A, 26-B, 


\section{Figura 26. Processo de aprovação do infográfico Matéria-prima extraída do interior das plantas.}
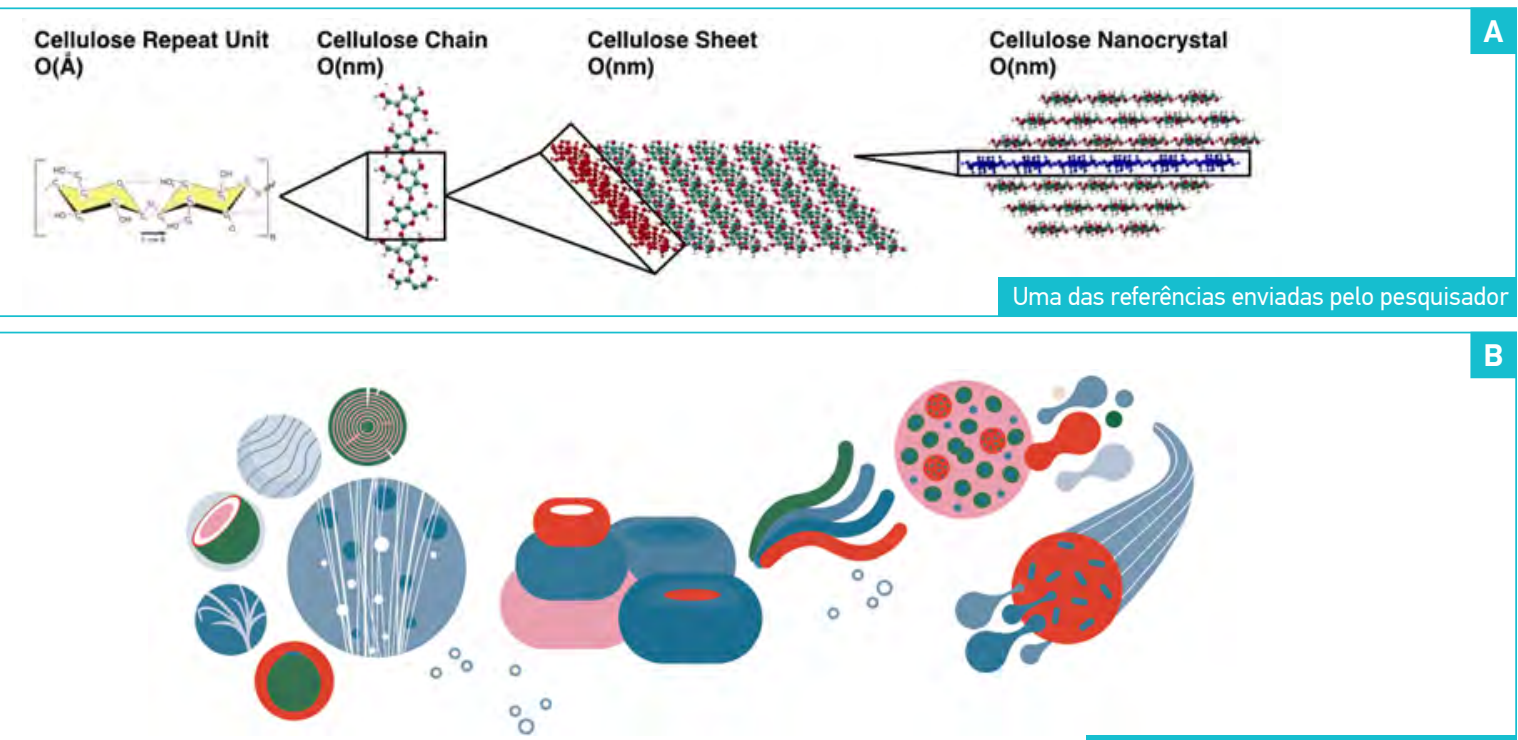

\section{Sequi omnis si raturet odia dolo}

Debis sit offici as di consed millend aeratur Pel moluptas undis quam, culparum

EXTRAČ̃̃O DOS

NANOCRISTAIS DE

CELULLOSE

Toressecatem qui

conectet undit hit

que comni abo.

Nequia quid experia

Nequia quid experia

FONTE NONONONON
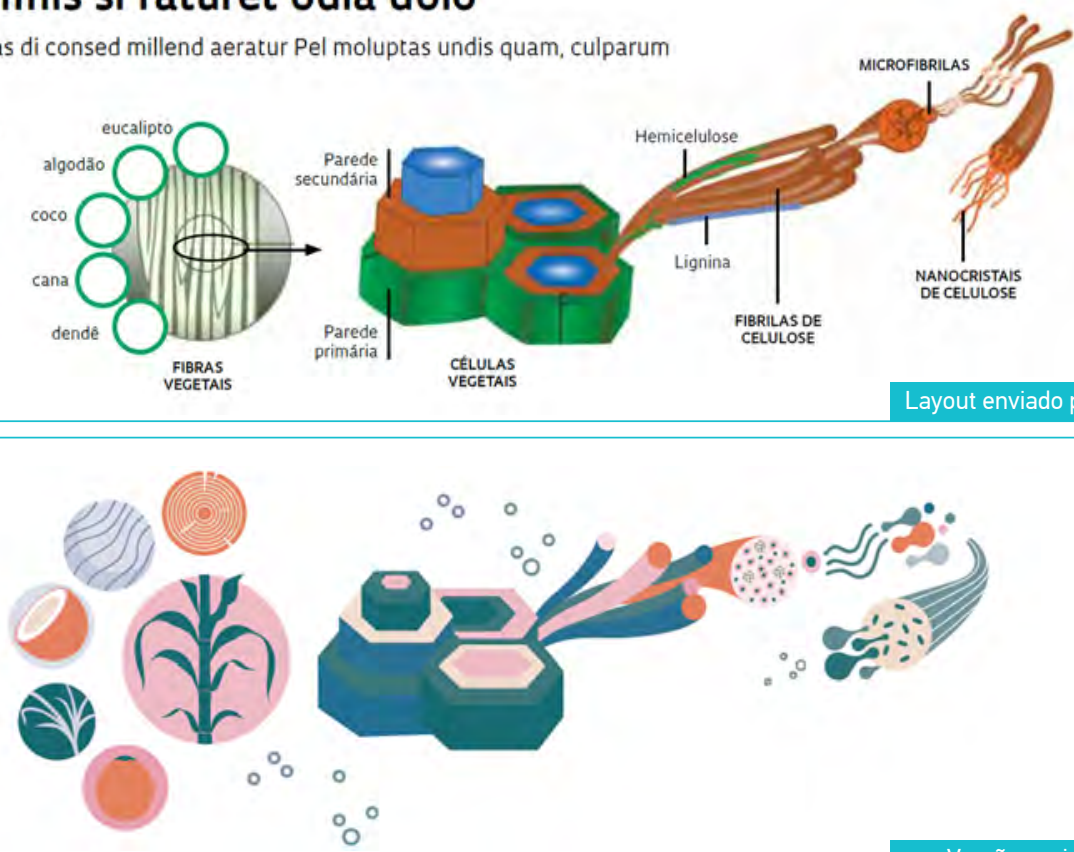

\section{Matéria-prima extraída do interior das plantas}

Novo material é gerado a partir da celulose encontrada em grande parte dos vegetais
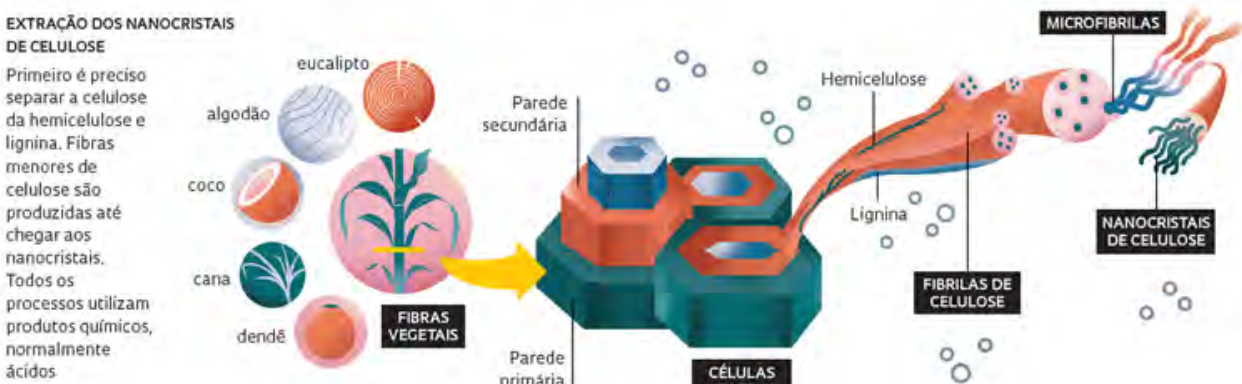

ácidos

$$
\begin{array}{r}
\text { Parede } \\
\text { primária }
\end{array}
$$


26-C e 26-D, percebe-se a complexidade do processo de criação do infográfico, que envolveu uma série de ajustes e validações por parte do pesquisador consultado. As versões iniciais não retratavam adequadamente as seções das células e fibrilas, nem permitiam a noção sequencial de que cada segmento ilustrado é um excerto do segmento anterior. Para corrigir o problema, a editoria de infografia solicitou ao ilustrador ajustes nas formas e na seleção de cores, que deveriam manter um padrão consistente ao longo da narrativa. Outra falha nas primeiras versões era a representação das paredes primária e secundária das células vegetais, que não estava clara, passando a ideia de três unidades independentes (ao invés de camadas sobrepostas).

Este exemplo também permite inferir que cada formato de gráfico apresenta características próprias que exigem ponderações específicas - retomamos aqui os diferentes formatos de infográficos que delineamos a partir de Tufte, Roam e Kanno na primeira parte deste capítulo.

No caso dos retratos e das sequências ilustradas (como esse infográfico sobre a extração de nanocristais), o risco reside na subjetividade envolvida no processo de representação pictórica. Na visão de Kanno (2013, p.113), ilustradores dificilmente trabalham desprovidos de noções pessoais preconcebidas. 0 autor cita um exemplo proveniente do jornalismo: após um massacre no campus da Universidade Virginia Tech, que vitimou 32 pessoas em 2007, a Folha de S. Paulo publicou uma sequência ilustrada dos acontecimentos. Entretanto, o assassino, que era um jovem asiático, foi retratado como um mulato. 0 equívoco suscitou protestos por parte dos leitores (KANNO, 2013, p.111), evidenciando o valor da imparcialidade do ilustrador e da apuração meticulosa das informações. Quanto mais na ilustração científica, que pressupõe pleno "compromisso com a verdade" (TROTTA; SPINILLO, 2016, p.261).

Mas formatos gráficos aparentemente neutros podem também camuflar o perigo da subjetividade. Num gráfico de linha, o aspecto do conjunto pode ser facilmente transfigurado, sem necessariamente haver uma manipulação dos dados. Proporções muito verticais ou muito horizontais podem criar uma "dramatização" da curva (KANNO, 2013, p.93), de forma que os mesmos dados podem gerar impactos visuais bastante distintos (FIGURA 27). Analogamente,

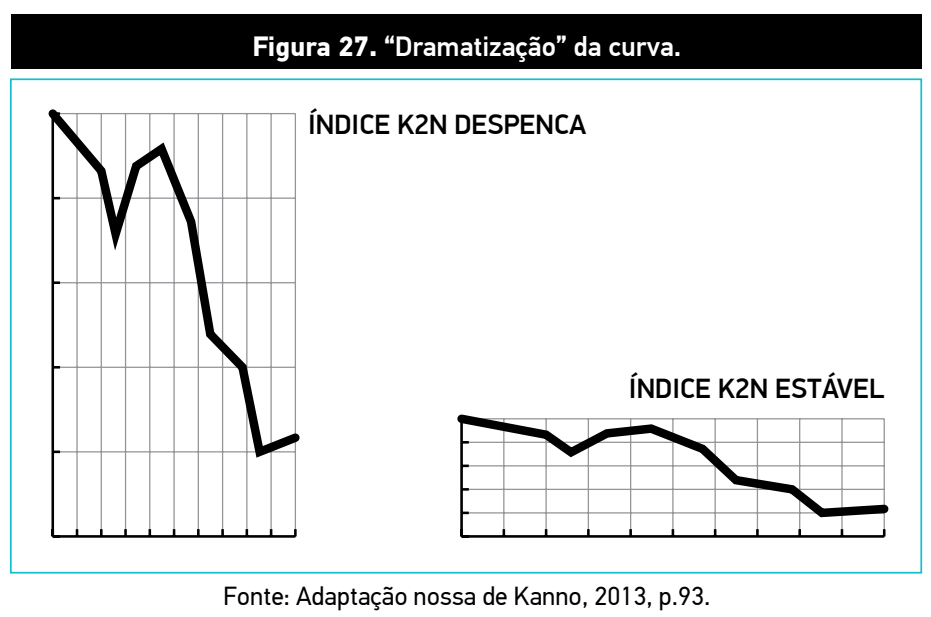


Figura 28. Distorção na velocidade da tendência.

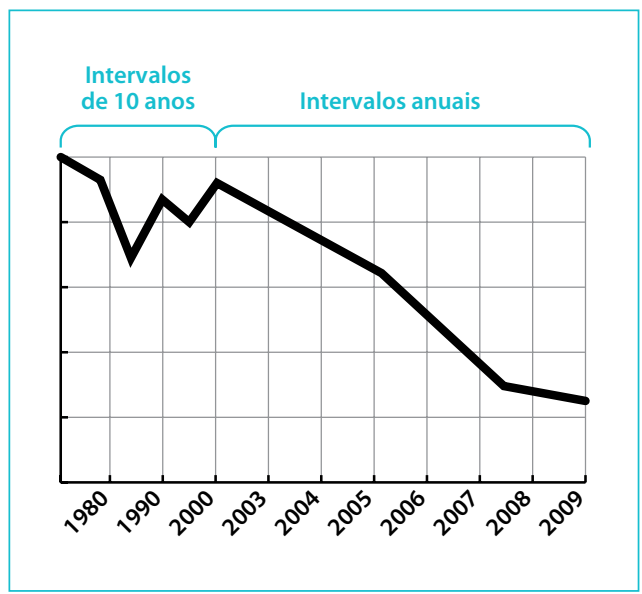

Fonte: Adaptação nossa de Kanno, 2013, p.95. caso os intervalos dos valores em qualquer um dos eixos ( $x$ ou $y$ ) não sejam regulares, haverá distorção na velocidade de tendências (Figura 28).

Se houver o emprego de cores, estas devem ser bem selecionadas para não confundir os leitores, inclusive aqueles com deficiência da visão de cor (5 a 10\% dos espectadores). 0 azul é diferenciado de outros matizes pela maioria das pessoas que apresentam dificuldade para reconhecer distinções cromáticas. Já o vermelho e o verde não devem ser usados para contrastes cruciais (TUFTE, 2007, p.183).

No gráfico da Figura 29, representando as quantidades de casos suspeitos de microcefalia no Brasil entre outubro de 2015 e fevereiro de 2016, a cor da linha relativa aos "Casos descartados" é muito próxima à cor relativa aos "Casos confirmados de microcefalia com zika", afetando sua diferenciação. Ademais, o gráfico apresenta outras falhas: a data final no eixo $x$ (provavelmente 22.02.2016) não é indicada; e algumas linhas parecem estar incompletas, posto que há três índices que são nomeados, mas não representados por linhas: 2, 102 e 134.

0 sistema informativo dos mapas de localização é também frequentemente baseado em cores, tornando crucial sua diferenciação. Na legenda do infográfico pertencente à matéria Um mapa do risco no mundo (reproduzido parcialmente na Figura 30), há seis categorias de vulnerabilidade a desastres naturais, que são identificadas cromaticamente. No entanto, os tons da segunda e quinta cores,

\section{Figura 29. Trecho do infográfico As conexões entre o zika e a microcefalia.}

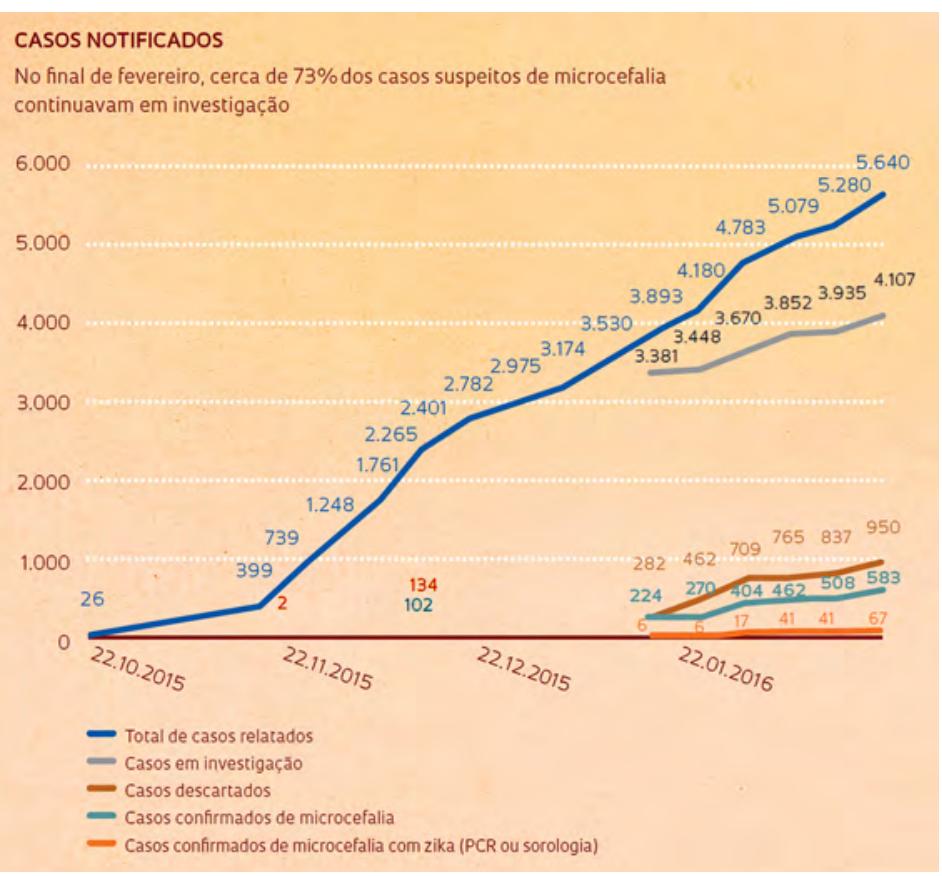

Fonte: Revista Pesquisa FAPESP, edição nº 241, mar. 2016. 


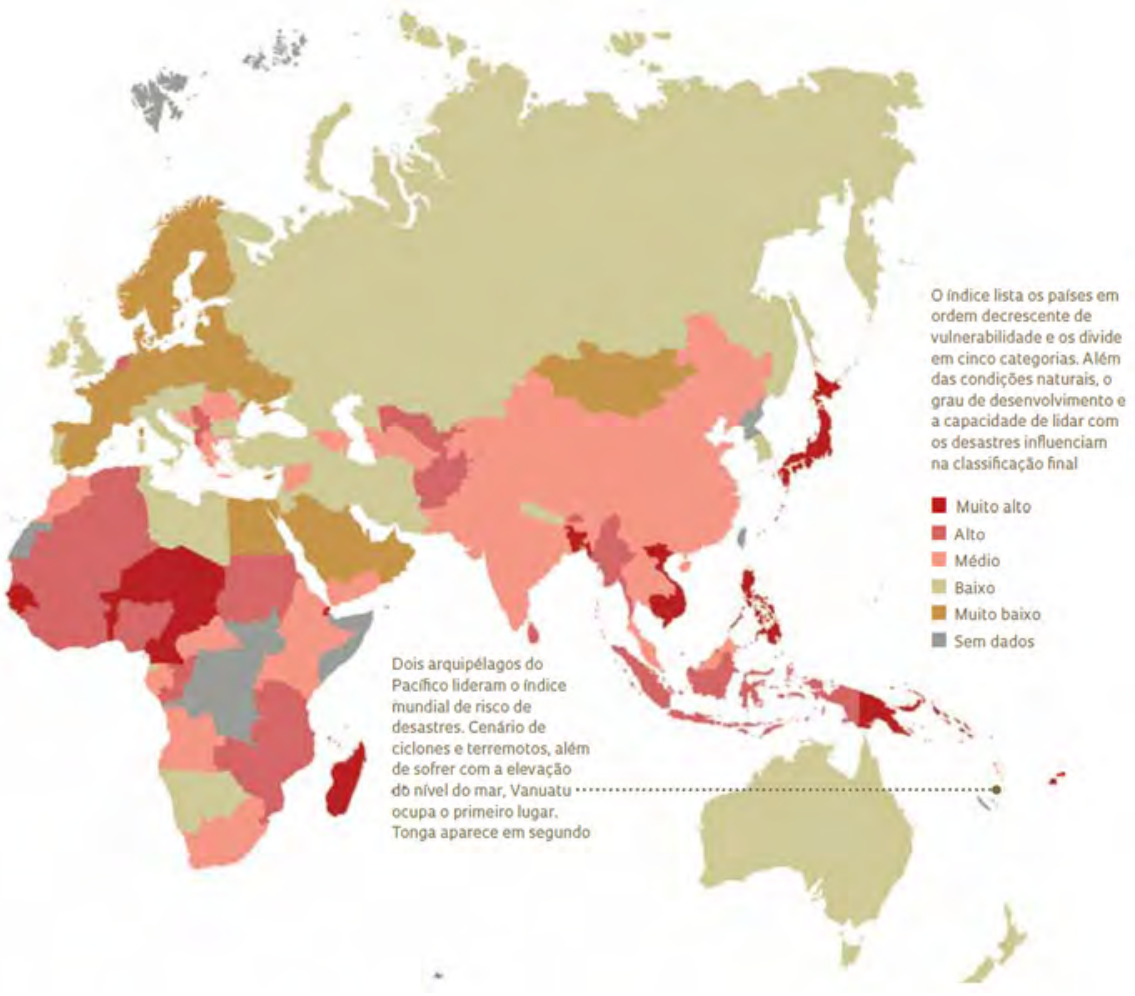

Fonte: Revista Pesquisa FAPESP, edição n 249 , nov. 2016.

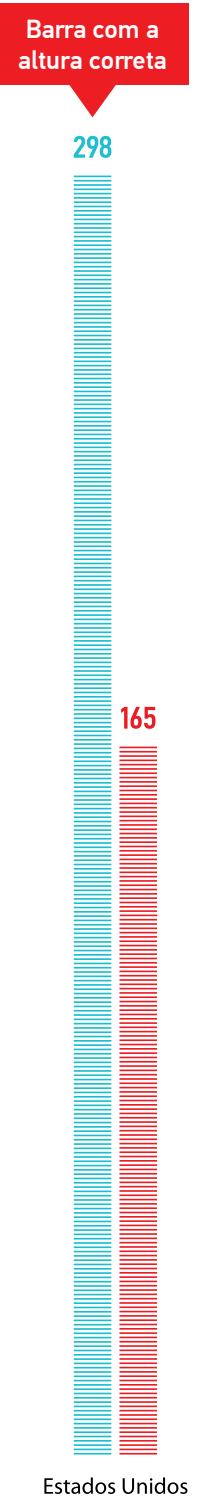

relativas a categorias bastante distintas ("Alto" e "Muito baixo"), são muito semelhantes, gerando dubiedade na leitura.

Num gráfico de barras, o valor informativo reside na evidência visual das diferenças de tamanho entre cada barra. Não raro, entretanto, barras mais compridas são "cortadas" para facilitar a diagramação na página. Este é o caso reproduzido na Figura 31, na qual a barra referente ao ano de 2006 nos Estados Unidos foi seccionada a 64,14\% de sua altura correta.

Figura 31. Trecho do infográfico Máquinas pelo mundo.

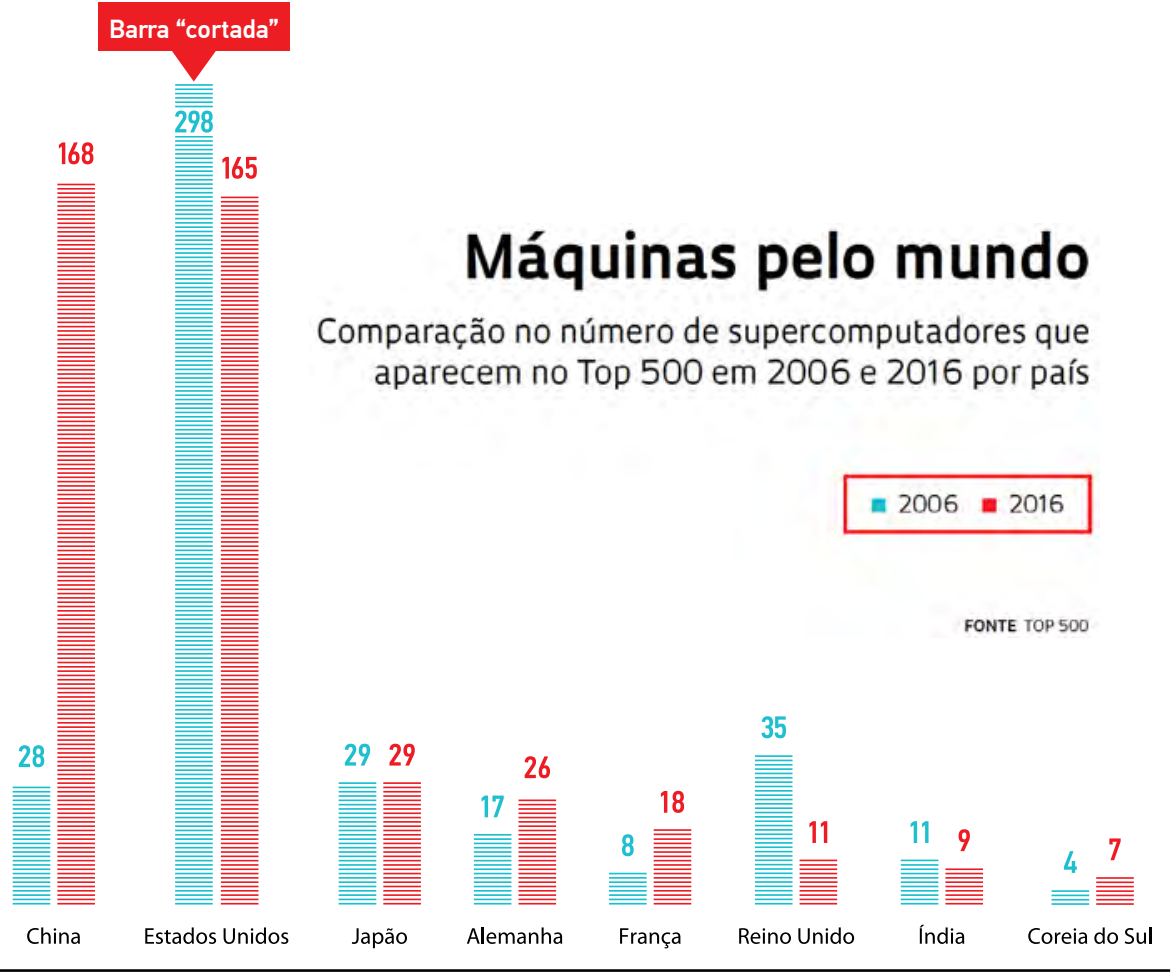

Fonte: Elaboração nossa. 
Um formato acerca do qual encontramos muita dissensão foi o gráfico de pizza. Por um lado, diversos pesquisadores (CLEVELAND, 1994; FEW, 2007; ROBBINS, 2005; TUFTE, 2007) condenam este formato devido à dificuldade humana para distinguir diferenças entre ângulos e, consequentemente, para comparar adequadamente o tamanho das "fatias" da pizza. A maioria das pessoas subestimam ângulos agudos (menores que $90^{\circ}$ ) e superestimam ângulos obtusos (maiores que $90^{\circ}$ ); além de perceberem ângulos com bissetores horizontais (quando a linha que divide o ângulo ao meio é horizontal) como maiores que ângulos com bissetores verticais (ROBBINS, 2005, p.49). Só temos facilidade para julgar a magnitude de uma fatia quando seu ângulo estiver próximo a $0 \%, 25 \%, 50 \%, 75 \%$ ou $100 \%$ (FEW, 2007, p.2).

Devido às distorções de leitura, Cleveland (1994, p.262-268) rejeita o gráfico de pizza e adota o termo pop charts (gráficos pop) para se referir ao formato e a outros modelos que não permitem detectar de forma eficiente informações sobre valores e que, portanto, são pouco empregados "em ciência e tecnologia", apesar de serem "amplamente utilizados na mídia de massa e em publicações de negócios" (CLEVELAND, 1994, p.262, tradução nossa).

Por outro lado, diversos profissionais (COLACIOPPO, 2014, KANNO26, 2013; WONG27, 2010), apesar de concordarem com algumas limitações do formato, defendem o uso do gráfico de pizza por permitir rápida e fácil visualização das divisões de um todo - $100 \%$.

Rebatendo o argumento de Few (2007, p.4) de que o uso de barras seja mais adequado para a representação da divisão de um todo por permitir a comparação dos tamanhos das partes entre si, Colacioppo (2014) defende que, neste formato, perde-se a noção clara de que as barras somam 100\%. Já no gráfico de pizza, "isso é indiscutível".

Wong (2010), inclusive fornece orientações quanto à distribuição das fatias no conjunto. Segundo a autora, lemos intuitivamente os gráficos de pizza como um relógio: no sentido horário, a partir das $12 \mathrm{~h}$. Sua diretriz é posicionar a maior fatia na região superior direita, para enfatizar sua importância. A segunda maior fatia deve ficar à esquerda das $12 \mathrm{~h}$; e as demais partes seguem no sentido anti-horário. Desta forma, a menor fatia ficará em posição menos significativa, próxima à área inferior (Figura 32). Wong também reconhece que uma

\footnotetext{
$\overline{26}$ Reconhecido como um dos pioneiros da infografia no Brasil, Mario Kanno cria, desde a década de 1980, infográficos para Folha de S.Paulo e Editora Abril. 27 Dona Wong foi aluna de Edward Tufte e posteriormente editora de gráficos para o The New York Times e o The Wall Street Journal.
}

Figura 32. Distribuição das fatias em um gráfico de pizza.

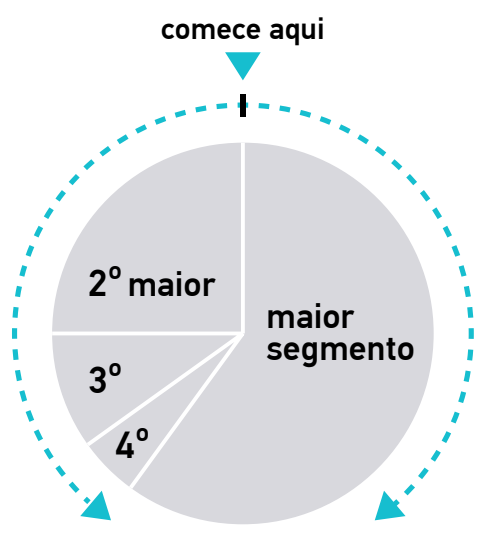

Fonte: Tradução e adaptação nossa de Wong, 2010. 
quantidade muito grande de fatias dificulta a leitura do gráfico, que não deve ter mais que cinco divisões. Se houver um número maior, o ideal é combinar fatias menores e menos relevantes numa quinta fatia denominada "outros".

Como mencionado anteriormente, gráficos relacionais, são aqueles que representam duas ou mais variáveis, permitindo visualizar evidências sobre causa e efeito. A vicissitude das tramas de múltiplas variáveis é que, por possibilitarem a sobreposição de diversos tipos de dados, tornam muito fácil a "descoberta" de conexões que de fato não existem. 0 desafio da estatística é manter a distinção entre "correlação" - o surgimento de tendências semelhantes entre diferentes variáveis - e "causalidade" - o impacto direto de uma variável sobre a outra (ROAM, 2008, p.225). Thompson (2010) cita como exemplo o debate furioso sobre a vacinação infantil, que há anos vem alarmando os pais (principalmente norte-americanos) com base em "conclusões desastrosas de informações anedóticas". Ativistas propagam histórias de crianças que pareciam bem, mas que, após serem vacinadas, "desenvolveram autismo". Quando, no entanto, se examinam dados de milhões de crianças vacinadas, a conexão desaparece: correlação não é causalidade, e casos isolados pouco podem provar (THOMPSON, 2010).

Quanto aos gráficos de área, Tufte alerta para o que ele denominou de "Lie Factor" (fator de mentira), significando a medida em que uma forma não representa o valor, podendo fomentar

Figura 33. Infográfico $O$ Barulho em São Paulo.

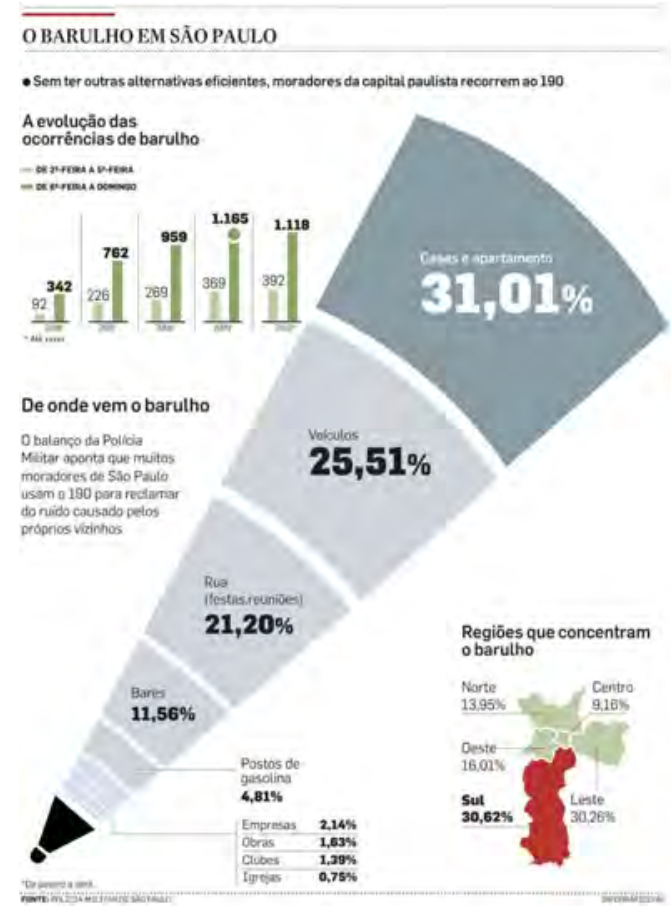

Figura 34. Sobreposição dos setores "Bares" e "Casas".

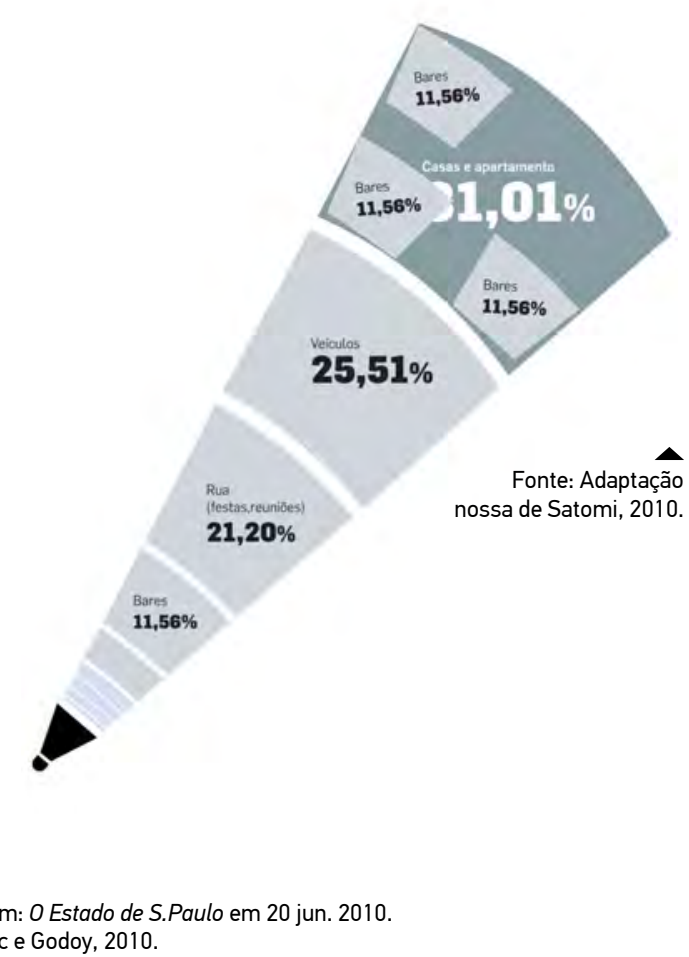


erros de interpretação. Dessa forma, “Fator de Mentira = tamanho do efeito mostrado em gráfico / tamanho do efeito em dados" (TUFTE, 2007, p.57, tradução nossa).

0 efeito pode ser verificado no gráfico central da Figura 33, que faz alusão a ondas sonoras para indicar os principais responsáveis por reclamações de barulho noturno na capital paulista. Entre as categorias "Bares" e "Rua" há uma diferença de 9,64\%, quase o dobro da diferença de 5,5\% existente entre "Veículos" e "Casas". Mas a imagem passa a impressão de que a disparidade entre as duas últimas categorias é muito maior que a diferença entre as duas primeiras. Para evidenciar a distorção gráfica, Satomi (2010) sobrepôs o setor equivalente a "Bares" (11,56\%) ao setor "Casas" $(31,01 \%)$. Se a representação gráfica estivesse correta, a área deveria ter sido totalmente coberta por três setores de "Bares” (Figura 34).

Tufte também rejeita o emprego indis-

Figura 35. Gráfico de pizza em três dimensões. criminado da perspectiva, por adicionar desnecessariamente uma dimensão a mais à figura e poder induzir a ambiguidade na percepção: "A quantidade de dimensões informativas (variáveis) representadas não deverá exceder o número de dimensões nos dados" (TUFTE, 2007, p.71, tradução nossa). Em exemplo publicado por Few (2007, p.9), percebemos que, ao adicionar uma terceira dimensão a um gráfico bidimensional, a interpretação fica completa-

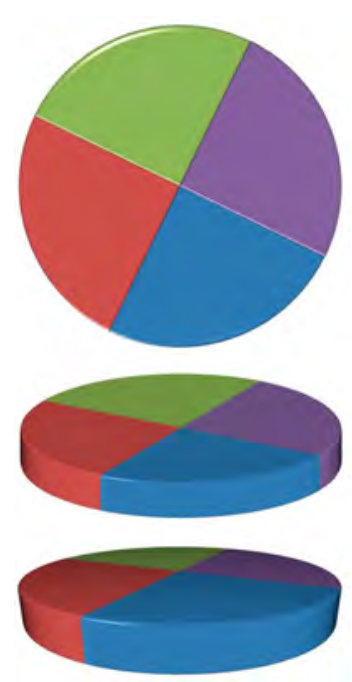

Fonte: Few, 2007, p.9. mente comprometida (Figura 35).

\subsubsection{2 - Clareza vs. chartjunk}

Diversos autores sustentam que, no Design da Informação, a clareza é prioritária em relação à ornamentação, e defendem a concisão na representação visual de dados (CAIRO, 2013, p.10; MAEDA, 2006, p.89; RENDGEN, 2012, p.97; ROAM, 2008, p.165; TUFTE, 2007, p.177). A clareza é, aliás, responsabilidade de todo designer: “Talvez seja esta a diferença fundamental entre a arte pura e o design puro. Enquanto a grande arte faz você se perguntar, o grande design torna as coisas claras" (MAEDA, 2006, p.70, tradução nossa). 
Tufte (2007, p.71-92) considera fundamental que se mostre os dados acima de tudo e rejeita o chartjunk (neologismo que poderia ser traduzido como "lixo de gráfico"), elementos desnecessários que servem apenas para poluir visualmente - como o grid aparente, perspectivas sem função, componentes meramente decorativos, sombras e texturas. Para o autor, os motivos para a proliferação de chartjunk seriam: a falta de conhecimento estatístico dos artistas gráficos, a crença de que dados estatísticos são entediantes e a crença de que gráficos são destinados apenas aos leitores menos sofisticados, aqueles que preferem "ler as figuras". Em sua visão, gráficos são ornamentados desnecessariamente apenas para mostrar "o óbvio" aos supostamente "ignorantes", o que torna difícil imaginar qualquer doutrina mais propensa a "reprimir o progresso intelectual em um campo" (TUFTE, 2007, p.53, tradução nossa).

Segundo Wurman (1991, p.123), o excesso de elementos cumprindo uma mesma função informativa reduz a "qualidade do inesperado" ou o "efeito de surpresa" da informação e, por consequência, a informação em si. A proposição é que se evite ao máximo essa dose extra de previsibilidade, a redundância .

Tufte (2007, p.92-93) emprega o termo data-ink para se referir ao essencial não apagável em um gráfico (a tinta não redundante), de forma que:

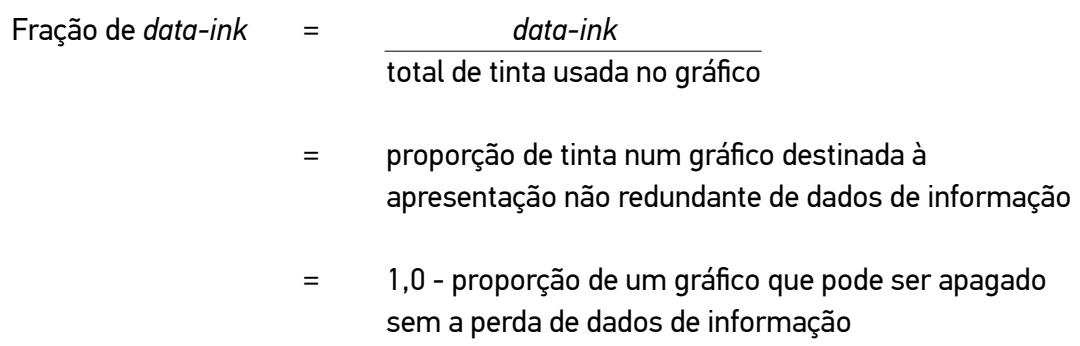

(TUFTE, 2007, p.93, tradução nossa)

Para o autor, a proporção de data-ink em relação ao total de tinta no gráfico deve ser sempre a maior possível. Num cenário ideal, empregam-se poucos elementos que, por sua vez, desempenham múltiplas funções.

Em contrapartida, a busca por clareza pode também requerer a inserção de legendas e textos explicativos, para evitar equívocos e facilitar a compreensão. Se bem planejadas, palavras em gráficos podem ser data-ink (TUFTE, 2007, p.180).

Massironi (2002, p.69) defende que o volume de informações apresentadas seja moderado, esquematizando visualmente a relação entre a "quantidade de informação" e a "quantidade de 
conhecimento compartilhado" entre emissor e receptor (Figura 36). Se por um lado, quanto mais conhecimento compartilhado, mais eficiente a comunicação; por outro, o volume de informações apresentadas deve ser equilibrado, evitando-se a insuficiência ou excesso de dados.

\section{Figura 36. Eficiência Comunicativa segundo Massironi.}

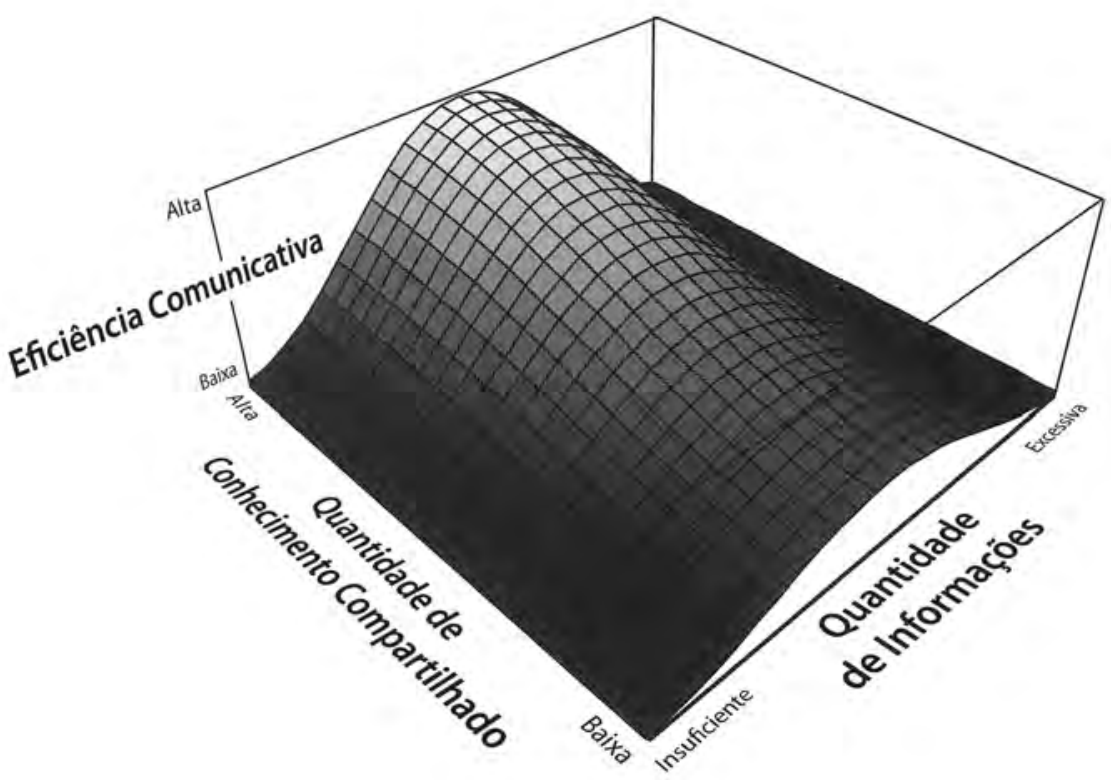

Fonte: Tradução e adaptação nossa a partir de Massironi, 2002, p.69.

Garralón (apud CAMPOS, 2016, p.92) aponta que a "competência de um leitor de texto científico" depende de seus "conhecimentos prévios" e também de seu "interesse" no tema tratado, o que nos conduz ao terceiro princípio infográfico - a satisfação.

\subsubsection{SATISFAÇÃO}

O design eficiente estabelece com o usuário uma interface atraente e convidativa, motivando a exploração do conteúdo: em toda comunicação há um "componente persuasivo" (FRASCARA, 2011 , p.14). Ciuccarelli (2012, p.80-82) enfatiza fatores como a beleza e o prazer na apresentação visual de dados, apontando que no âmbito acadêmico já se estabeleceu que a emoção é uma força cognitiva que contribui para o sense-making. 0 autor acredita que atualmente há mais espaço para 
se debater uma "possível função" para o non-data ink, contestando a noção de embelezamento como puramente ornamental e desnecessário, ou até mesmo prejudicial. 0 próprio Tufte (2007, p.137) reconhece que, na totalidade do projeto, devem ser consideradas não apenas a eficiência, como também a complexidade, estrutura, densidade e beleza.

O prazer estético pode ser definido como "a realização de uma atividade esperada" (LIPPS apud FRASCARA, 2011, p.27) e a beleza como "o resultado de clareza e sistemática" (VELDE apud MIJKSENAAR, 1997, p.18). É poder prever o que irá suceder, e deleitar-se com a comprovação da hipótese. E somente é possível prever se a estrutura for assimilada. Na música, por exemplo, ritmo, melodia e chave tonal determinam as expectativas dos ouvintes. Se a música se desenvolve conforme marcos previsíveis - com a necessária quota de novidade (informação) - o público experimenta o prazer (Frascara, 2011, p.27). Dessa forma, muitas questões racionais desempenham um papel na percepção da beleza, tornando o design uma atividade que, ao unir a confiabilidade e a utilidade, "intensifica a percepção da beleza" (MIJKSENAAR, 1997, p.17).

\subsubsection{1 - Atratividade}

Aprender significa lembrar aquilo que nos interessou (WURMAN, 2012, p.40); e para lograr o interesse do espectador, um gráfico deve ser "amigável", atraindo e provocando curiosidade (TUFTE, 2007, p.183). Se o que mostramos "ressoa com nosso público" - seja porque mostra exatamente o que eles esperavam ou porque os surpreende -, eles irão se interessar (ROAM, 2008, p.165).

0 conceito é aplicado extensivamente em Lá fora:

Figura 37. Página do livro de Divulgação Cientifica Lá fora... (DIAS; ROSÁRIO, 2014).

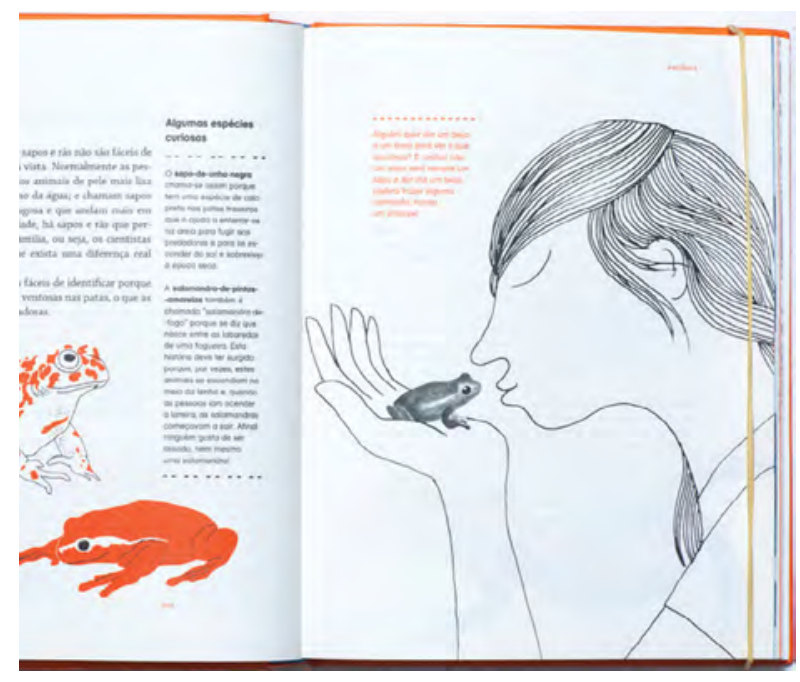

Fonte: CAMPOS, 2016, p.139.
Guia para descobrir a natureza (DIAS; ROSÁRIO, 2014), livro de Divulgação Científica destinado ao público infantil. Em um capítulo que explora os anfíbios, por exemplo, uma página inteira é ocupada pela ilustração de uma menina beijando um sapo (Figura 37). Na visão de Campos (2016, p.139), a imagem é atraente porque é maior e "mais sedutora" - por remeter aos "contos de fadas, às histórias de princesas que beijam sapos, e por provavelmente estar presente no imaginário da maioria das crianças e adultos do mundo ocidental". Mas o conteúdo informativo associado à imagem é muito menos fantasioso, detalhando de forma objetiva as características de diferentes espécies de rãs e sapos: 


\begin{abstract}
“Essa relação entre opostos - os pensamentos da fábula e da ciência - enriquece o discur-so do livro informativo ao utilizar outras vias de pensamento que não a racional para explicar temas relevantes. Assim, o livro acolhe visões outras que não a da ciência e expressa como elas estão em jogo fora daquele universo de divulgação [...]."

(CAMPOS, 2016, p.139-140)
\end{abstract}

Em se tratando especificamente da representação de dados quantitativos, Tufte (2007, p.177) defende que modelos "atraentes" seguem alguns preceitos: têm formato e design apropriados; empregam palavras, números e desenhos em conjunto; refletem equilíbrio; apresentam uma complexidade acessível de detalhes; frequentemente têm uma qualidade narrativa; são desenhados de forma profissional, com produção técnica cuidadosa; e evitam ornamentação sem conteúdo.

A diagramação da página, como um todo, também representa componente de atratividade, posto que o leitor não enxerga as informações isoladamente. Numa composição agradável, gráficos possuem formatos variados, integrando-se harmoniosamente com o texto. Um exemplo é o infográfico central da Figura Figura 38. Página de jornal contento o infográfico Difícil viagem ao centro...

38, um dos vencedores do Malofiej Awards em 2010, que emprega barras verticais em perspectiva isométrica para indicar as diferentes camadas de exploração de petróleo. Apesar de o recurso da perspectiva não ser estritamente necessário para a representação dos dados, seu emprego gera contraste com os demais elementos gráficos bidimensionais, valorizando o conjunto (KANNO, 2013, p.125).

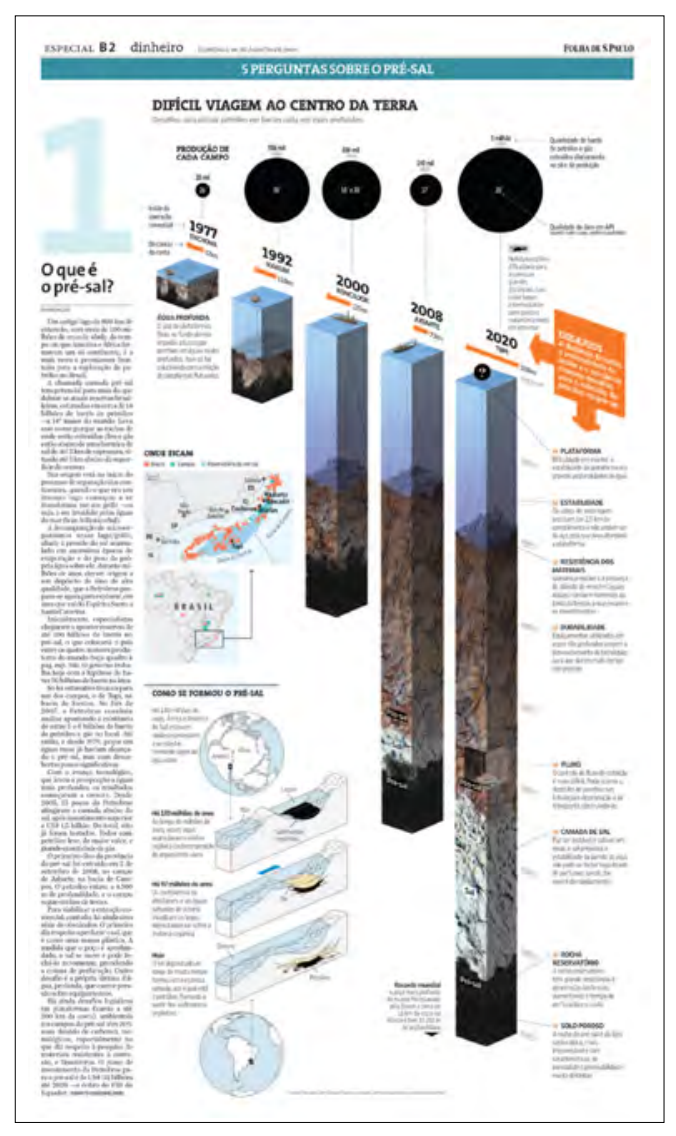

Infográfico de: Marcelo Pliger. Publicado em: Folha de S.Paulo, 2009 Fonte: Kanno, 2013, p.125. 


\subsubsection{2 - Beleza na simplicidade}

“Claro que a ideia abstrata deve ser ocasionalmente explicada - parafraseada, por assim dizer - com o auxílio de imagens; mas discretamente, cum grano Salis ${ }^{28 "}$ (SCHOPENHAUER apud KONG, 2006:207). Um dos aspectos da atratividade visual é a ponderação na quantidade de elementos visuais: a elegância gráfica é frequentemente encontrada na simplicidade do design e na complexidade dos dados (TUFTE, 2007, p.177).

Ao longo do último século, percebe-se uma crescente influência do princípio da simplicidade nos meios de comunicação em geral. No âmbito do jornalismo brasileiro, os textos começaram a ganhar a forma atual em meados do séc. XX, quando "a linguagem pomposa dos literatos" foi substituída pela "busca por objetividade" (SILVEIRA, 2010, p.39). 0 Manual de Redação e Estilo de O Estado de S. Paulo de 1997, por exemplo, defende a concisão como condição essencial do texto jornalístico: "0 espaço hoje é precioso; o tempo do leitor, também" (MARTINS, 1997, p.15).

A relevância comercial da simplicidade tem também se tornado evidente. Em The Laws of Simplicity (2006), Maeda, designer e então professor do MIT, analisa o valor de mercado da simplicidade quando aplicada à comunicação corporativa, à tecnologia e ao design. 0 sucesso dos produtos da Apple (que, segundo o autor, custam mais para fazer menos) e as interfaces limpas do Google evidenciam o desejo e a necessidade do público pela simplificação. Seguindo o mesmo princípio, os TED Talks, palestras sucintas proferidas por especialistas em áreas diversas - de medicina a estatística -, tornaram-se um sucesso mundial.

Em território nacional, o USP Talks ${ }^{29}$, organizado pela Pró-Reitoria de Pesquisa da Universidade de São Paulo, convida professores renomados da academia para discursarem, de forma breve e objetiva, sobre temas de interesse para a sociedade.

$\mathrm{Na}$ Divulgação Científica por mídias impressas, a simplicidade bem planejada prova-se atraente. Por sua complexidade, textos científicos repelem naturalmente a atenção do público não especializado, tornando decisiva a intervenção de um profissional da comunicação visual (CIUCCARELLI, 2012, p.82).

A Figura 39 reproduz o infográfico Two Mindsets, elaborado por Holmes para uma revista de Divulgação Científica da Universidade de Stanford. A reportagem apresenta os resultados de um estudo em psicologia conduzido pela Dra. Carol Dweck, durante o qual foram identificadas duas formas distintas de se pensar sobre as habilidades humanas: enquanto algumas pessoas acreditam

\footnotetext{
${ }^{28}$ Do latim: com um grão de sal.

29 Disponível em: <http://www.prp.usp.br/eventos/usptalks>. Acesso em: 06 jul. 2017.
} 
que a inteligência e habilidades podem ser aprendidas, outras acreditam que o sucesso decorre principalmente de habilidades inatas. Como consequência, cada um dos dois tipos de mentalidade inspira uma cadeia de pensamentos e comportamentos diferente (DWECK in KRAKOVSKY, 2007, p.2). 0 infográfico de Holmes demonstra como uma teoria complexa pode, ao invés de intimidar o leitor, ser representada de forma a atraí-lo pela simplicidade visual.

Figura 39. Infográfico Two Mindsets.

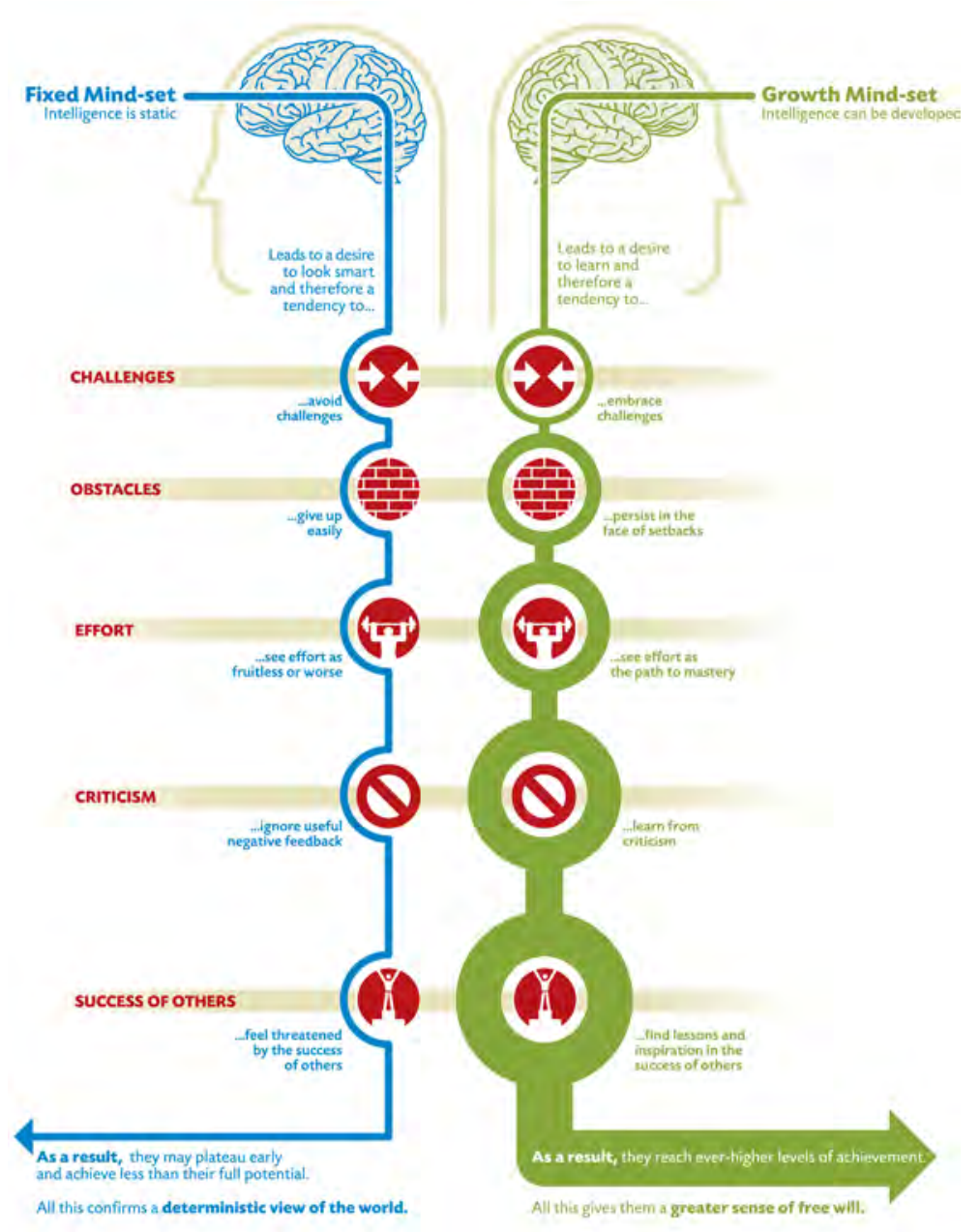

Infográfico de Nigel Holmes publicado na revista de Divulgação Científica Stanford Magazine, 2007. Fonte: Krakovsky, 2007.

Por fim, tanto o Design da Informação quanto os projetos de divulgação da ciência objetivam contribuir para o processo comunicacional através da transmissão clara e precisa do conteúdo informativo, associada a um tratamento estético atraente. Como frisado anteriormente, o objeto da análise que apresentaremos a seguir encontra-se nesta intersecção entre os propósitos da Divulgação Científica e a disciplina do Design da Informação. 
Capítulo 4

PROPOSTA DE ANÁLISE 


\section{Capítulo 4 PROPOSTA DE ANÁLISE}

Figura 40. Modelo de Mijksenaar aplicado a um mapa Michelin

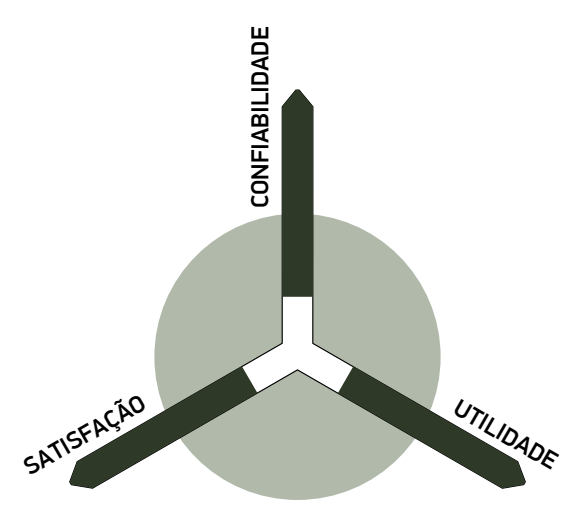

Fonte: MIJKSENAAR, 1997.

Frascara (2011, p.14) defende que os objetivos de um produto de Design da Informação devam ser tanto atingíveis quanto mensuráveis. Pouco proveito há na proposição de metas vagas ou imprecisas, dificultando o estabelecimento de diretrizes para o processo de criação e prejudicando a avaliação do produto final. Sob ótica similar, Mijksenaar (1997, p.18) determina uma "fórmula prática" de mensuração, alicerçada nas três funções que caracterizariam um bom projeto de design: utilidade, confiabilidade e satisfação (conforme discutidas no Capítulo 3). Seu modelo é composto por "termômetros" que registram o valor de cada uma das funções em determinado produto. 0 diagrama apresentado na Figura 40, por exemplo, refere-se ao diagnóstico de um mapa Michelin, e indica que há um equilíbrio entre os três princípios. 0 círculo central indica um 
nível médio, abaixo do qual "nenhum bom produto deve cair, embora possa, é claro, sempre fazer melhor" (MIJKSENAAR, 1997:18, tradução nossa).

Já as Figuras 41 e 42 reproduzem gráficos que analisam as placas de sinalização de uma estrada holandesa e de uma estrada inglesa, respectivamente. No primeiro caso, as informações são apresentadas de forma bastante útil, mas o avaliador o classificou como menos satisfatório esteticamente. A segunda placa, por outro lado, parece trazer satisfação visual, apesar de apresentar menor nível de utilidade. Dessa forma, o esquema possibilita prever a combinação de qualidades necessárias em determinado projeto de design, além de analisar produtos já existentes (MIJKSENAAR, 1997:18).
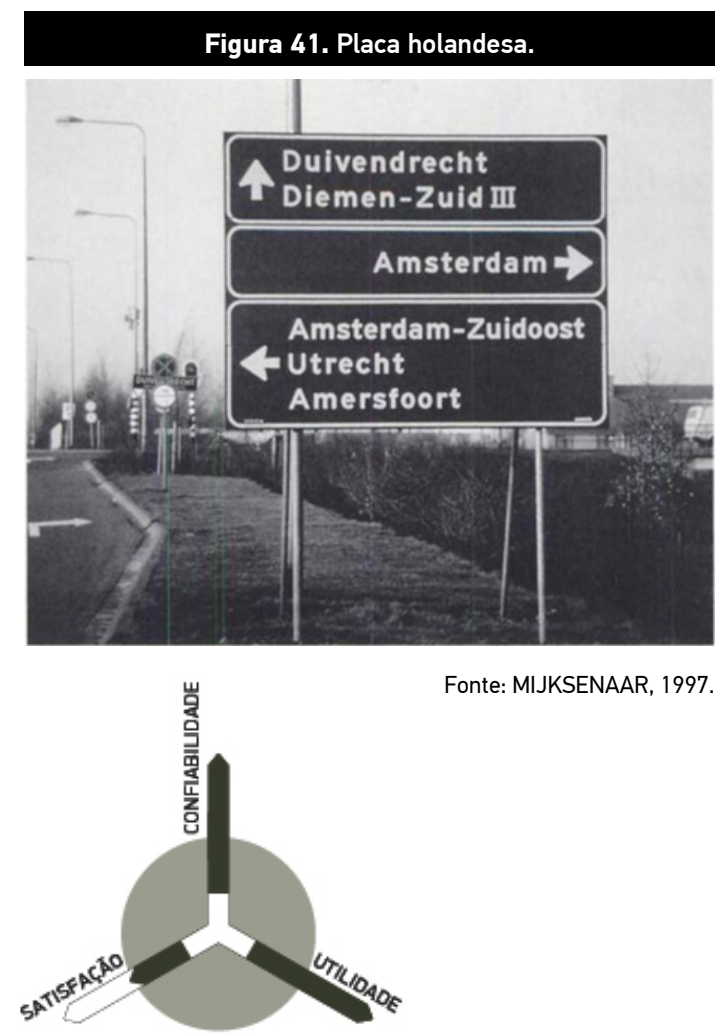

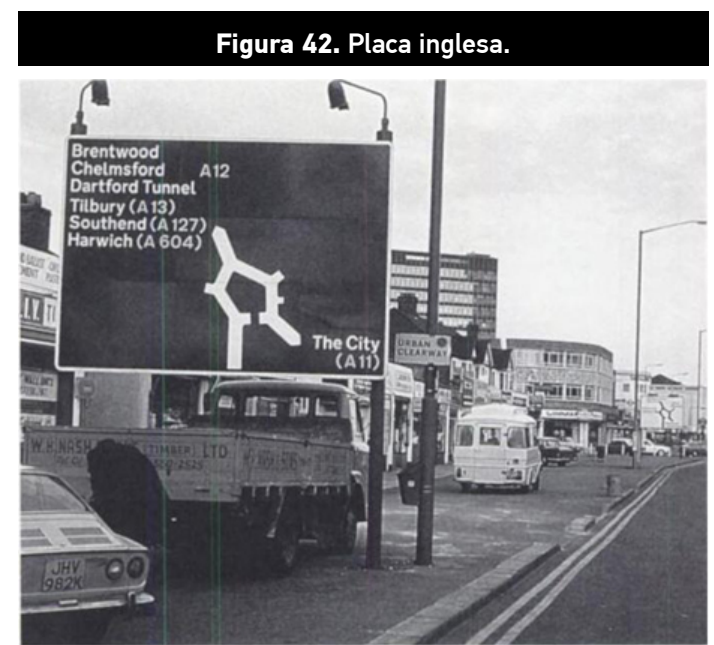

Fonte: MIJKSENAAR, 1997.

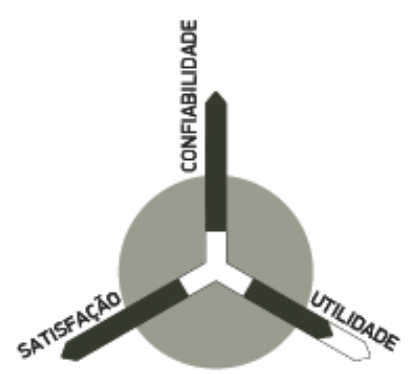

O modelo proposto na presente pesquisa toma como ponto de partida o paradigma de Mijksenaar. Entendendo que, em um infográfico, os elementos podem desempenhar múltiplas funções, levando ao máximo aproveitamento de cada componente (TUFTE, 2007, p.139), executamos uma desconstrução dos exemplares analisados e quantificamos os valores referentes a cada princípio. Apresentamos a seguir o roteiro seguido para a realização das análises, iniciando pela seleção da amostragem. 


\section{1 \\ AMOSTRAGEM}

Desde a primeira edição (ago/1995) até a edição n 46 (set/1999), a publicação em estudo manteve o formato de boletim informativo, sob o título Notícias FAPESP (como relatado no Capítulo 1). Analisando visualmente o conjunto de edições, é possível constatar que, a partir da mudança do formato para o de revista, e do nome para Pesquisa FAPESP, em outubro de 1999 (edição n 47), houve três projetos gráficos bastante distintos.

0 primeiro projeto foi mantido até a edição n 65 (jun/2001), conforme visualizado no Quadro 4. Da edição no 66 (jul/2001) até a edição no 188 (out/2011), foi adotado o segundo projeto gráfico, no qual percebe-se um uso mais frequente de áreas brancas e de respiro, além de maior liberdade na distribuição de elementos entre as colunas.

Em vigor desde a edição no 189 (nov/2011), o projeto gráfico atual demonstra um grid mais flexível, resultando em composições diversificadas ao longo da revista. Nas edições que adotam este projeto gráfico, também identificam-se mudanças no emprego de famílias tipográficas (conforme o Quadro 5). 0 projeto anterior empregava a fonte Minion em grandes blocos de texto, ao passo que a fonte Interstate surgia em títulos e outros textos de destaque. No projeto atual, a fonte da massa de texto é a Mercury, enquanto a fonte dos títulos é uma tipografia customizada ${ }^{30}$ que foi sendo adaptada: durante sete edições ( $n^{\circ} 189$ a n 195), a fonte Fapesp, ainda em fase de construção, foi empregada com o intuito de ser testada. Após uma série de atualizações, a fonte Fapesp foi finalizada e denominada Oculum, passando a vigorar na revista a partir da edição no 196 (jun/2012).

0 projeto gráfico atual também passou por adaptações, havendo modificações em alguns detalhes da diagramação. Podem ser identificadas três fases principais, conforme apresentado no Quadro 6. A primeira fase engloba desde a edição no 189 (nov/2011) até a edição n 196 (jun/2012).

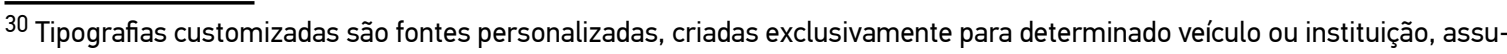
mindo o papel de transportar seus valores e personalidade (CARDINALI, 2015, p.21).
} 
Quadro 4. Mudanças significativas de layout.
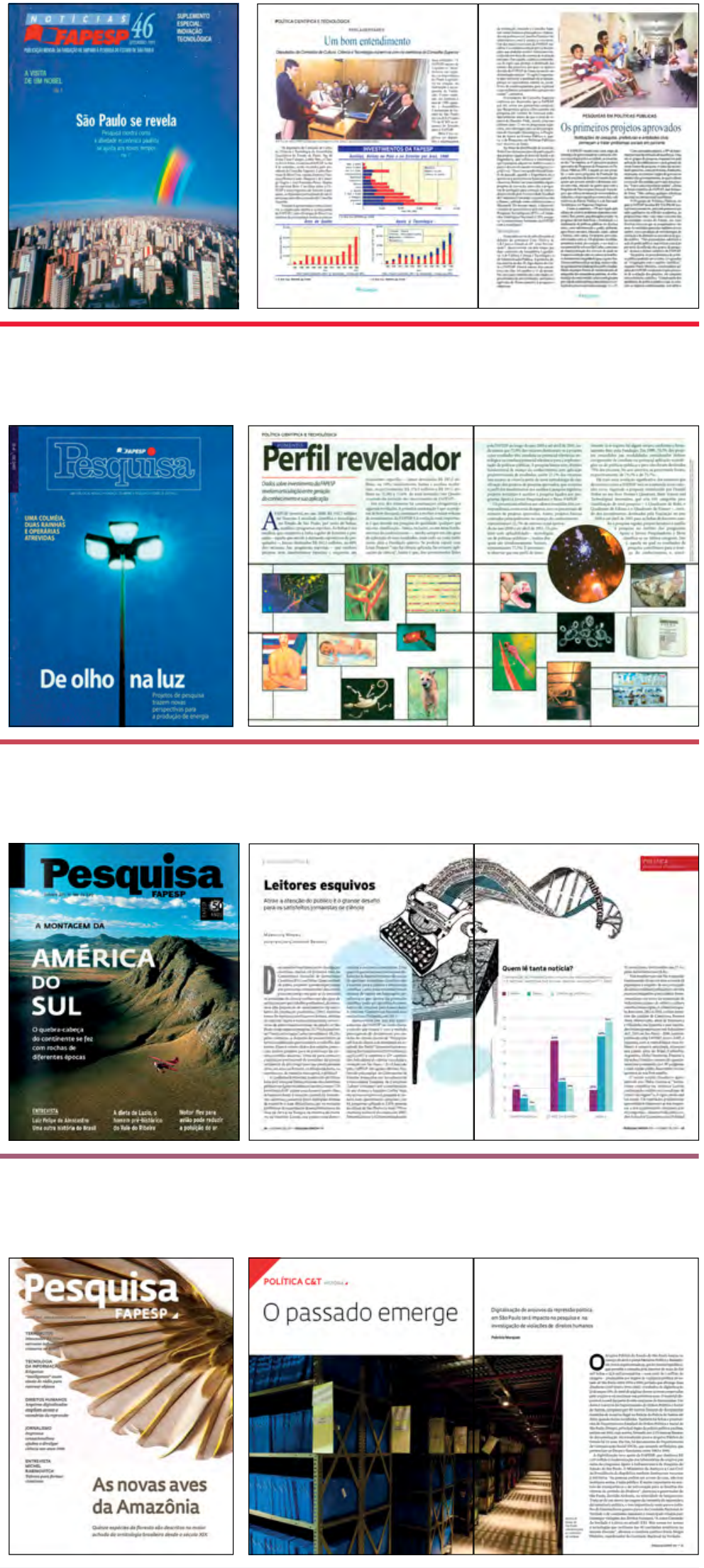

Fonte: Elaboração nossa. 


\section{CULTURA CIENTÍFICA}

Títulos: Interstate

Massa de texto: Minion

edição 66 (jul/2001) - edição 188 (out/ 2011) ois estudos brasileiros sobre divulgação científica, citados em primeira mão na Conferência Mundial de Jornalismo Científico 2011, em Doha, Qatar, no final de junho, propōem quando superpostos um panorama curiosamente desconexo para esse campo no país: se de um lado os jornalistas de ciência revelam um alto grau de satisfaçâo com seu trabalho profissional, de outro, uma alta proporção de uma amostra represen-
Títulos: Fapesp

Massa de texto: Mercury

edição 189 (nov/2011) - edição 195 (mai/2012)

\section{POLÍTICA C\&T}

A

reconstrução da Estação Comandante Ferraz, a base de pesquisa brasileira na Antártida destruída pelo fogo na madrugada do dia 25 de fevereiro, deverá ter início apenas daqui a dois anos, para ser concluida por volta de 2016. Mas a tragédia, que matou dois militares e foi deflagrada por um incêndio em geradores de energia, teve pelo menos um efeito imediato: reacendeu o debate sobre as ambições da ciência
Títulos: Oculum

Massa de texto: Mercury

edição 196 (jun/2012) - atual que permite a consulta pela internet de mais de 314 mil fichas e 12,8 mil prontuários - num total de 1 milhão de imagens - produzidos por órgãos de vigilância politica do estado de São Paulo entre 1924 e 1999, período que abrange duas ditaduras (1937-1945 e 1964-1985). O trabalho de digitalização já alcançou $10 \%$ do total de páginas desses acervos preservados pelo arquivo e vai continuar nos próximos anos. O material disponivel na web faz parte de três conjuntos de documentos. Um deles é o acervo do Departamento de Ordem Politica e Social 
Quadro 6. Ajustes finos no projeto atual.

\section{POLÍTICA C\&T _ HOMENAGEM}

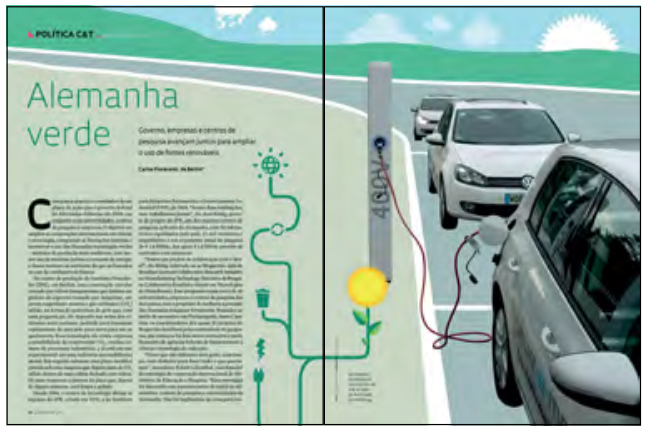

\section{POLÍTICA CET DIFUSÃO}

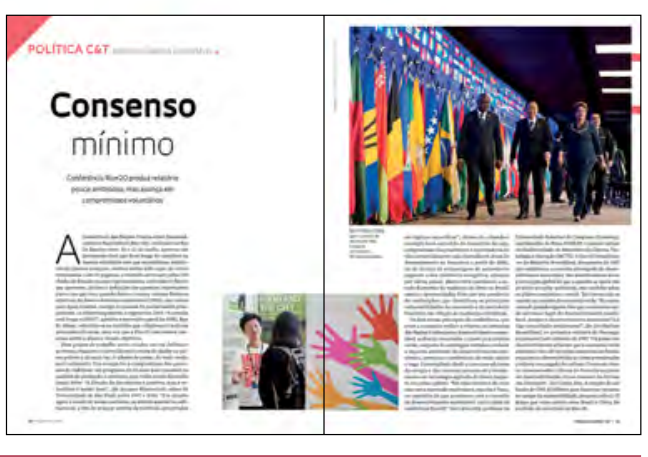

\section{POLÍTICA C\&T RANKING $\triangle$}

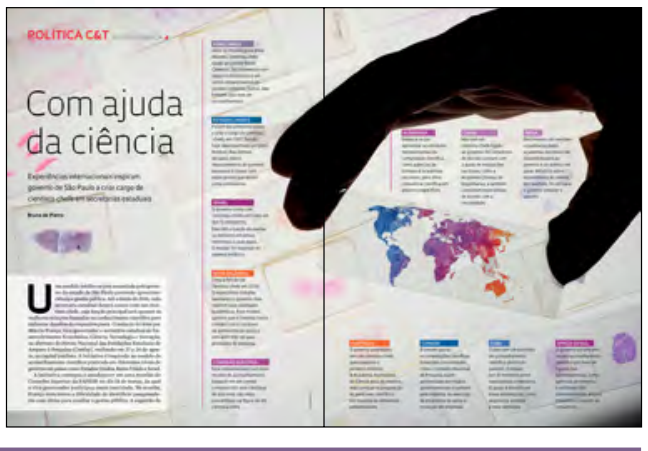

Fonte: Elaboração nossa. 
Na segunda fase, vigente nas edições no 191 (jul/2012) até n² 233 (jul/2015), percebem-se marcadores gráficos de auxílio em quantidades e dimensões maiores - como os triângulos coloridos no canto superior das páginas de abertura de cada editoria. Já a terceira fase, iniciada na edição n 234 (ago/2015), emprega marcadores de tamanho reduzido e uma diagramação mais padronizada.

Como recorte para o nosso corpus, decidimos, por uma questão de unidade gráfica, estudar edições pertencentes ao projeto gráfico atual, especificamente desta última fase de ajustes finos. 0 período de análise, portanto, tem início na edição n 234 (ago/2015) e finaliza na edição n 253, de março de 2017 (mês limite para que encerrássemos a coleta de dados a tempo de finalizar as análises para a entrega da presente dissertação). 0 período abrange vintes meses (e consequentemente vinte edições), quantia suficiente para a uma verificação gráfica consistente do objeto em estudo.

\subsubsection{RECURSOS GRÁFICOS}

Num primeiro momento, analisamos a revista como um todo, observando desde a capa até a contracapa: elementos verbais e visuais, pertencentes tanto às editorias principais quanto às seções menores. Examinando a composição das páginas, identificamos quatro categorias de recursos gráficos utilizados: infográficos, fotografias, ilustrações e tabelas. 0 passo seguinte consistiu em computar a quantidade de recursos gráficos presentes em cada matéria ou seção, conforme definidos a seguir:

a) Infográficos: Unidades que conjugam imagens, palavras, números e/ou outros símbolos de forma planejada, visando facilitar a assimilação da reportagem (em sua totalidade ou não) e enriquecer a experiência do receptor com o conteúdo informativo, numa relação em que tanto elementos visuais quanto verbais possuem valor de informação, atuando em sincretismo (conforme discutido no Capítulo 2). 
b) Fotografias: Imagens produzidas de forma automática (MACHADO, 2002, p.227), originadas por fixação em uma superfície sensível à luz (independentemente se um filme fotográfico ou meio eletrônico). Quando uma fotografia estiver associada a sinais gráficos, palavras e/ou números, de forma a gerar valor informativo, consideramos que o conjunto representa um infográfico e não o computamos como uma fotografia.

c) Ilustrações: Para efeitos de nossa pesquisa, computamos nesta categoria recursos imagéticos que não sejam fotografias e que não associem a linguagem pictórica à verbal ou numérica de forma a constituir um conjunto informativo. Em geral, são imagens de interpretação mais autônoma, que permitem leituras subjetivas e sem significativa interferência na assimilação da reportagem. Neste conceito, incluem-se aquilo que Campos (2016, p.149-151) denominou “ilustrações evocativas": aquelas "sem referência direta no texto verbal principal" e cuja função primordial "não é apresentar dados ou dar a ver informações precisas do texto, senão proporcionar intervalos de respiro ao longo da leitura".

d) Tabelas: Computamos, neste grupo, conjuntos alfanuméricos cuja estrutura consiste em sequenciamentos horizontais e verticais (LIMA, 2009, p.101) e que não incluam imagens ou símbolos que não representem palavras ou números.

Para exemplificar o método de contagem de recursos gráficos, apresentamos os exemplos das reportagens Terrenos férteis para a inovação e $A$ química do futuro, ambas da edição n 246 (ago/2016). Na primeira reportagem, verificamos a presença de duas fotografias, duas ilustrações, um infográfico e nenhuma tabela (conforme indicado no Quadro 7). Já na segunda matéria, há um predomínio fotográfico, somando-se quatro fotos, uma tabela e nenhum infográfico ou ilustração. 
Quadro 7. Exemplos de contagem de recursos gráficos.

ed.246 | p.30-33
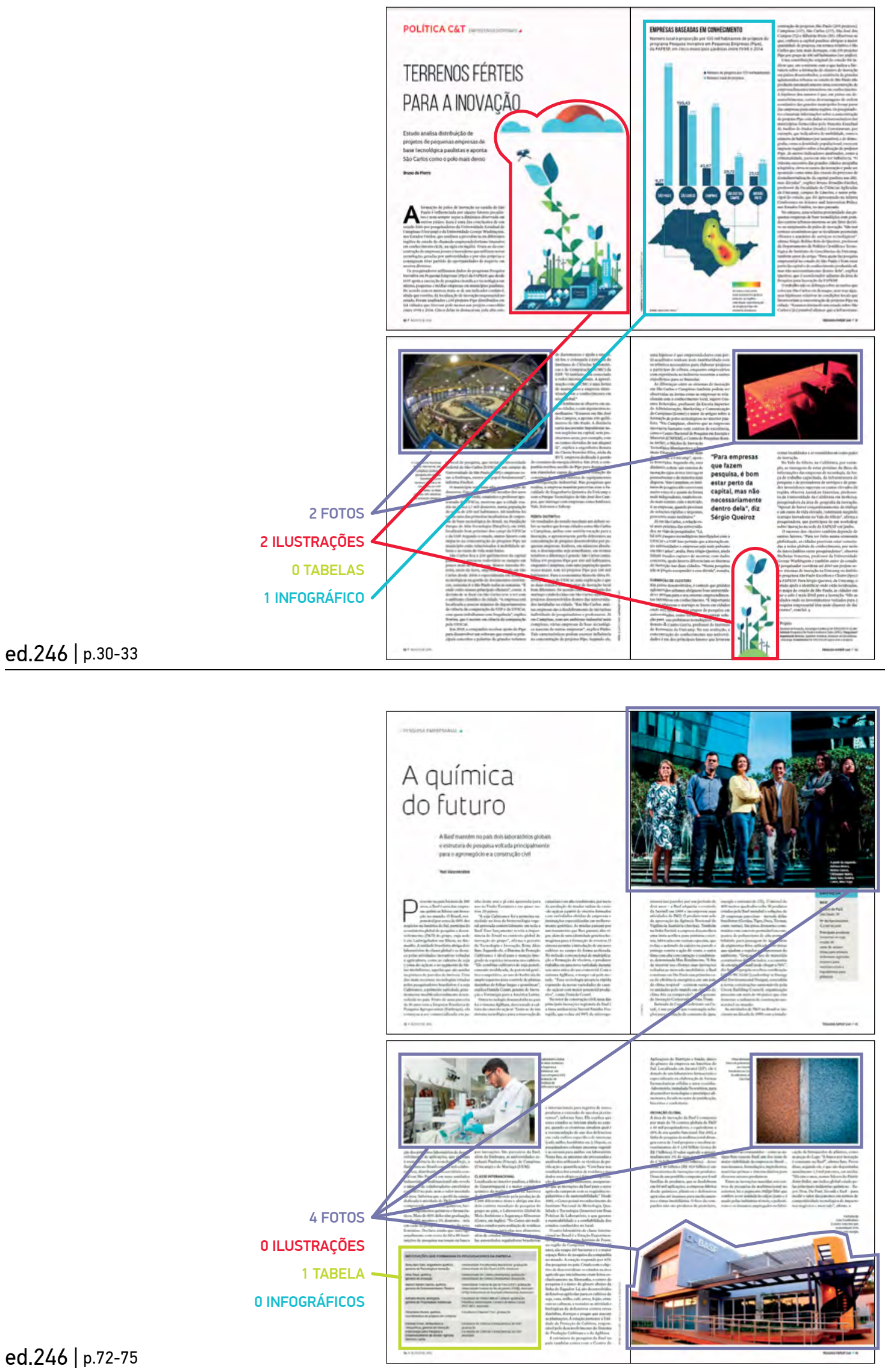

Fonte: Elaboração nossa a partir de imagens da revista. 
Nesta etapa de levantamento de recursos gráficos, examinamos as seguintes seções e editorias:

\begin{tabular}{|c|c|c|}
\hline - Boas práticas & - Capa (matéria de capa) & - Obituário \\
\hline - Dados ${ }^{31}$ & - Entrevista & - Memória \\
\hline - Notas ${ }^{32}$ & - Política C\&T & - Arte \\
\hline - Estratégias ${ }^{33}$ & - Ciência & - Resenhas \\
\hline - Tecnociência ${ }^{34}$ & - Tecnologia & - Carreiras \\
\hline - Dados e projetos & - Humanidades & \\
\hline
\end{tabular}

Não computamos os recursos gráficos de algumas seções cujos dados não seriam profícuos para a nossa análise, por não preverem o uso de infográficos (como Editorial ou Cartas), ou por serem compostas por imagens que não são produzidas pela revista (como anúncios e Classificados). As imagens do Índice também não foram levantadas por se repetirem nas respectivas matérias e seções. As seções cujos dados não foram computados são as seguintes:

- Índice

- Classificados

- Cartas (Comentários)

- Anúncios

- Carta da editora

- Online

- Fotolab

No total, computamos os dados de 519 matérias e seções. Dentro deste conjunto, verificamos a presença de 2.132 recursos gráficos, dos quais: 1.569 fotografias, 273 ilustrações, 259 infográficos e 31 tabelas (conforme Quadro 8). (A planilha com os dados completos pode ser visualizada no Apêndice A ou pelo endereço eletrônico <http://goo.gl/3Vitv1>.)

\footnotetext{
${ }^{31}$ Até outubro de 2016, esta seção era intitulada Dados e projetos.

32 Esta seção surge a partir de janeiro de 2017.

33 Esta seção aparece apenas até dezembro de 2016.

${ }^{34}$ Esta seção aparece apenas até dezembro de 2016.
} 


\section{Quadro 8. Quantidade de recursos gráficos por edição.}

FOTOS

\begin{tabular}{|c|c|c|c|c|c|}
\hline 2015 | agosto & ed.234 & 84 & 10 & 1 & 23 \\
\hline 2015 | setembro & ed.235 & 65 & 20 & 3 & 11 \\
\hline 2015 | outubro & ed.236 & 73 & 7 & 2 & 11 \\
\hline 2015 | novembro & ed.237 & 85 & 12 & 0 & 9 \\
\hline 2015 | dezembro & ed.238 & 72 & 23 & 1 & 16 \\
\hline 2016 | janeiro & ed.239 & 89 & 18 & 3 & 12 \\
\hline 2016 | fevereiro & ed.240 & 60 & 17 & 0 & 12 \\
\hline 2016 | março & ed.241 & 68 & 13 & 2 & 17 \\
\hline 2016 | abril & ed.242 & 80 & 20 & 0 & 7 \\
\hline 2016 | maio & ed.243 & 76 & 11 & 2 & 7 \\
\hline 2016 | junho & ed.244 & 80 & 9 & 2 & 9 \\
\hline 2016 | julho & ed.245 & 101 & 9 & 1 & 7 \\
\hline 2016 | agosto & ed.246 & 81 & 8 & 4 & 14 \\
\hline 2016 | setembro & ed.247 & 84 & 10 & 1 & 11 \\
\hline 2016 | outubro & ed.248 & 86 & 10 & 2 & 9 \\
\hline 2016 | novembro & ed.249 & 80 & 8 & 2 & 19 \\
\hline 2016 | dezembro & ed.250 & 74 & 15 & 1 & 15 \\
\hline 2017 | janeiro & ed.251 & 91 & 21 & 0 & 13 \\
\hline 2017 | fevereiro & ed.252 & 69 & 17 & 3 & 15 \\
\hline \multirow[t]{2}{*}{2017 | março } & ed.253 & 71 & 15 & 1 & 22 \\
\hline & TOTAL & .569 & 273 & 31 & 259 \\
\hline
\end{tabular}


Figura 43. Em cada edição da revista houve, em média:

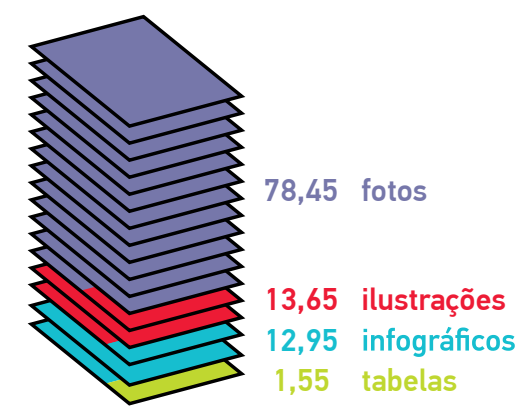

Edição com mais infográficos: 234 (ago/2015) - 23 infográficos

Edições com menos infográficos: 242 (abr/2016) - 7 infográficos

243 (mai/2016) - 7 infográficos

245 (jul/2016) - 7 infográficos

Editoria com mais infográficos:

Ciência - 82 infográficos

Editorias sem infográficos

Boas práticas

Obituário

Resenhas

Não foram encontradas reportagens sem recursos visuais

Fonte: Elaboração nossa.

Dentro do período analisado, portanto, $73,59 \%$ dos recursos gráficos são fotografias, 12,81\% são ilustrações, $12,15 \%$ são infográficos e 1,45\% são tabelas. Isto significa que, em média, cada edição da revista possui 78,45 fotos, 13,65 ilustrações, 12,95 infográficos e 1,55 tabelas (ver Figura 43).

A grande predominância de fotografias em relação aos outros três formatos parece refletir a valorização da imagem fotográfica como evidência e documentação para a ciência. A partir do seu surgimento, a fotografia passou a ser gradualmente adotada pela comunidade científica como uma ferramenta confiável para registrar e observar os mais diversos fenômenos naturais. Devido à sua propriedade automática, o artifício passou a ser percebido como eficiente e objetivo, menos suscetível aos erros ou subjetividades humanos (MACHADO, 2002, p.227). 
Mas a importância da fotografia para a ciência não se restringe ao seu caráter de neutralidade. A imagem fotográfica também permite observar, em análise posterior, fenômenos que estão além da capacidade de resolução da visão humana. Dentre os primeiros casos registrados, alguns frequentemente citados são: a pioneira fotografia de alta velocidade de Eadweard Muybridge (ca. 1877), que solucionou um debate em curso questionando se um cavalo galopante tirava todos os quatro cascos do chão simultaneamente (revelando resposta afirmativa); as fotografias em raios X de Wilhelm Röntgen (ca. 1895); e o registro fotográfico da Nebulosa do Anel de Lyra por Paul e Prosper Henry (ca. 1885) (WILDER apud NATHAN, 2011, p.1-2).

Outra função da fotografia é a de "ilustrar a ciência", fornecendo um meio eficiente para a promulgação do pensamento e descobertas científicas tanto para o público mais amplo quanto na própria esfera da Comunicação Científica (WILDER apud NATHAN, 2011, p.2).

Mesmo no âmbito do jornalismo tradicional, nas coberturas "quentes" (aquelas que abordam notícias inéditas, recentes ou ainda em andamento), a fotografia é considerada "mais importante", enquanto registro da notícia, do que, por exemplo, um infográfico (KANNO, 2013, p.146).

Vale também ressaltar a função das imagens fotográficas na valorização estética de uma publicação. Função esta que, no caso da Pesquisa FAPESP, é expressa de forma mais evidente na inclusão da seção Fotolab, a partir da edição no $98(a b r / 2004)^{35}$. Esta seção, que geralmente ocupa a primeira página da revista, exibe fotografias enviadas por leitores e aparentemente selecionadas por critérios visuais. Desde a edição n 247 (set/2016), a chamada na revista diz o seguinte: "Sua pesquisa rende imagens bonitas? Mande para imagempesquisa@fapesp.br. Seu trabalho poderá ser publicado na revista". Ao eleger e pôr em evidência fotografias por sua capacidade de atração visual, a revista dá indícios de um movimento em direção à estética promovida pela mídia, e de um distanciamento gráfico da Comunicação Científica realizada entre pares.

Por outro lado, a incidência de tabelas no corpus, significativamente menor que a dos demais recursos gráficos, reflete a recomendação de Tufte (2007, p.56) para que se opte por este formato quando o conjunto de dados contiver vinte unidades de dados ou menos.

Quanto aos infográficos, a recorrência parece corresponder, na generalidade, às pautas nas quais "o didatismo é o foco da reportagem" (KANNO, 2013, p.146) ou naquelas que compreendem grandes quantidades de dados. Dentro do período analisado, a edição com mais infográficos

\footnotetext{
${ }^{35}$ A seção passou a chamar-se Fotolab apenas na edição no 189 (nov/2011). Da edição n 98 (abr/2004) até no 188 (out/2011), a seção era intitulada Imagem do mês.
} 
foi a nº 234 (ago/2015), englobando 23 infográficos. Nesta edição, por exemplo, há duas matérias com grandes quantidades de dados numéricos (Apoio demonstrado e Interação produtiva), e cinco reportagens cujo conteúdo requer a ilustração detalhada de processos ou produtos (Armadilha para fantasmas, A disputada conquista das Américas, Desafio compartilhado, Combate ao desperdício e Porco magro).

Fazendo um comparativo histórico, é possível verificar que não há variação significativa nas quantidades de recursos gráficos ao longo do período observado (Figura 44) ${ }^{36}$. As proporções também mantêm-se relativamente estáveis: as fotografias despontam como os elementos mais numerosos por edição, os infográficos e ilustrações alternam-se entre o segundo e terceiro mais recorrentes, enquanto as tabelas incidem em número muito mais discreto.

\section{Figura 44. Quantidade de recursos gráficos} no período analisado.

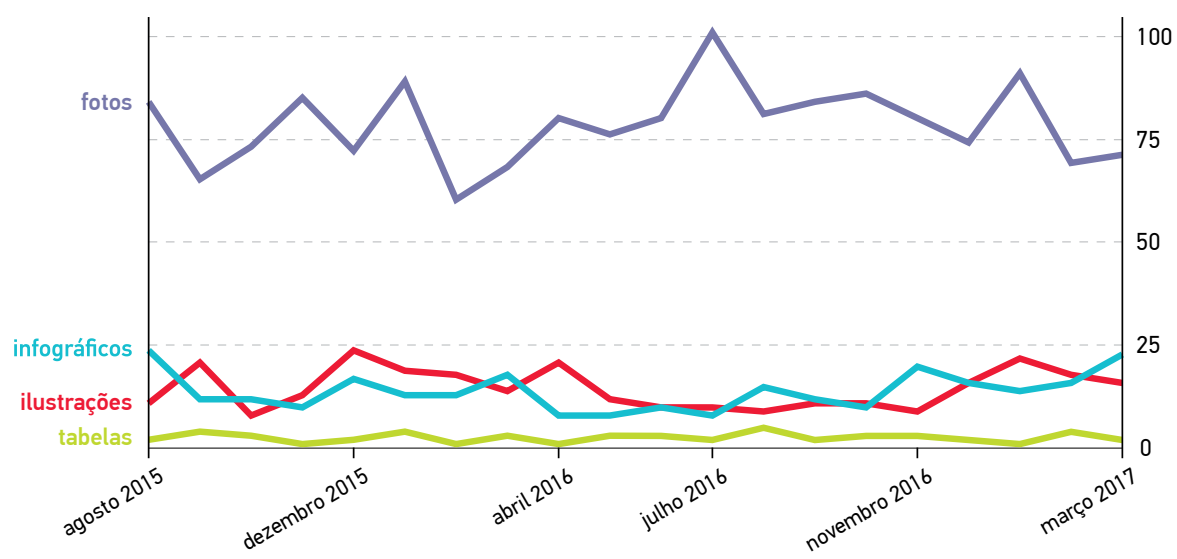

Fonte: Elaboração nossa.

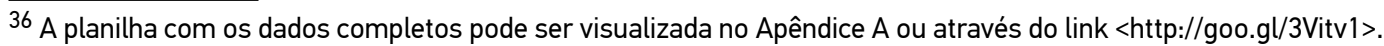




\subsubsection{AS EDITORIAS}

A revista Pesquisa FAPESP conta com cinco editorias principais:

a) Política $C \& T$, abordando assuntos relacionados a políticas de apoio à pesquisa;

b) Ciência, tratando primordialmente de pesquisas relativas às ciências naturais e da vida, como a astronomia, ecologia, física, medicina, química, zoologia, entre outras;

c) Tecnologia, enfatizando os aspectos tecnológicos envolvidos em ou resultantes de pesquisas, em geral aquelas ligadas às ciências exatas;

d) Humanidades, debatendo estudos concernentes às ciências humanas e sociais, como a antropologia, arqueologia, artes, educação, história, letras, música e urbanismo;

e) as matérias de Capa, geralmente abarcando temáticas que associam mais de uma editoria.

Observando os dados que levantamos sobre os recursos gráficos, ao agrupá-los conforme as seções da revista (Quadro 9), é possível identificar que a editoria com mais recursos gráficos é Ciência (com 454 incidências), seguida por Política C\&T (com 324), Tecnologia (com 289), Humanidades (com 226) e finalizando com as matérias de Capa (com 195). Tal classificação não é surpreendente, posto que corresponde à quantidade de páginas reservadas a cada uma dessas editorias: no período analisado, Ciência ocupou a maior quantidade de páginas, preenchendo uma média de 21 páginas por edição; ao passo que foram destinadas em média 13,85 páginas por edição para Política C\&T; 12,8 páginas para Tecnologia; 10,7 páginas para Humanidades e 8,1 páginas para as matérias de Capa (ver Figura 45) .

\section{Figura 45. Quantidade de páginas por editoria.}

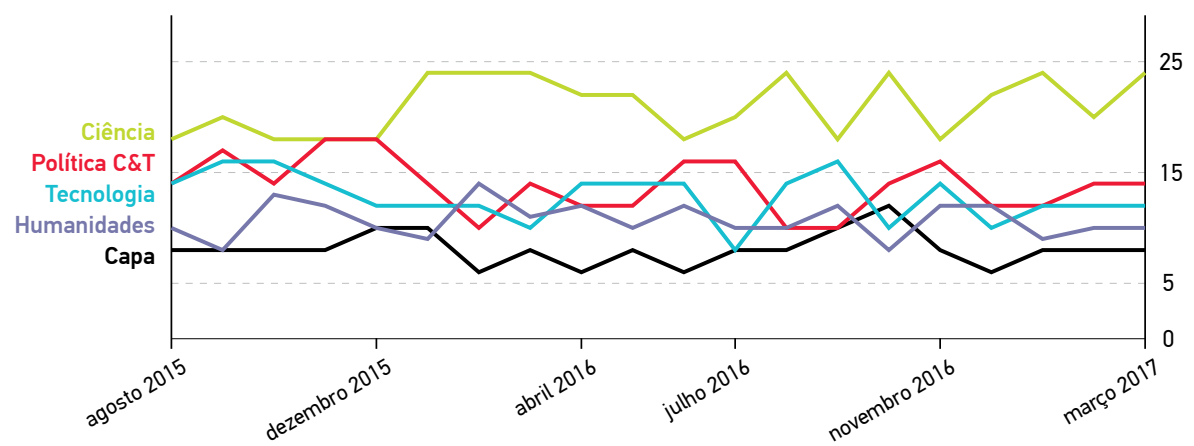

Fonte: Elaboração nossa. 
Quadro 9. Quantidade de recursos gráficos por editoria/seção.

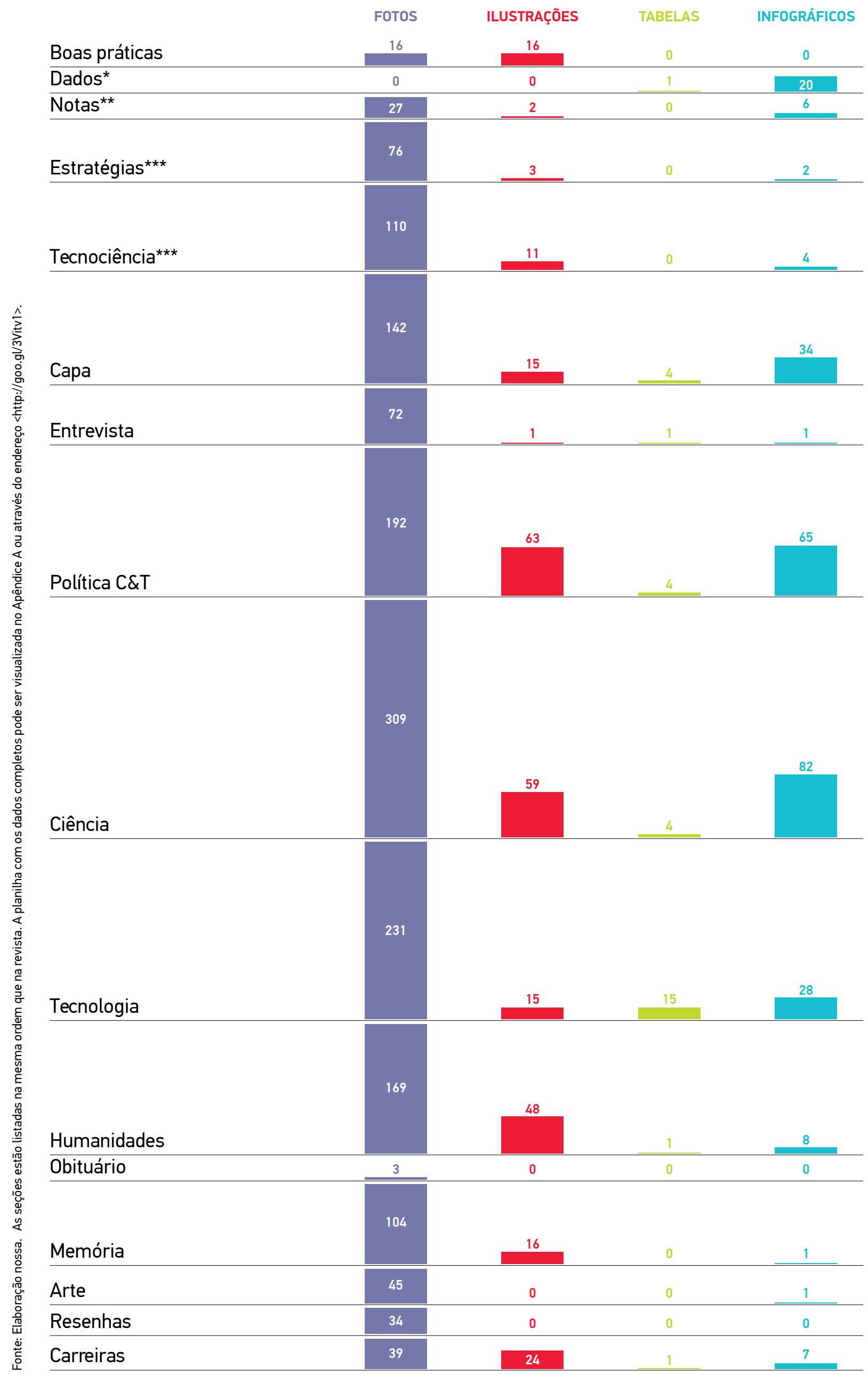


A quantidade de páginas reservadas a cada editoria, por sua vez, reflete os números referentes aos financiamentos da FAPESP. Em 2015, por exemplo, de $\mathrm{R} \$ 1,188$ bilhão que foi desembolsado pela fundação em apoio a projetos de pesquisa, $51 \%$ foi destinado a estudos das "Ciências da vida" (grupo mais próximo à editoria Ciência), 28\% a "Ciências exatas e da terra e engenharias" (categoria adjacente a Tecnologia), 11\% a "Ciências humanas e sociais" (classe correspondente a Humanidades), e 10\% a estudos interdisciplinares (FAPESP, 2016, p.24).

Analisando cada editoria individualmente, é possível perceber que Política C\&T tem, proporcionalmente à quantidade total de recursos gráficos, mais infográficos que as demais editorias: 20,06\% (vide Figura 46). Tal incidência provavelmente decorre do fato de os conteúdos de suas reportagens frequentemente abrangerem grandes quantidades de dados numéricos.

\section{Figura 46. Porcentagem de recursos gráficos} nas cinco editorias principais. 


\subsubsection{CLASSIFICAÇÃO DOS INFOGRÁFICOS}

A área ocupada por um infográfico na página de uma revista pode ser um indicativo de sua relevância no tocante ao conteúdo: "o aumento na quantidade e na qualidade da informação contemplada torna o infográfico mais necessário e mais representativo - e esse aumento frequentemente é acompanhado pela ampliação da área ocupada em relação à reportagem" (SILVEIRA, 2010, p.80). Na etapa subsequente da análise, portanto, adotou-se como critério o tamanho dos infográficos para subdividi-los em quatro categorias (ver Quadro 10):

$\mathrm{P}=$ ocupa menos que $30 \%$ da área total de uma página da revista

$M=$ ocupa de $30 \%$ até menos que $70 \%$ da área total de uma página da revista

G = ocupa de $70 \%$ a $100 \%$ da área total de uma página da revista

GG = ocupa mais que $100 \%$ da área total de uma página da revista

Levantando as quantidades de infográficos de cada uma destas categorias, foi possível identificar, no período analisado, a presença de 111 infográficos de tamanho 'P', 120 infográficos 'M', 23 infográficos ' $G$ ' e apenas 5 infográficos 'GG' (conforme Quadro 11). A predominância de infográficos ' $P$ ' e ' $M$ ' deve-se ao fato de as explanações visuais serem frequentemente fracionadas em infográficos menores, distribuídos ao longo da matéria e alocados em posições próximas aos trechos de texto a que se referem.

Por outro lado, infográficos ' $G$ ' e 'GG' geralmente combinam maiores quantidades de dados, abarcam conteúdo informativo mais extenso e possibilitam diferentes experimentações gráficas, incorporando elementos visuais variados - fatores que os tornam mais interessantes para a nossa pesquisa. Por tais motivos, no prosseguimento da análise, observamos de forma mais aprofundada apenas os infográficos de tamanhos ' $G$ ' e 'GG'.

Agrupando os dados sobre o tamanho dos infográficos conforme as seções da revista, percebe-se que há infográficos 'G' e 'GG' apenas em quatro editorias: Capa, Política C\&T, Ciência e Tecnologia (ver Quadro 12). A editoria Humanidades não contém infográficos 'G' e ‘GG' possivelmente por não apresentar conjuntos volumosos de dados quantitativos e por muitos de seus conteúdos de cunho sócio-cultural serem melhor representados por meio de fotografias. 
Quadro 10. Classificação dos infográficos por área.
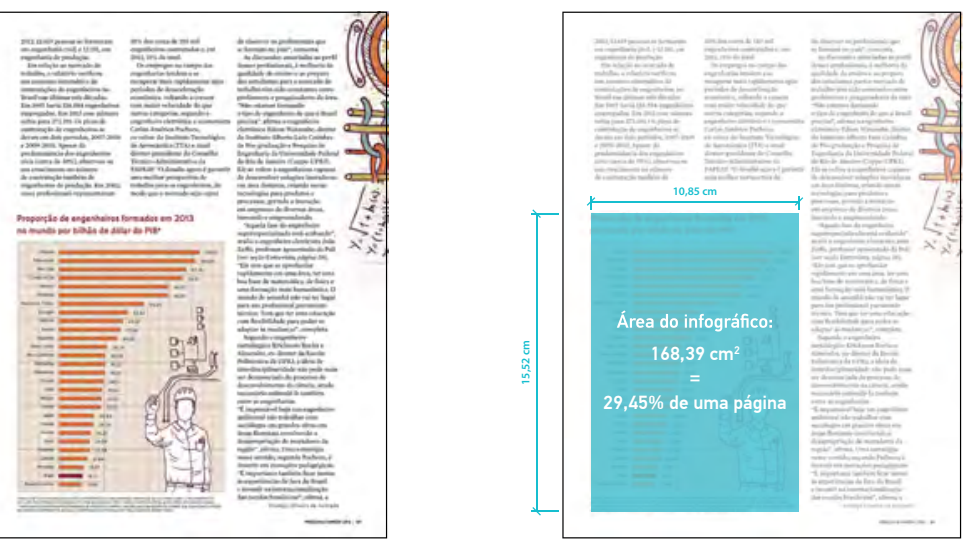

M 30\% a $<70 \%$ de uma página
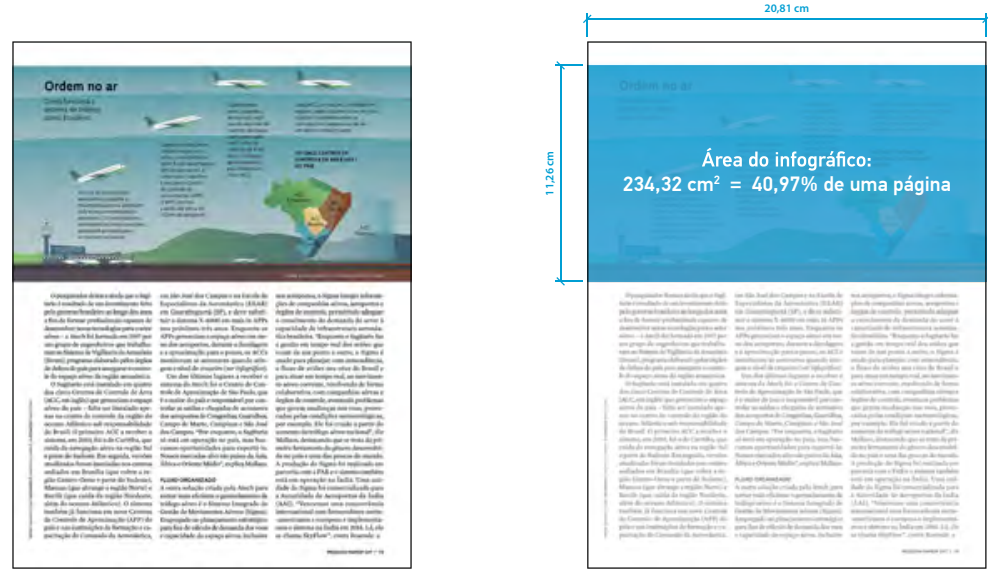

G $70 \%$ a $100 \%$ de uma página
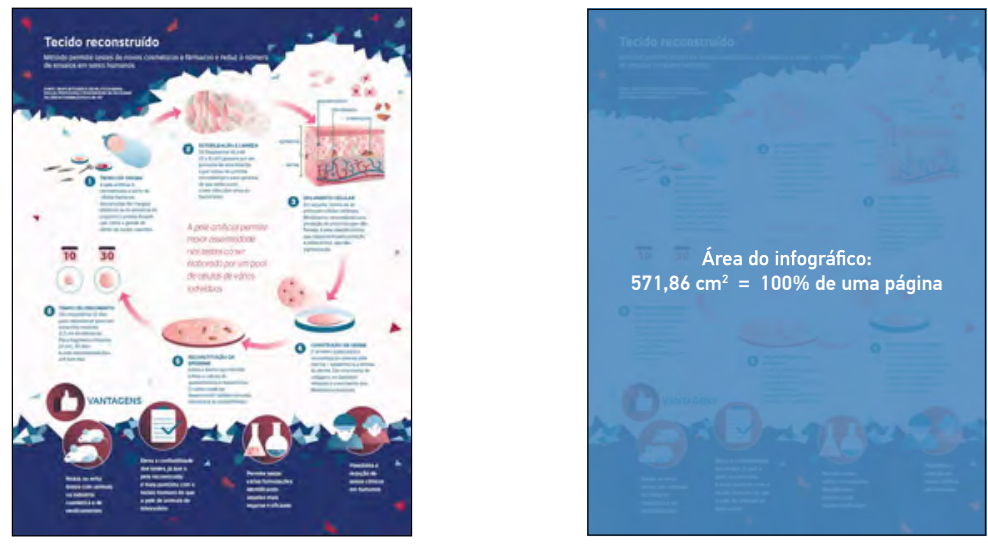

GG $>100 \%$ de uma página
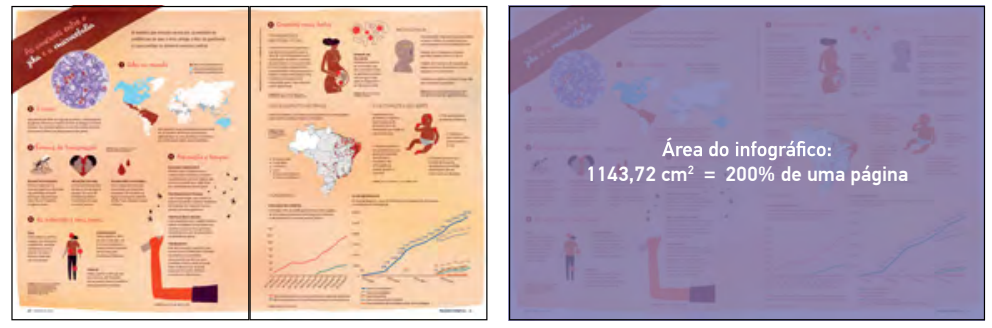

Fonte: Elaboração nossa. 


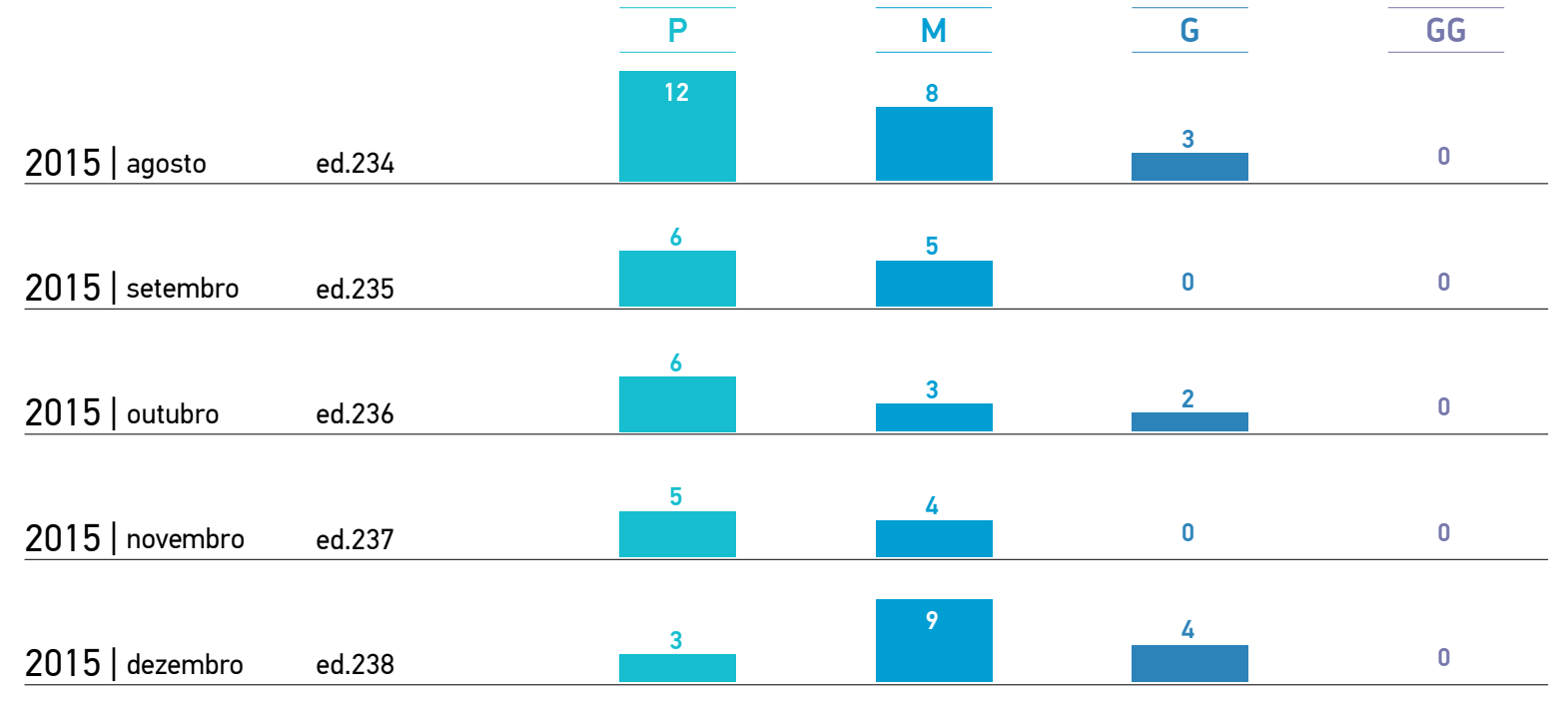

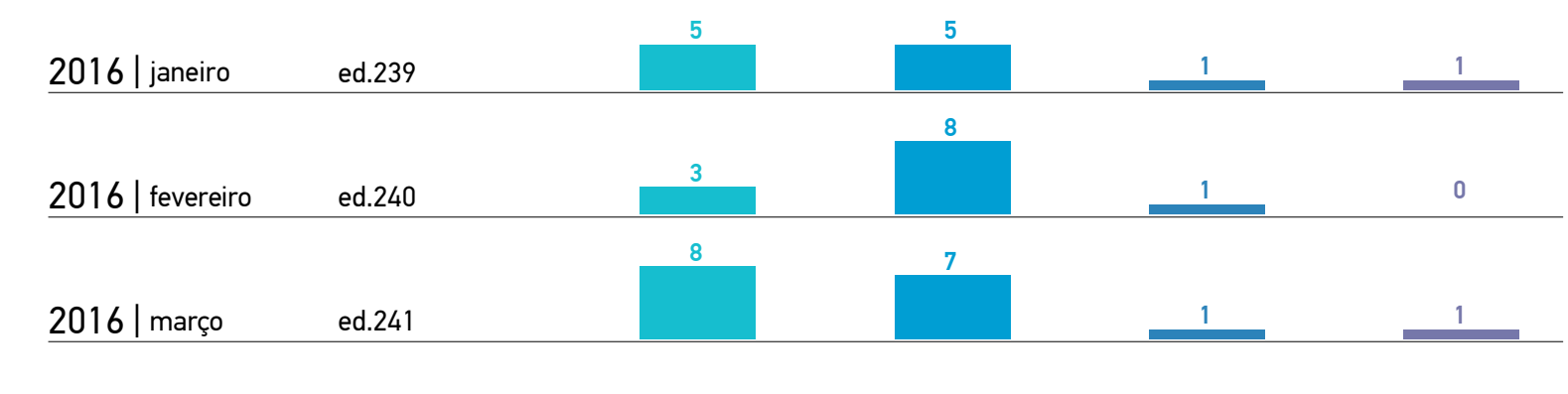

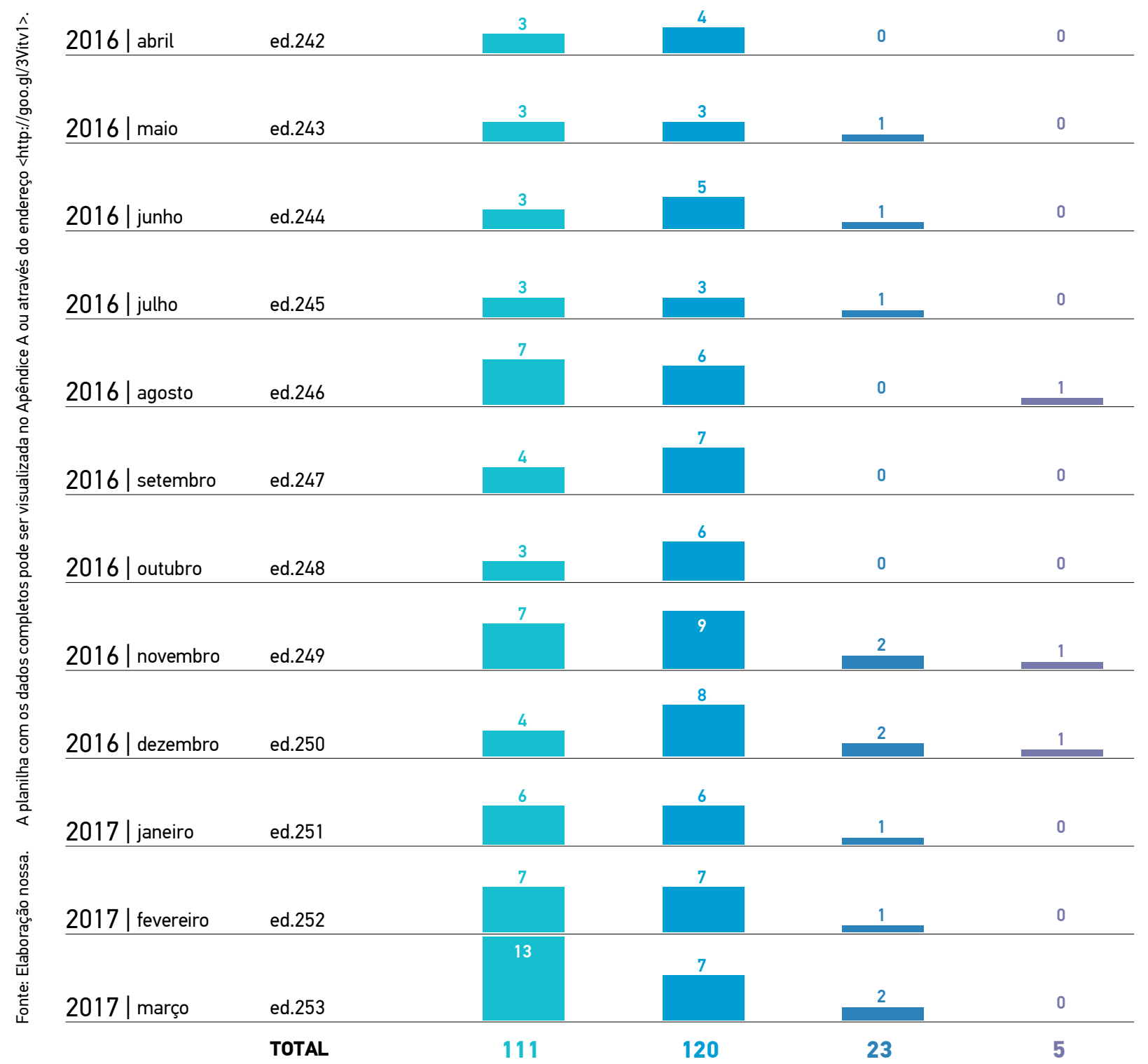




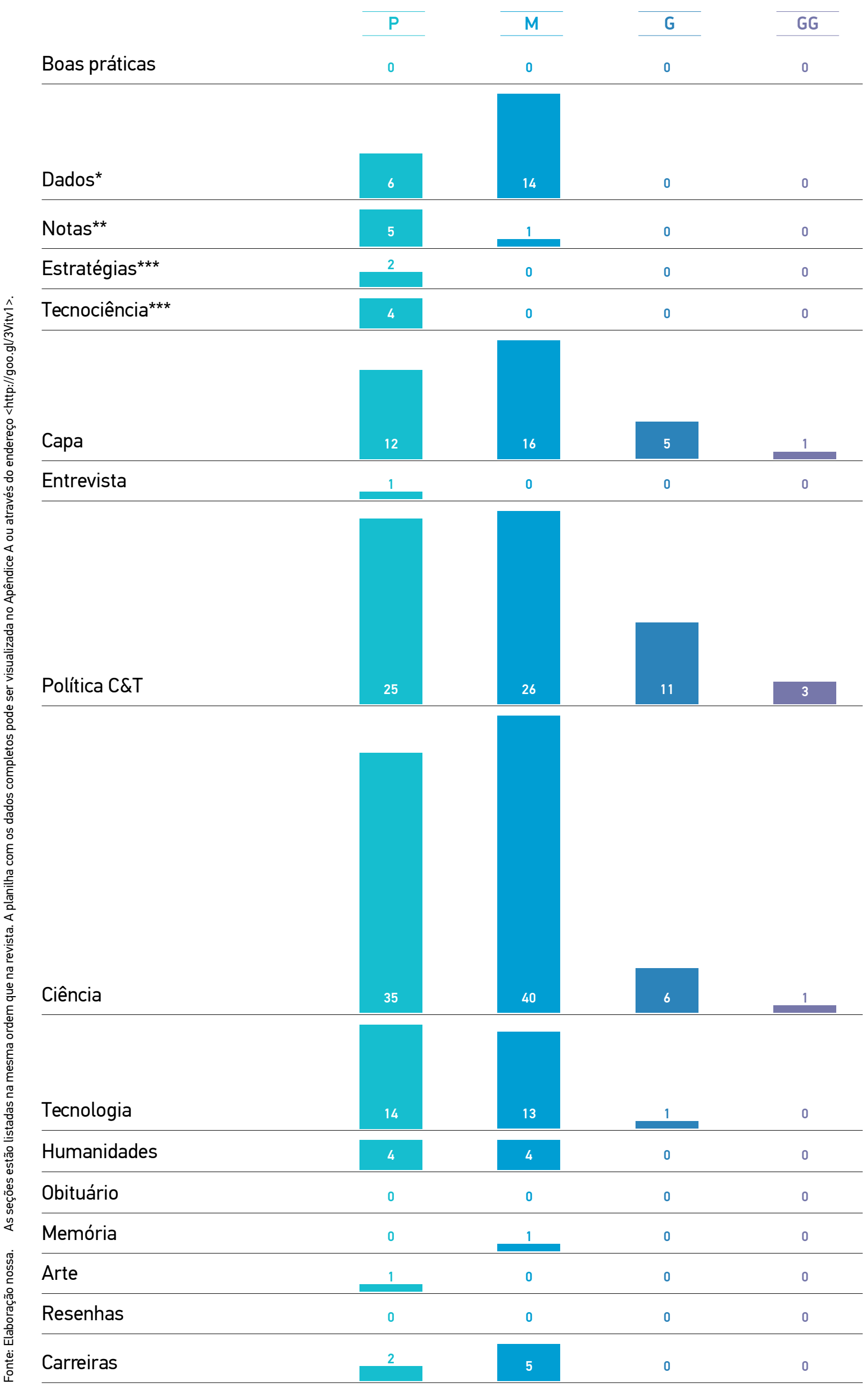




\section{2 \\ MODELO DE ANÁLISE}

Como mencionado anteriormente, o modelo de análise para infográficos aqui proposto toma como ponto de partido as três funções do design propostos por Mijksenaar e esmiuçados por nós no Capítulo 3: utilidade, confiabilidade e satisfação. Entendendo que o termo 'confiabilidade' pode induzir à ideia de que esteja em avaliação a veracidade dos dados e a credibilidade das fontes, preferimos substituir o termo 'confiabilidade' por 'precisão'. Desta forma, evidencia-se que pretendemos analisar apenas o grau de exatidão com que as informações são apresentadas, o nível de precisão empregado para evitar a interpretação errônea dos dados ilustrados.

A etapa seguinte consistiu no preenchimento de três Formulários de Análise, correspondentes aos três princípios de design. Os formulários preveem pontuações numéricas, o que permite que a documentação e posteriores avaliações comparativas sejam realizadas de forma mais objetiva.

A cada critério de avaliação, portanto, foram conferidas pontuações que variam de 0 a 2 . A adoção de uma escala (ao invés de valores binários) deveu-se à natureza gradiente do processo comunicacional:

"Não parece ocorrer, na sociedade, uma alternativa mutuamente excludente entre uma comunicação perfeita e uma ausência radical de comunicação. Estas duas possibilidades seriam apenas os extremos abstratos de uma dimensão contínua, com graus, níveis e direções variáveis de atingimento."

(BRAGA, 2012, p.34)

0 primeiro formulário de análise, relativo à utilidade do infográfico, avalia a medida em que o dispositivo fornece ao leitor ferramentas proficientes para a compreensão ou interpretação do conteúdo informativo da reportagem: 
Quadro 13. Formulário de Análise: UTILIDADE

U1 - FUNÇÃO/PROFICUIDADE. O infográfico:

Não é facilmente compreendido sem a leitura da reportagem.

Auxilia na compreensão da reportagem ou no endossamento dos argumentos apresentados.

É bastante útil para a compreensão e endossamento da reportagem, fornecendo

dados complementares ou elementos comparativos.

elou

Permite novas leituras do conteúdo informativo (além daquelas já apresentadas no texto da reportagem).

\section{U2 - ORGANIZAÇÃO. A estrutura do infográfico:}

É confusa, exigindo mais de uma análise até que se identifique o sistema de ordenação de seu conteúdo.

É identificada com certa facilidade, mas apresenta dados incompletos, em demasia ou insuficientes, prejudicando a assimilação do conteúdo.

elou

A lógica de ordenação dos elementos não é clara.

elou

A complexidade excessiva demanda o fornecimento de instruções.

É identificada rapidamente e sem ambiguidade. Há elementos gráficos que direcionam a sequência de leitura, destacam pontos-chave e/ou evidenciam a hierarquia do conteúdo.

U3 - ICONOGRAFIA. Os símbolos e figuras empregados são facilmente reconhecíveis, pertencendo ao repertório do senso comum?:

\begin{tabular}{|l|c|}
\hline Não. & 0 \\
\hline Parcialmente. & 1 \\
\hline Sim, plenamente. & 2 \\
\hline
\end{tabular}

U4 - LINGUAGEM VERBAL DO INFOGRÁFICO. 0 vocabulário empregado no infográfico:

Inclui termos técnicos muito específicos, linguagem rebuscada e/ou construções gramaticais complexas.

Inclui termos técnicos, mas a linguagem é objetiva.

É claro e acessível para o leitor leigo.

U5 - IDENTIFICAÇÃOO. 0 título (e eventuais subtítulos) do infográfico reflete(m) adequadamente o conteúdo?:

Não (ou não há título).

Parcialmente.

Sim, plenamente.

O segundo formulário de análise, correspondente à precisão do infográfico, permite observar se a representação gráfica dos dados é adequada ao conteúdo, assegurando uma interpretação coerente e inequívoca por parte do leitor: 


\section{Quadro 14. Formulário de Análise: PRECISÃo}

P1 - INTEGRIDADE. Quanto à representação do conteúdo:

Há contradições entre o texto da reportagem e os dados no infográfico.

e/ou

Dados são vagos e valores numéricos são muito arredondados.

e/ou

Há falhas na representação de objetos e valores (como distanciamento irregular em linhas do tempo,

áreas desproporcionais aos valores representados, perspectivas que prejudicam a percepção,

formas e cores incompatíveis com o objeto real, etc.).

Não há falhas evidentes na representação de objetos e valores.

0 infográfico permite uma leitura precisa e sem ambiguidades. Não há falhas na representação de objetos e valores. São fornecidos elementos de reforço, como a indicação de escala e orientação (em mapas),

elementos de referência representados em tamanho real (1:1) ou a escala ampliada (zoom) para

refinar a visualização de um ou mais aspectos do conteúdo informativo.

\section{P2 - FORMATO. 0 formato do(s) gráfico(s) - gráfico de barras, fluxograma, mapa de localização, gráfico relacional, etc. -} é(são) adequado(s) para a representação do conteúdo informativo e das relações entre os dados?:

Não. O(s) formato(s) selecionado(s) não revela(m) o conteúdo informativo e/ou não evidenciam as relações entre os elementos.

O(s) formato(s) permite $(m)$ a visualização do conteúdo informativo, mas outro modo de organização poderia ser mais profícuo.

Sim, o(s) formato(s) favorece(m) a visualização do conteúdo e/ou das relações entre elementos.

\section{P3 - LEGENDAS. Quanto à orientação ao leitor por meio de rotulagem e legendas:}

Legendas e rótulos são ausentes ou insuficientes, dificultando a compreensão do conteúdo informativo; ou pontos de interesse não estão indicados.

Legendas e rótulos são incompletos; ou textos explicativos são demasiadamente longos, desencorajando sua leitura.

Legendas são claras e completas, possibilitando a compreensão do conteúdo.

Rótulos indicam todos os pontos relevantes para a análise das informações apresentadas.

\section{P4 - LEGIBILIDADE. Quanto à definição dos elementos gráficos:}

A legibilidade é comprometida pelo tamanho reduzido das letras, pelo tipo de fonte tipográfica empregada e pelo pouco contraste cromático. Elementos como traços e contornos são muito finos, dificultando sua percepção.

Apenas um dos elementos (tipografia, linhas ou cores) apresentam definição falha.

0 estilo e tamanho da tipografia foram determinados com rigor, favorecendo a leitura.

As cores são suficientemente contrastantes, possibilitando uma diferenciação e leitura confortáveis.

Linhas são suficientemente espessas, garantindo visibilidade.

\section{P5 - REFERÊNCIAS. As fontes ou créditos originais dos dados:}

Não são indicadas.

São indicadas, mas de forma simplificada (fornecendo, por exemplo, apenas o nome do pesquisador responsável).

São indicadas de forma completa (fornecendo dados completos sobre o projeto ou endereço(s) eletrônico(s) para consulta). 
No último formulário de análise, correspondente à satisfação, os itens levantados possibilitam avaliar o quanto o aspecto visual do infográfico se presta a aprazer esteticamente e atrair a atenção do observador, motivando a leitura do texto da reportagem:

\section{Quadro 15. Formulário de Análise: SATISFAÇÃo}

S1 - ATRATIVIDADE. 0 aspecto visual do infográfico atrai a atenção, motivando a leitura do texto da reportagem?: Pontos

Não. Com tamanho reduzido e elementos pouco marcantes, o infográfico não gera impacto visual.

Parcialmente. 0 infográfico emprega um ou mais recursos visuais interessantes, mas que não necessariamente impulsionam a leitura da reportagem.

Sim. 0 infográfico é visualmente atraente (por conta de uma imagem chamativa, de cores contrastantes, de assimetrias marcantes, ou de um conceito interessante ou bem-humorado). Seu impacto visual agrega valor à percepção da reportagem como um todo. 0 infográfico ocupa mais da metade da área de uma página.

\section{1}

S2 - APRESENTAÇÃO. Quanto à apresentação visual, verifica-se que:

A seleção de cores e imagens é arbitrária e dissonante. 0 estilo do infográfico não acompanha o projeto gráfico da revista.

Há certo apuro nos elementos visuais, mas falta equilíbrio na composição ou na seleção imagética.

As ilustrações são bem elaboradas e coerentes com o estilo visual e temática da reportagem.

As cores foram selecionadas com rigor e o infográfico está diagramado de forma esmerada, integrando-se harmoniosamente na(s) página(s).

S3 - ORNAMENTAÇÃO. Há elementos com função primordialmente decorativa?

Não

Sim, empregados de forma discreta.

Sim, ocupando área equivalente ou maior que aquela ocupada por elementos com função informativa específica.

\section{S4 - TEMATIZAÇÃO DE FONTES. As fontes tipográficas empregadas no infográfico:}

São as mesmas utilizadas no restante da revista, sem apresentar características especiais (como um detalhe decorativo, uma orientação diferenciada, ou cores e tamanhos marcantes).

São as mesmas utilizadas no restante da revista, mas são empregadas com cores, tamanhos e/ou posicionamentos que evidenciam títulos ou textos de destaque.

São bastante diferenciadas. São utilizadas fontes mais temáticas, que aludem ao tópico da reportagem.

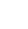




\subsubsection{EXEMPLO DE APLICAÇÃO}

\section{Figura 47. Infográfico Produção biotecnológica de animais transgênicos.}

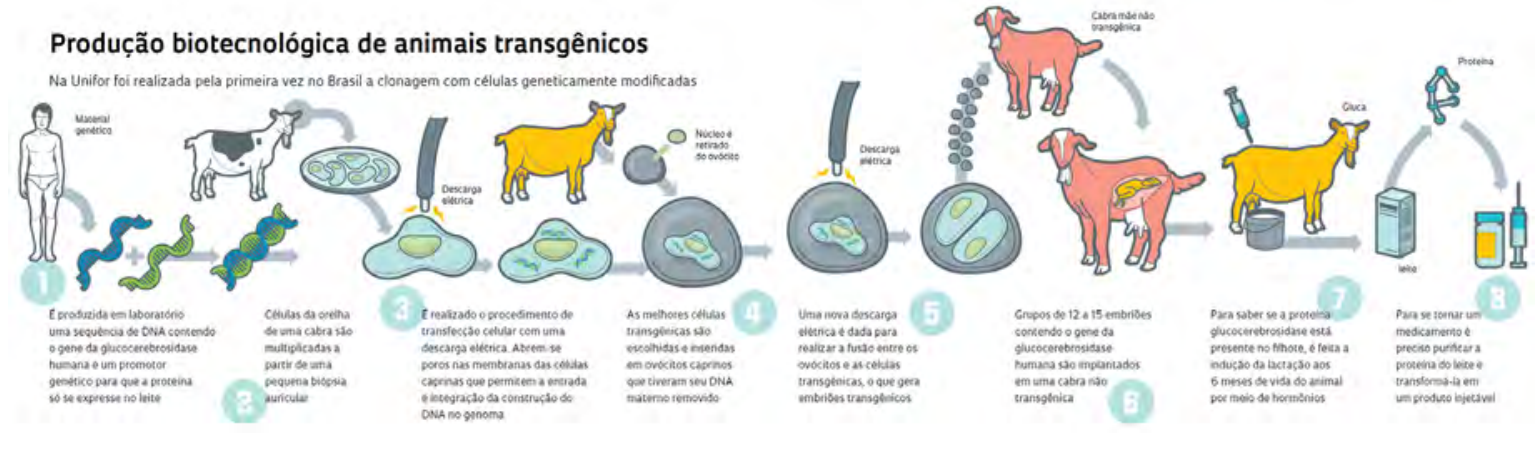

Fonte: Revista Pesquisa FAPESP, edição n 236, out. 2015.

Como modelo de emprego dos formulários, apresentamos o infográfico Produção biotecnológica de animais transgênicos (Figura 47), presente na matéria Cabras transgênicas, da edição no 236 (out/2015). No exemplo, descreve-se um processo de clonagem animal a partir de células geneticamente modificadas.

Estruturado como uma sequência ilustrada, o infográfico apresenta alto índice de utilidade (10 pontos) ao descrever e explanar cada etapa de um método complexo que foi resumido no texto da reportagem. A pontuação foi obtida a partir das seguintes respostas ao formulário:

\section{UTILIDADE U1 - FUNÇÃO/PROFICUIDADE. 0 infográfico:}

É bastante útil para a compreensão e endossamento da reportagem, fornecendo dados complementares ou elementos comparativos. (2 pontos)

U2 - ORGANIZAÇÃO. A estrutura do infográfico:

É identificada rapidamente e sem ambiguidade. Há elementos gráficos que direcionam a sequência de leitura, destacam pontos-chave e/ou evidenciam a hierarquia do conteúdo. ( 2 pontos)

U3 - ICONOGRAFIA. Os símbolos e figuras empregados são facilmente reconhecíveis, pertencendo ao repertório do senso comum?:

Sim, plenamente. (2 pontos)

U4 - LINGUAGEM VERBAL DO INFOGRÁFICO. 0 vocabulário empregado no infográfico:

É claro e acessível para o leitor leigo. (2 pontos)

U5 - IDENTIFICAÇÃO. 0 título (e eventuais subtítulos) do infográfico reflete(m) adequadamente o conteúdo?:

Sim, plenamente. (2 pontos)

TOTAL: 10 pontos 
0 grau de precisão também é bom (8 pontos), por fornecer detalhes concernentes ao procedimento (incluindo alguns termos técnicos) sem apresentar falhas significativas de representação gráfica. A leitura inequívoca é assegurada, por exemplo, pela atribuição de cores distintas a cada uma das cabras envolvidas no processo, evitando-se confusão na compreensão da sucessão dos eventos:

PRECISÃo P1 - INTEGRIDADE. Quanto à representação do conteúdo: Não há falhas evidentes na representação de objetos e valores. (1 ponto)

P2 - FORMATO. 0 formato do(s) gráfico(s) é(são) adequado(s) para a representação do conteúdo informativo e das relações entre os dados?:

Sim, o(s) formato(s) favorece(m) a visualização do conteúdo e/ou das relações entre elementos. (2 pontos)

P3 - LEGENDAS. Quanto à orientação ao leitor por meio de rotulagem e legendas:

Legendas são claras e completas, possibilitando a compreensão do conteúdo. Rótulos indicam todos os pontos relevantes para a análise das informações apresentadas. (2 pontos)

P4 - LEGIBILIDADE. Quanto à definição dos elementos gráficos:

0 estilo e tamanho da tipografia foram determinados com rigor, favorecendo a leitura. As cores são suficientemente contrastantes, possibilitando uma diferenciação e leitura confortáveis. Linhas são suficientemente espessas, garantindo visibilidade. (2 pontos)

P5 - REFERÊNCIAS. As fontes ou créditos originais dos dados:

São indicadas, mas de forma simplificada (fornecendo, por exemplo, apenas o nome do pesquisador responsável). (1 ponto)

TOTAL: 8 pontos

Assim como os dois primeiros índices, o grau de satisfação (7 pontos) também está acima da média (6,18 pontos). As ilustrações e cores foram selecionadas com rigor e o infográfico está diagramado de forma equilibrada e atraente:

SATISFAÇÃO S1 - ATRATIVIDADE. 0 aspecto visual do infográfico atrai a atenção, motivando a leitura do texto da reportagem?:

Sim. 0 infográfico é visualmente atraente (por conta de uma imagem chamativa, de cores contrastantes, de assimetrias marcantes, ou de um conceito interessante ou bem-humorado). Seu impacto visual agrega valor à percepção da reportagem como um todo. 0 infográfico ocupa mais da metade da área de uma página. (2 pontos)

S2 - APRESENTAÇÃO. Quanto à apresentação visual, verifica-se que:

As ilustrações são bem elaboradas e coerentes com o estilo visual e temática da reportagem. As cores foram selecionadas com rigor e o infográfico está diagramado de forma esmerada, integrando-se harmoniosamente na(s) página(s). (2 pontos) 
S3 - ORNAMENTAÇÃO. Há elementos com função primordialmente decorativa? Não. (O pontos)

S4 - TEMATIZAÇÃO DE FONTES. As fontes tipográficas empregadas no infográfico:

São as mesmas utilizadas no restante da revista, mas são empregadas com cores, tamanhos e/ou posicionamentos que evidenciam títulos ou textos de destaque. (1 ponto)

S5 - SIMPLICIDADE/CONCISÃO. Quanto à quantidade de informações visuais apresentadas:

É apresentada apenas a quantidade de dados necessária para a assimilação e avaliação do conteúdo. Imagens complexas são utilizadas apenas quando estritamente necessárias para a compreensão do conteúdo, e elementos prioritários são indicados. Em todos os outros casos, há uma simplificação de formas e figuras, de modo a facilitar a visualização e evitar o excesso de ruídos. (2 pontos)

TOTAL: 7 pontos

0 gráfico resultante dos dados computados está representado na Figura 48. Não seguimos o modelo visual de Mijksenaar (composto por três termômetros em ângulos de $120^{\circ}$ ) porque o gráfico em barras paralelas permite melhor comparação entre os valores.

Figura 48. Resultado da análise para o infográfico Produção biotecnológica de animais transgênicos.

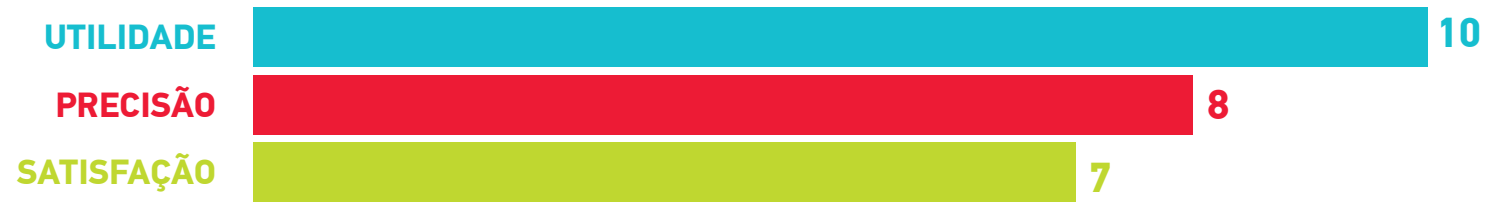

Fonte: Elaboração nossa.

\subsubsection{APLICAÇÃO AO CORPUS}

0 modelo de análise foi aplicado a todos os infográficos de tamanho 'G' ou 'GG' constatados na revista Pesquisa FAPESP durante o período analisado (agosto de 2015 a março de 2017), conforme listados no Quadro 16. Os resultados geraram os gráficos que podem ser observados no Quadro 17. (As tabelas com os dados completos podem ser visualizadas no Apêndice B ou pelo link $<$ https://goo.gl/WyscV9>.) 
Quadro 16-A. Infográficos 'G' e ‘GG', aos quais foi aplicado o modelo de análise* (continua na próxima página)
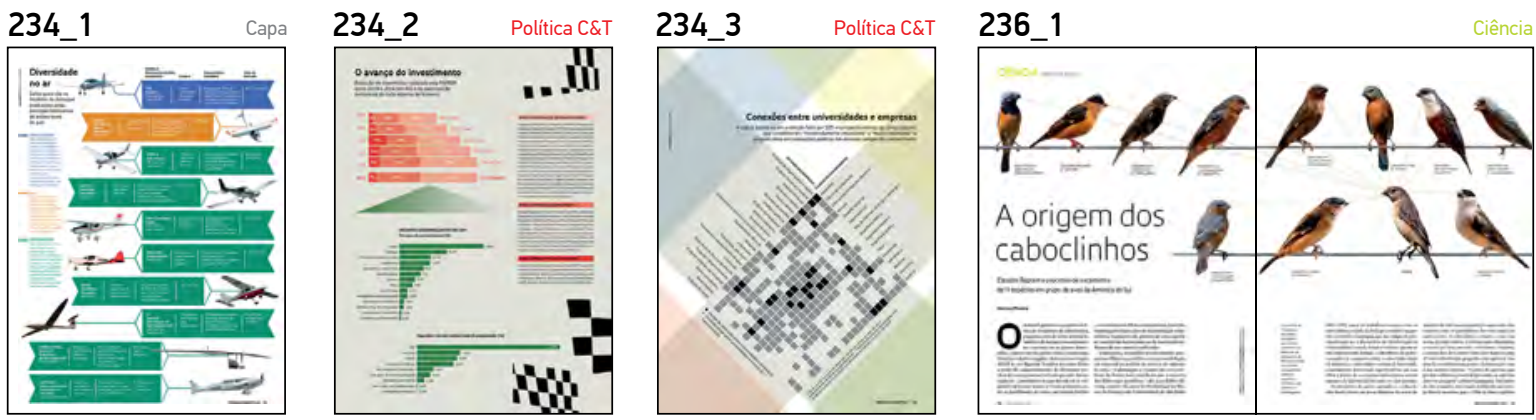

236_2

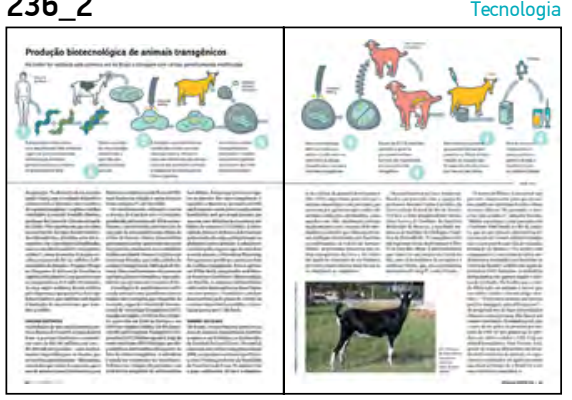

$238 \_2$
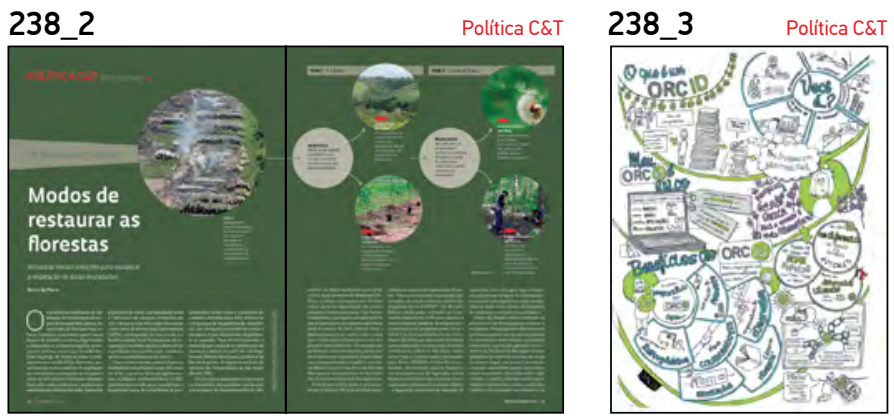

238_1

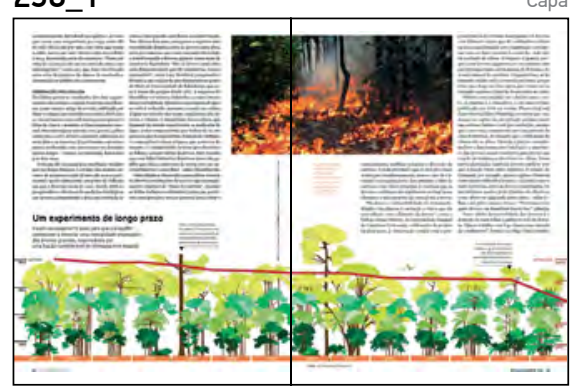

239_1

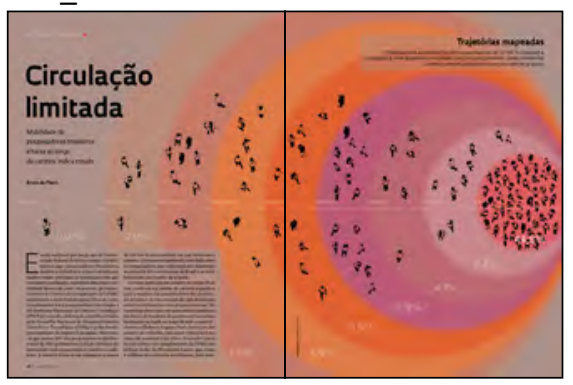

$$
241
$$

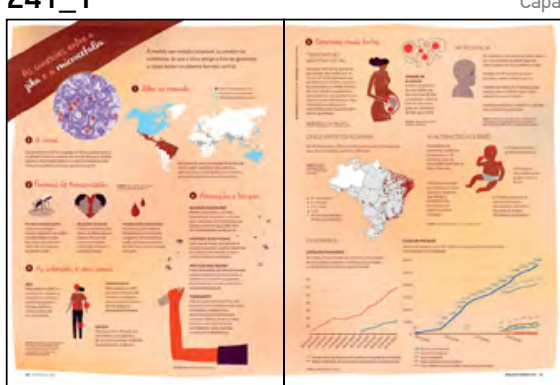

\section{9_2}
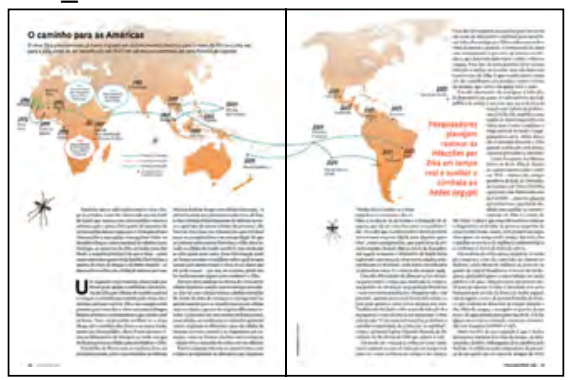

241_2

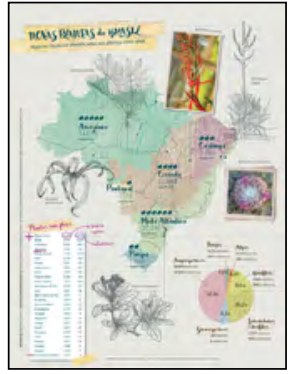

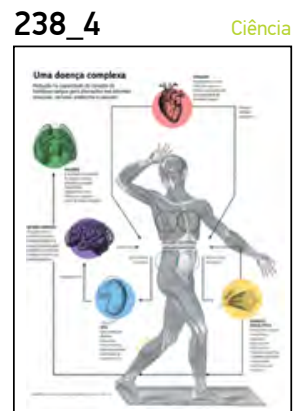
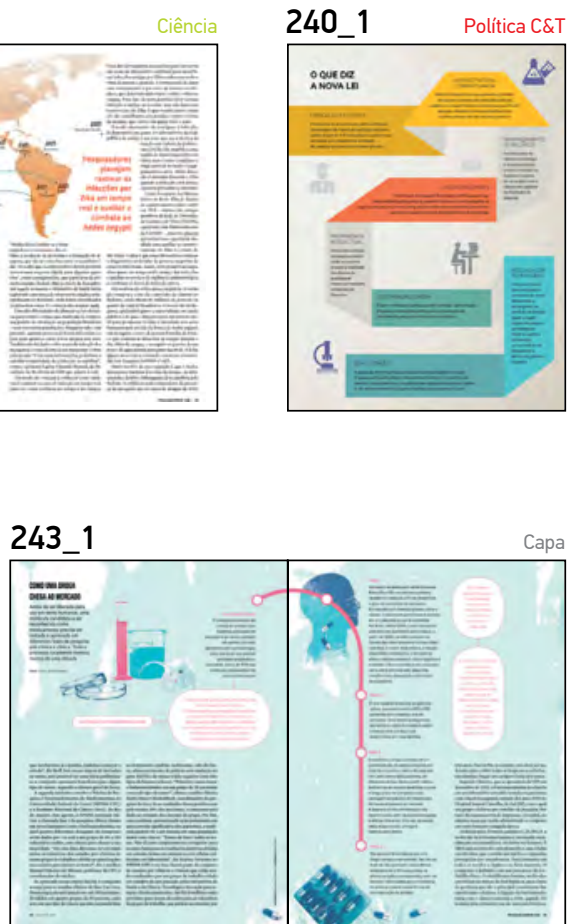
Quadro 16-B. Infográficos 'G' e 'GG', aos quais foi aplicado o modelo de análise* (continuação)
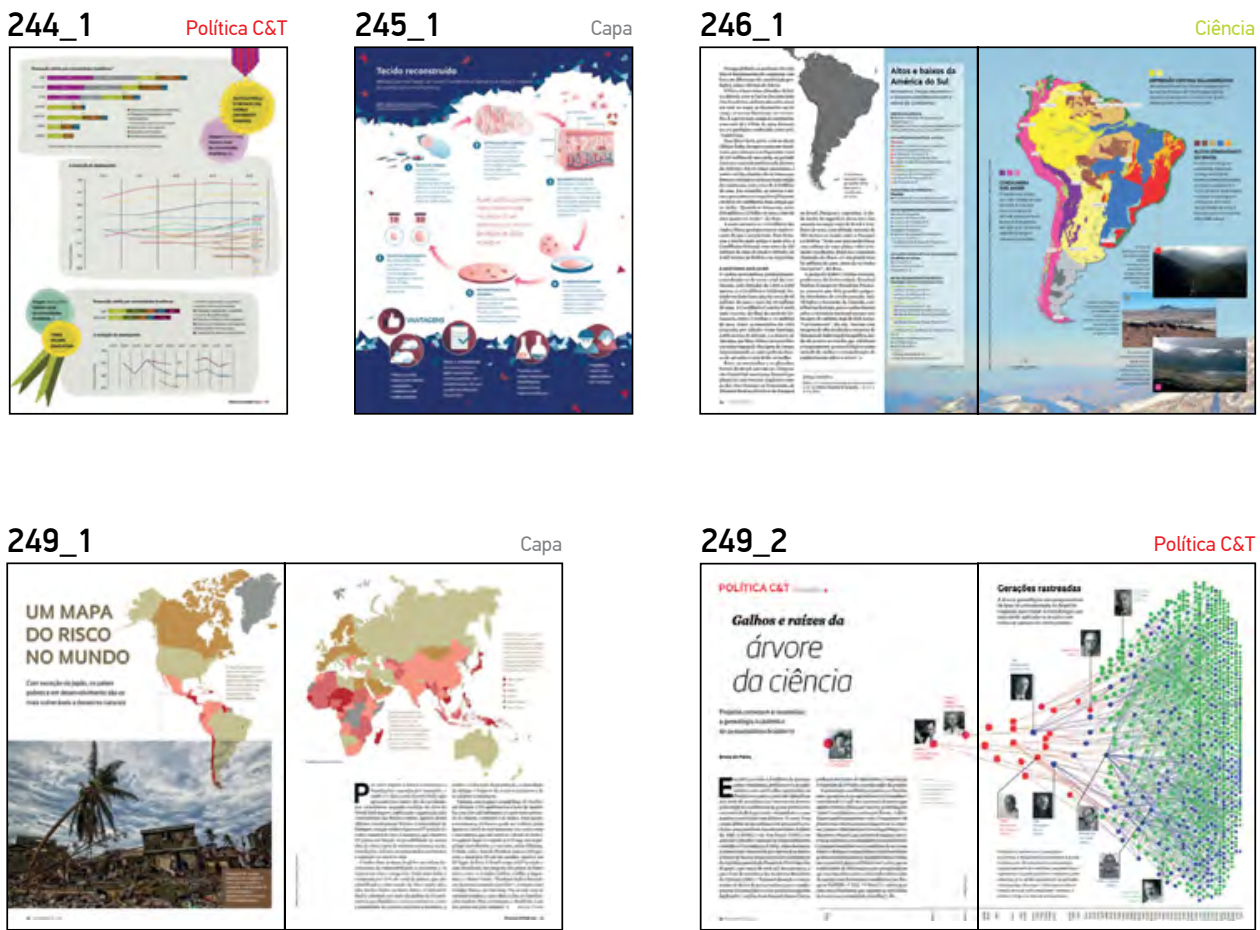

249_3

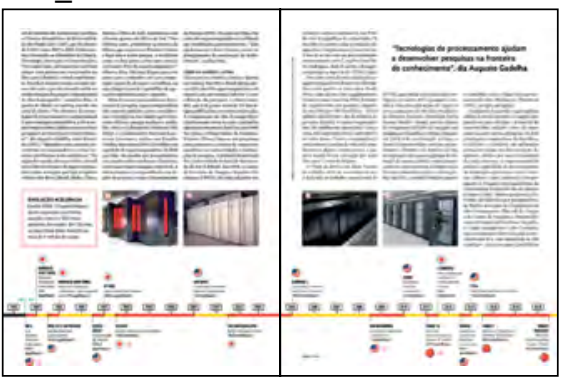

250_1

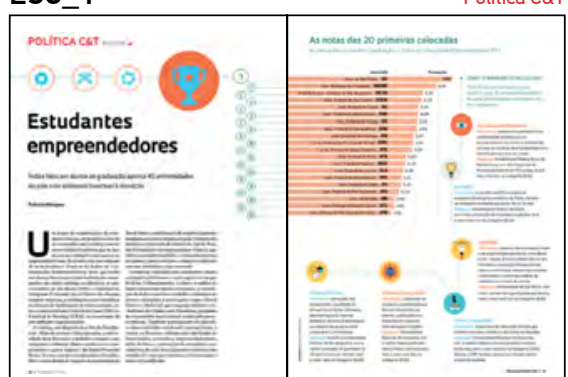

250_3

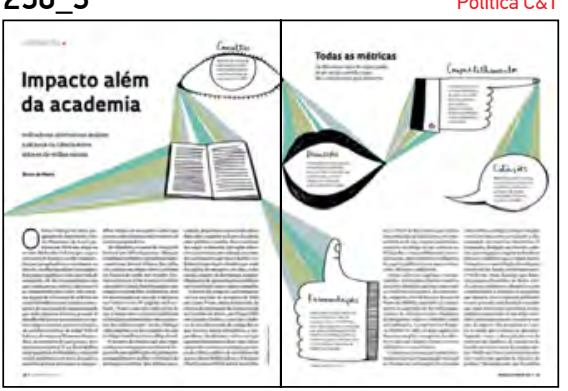

$251+1$

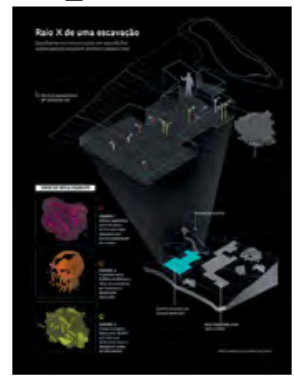

253_1

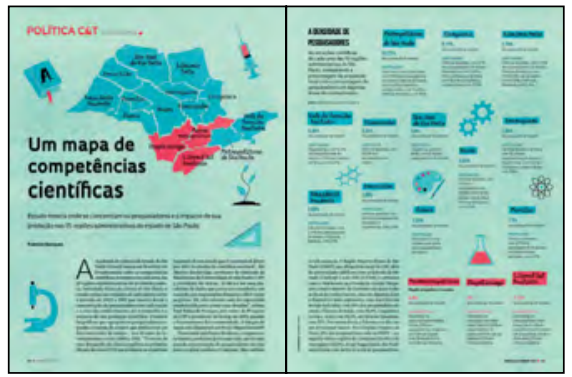

249
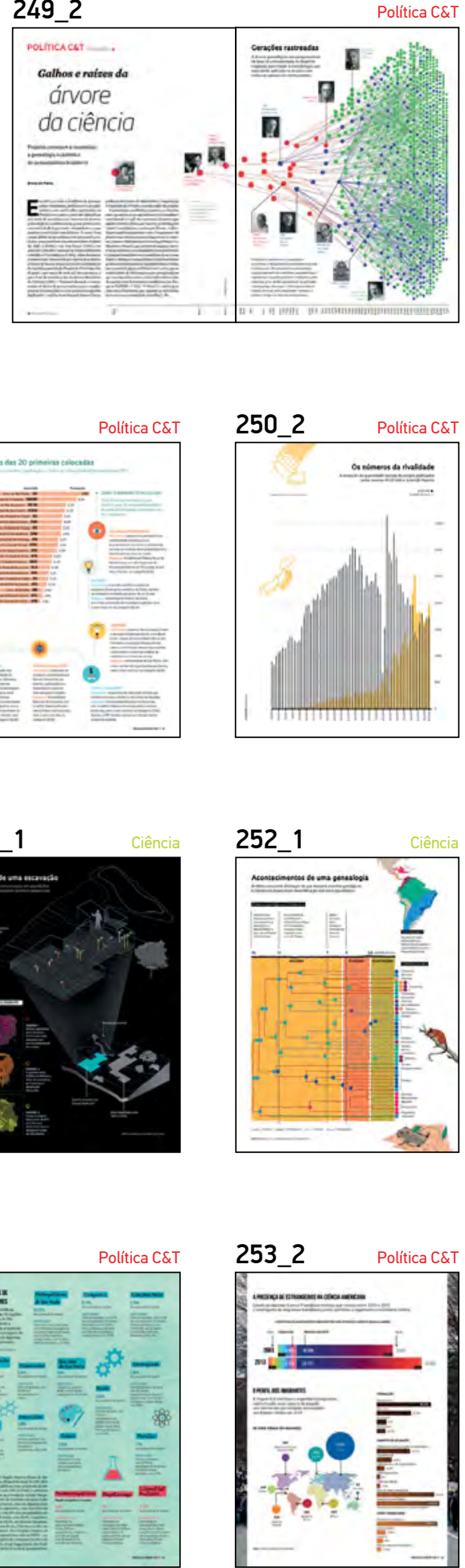
Quadro 17. Resultados individuais dos Formulários de Análise aplicados aos infográficos 'G' e 'GG'
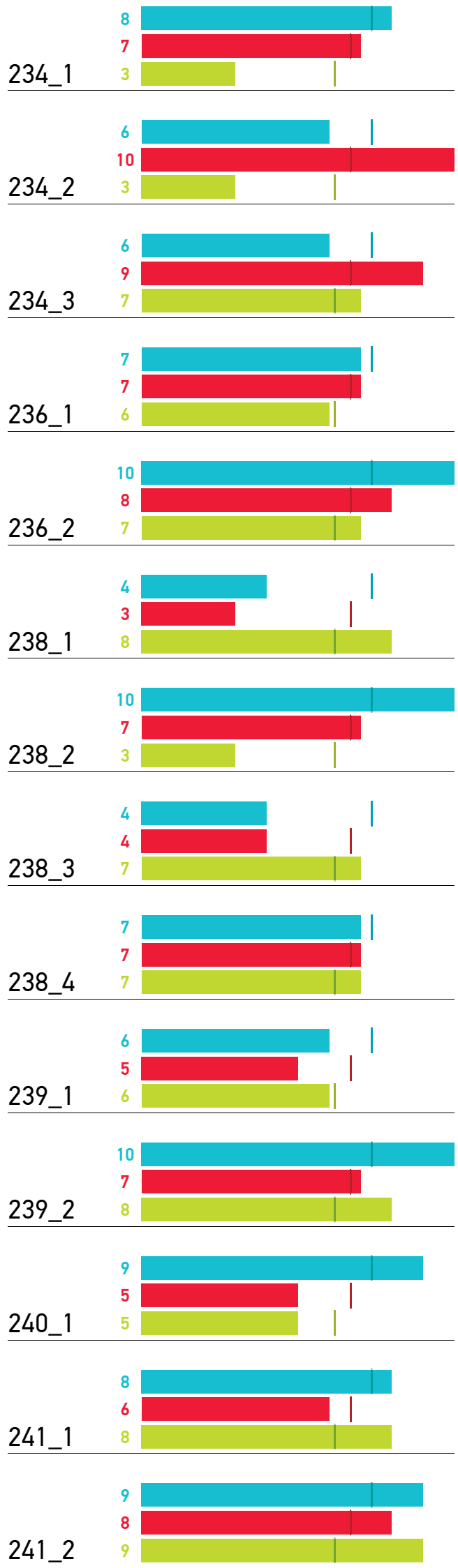
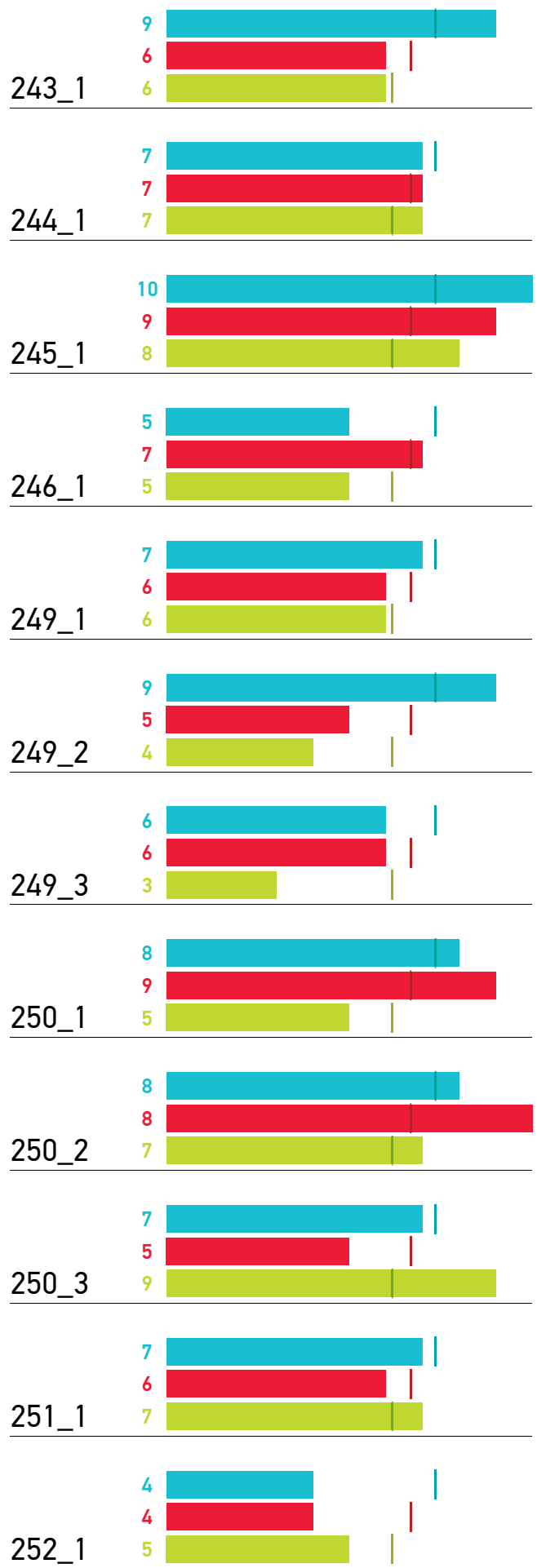

253_1

253_2

A planilha com os dados completos pode ser visualizada no Apêndice B. Fonte: Elaboração nossa. 
É possível perceber certo equilíbrio entre as três funções infográficas, que atingiram índices médios relativamente aproximados: 7,36 pontos para 'Utilidade', 6,68 pontos para 'Precisão' e 6,18 pontos para 'Satisfação' (ver Figura 49).

Figura 49. Resultados dos Formulários de Análise aplicados aos infográficos ' $G$ ' e 'GG'

PONTUAÇÃO TOTAL (soma dos resultados de todos os infográficos analisados)

\begin{tabular}{lll|l} 
ÍNDICE MÉDIO GERAL & UTILIDADE & 7,36 \\
& PRECISÃO & 6,68 \\
& SATISFAÇÃO & 6,18
\end{tabular}

Fonte: Elaboração nossa. A planilha com os dados completos pode ser visualizada no Apêndice B.

Tal ordem de classificação mostra-se bastante positiva: o fato de o índice mais alto ser relativo à função ‘Utilidade' indica coerência com a proposta de didatismo da Divulgação Científica. Já a função 'Precisão', apesar de necessária considerando-se a natureza dos conteúdos representados, é mais alinhada com o gênero da Comunicação Científica interpares, na qual apresentam-se dados em maior quantidade e com maior grau de exatidão. Semelhantemente, a função 'Satisfação' também agrega valor à divulgação da ciência, mas não deve ser o foco principal. 


\section{Figura 50. Resultados dos Formulários de Análise agrupados por Editoria}

\section{Capa}

(6 infográficos)

Política C\&T

(14 infográficos)

Ciência

(7 infográficos)

Tecnologia

(1 infográfico)
46

37

39

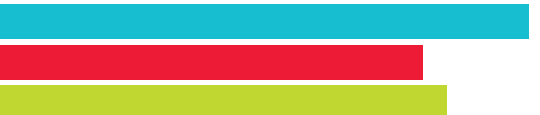

101

80

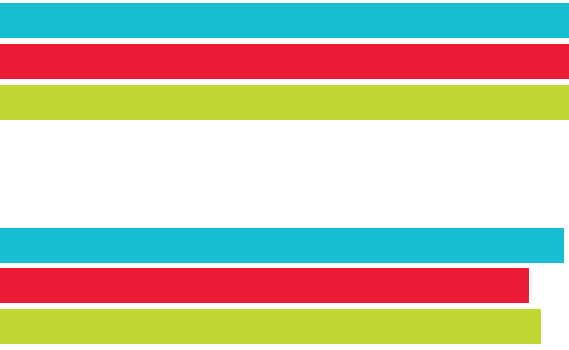

Ao agrupar os infográficos por editoria, é possível perceber uma variação maior dos índices (conforme a Figura 50). A 'Utilidade’ mantém-se como função prioritária nas quatro editorias verificadas, mas 'Precisão' e 'Satisfação' surgem de forma alternada na segunda e terceira posições.

Nas matérias de Capa, o índice de 'Satisfação' é superior ao de 'Precisão', possivelmente por tratar-se das reportagens chamariz de cada edição, que, além de sua atratividade natural, são geralmente mais longas e abarcam conteúdos mais amplos: "Gráficos com conteúdo complexo muitas vezes recebem mais trabalho de caráter estético porque demandam mais atenção da equipe de arte do veículo em sua construção" (SILVEIRA, 2010, p.82).

As reportagens da editoria Política $C \& T$ envolvem muitos dados quantitativos, provável motivo pelo qual o índice de 'Precisão' está significativamente acima de 'Satisfação' (seis pontos). Já as matérias de Ciência e de Tecnologia apresentam conteúdos com características variáveis, resultando em índices médios muito próximos para as três funções mensuradas. 


\subsubsection{TIPOS DE CONTEÚDO}

No processo de levantamento foram também documentados os tipos de conteúdo representados em cada infográfico e os formatos empregados (conforme as categorias determinadas a partir de Tufte, Roam e Kanno no Capítulo 3). Alguns exemplares são compostos por dois ou mais gráficos complementares, de forma que computamos separadamente o tipo de conteúdo principal e secundários; assim como o formato principal e secundários.

Dentro do período analisado, constatamos sete tipos de conteúdos principais (ver Figura 51). Dados quantitativos foi o tipo mais recorrente, sendo representado em mais da metade das ocasiões por gráficos de barras. Os mapas, segundo formato mais frequente no corpus, compõem 100\% dos infográficos que representam Posição no espaço.

Figura 51. Tipos de Conteúdos representados nos infográficos analisados

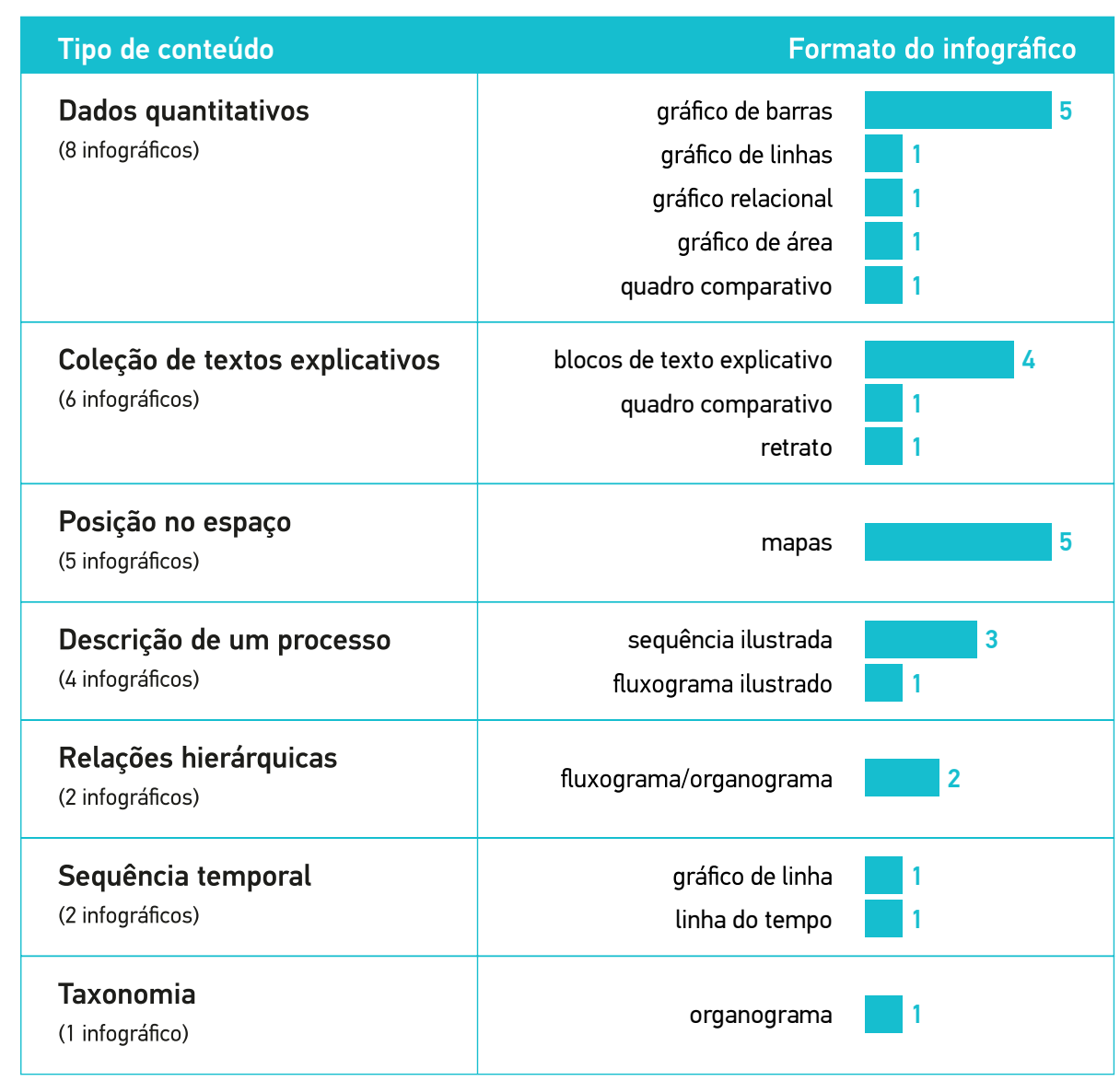

Fonte: Elaboração nossa. 
Ao agruparmos os resultados dos Formulários de Análise por tipo de conteúdo percebe-se maior diferenciação entre as funções infográficas (Figura 52). Na categoria Dados quantitativos, a 'Precisão' é a função prevalente, em virtude da natureza objetiva das representações numéricas. No grupo Descrição de um processo, a 'Utilidade' é bastante eminente em relação às demais funções, refletindo o caráter explanatório das narrativas ilustradas. A única categoria em que a 'Satisfação' demonstra predominância é a das Sequências temporais, devido ao emprego de ilustrações de forma decorativa e ao baixo índice de precisão.

\section{Figura 52. Resultados dos Formulários de Análise agrupados por Tipo de Conteúdo (índices médios)}

$\begin{array}{ll}\text { Dados } & 7,00 \\ \text { quantitativos } & 7,7 \\ \text { (8 infográficos) } & 6,1\end{array}$

\section{Coleção de textos} explicativos

(6 infográficos)

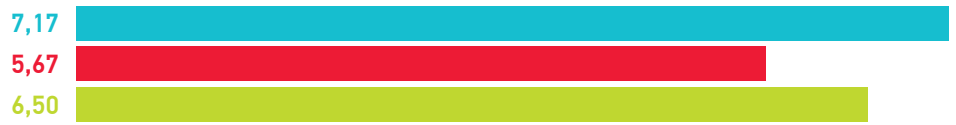

\section{Posição no espaço}

(5 infográficos)

$$
7,00
$$

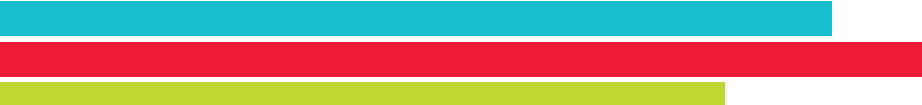

6,50

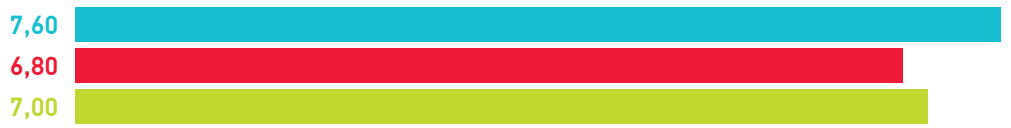

$\begin{array}{ll}\text { Descrição de } & 9,75 \\ \text { um processo } & 7.50 \\ \text { (4 infográficos) } & 6,00\end{array}$

Relações hierárquicas

(2 infográficos)

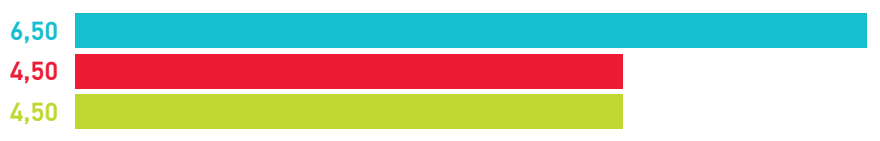

Sequência
temporal
(2 infográficos)

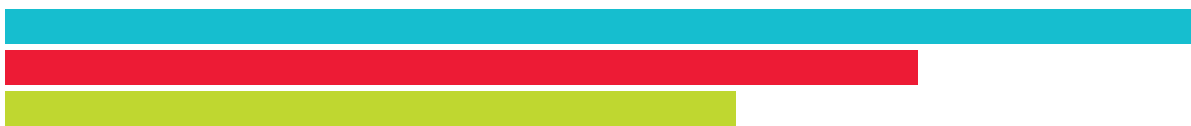

Taxonomia

(1 infográfico)

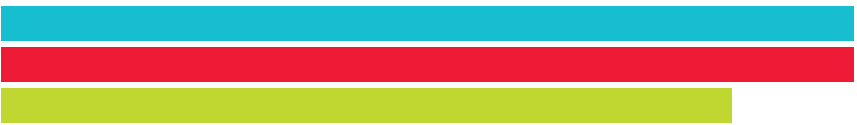


A partir dos levantamentos realizados, foi possível investigar com maior objetividade os princípios de design e relacioná-los a categorias distintas, decorrentes das especificidades do conteúdo textual. Ressaltamos que os produtos dessa metodologia não pretendem ser decisivos ou generalizantes. Mas acreditamos que o modelo em desenvolvimento represente uma contribuição à pesquisa e sistematização da Comunicação e do Design da Informação, na medida em que possibilita visualizar de forma tangível as diferentes funções infográficas e a relevância do emprego de estratégias visuais adequadas às finalidades do produto em questão 
Capítulo 5

CONSIDERAÇÕES FINAIS 


\section{Capítulo 5}

\section{CONSIDERAÇÕES FINAIS}

A riqueza e o privilégio de realizar a presente pesquisa consistiram na incursão por duas áreas distintas, porém com instigantes pontos de intersecção e possibilidades de colaboração mútua. 0 estudo da Divulgação Científica significou a exploração de um campo de premente relevância social, ao passo que o Design da Informação permitiu uma análise que abrangesse tanto a dimensão sintático-semântica (referente à capacidade dos produtos de comunicarem significados com satisfação e conforto estético) quanto a pragmática (concernente à capacidade dos produtos de provocarem reações desejadas nos receptores).

No tocante à revista Pesquisa FAPESP, especificamente, foi possível identificar um predomínio de fotografias em relação aos demais recursos imagéticos. Tal predomínio não surpreendeu por conta da valorização da imagem fotográfica como evidência e documentação para a ciência, além de suas qualidades de atração visual. Já a aparição de infográficos parece corresponder às matérias cujo conteúdo demanda certo grau de didatismo, ou que compreendem volumosas quantidades de dados. 
Com referência às funções mensuradas pela aplicação do protocolo de análise aos infográficos da Pesquisa FAPESP, constatou-se certo equilíbrio, com a maior pontuação média atingida por 'Utilidade', seguida por ‘Precisão' e então por 'Satisfação'. Tal sequência de classificação é vista com otimismo, por convergir com a proposta da Divulgação Científica: 'Utilidade' recebe maior importância na medida em que corresponde ao grau de didatismo do material; 'Precisão' (a despeito de ser relevante devido à natureza dos conteúdos representados) faz-se mais pertinente à Comunicação Científica interpares que à divulgação extrapares; e 'Satisfação', apesar de agregar valor à Divulgação Científica, não é seu foco dominante.

Retomando a indagação inicial quanto à contribuição da infografia para a comunicação entre instituições de pesquisa e sociedade, depreende-se que um projeto infográfico acessível e eficiente alia os princípios da 'Utilidade', 'Precisão' e 'Satisfação', de forma que cada critério atinja uma pontuação satisfatória. É importante frisar, no entanto, que a pontuação máxima para todas as três funções infográficas não é necessariamente o objetivo. Dependendo das especificidades de cada conteúdo informativo, faz-se mais interessante que uma das funções seja prevalente em comparação com as demais.

Ademais, os resultados atingidos e as conclusões aqui aferidas não pretendem ser decisivos ou generalizados para todas as classes de produção infográfica, posto que o presente modelo se propõe a ser uma ferramenta de referência inicial para novas pesquisas que envolvam os temas investigados.

Mas acredita-se que o protocolo em desenvolvimento represente uma contribuição para a pesquisa e a sistematização do Design da Informação, na medida em que possibilita visualizar de forma tangível as diferentes funções infográficas e a relevância do emprego de estratégias visuais adequadas às finalidades de cada produto específico. Além disso, analisar um produto de Divulgação Científica sob a ótica da comunicação representa também uma forma de colaborar para a divulgação eficiente dos avanços da ciência e de suas possíveis aplicações dentre parcelas mais abrangentes da população.

Para finalizar, no que se refere aos desdobramentos futuros para a presente pesquisa, recorremos a Jacobson (2000, p.1), cuja visão acerca do Design da Informação envolve dois conceitos inter-relacionados: edificação e comutatividade. Edificação seria o processo de iluminação pessoal, enquanto comutatividade envolveria troca de informações e mudança coletiva. 0 papel dos designers seria "edificar mais que persuadir, trocar ideias ao invés de forçá-las" (JACOBSON, 2000, 
p.1, tradução nossa), num trabalho colaborativo. Para Campos (2016, p.58), o estabelecimento desse design participatório indicaria uma mudança do design centrado no usuário para o chamado “codesign", prática que toma o usuário como parceiro.

Tal noção reflete o cenário comunicacional contemporâneo, no qual o modelo transmissionista de informação abre espaço para paradigmas dialógicos, atribuindo ao polo receptor um papel mais autônomo e atuante. A ubiquidade dos dispositivos móveis, a interatividade dos aplicativos e a descentralização do emissor da informação conferem às mídias sociais posição privilegiada: "Muito embora sejam conotadas com lazer, o que é fato é que estas são ferramentas importantes no que toca à comunicação organizacional e à divulgação" (MAGALHÃES, 2015, p.57-58).

Nesta conjuntura, as potencialidades do compartilhamento entre usuários se fortalecem, interferindo na circulação e distribuição dos produtos midiáticos. Em A cultura da participação, Shirky (2011) narra a trajetória do que considera-se a primeira “Universidade Invisível": um grupo de cientistas que, no séc. XVII, se comprometeu a divulgar e a compartilhar suas descobertas e métodos de trabalho, em contraposição à postura individualista de seus antecessores. Robert Boyle, membro do grupo e frequentemente considerado o pai da química moderna, ajudou a estabelecer muitas das normas-chave do método científico. Diversos avanços do grupo se deram no âmbito da química, campo até então dominado pelos alquimistas, que trabalhavam sozinhos e sem documentar ou divulgar suas descobertas. Já os membros da Universidade Invisível descreviam seus métodos, postulados e resultados, para que todos pudessem se beneficiar de seus sucessos e fracassos. 0 resultado foi uma das mais importantes transições intelectuais na história da ciência: “A cultura - e não ferramentas ou ideias - animava a Universidade Invisível e transformou a alquimia em química" (SHIRKY, 2011, p.125-126).

A partir desta noção de compartilhamento como ferramenta de comutatividade, apontamos possíveis desdobramentos para a presente pesquisa. Uma investigação futura pode seguir no esquadrinhamento do sincretismo entre quatro objetos prementes: a divulgação da ciência por meio da infografia, num contexto digital que possibilite a interatividade e o compartilhamento. 


\section{REFERÊNCIAS}

AFONSO, Emília da Glória Moreira. A divulgação científica para o grande público: o papel das relações públicas.

0 caso do CIIMAR. (dissertação) Porto: Universidade Fernando Pessoa, 2008.

AGLIOTI, Salvatore; DE SOUZA, Joseph F. X.; GOODALE, Melvyn A. Size-contrast illusions deceive the eye but not the hand. In: Current Biology. v.5, n.6, p.679-685, 1995.

ALBAGLI, Sarita. Divulgação científica: informação científica para a cidadania? In: Revista Ciência da informação. Brasília, v.25, n.3, p.396-404, set./dez., 1996.

ARBACH, Jorge Mtanios Iskandar. O fato gráfico: o humor gráfico como gênero jornalístico. (tese) São Paulo: Universidade de São Paulo, 2007.

ARNHEIM, Rudolf. Visual Thinking. Berkeley: University of California Press, 1969. [345 p.]

AUTHIER-REVUZ, Jacqueline. Palavras incertas: as não coincidências do dizer. Tradução de Claudia Pfeiffer, Gileade Godoi, Luiz Dias, Maria Payer, Mônica Fontana, Pedro Souza, Rosângela Morello, Suzy Rodrigues. Campinas: Editora da Unicamp, 1998.

BARBEIRO, Luís. Introdução. In: Colecção Públicos, n.5, p.9-12, nov. 2007. Disponível em: <http://static.lvengine.net/ setepes/Imgs/Coleccao\%20Publicos\%20-\%20Comunicacao\%20de\%20Ciencia(3).pdf>. Acesso em: 16 jun.2017.

BECPL. Milestones of Science: Galen. s.d. Disponível em: <https://www.buffalolib. org/content/milestones-science/galen>. Acesso em: 24 jun. 2017.

BISWAL, Byomakesh. IBM stores one bit of data on a single atom. In: Computer Business Review. 9 mar. 2017. Disponível em: <www.cbronline.com/news/enterprise-it/storage/ibm-stores-one-bit-of-data-on-a-single-atom>. Acesso em: 14 mar. 2017.

BRAGA, José Luiz. Interação como contexto da Comunicação. In: MATRIZes: Revista do Programa de Pósgraduação em Ciências da Comunicação da Universidade de São Paulo. v.6, n.1, p.25-41, jul./dez.2012.

BRYANT, Chris. Does Australia need a more effective policy of science communication? In: International Journal of Parasitology. v.33, ed.4, p.357-361, 2003.

BUENO, Wilson Costa. Comunicação científica e divulgação científica: aproximações e rupturas conceituais. In: Informação \& Informação. Londrina, v.15, número especial, p. 01-12, 2010.

BUSCATO, Marcela, et al. Fosfoetanolamina sintética: a oferta de um milagre contra o câncer. In: Época. São Carlos, 17 out. 2015. Disponível em: <http://epoca.globo.com/vida/noticia/2015/10/fosfoetanolaminasintetica-oferta-de-um-milagre-contra-o-cancer.html> Acesso em: 10 fev. 2016.

CAIRO, Alberto. Infografía 2.0. Visualización interactiva de información en prensa. Madrid: Alamut, 2008.

The Functional Art: an introduction to information graphics and visualization. Berkeley: New Riders, 2013.

CAMPOS, Ana Paula. Inventório: Processos de design na divulgação científica para crianças: estudo de caso de livro informativo. (dissertação) São Paulo: Universidade de São Paulo, 2016.

CAPRIGLIONE, Laura. Operação torna-se mina de ouro para presidente chileno. In: Folha de S. Paulo. São Paulo, 12 out. 2010. Caderno Mundo.

CARDINALI, Luciano. A tipografia customizada como elemento identitário em sistemas de identidades visuais. (dissertação). São Paulo: Universidade de São Paulo, 2015.

CARDOSO, Rafael. Design para um Mundo Complexo. São Paulo: Cosac Naify, 2012.

CGEE. Percepção pública da Ciência e Tecnologia no Brasil 2015. Brasília: Centro de Gestão e Estudos Estratégicos e Ministério da Ciência, Tecnologia e Inovação, 2015. Disponível em: <http://percepcaocti.cgee.org.br> Acesso em: 31 jan. 2016.

CIUCCARELLI, Paolo. Turning visualisations into stories and 'big pictures'. In: RENDGEN, Sandra; WIEDEMANN, Julius (editor). Information Graphics. Berlin: Taschen, 2012. p.77-95.

CLEVELAND, William S. The Elements of Graphing Data. 2nd ed. Summit: Hobart Press, 1994. [297 p.]

COLACIOPPO, Roberto. Gráfico de Pizza: usar ou não? In: Atirei o pau no gráfico. 2014. Disponível em: <www. atireiopaunografico.com.br/2014/03/grafico-de-pizza-usar-ou-nao.html> Acesso em: 04 fev. 2017.

CORACINI, Maria José Rodrigues Faria. Um fazer persuasivo: o discurso subjetivo da ciência. São Paulo/Campinas: EDUC/Pontes, 1991. [212 p.] 
COSTA, Joan. La Esquemática: visualizar la información. Barcelona: Paidós, 1998. [222p.]

CRICHTON, Michael. Eletronic Life: How to think about Computers. New York: Knopf, 1983.

DE PABLOS, José Manuel. Infoperiodismo. El Periodista como Creador de Infografia. Madrid: Editorial Síntesis, 1999.

DE ROSNAY, Joël. The macroscope: A new world scientific system. New York: Harper \& Row, 1979. [247 p.]

DEACON, Terrence W. The Symbolic Species: the co-evolution of language and the brain. New York: W.W.Norton \& Co., 1998. [528 p.]

DENSITY DESIGN. About. In: DensityDesign. Milano, 2017. Disponível em: <http://

www.densitydesign.org/about>. Acesso em: 2 jun. 2017.

DERVIN, Brenda. Chaos, Order, and Sense-Making: A Proposed Theory for Information Design. In: JACOBSON, Robert (org.). Information Design. Cambridge: The MIT Press, 2000. p.35-57.

DIAS, Maria Ana Peixe; ROSÁRIO, Inês Teixeira do. Lá fora: Guia para descobrir a natureza. Lisboa: Planeta Tangerina, 2014.

DONDIS, Donis A. Sintaxe da Linguagem Visual. Tradução de Jefferson Luiz Camargo. 3a ed. São Paulo: Martins Fontes, 2007.

ENGELKE, Douglas. A cura do Câncer da USP e demais revoluções científicas no jornalismo. In: Conecte: Blog da Sociedade Brasileira de Neurociências e Comportamento. 18 out. 2015. Disponível em: <http://blog.sbnec.org.br/2015/10/a-cura-do-cancer-da-usp-edemais-revolucoes-cientificas-no-jornalismo-os-cientistas-sao-culpados-pelo-sensacionalismo-midiatico> Acesso em: 31 jan. 2016.

ESCOBAR, Herton. Ações por 'pílula do câncer' travam sistema jurídico da USP. In: O Estado de S. Paulo, São Paulo, 13 fev. 2016a. Disponível em: <http://saude.estadao.com.br/noticias/geral,acoes-por-pilulado-cancer-travam-sistema-juridico-da-usp,10000016211> Acesso em: 15 fev. 2016.

Para Inca, parecer científico sobre 'pílula do câncer' é precipitado. In: O Estado de S. Paulo, São Paulo, 13 fev. 2016b. Disponível em: <http://saude.estadao.com.br/noticias/geral,para-inca--parecercientifico-sobre-pilula-do-cancer-e-precipitado,10000016210> Acesso em: 15 fev. 2016.

FAPESP. Relatório de Atividades 2015: versão executiva. São Paulo: FAPESP, 2016. Disponível em: $<$ http://fapesp.br/publicacoes/relat2015_sintese.pdf>. Acesso em: 29 mai. 2017.

Sobre. In: FAPESP. São Paulo, 2017. Disponível em: <http://www.fapesp.br/sobre>. Acesso em: 10 jul. 2017.

FARIAS, Priscila. Editorial. In: InfoDesign - Revista Brasileira de Design da Informação. São Paulo, v.11, n.3, 2014.

FERNANDES, Joana Lobo. Perspectivas sobre os discursos da divulgação da ciência. In: Exedra, Número especial - Comunicação nas Organizações, p.93-106, 2011.

FEW, Stephen. Now you see it: simple visualization techniques for quantitative analysis. Oakland: Analytics, 2009.

Save the Pies for Dessert. In: Visual Business Intelligence Newsletter. 2007. Disponível em: <www.perceptualedge. com/articles/visual_business_intelligence/save_the_pies_for_dessert.pdf> Acesso em: 5 fev. 2017.

FLUSSER, Vilém. O Mundo Codificado: Por uma filosofia do design e da comunicação. Organização: Rafael Cardoso. Tradução de Raquel Abi-Sâmara. São Paulo: Cosac Naify, 2007.

FOSSEY, Marcela Franco. A semântica global em duas revistas de divulgação científica: Pesquisa FAPESP E Superinteressante. (dissertação) Campinas: Universidade Estadual de Campinas, 2006.

FRASCARA, Jorge. ¿Qué es el diseño de información? 1a ed. Buenos Aires: Infinito, 2011.

FRIENDLY, Michael; DENIS, Daniel J. Milestones in the history of thematic cartography, statistical graphics, and data visualization. 2001. Disponível em: <www.datavis.ca/milestones> Accesso em: 30 jan. 2017.

GIANNELLA, Júlia Rabetti. Dispositivo infovis: interfaces entre visualização da informação, infografia e interatividade em sítios jornalísticos. (dissertação) São Paulo: Universidade de São Paulo, 2014.

GOODY, Jack. Watt, lan. The Consequences of Literacy. In: Comparative Studies in Society and History. Cambridge, v.5, n.3, p.304-345, 1963.

GOOGLE, s.d. About. Disponível em: <www.google.com/about> Acesso em: 28 jan. 2017.

HIGOUNET, Charles. História concisa da escrita. Tradução de Marcos Marcionilo. São Paulo: Parábola Editorial, 2003.

HOLMES, Nigel. Nigel Holmes' map of Infographia and idiosyncratic taxonomy. In: RENDGEN, Sandra; WIEDEMANN, Julius (editor). Information Graphics. Berlin: Taschen, 2012.

HORN, Robert E. Information Design: Emergence of a New Profession. In: JACOBSON, Robert (org.). Information Design. Cambridge: The MIT Press, 2000. p.15-33. 
HUFF, Darrell. How to Lie with Statistics. New York: W.W. Norton \& Company, 1954. [144 p.]

IAMARINO, Atila. A ciência brasileira está em crise e a culpa é dos cientistas. 2015a. Disponível em: <http://scienceblogs. com.br/rainha/2015/09/a-ciencia-brasileira-esta-em-crise-e-a-culpa-e-dos-cientistas> Acesso em: 31 jan. 2016.

Ainda bem que estão procurando a Fosfoetanolamina. 2015b. Disponível em: <http://scienceblogs. com.br/rainha/2015/10/fosfoetanolamina-cura-do-cancer> Acesso em: 31 jan. 2016.

IIID. Information Design - Core competencies: What information designers know and can do. Vienna: International Institute for Information Design, 2007. Disponível em: http://www.iiid.net/idx-information-design-core-competencies. Acesso em: 30 abr 2016.

IQSC. Esclarecimentos à Sociedade. São Carlos: Instituto de Química de São Carlos - USP, 2015. Disponível em: <http://www5.iqsc.usp.br/esclarecimentos-a-sociedade> Acesso em: 31 jan. 2016.

ISODA, Gil Tokio de Tani e. Sobre desenho: estudo teórico-visual. (dissertação) São Paulo: Universidade de São Paulo, 2013.

JACOBSON, Robert (org.). Information Design. Cambridge: The MIT Press, 2000.

JAPIASSÚ, Hilton; MARCONDES, Danilo. Dicionário básico de filosofia. 4ª ed. Rio de Janeiro: Jorge Zahar, 2006.

JORNAL DA USP. As relações entre mídia e ciência. In: Jornal da USP. São Paulo: Universidade de São Paulo, 13 mai. 2015. ano 30, n.1092. Disponível em: <http://espaber.uspnet.usp.br/jorusp/?p=41667> Acesso em: 31 jan. 2016.

KANNO, Mario. Infografe: Como e porque usar infográficos para criar visualizações e comunicar de forma imediata e eficiente. São Paulo: Infolide.com, 2013.

KELLY, Kevin. What Technology Wants. New York: Viking, 2010.

KONG, Kenneth. A taxonomy of the discourse relations between words and visual. In: Information Design Journal. v.14, n.3, p.207-230, 2006.

KRAKOVSKY, Marina. The Effort Effect. In: Stanford Magazine. mar./apr. 2007. Cover story. Disponível em: <https://alumni.stanford.edu/get/page/magazine/article/?article_id=32124> Acesso em: 7 fev. 2017.

LAGE, Nilson. Linguagem Jornalística. São Paulo: Ática, 1985. [78 p.]

LAMAS, Susana; ARAÚJO, Sofia Jorge; DIAS, Mónica Bettencourt Dias; COUTINHO, Ana Godinho. Os cientistas como agentes na comunicação de ciência: motivação, formação e iniciativas em Portugal. In: Colecção Públicos, n.5, p.75-85, nov. 2007. Disponível em: <http://static.lvengine.net/setepes/lmgs/ Coleccao\%20Publicos\%20-\%20Comunicacao\%20de\%20Ciencia(3).pdf>. Acesso em: 16 jun.2017.

LAWRENCE, D. H. The power of emotions. In: CARRADA, Giovanni. Communicating science - A scientist's survival kit. Luxembourg: Office for Official Publications of the European Communities, 2006. p.30-31.

LETURIA, Elio. ¿Qué es el infografia? In: Revista Latina de Comunicación Social. La Laguna, v.4, 1998.

LIMA, Ricardo 0. da C. Análise da Infografia Jornalística. (dissertação) Rio de Janeiro: Universidade do Estado do Rio de Janeiro, 2009.

LINCK, Viviane. Fosfoetanolamina e câncer. In: Tem Ciência no teu chá. 2015. Disponível em: <http:// temciencianoteucha.com/2015/10/18/fosfoetanolamina-e-cancer> Acesso em: 31 jan. 2016.

LOPES, Reinaldo José. Dados de remédio anticâncer criado na USP ainda não estão maduros. In: Folha de S.Paulo. São Paulo: 22 out. 2015. Disponível em: <http://www1.folha.uol.com.br/equilibrioesaude/2015/10/1696939-dados-deremedio-anticancer-criado-na-usp-ainda-nao-estao-maduros.shtml?cmpid=comptw> Acesso em: 31 jan. 2016.

LUCAS, Ricardo Jorge de Lucena. Infografia jornalística: uma revisão bibliográfica necessária. In: $X$ CONGRESSO DE ALAIC, 2010. Bogotá. Anais... Bogotá: 2010. Disponível em: <www.rehime.com.ar/escritos/ ponencias/X Congreso de ALAIC - Ponencia Lucena Lucas.pdf> Acesso em: 23 fev. 2017.

LUPTON, Ellen. Writing Lessons: Modern Design Theory. (ensaio) New York: City University of New York, 1988. Disponível em: <www.typotheque.com> Acesso em: 30 abr. 2016.

MACHADO, Arlindo. Pré-cinemas \& pós-cinemas. Campinas: Papirus, 2002.

MACHADO, Irene. Argumentação gráfica na prosa ensaística da revista Pesquisa FAPESP. In: Bakhtiniana: Revista de Estudos do Discurso. São Paulo, v.11, n.2, p.111-136, mai./ago. 2016.

MAEDA, John. The Laws of Simplicity. Design, Technology, Business, Life. Cambridge: The MIT Press, 2006.

MAGALHÃES, Ricardina. A Comunicação Estratégica aplicada à divulgação da Ciência: 0 caso do Centro de Estudos de Comunicação e Sociedade. In: Observatorio Journal - OBS. v.9, n.4, p.51-84, 2015. 
MARCOLIN, Nelson. A Aprovação do Público-alvo. In: Revista Pesquisa Fapesp. São Paulo, ed.190, p.38-41, dez. 2011.

MARTÍN, Eva Domínguez. Interfaces e interactividad: claves para una plástica periodística digital. In: URETA, Ainara Larrondo; TELLERÍA, Ana Serrano (editores). Diseño periodístico en internet. Bilbao: Universidad del País Vasco, 2007.

MARTINS, Eduardo. Manual de Redação e Estilo de O Estado de S. Paulo. 3a ed., revista e ampliada. São Paulo: 0 Estado de S. Paulo, 1997.

MASSIRONI, Manfredo. The Psychology of Graphic Images: Seeing, drawing, communicating. Mahwah: Lawrence Erlbaum, 2002. [319 p.]

MATOS, Ciro Roberto de. Pictogramas e seu uso nas instruções médicas: estudo comparativo entre repertórios para instruções de uso de medicamentos. (dissertação) São Paulo: Universidade de São Paulo, 2009.

MAZUR, Beth. (2003) Information Design in Motion. In: ALBERS, Michael; MAZUR, Beth. Content and Complexity: Information Design in Technical Communication. New York: Routledge, 2013. p.15-38. [380p.]

McCANDLESS, David. The beauty of data visualization (vídeo). TEDGlobal, 2010. Disponível em: <http://www. ted.com/talks/david_mccandless_the_beauty_of_data_visualization> Acesso em: 04 fev. 2016.

What Makes a Good Visualization? 2014. Disponível em: <www.informationisbeautiful.net/ visualizations/what-makes-a-good-data-visualization> Acesso em: 24 jan. 2017.

MEGGS, Philip B. História do Design Gráfico. Tradução de Cid Knipel. São Paulo: Cosac Naify, 2009.

MELLOR, Chris. The future of storage is ATOMIC: IBM boffins stash 1 bit on 1 atom. In: The Register. 9 mar. 2017. Disponível em: <https://www.theregister.co.uk/2017/03/09/ibm_stores_1_bit_on_one_atom>. Acesso em: 14 mar. 2017.

MIJKSENAAR, Paul. Visual function: An introduction to informational design. New York: Princeton Architectural Press, 1997.

MILLAR, Robin. Um currículo de ciências voltado para a compreensão por todos. In: Ensaio: Pesquisa em educação em ciências. Belo Horizonte, v.5, n.2, p. 146-164, out. 2003.

MILLER, George A. The Magical Number Seven, Plus or Minus Two: Some Limits on Our Capacity for Processing Information. In: Psychological Review. v.63, p.81-97, 1956. Disponível em: <http:// www.dominiopublico.gov.br/download/texto/ps000142.pdf> Acesso em: 28 jan. 2017.

MILLER-McCUNE. Tracking Climate Change. Miller-McCune Magazine, 2010.

MOURA, Mariluce. A lenta conquista do espaço na imprensa. In: Revista Pesquisa FAPESP. Experiências em Jornalismo Científico. São Paulo, edição especial, p.2-5, out. 1999.

MOUTINHO, Ana Correia. I\&Deias feitas - entre a ciência e o jornalismo. In: Interacções. Santarém, n.3, p.60-69, 2006.

NASA. Apollo 11 Landing Site. NASA History Program Office, 2012. Disponível em: <https:// www.hq.nasa.gov/alsj/TraverseMapsEarth.html> Acesso em: 08 fev. 2017.

NATHAN, Terrence R. Book review: Photography and Science, by Kelley Wilder. In: Visual Resources: an international journal on images and their uses. London, v.27, n.4, dez. 2011.

NATTERER, Fabian D. et al. Reading and writing single-atom magnets. In: Nature: International weekly jornal of science. 543, p.226-228, 9 mar. 2017. Disponivel em: < www.nature.com/nature/ journal/v543/n7644/full/nature21371.html\#access>. Acesso em: 14 mar. 2017.

NEURATH, Marie; KINROSS, Robin. The transformer: principles of making Isotype charts. Londres: Hyphen Press, 2009.

PÁL, A.; BAKOS, G.A.; TORRES, G.; NOYES, R. W.; LATHAM, D. W.; KOVÁCS, G.; MARCY, G. W.; FISCHER, D. A.; BUTLER, R. P.; SASSELOV, D. D.; SIPOCZ, B.; ESQUERDO, G. A.; KOVÁCS, G.; STEFANIK, R.; LÁZAR, J.; PAPP, I.; SÁRI, P. HAT-P-7b: An Extremely Hot Massive Planet Transiting a Bright Star in the Kepler Field. In: The Astrophysical Journal. v.680, n.2, p.1450-1456, 20 jun. 2008.

PASSINI, Romedi. Sign-Posting Information Design. In: JACOBSON, Robert (org.).

Information Design. Cambridge: The MIT Press, 2000. p.83-98.

PESQUISA FAPESP. Entrevista: Leopoldo de Meis. Ciência com arte e emoção. In: Revista Pesquisa FAPESP. São Paulo, ed.70, p.88-91, nov. 2001.

Quem somos. In: Pesquisa FAPESP. (site) São Paulo, 2017. Disponível em: <http://revistapesquisa.fapesp.br/quem-somos>. Acesso em: 24 mai. 2017.

Um passo próprio da maturidade. In: Revista Pesquisa FAPESP. São Paulo, ed.73, mar. 2002. Editorial, p.5. 
PETTERSSON, Rune. Basic ID concepts: Concepts \&Terms. Vienna: International Institute for Information Design, 2013. Disponível em: <http://www.iiid.net/rune-pettersson-basic-id-concepts>. Acesso em 23 jun. 2017.

Information Design 1: Message Design. Vienna: International Institute for Information Design, 2015. Disponível em: < http://www.iiid.net/rune-pettersson-information-design-1-message-design>. Acesso em 23 jun. 2017.

PIERRO, Bruno de. A ciência vai ao público. In: Revista Pesquisa FAPESP. São Paulo, ed.213, p.32-35, nov. 2013.

PIRULA. A USP, o câncer, e a 'cura' (vídeo). Canal do Pirula, 2015. Disponível em: <https:// www.youtube.com/watch?v=L51NrrK1APQ>. Acesso em: 31 jan. 2016.

PIVETTA, Marcos. A prova final da fosfoetanolamina. In: Revista Pesquisa FAPESP. São Paulo, ed.243, p.16-23, mai. 2016.

PLAZA, Julio. Tradução Intersemiótica. São Paulo: Perspectiva, 2003.

PORTO. Dicionário infopédia de Termos Médicos. Porto: Porto Editora, 2017. Disponível em: <www. infopedia.pt/dicionarios/termos-medicos/macroscopia>. Acesso em: 23 mai. 2017.

RAMACHANDRAN, Vilayanur S. Fantasmas no cérebro: uma investigação dos mistérios da mente humana. Tradução de Antonio Machado. 2a ed. Rio de Janeiro: Record, 2004.

RASKIN, Jef. Presenting Information. In: JACOBSON, Robert (org.). Information Design. Cambridge: The MIT Press, 2000. p.341-348.

RENDGEN, Sandra. Information Graphics. Berlin: Taschen, 2012.

RIBAS, Beatriz. Ser infográfico: apropriações e limites do conceito de infografia no campo do jornalismo. In: III Encontro Nacional de Pesquisadores em Jornalismo, 2005. Florianópolis . Anais... Florianópolis: SBPJor, 2005. Disponível em: <www.facom.ufba.br/jol/pdf/2005_ribas_sbpjor_florianopolis_serinfografico.pdf > Acesso em: 10 abr. 2016.

ROAM, Dan. The Back of the Napkin: Solving problems and selling ideas. London: Portfolio, 2008.

ROBBINS, Naomi B. Creating More Effective Graphs. Hoboken: Wiley-Interscience, 2005. [402 p.]

SAENGER, Paul. A separação entre palavras e a fisiologia da leitura. In: OLSON, David R.; TORRANCE, Nancy. Cultura escrita e oralidade. Tradução de Valter Lellis Siqueira. São Paulo: Ática, 1995. p.211-228. [286 p.]

SALAVERRÍA, Ramón; SANCHO, Francisco. Del papel a La Web. Evolución y claves del diseño periodístico en internet. In: URETA, Ainara Larrondo; TELLERÍA, Ana Serrano (editores). Diseño periodístico en internet. Bilbao: Universidad del País Vasco, 2007.

SANCHO, José Luis Valero. La Infografia: técnicas, análisis y usos periodísticos. Barcelona: Universitat Autònoma de Barcelona, 2001.

SATOMI. Cornetada no Gráfico! In: Atirei o pau no gráfico. 2010. Disponível em: <http://www. atireiopaunografico.com.br/search?q=lie+factor> Acesso em: 06 fev. 2017.

SAUTOY, Marcus du. The Beauty of Diagrams - Episode 4: Florence Nightingale. (série de televisão) WATERHOUSE, Michael (prod.); CLARKE, Steven (dir.). London: BBC, 2010.

SBDI - Sociedade Brasileira de Design da Informação. Sobre. s.d. Disponível em: <http://sbdi.inlabmidia.com/sobre> Acesso em: 23 fev. 2017.

SCHUDSON, Michael. The power of news. Cambridge: Harvard University Press, 1996.

SERVICE, Robert. DNA could store all of the world's data in one room. In: Science. Technology, 2 mar. 2017. Disponível em< http://www.sciencemag.org/news/2017/03/dna-could-store-all-worlds-data-one-room>. Acesso em: 14 mar. 2017.

SHANKAR, P Ravi. Gapminder: Understanding Health through Interactive Statistics. In: Education in Medicine Journal. Penang, v.7, n.2, p.76-77, jun. 2015.

SHIRKY, Clay. A cultura da participação: criatividade e generosidade no mundo conectado. Tradução de Celina Portocarrero. Rio de Janeiro: Zahar, 2011.

SILVA, Adriano. Quem lâ a SUPER? In: Superinteressante. São Paulo, 31 out. 2016. Disponível em: <http://super.abril.com.br/historia/quem-le-a-super>. Acesso em: 21 jun. 2017.

SILVEIRA, Luciana H.Y. Modelo de caracterização de infográficos. Uma proposta para análise e aplicação jornalística. (dissertação) São Paulo: Universidade de São Paulo, 2010.

SIMÕES, Davi. Cura do Câncer na USP e Divulgação Científica (vídeo). In: Canal Primata Falante. 2015. Disponivel em: <https://www.youtube.com/watch?v=nXN3KG_AIR8> Acesso em: 31 jan. 2016. 
SIMONS, Gary F.; FENNIG, Charles D. (editores). Ethnologue: Languages of the World. 20th ed. Dallas: SIL International, 2017. Disponível em: <www.ethnologue.com> Acesso em: 23 fev. 2017.

SOJO, Carlos Abreu. ¿Es la infografía un género periodístico? In: Revista Latina de Comunicación Social. La Laguna, v.51, 2002. Disponível em: <www.ull.es/publicaciones/latina/2002abreujunio5101.htm> Acesso em: 10 abr. 2016.

SOUZA, Sandra. Pictogramas brasileiros. Um panorama de nosso jeito de designhar conceitos. (tese de livre-docência) São Paulo: Universidade de São Paulo, 2010.

SOUZA, Sandra M. R. de; SCHMID, Maria Regina L. 0 tratamento da informação no design de catálogos técnicos impressos. In: InfoDesign - Revista Brasileira de Design da Informação. v.6, n.3, p.12-23, 2009.

STIFF, Paul. In: ZWAGA, Harm.J.G.; BOERSEMA, Theo; HOONHOUT, Henriëtte, C.M. (eds.) Visual Information for Everyday Use: Design and Research Perspectives. Taylor \& Francis, 1999. [328p.]

STONE, M. Florence Nightingale. In: HEYDE,C.C.; SENETA,E. (eds.). Statisticians of the Centuries. New York: Springer-Verlag, 2001. p.171-175.

TEIXEIRA, Tattiana. Infografia e Jornalismo: conceitos, análises e perspectivas. Salvador: EDUFBA, 2010. [120p.]

TESSLER, Leandro R. Fosfoetanolamina: 0 Cogumelo do Sol da USP. In: Cultura Científica. 2015. Disponível em: <http:// ccientifica.blogspot.com.br/2015/10/fosfoetanolamina-o-cogumelo-do-sol-da.html> Acesso em: 31 jan. 2016.

THOMPSON, Clive. Why We Should Learn the Language of Data. In: Wired US. abr. 2010. Disponivel em: <https://www.wired.com/2010/04/st_thompson_statistics> Acesso em: 14 fev. 2017.

TROTTA, Tatiana; SPINILLO, Carla Galvão. Ilustração Científica: A informação construída pela sintaxe visual. In: InfoDesign - Revista Brasileira de Design da Informação. v.13, n.3, p.261-276, 2016.

TUFFANI, Maurício. 0 fogo cruzado do jornalismo de ciência. In: Com Ciência. Revista eletrônica de jornalismo científico. Campinas, n.45, jul. 2003.

TUFTE, Edward R. The Visual Display of Quantitative Information. 2nd ed. Cheshire: Graphic Press, 2007.

Envisioning Information. Cheshire: Graphic Press, 1998.

USP. Os fatos sobre a fosfoetanolamina. São Paulo: Universidade de São Paulo, 2015. Disponível em: <http://www5. usp.br/99485/usp-divulga-comunicado-sobre-a-substancia-fosfoetanolamina> Acesso em: 31 jan. 2016.

VARELLA, Drauzio. Esclarecimentos sobre a fosfoetanolamina (vídeo). 2015. Disponível em: <https://www.youtube.com/watch?v=09d0i65pKMQ> Acesso em: 31 jan. 2016.

VIGNELLI, Massimo. The Vignelli Canon. Nova York: 2009. Disponível em: <www.vignelli.com/canon.pdf> Acesso em: 8 fev. 2017.

VILICIC, Filipe; GODOY, Marcelo. Polícia já estuda criação de um 'batalhão do ruído'. In: 0

Estado de S. Paulo. São Paulo, 20 jun. 2010. Cidades, Caderno C3, p.39.

VOGT, Carlos (org.). Cultura científica: desafios. São Paulo: Edusp, 2006. [231 p.]

WALLER, Rob. (1996) The origins of the Information Design Association. University of Reading, 2008.

Disponível em: <http://www.robwaller.org/IDA_origins_RW.pdf>. Acesso em: 15 mar. 2016.

WARE, Colin. Information visualization: design for perception. San Diego: Academic Press, 2000.

WILDBUR, P; BURKE, M. Information graphics: Innovative Solutions in Contemporary Design. London: Thames and Hudson, 1998.

WINKLER, Dietmar. Hasta el hombre de las cavernas podría hacerlo mejor. In: FRASCARA, Jorge. ¿Qué es el diseño de información? 1 a ed. Buenos Aires: Infinito, 2011. p.57-64.

WONG, Dona M. The Wall Street Journal Guide to Information Graphics: The Dos and Don'ts of Presenting Data, Facts, and Figures. New York: W.W. Norton \& Company, 2010. [157 p.]

WURMAN, Richard Saul. Ansiedade de Informação. Como transformar informação em compreensão. Tradução de Virgílio Freire. São Paulo: Cultura Editores Associados, 1991.

How I strive to understand what it is like not to understand. In: RENDGEN, Sandra; WIEDEMANN, Julius (editor). Information Graphics. Berlin: Taschen, 2012. p.37-56.

ZAMBONI, Lilian Márcia Simões. Cientistas, jornalistas e a divulgação científica: subjetividade e heterogeneidade no discurso da divulgação científica. Campinas: Editora Autores Associados, 2001. [167 p.]

ZOLNERKEVIC, Igor. Nas redondezas de outros mundos. In: Revista Pesquisa Fapesp. São Paulo, ed.191, p.24-27, jan. 2012. 
APÊNDICE 
APÊNDICE A. Levantamento dos recursos gráficos (ed.234)

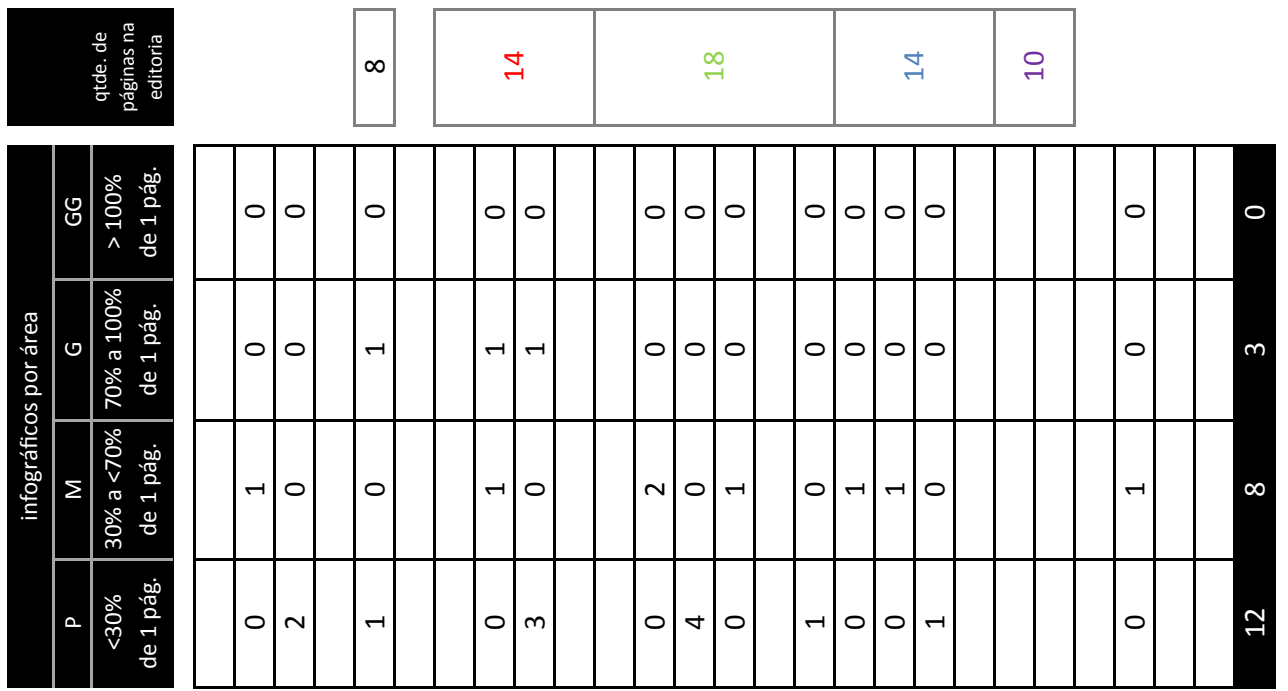

离

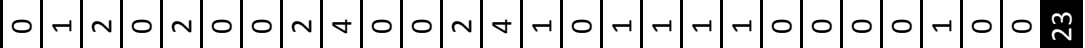

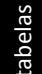

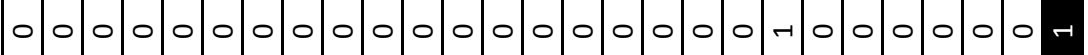

总

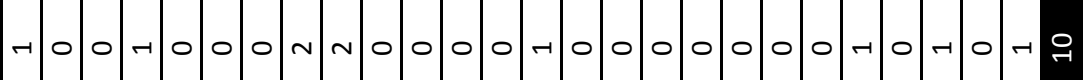

荾

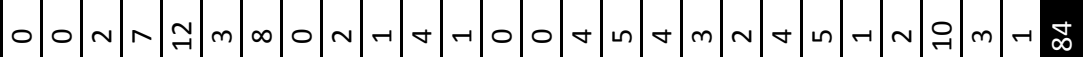

产

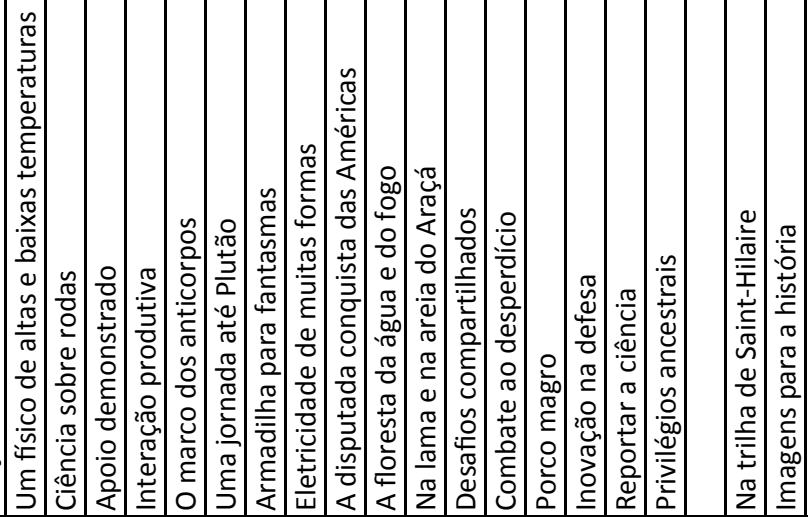

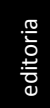

$-1$

$\because \frac{\pi}{\circ} \div$

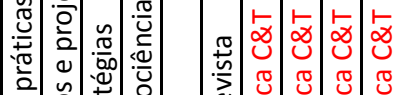

웛

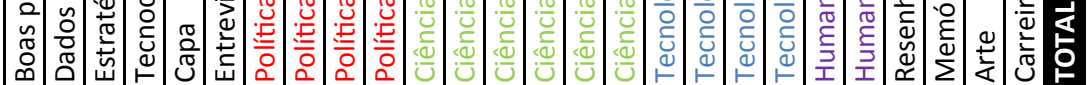


APÊNDICE A. Levantamento dos recursos gráficos (ed.235)

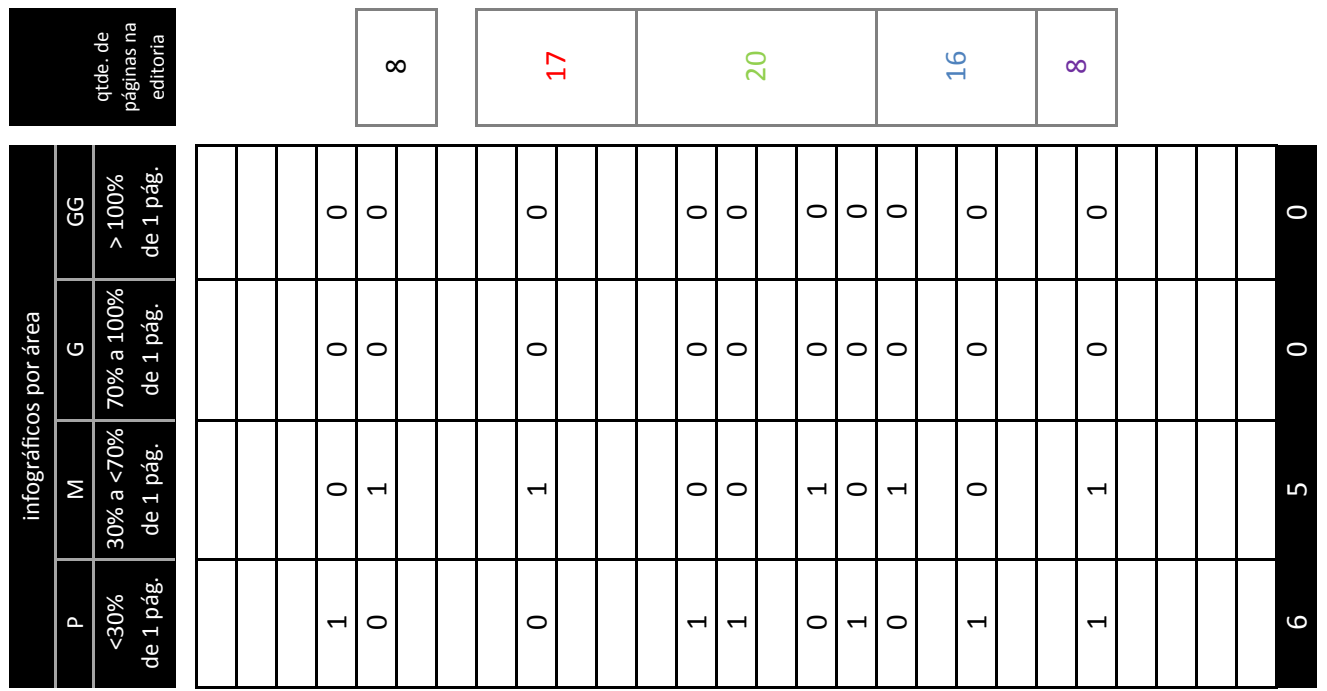

离

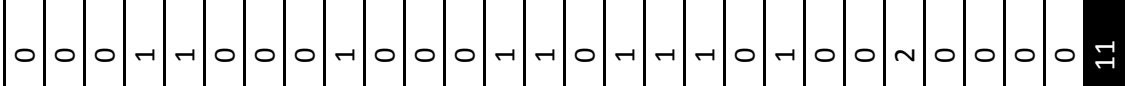

$\frac{\frac{\mathscr{0}}{\mathbb{g}}}{\mathrm{g}}$

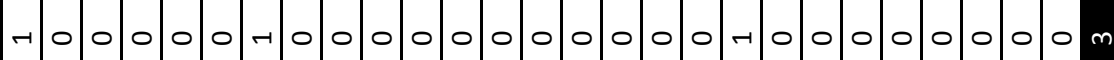

总

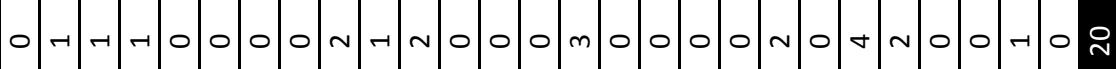

总

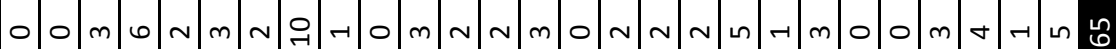

产

(1)

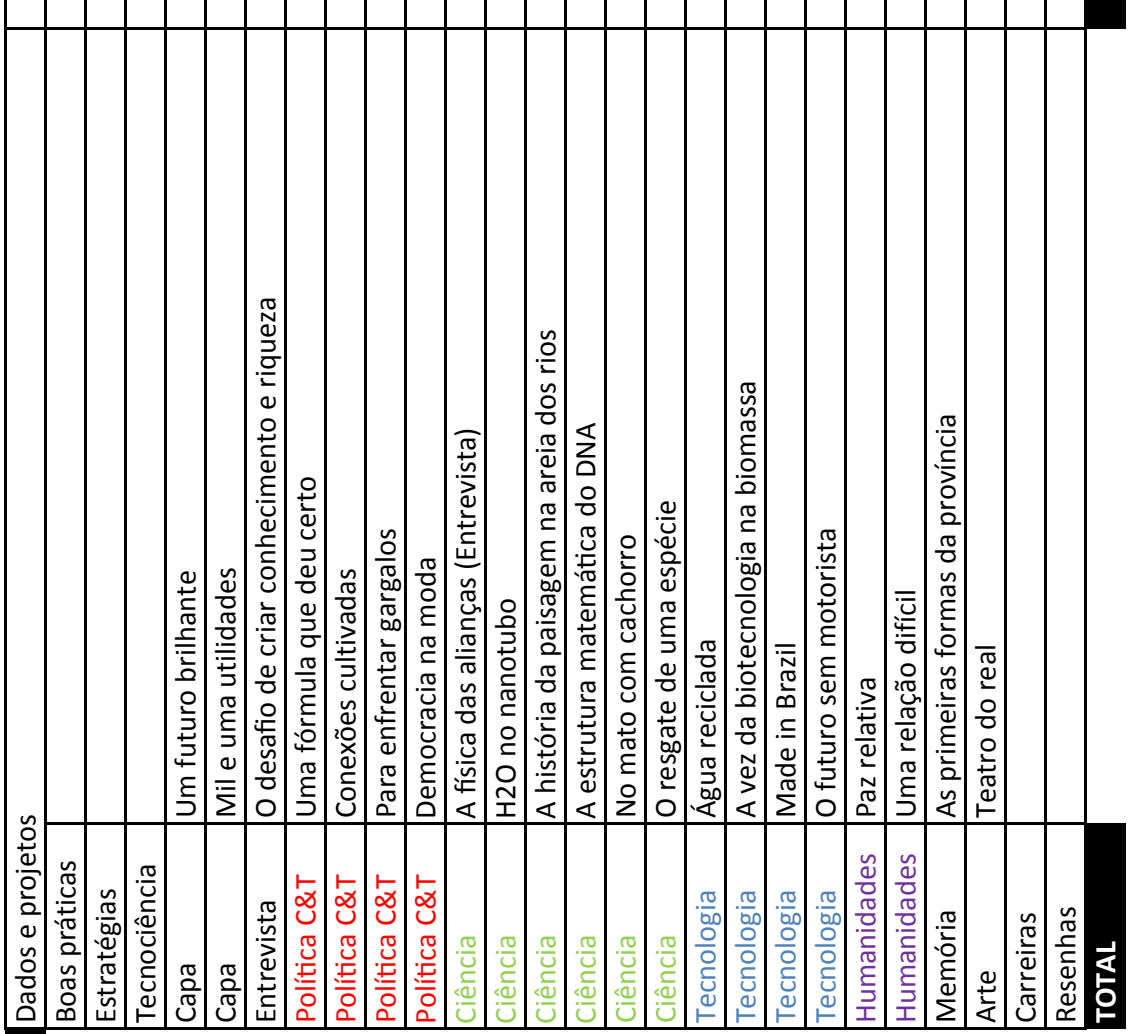

这

$\stackrel{m}{\approx}$

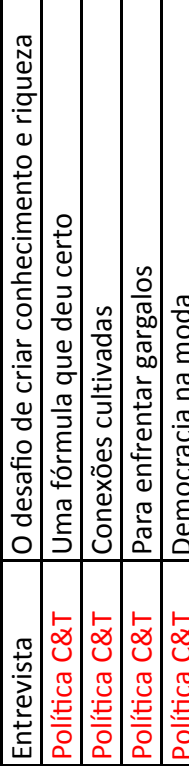


APÊNDICE A. Levantamento dos recursos gráficos (ed.236)

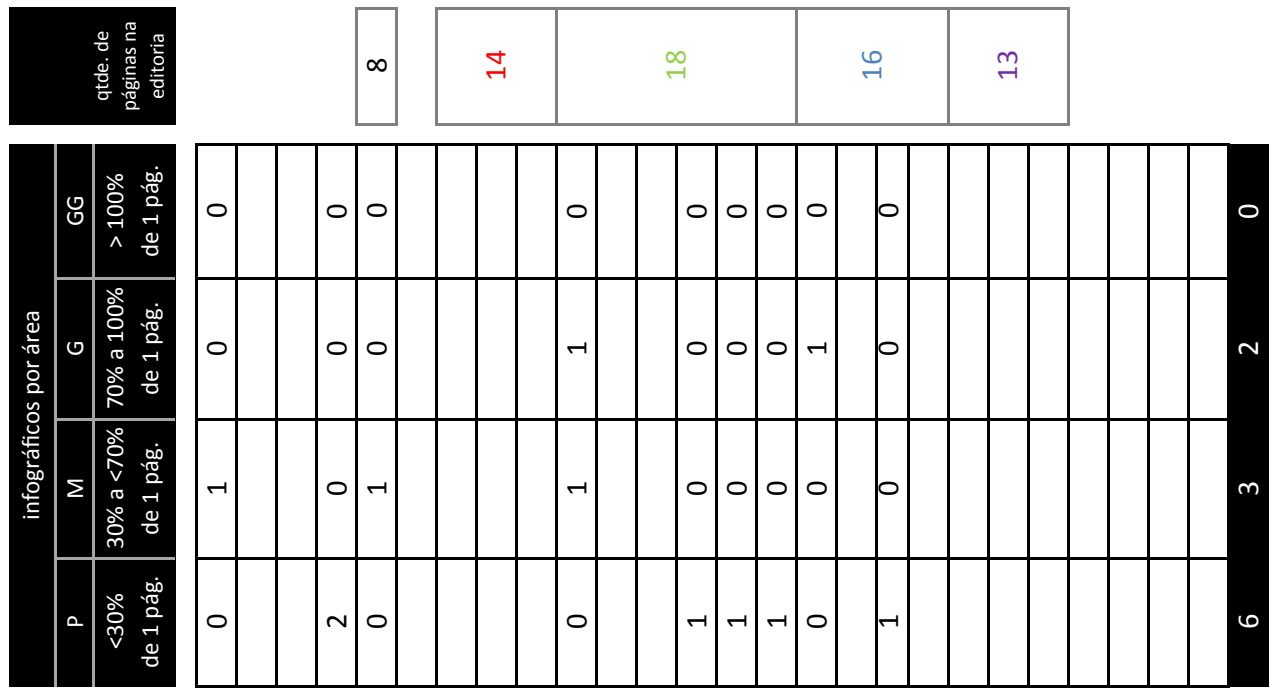

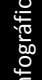

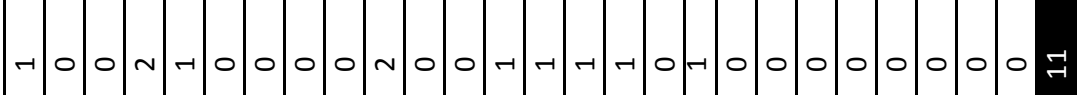

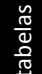

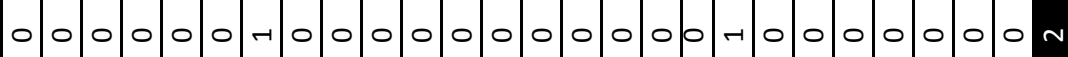

总

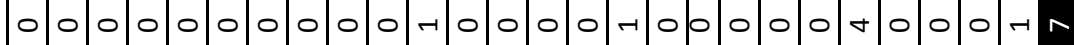

$\stackrel{\circ}{\circ}$

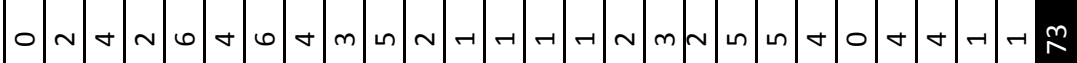

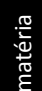

\begin{tabular}{|l|l|l|l|l|l|l|l|l|l|l|l|l|l|l|l} 
& & & & & & & & & & & & & \\
\hline
\end{tabular}

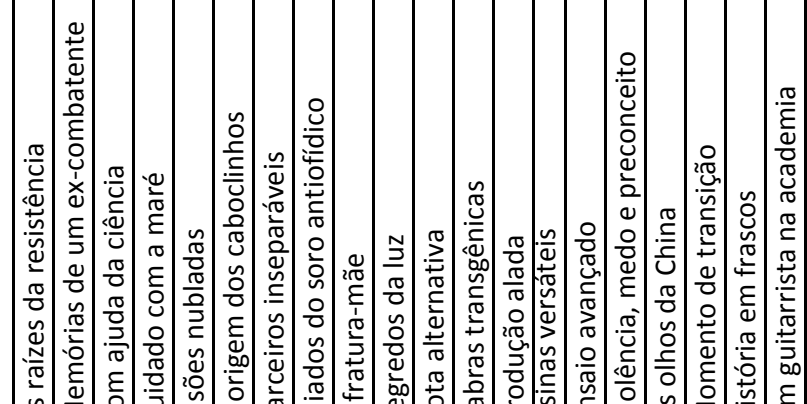

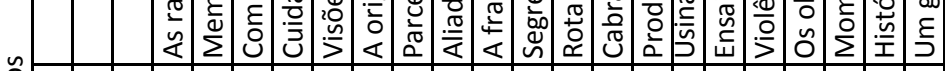


APÊNDICE A. Levantamento dos recursos gráficos (ed.237)

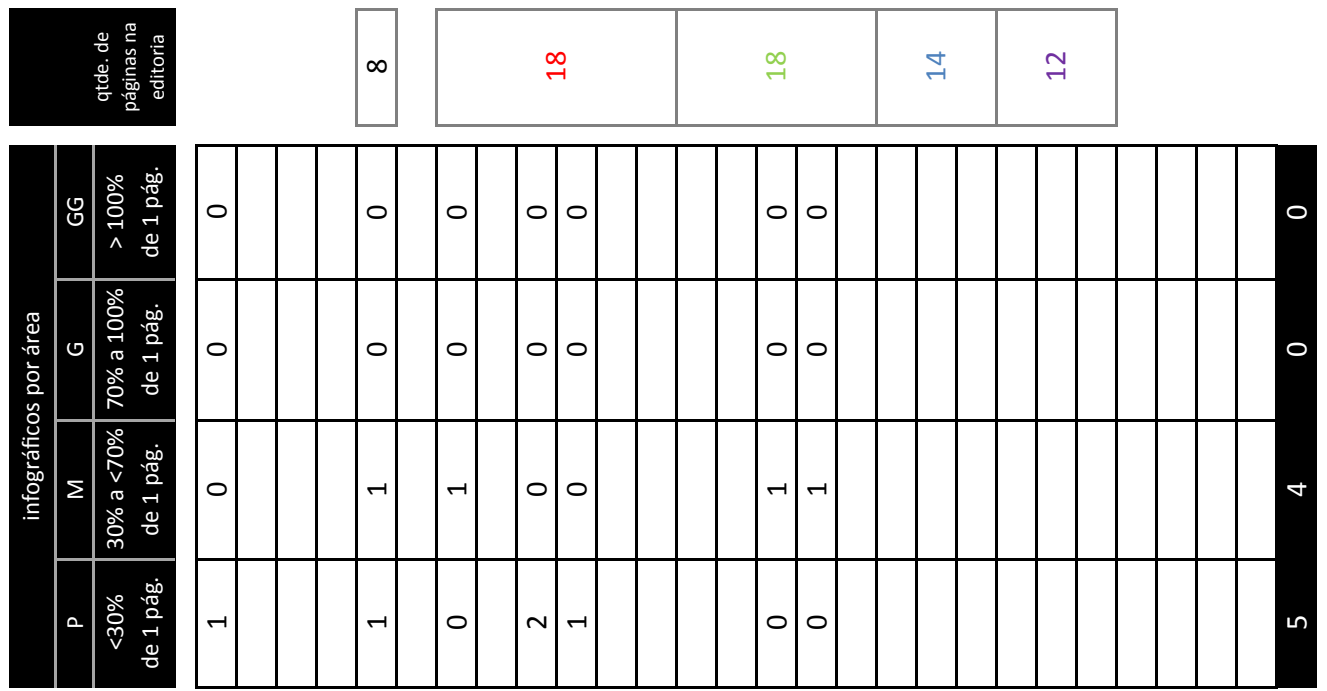

离

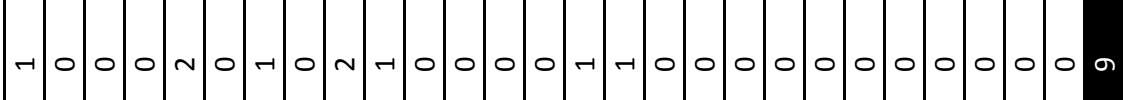

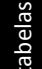

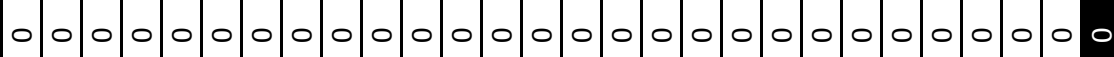

总

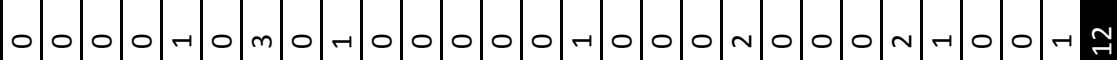

总

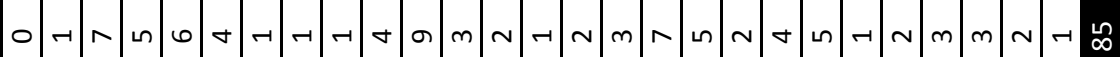

产

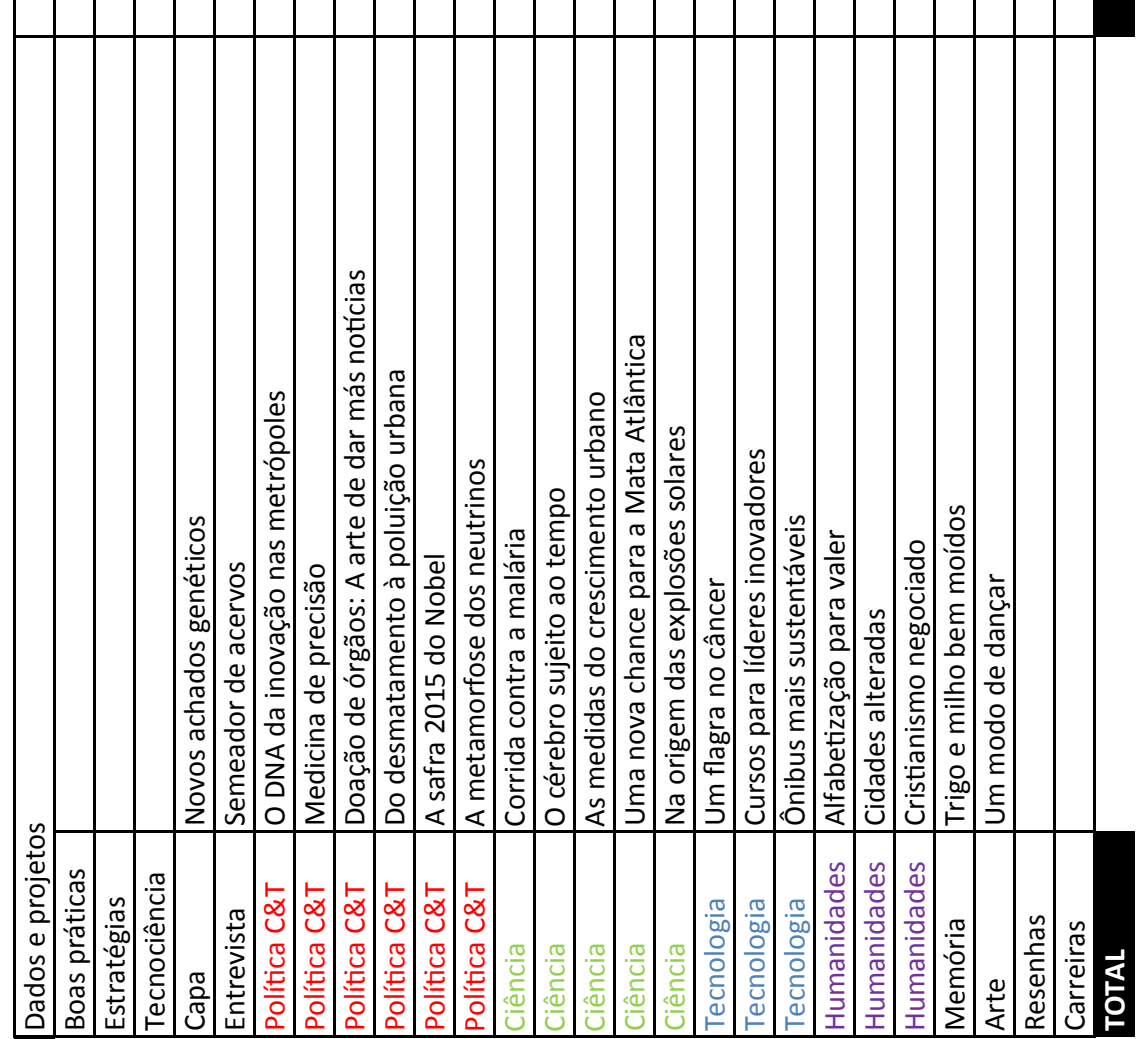

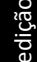

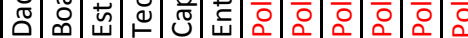


APÊNDICE A. Levantamento dos recursos gráficos (ed.238)

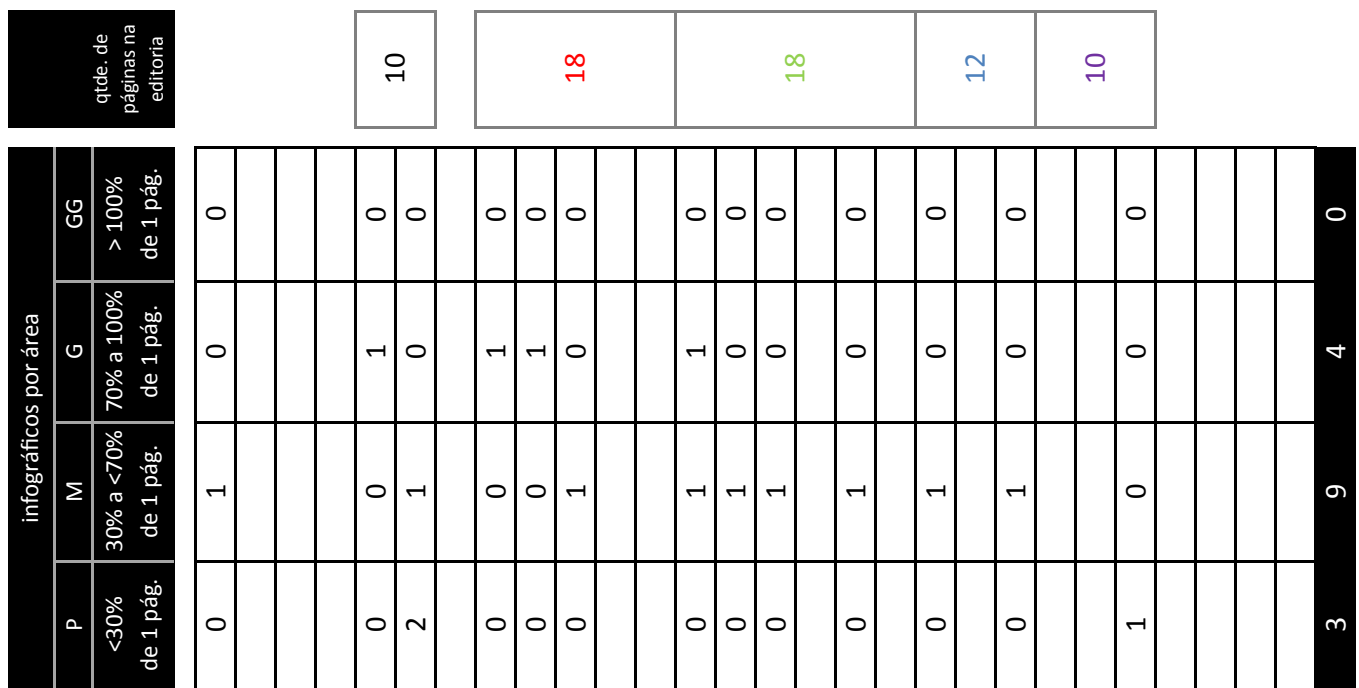

象

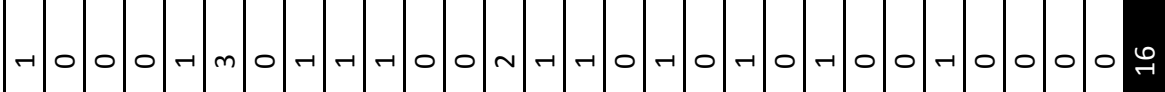

$\frac{\mathscr{0}}{\mathbb{D}}$

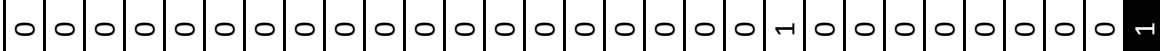

总

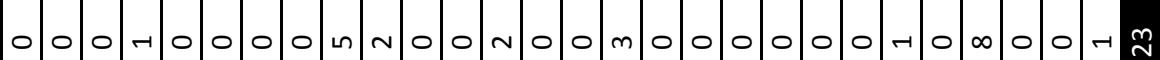

$\stackrel{\circ}{\circ}$

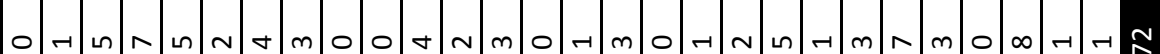

:

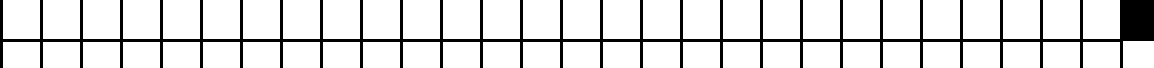

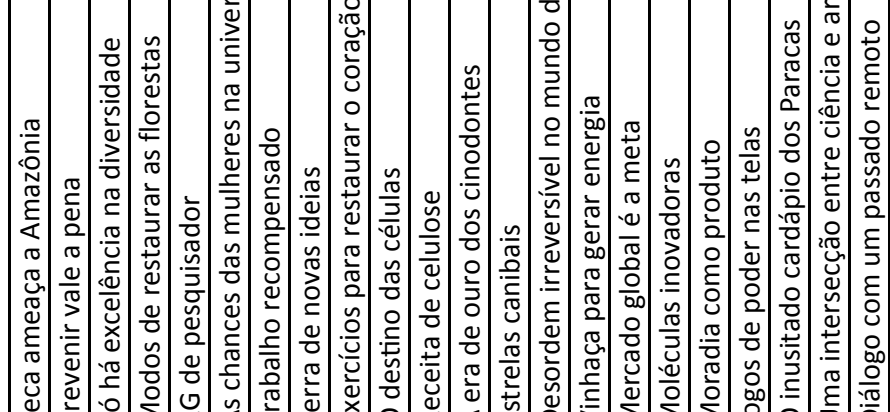

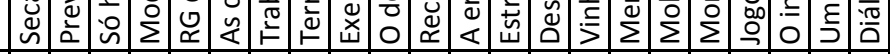

爱

$\frac{0}{0}$

递

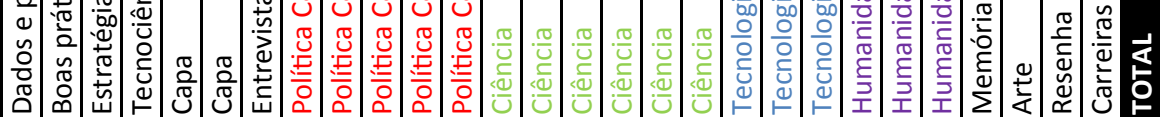


APÊNDICE A. Levantamento dos recursos gráficos (ed.239)

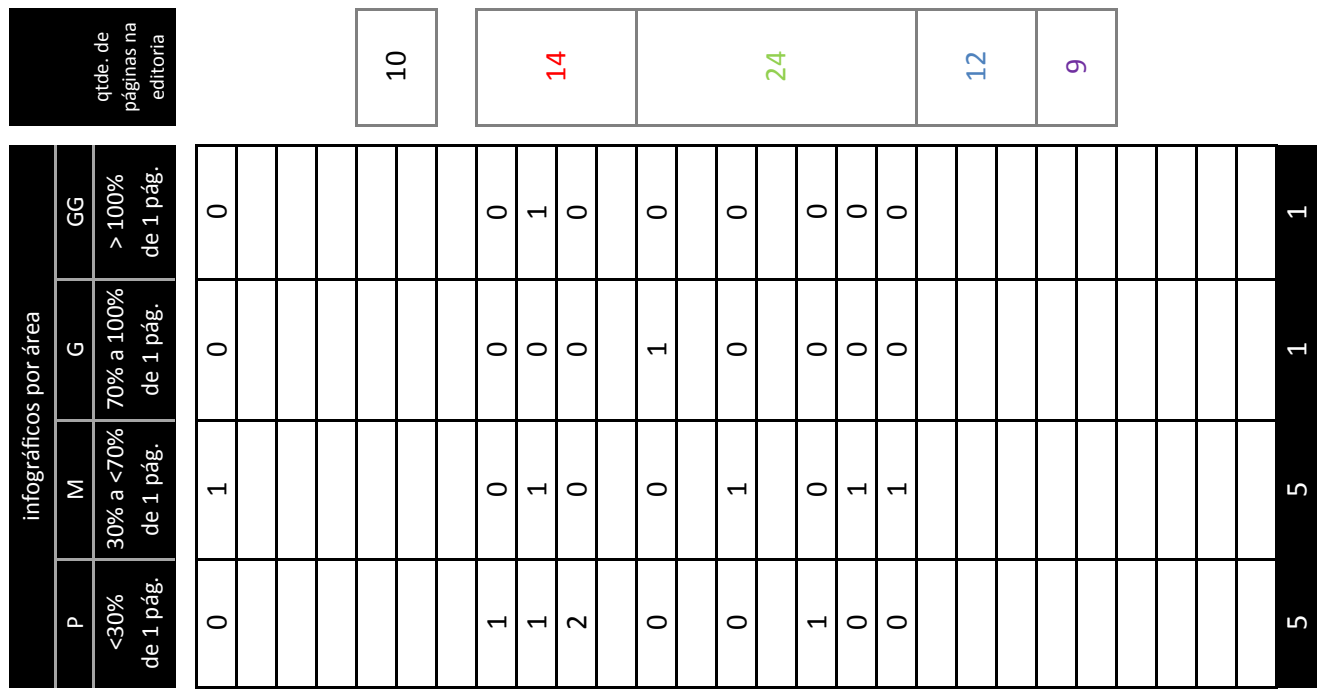

离

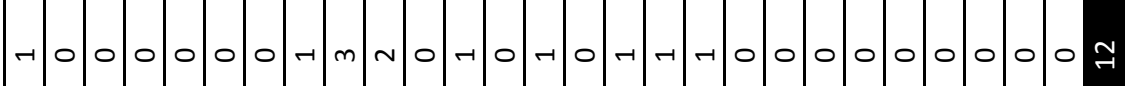

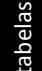

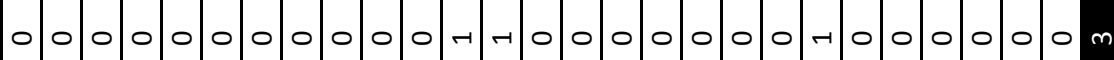

总

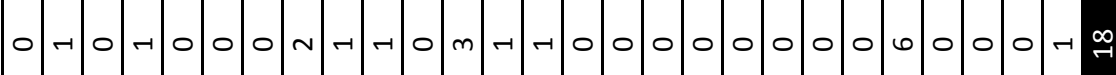

$\stackrel{\circ}{\circ}$

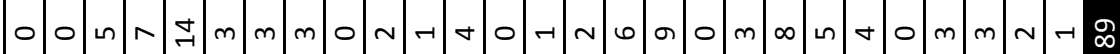

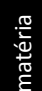

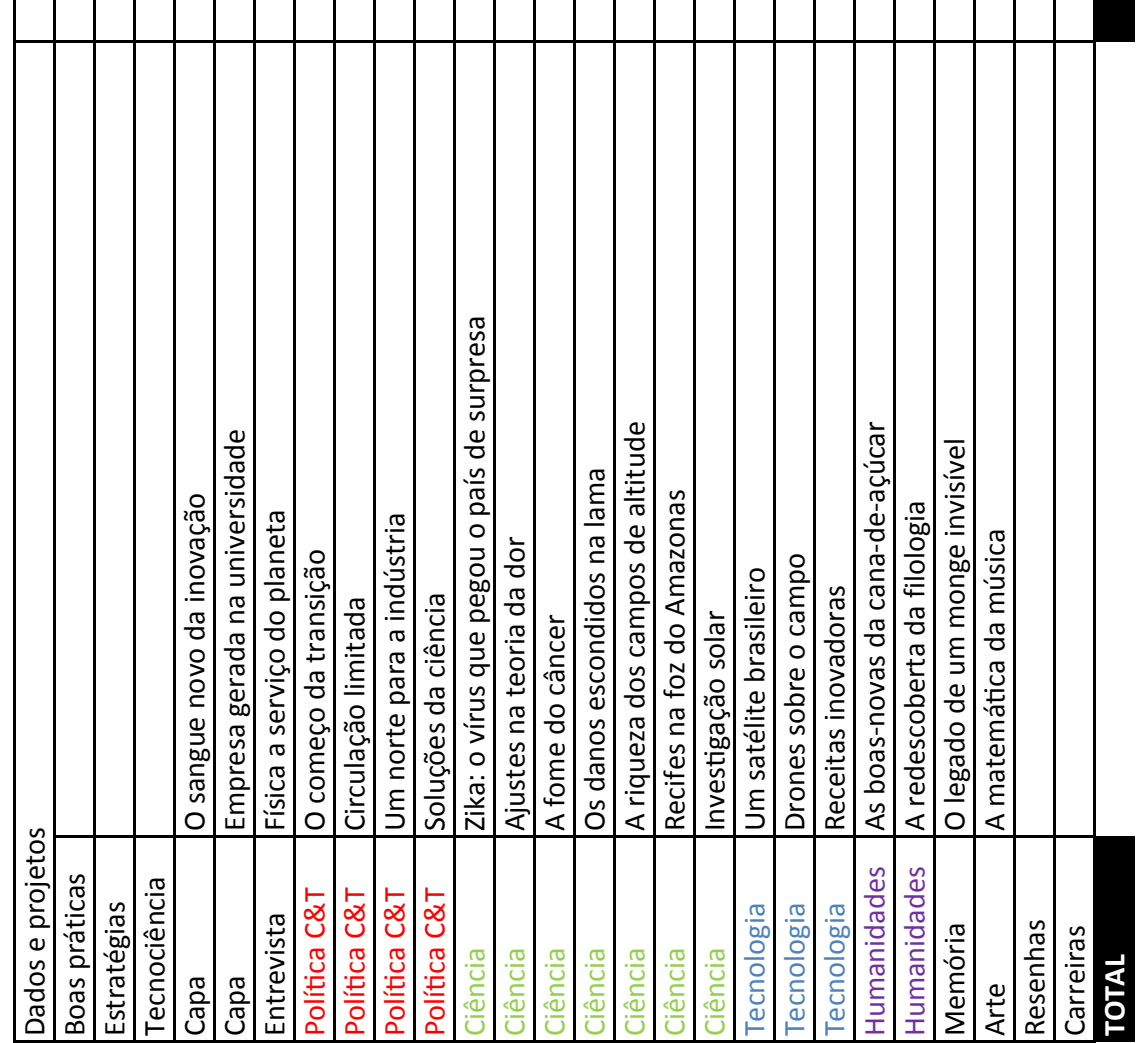

임

\% 
APÊNDICE A. Levantamento dos recursos gráficos (ed.240)

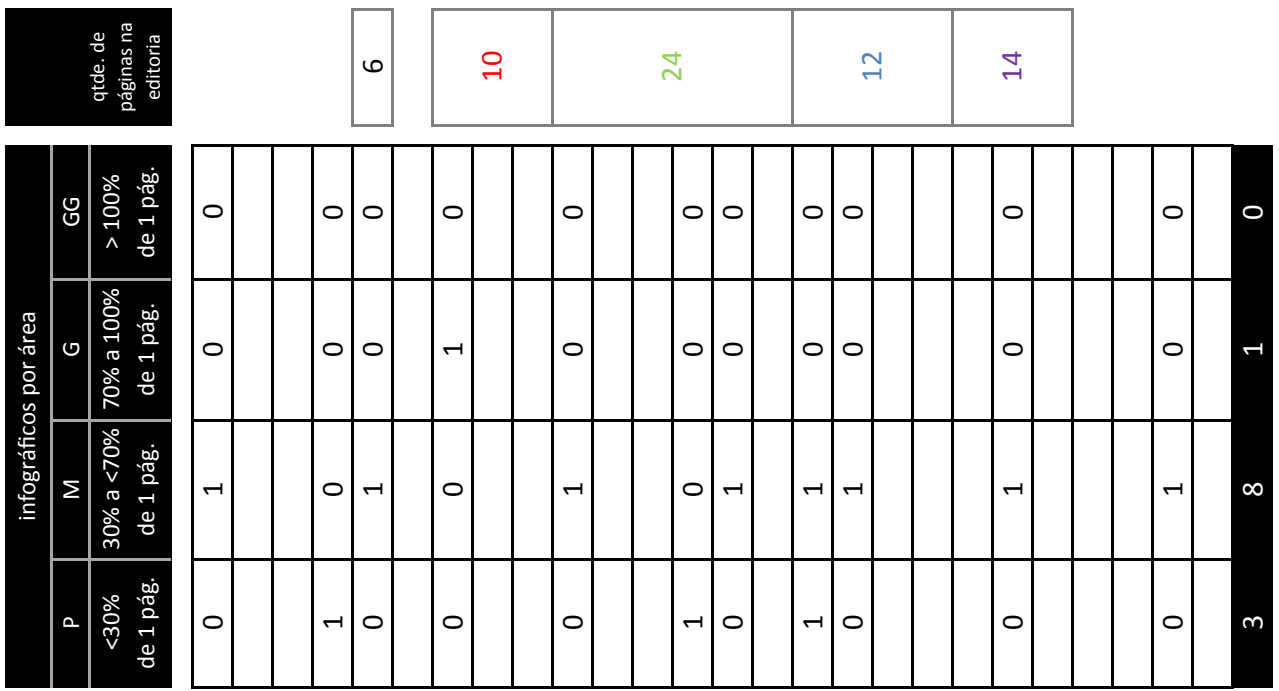

离

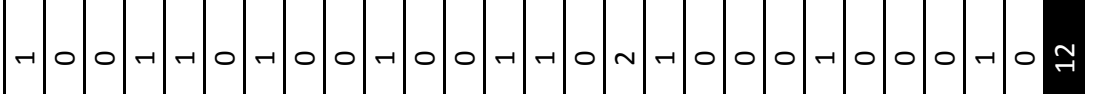

$\frac{\frac{2}{6}}{\frac{6}{g}}$

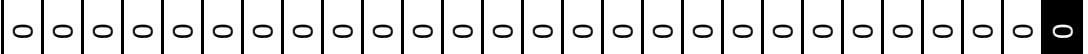

总

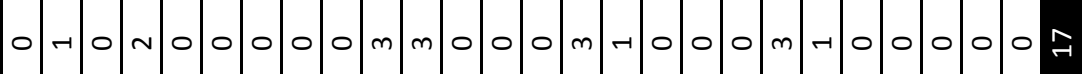

荾

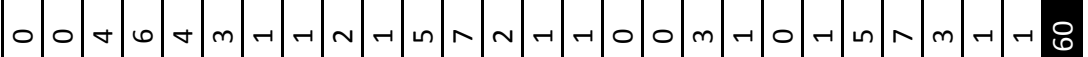

爱

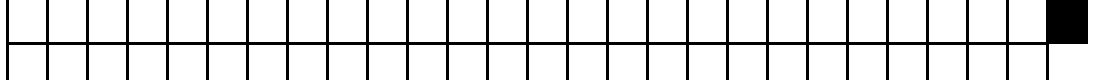

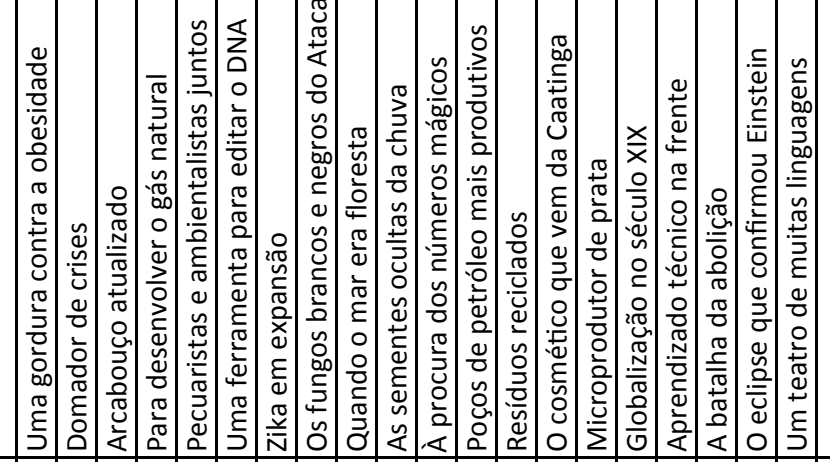

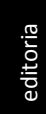

兽

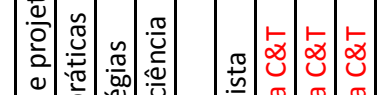

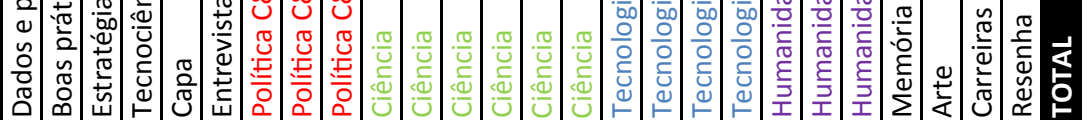

要

원 
APÊNDICE A. Levantamento dos recursos gráficos (ed.241)

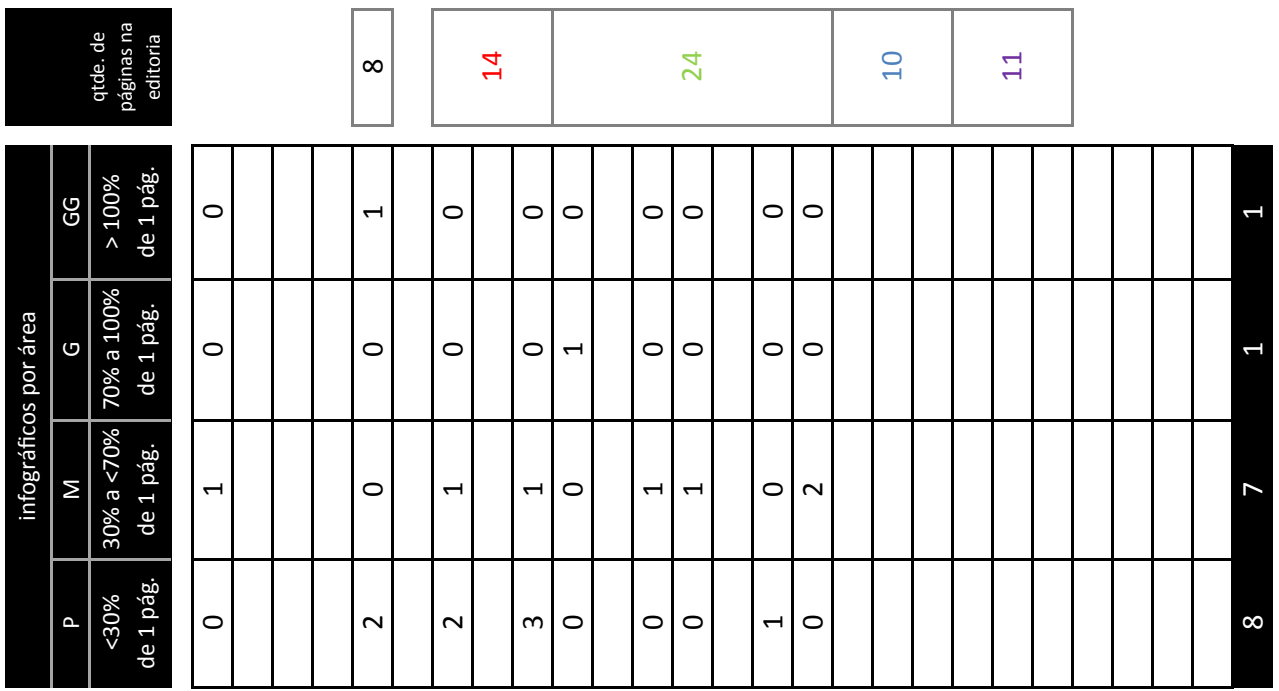

离

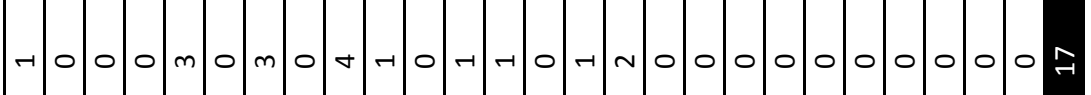

$\frac{\frac{2}{6}}{\frac{6}{g}}$

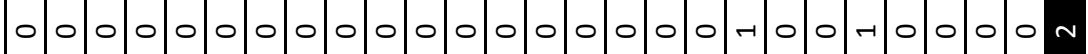

总

兽

$\stackrel{\circ}{\circ}$

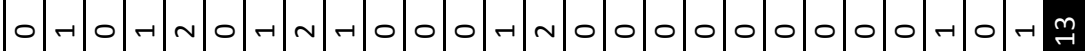

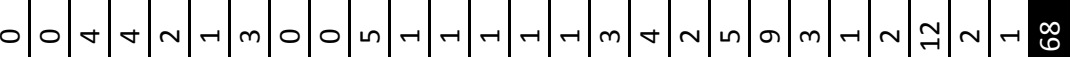

产:

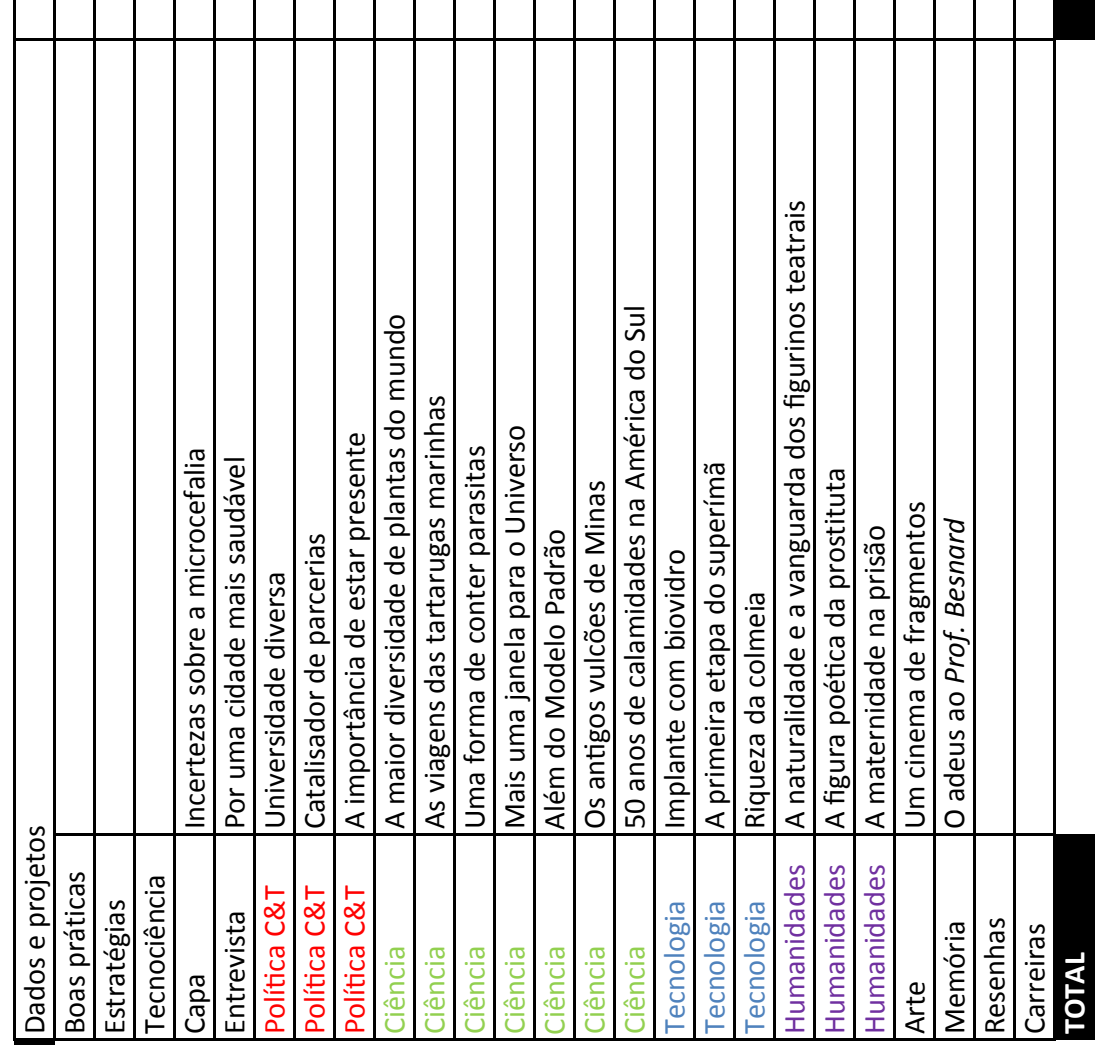

웜

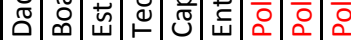


APÊNDICE A. Levantamento dos recursos gráficos (ed.242)

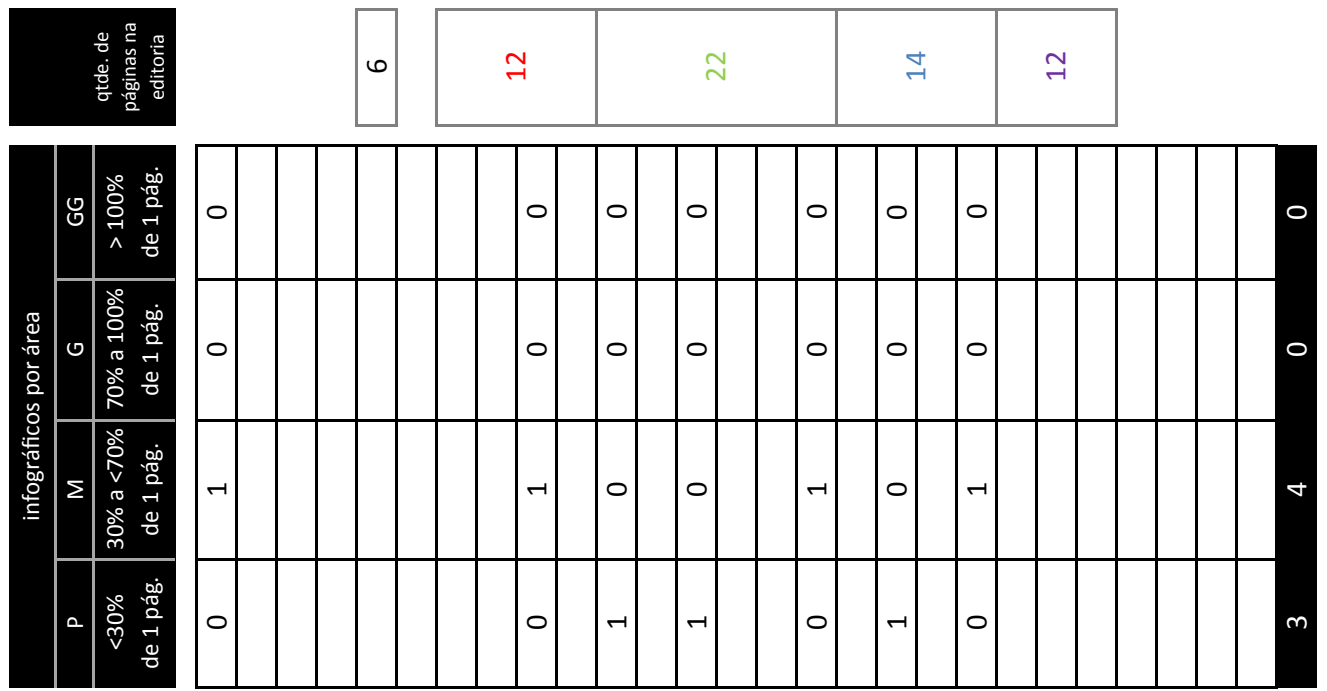

离

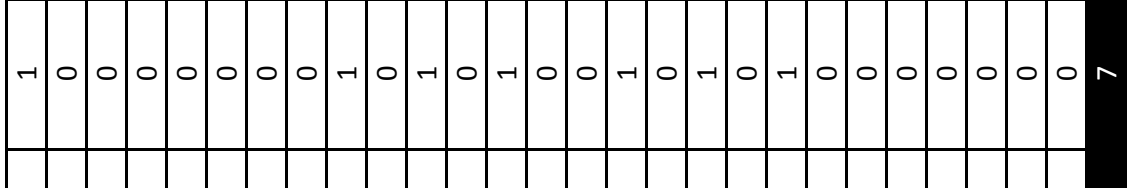

$\frac{\sqrt{2}}{\frac{8}{8}}$

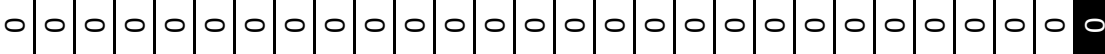

总

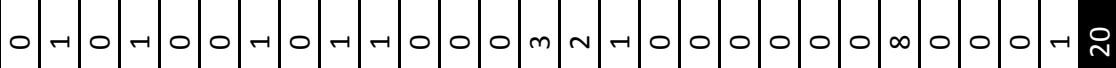

总

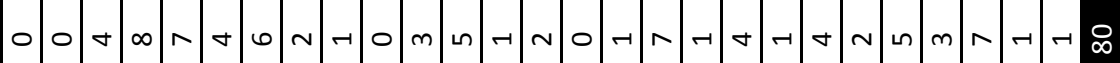

产

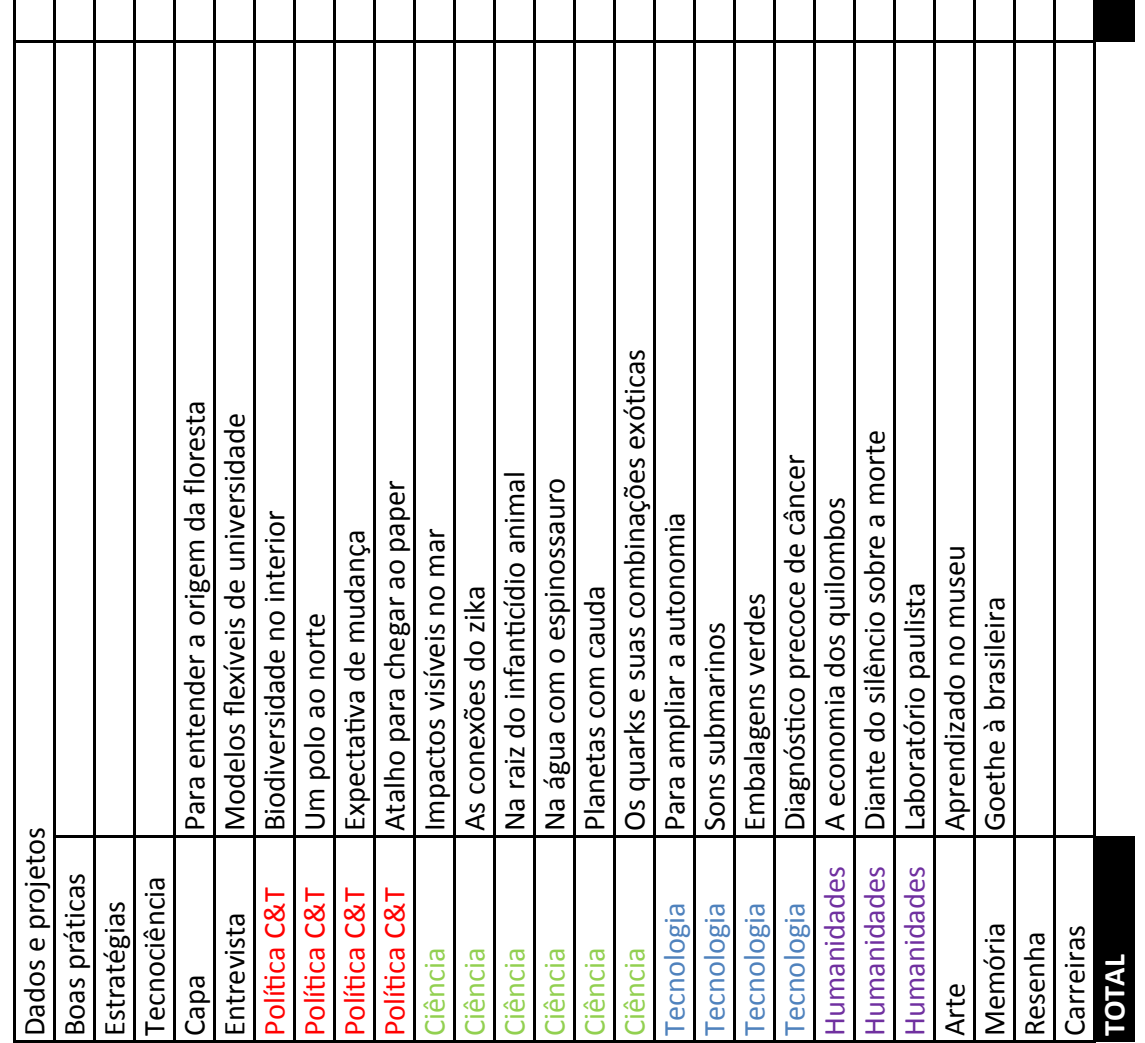

递

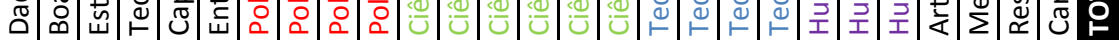


APÊNDICE A. Levantamento dos recursos gráficos (ed.243)

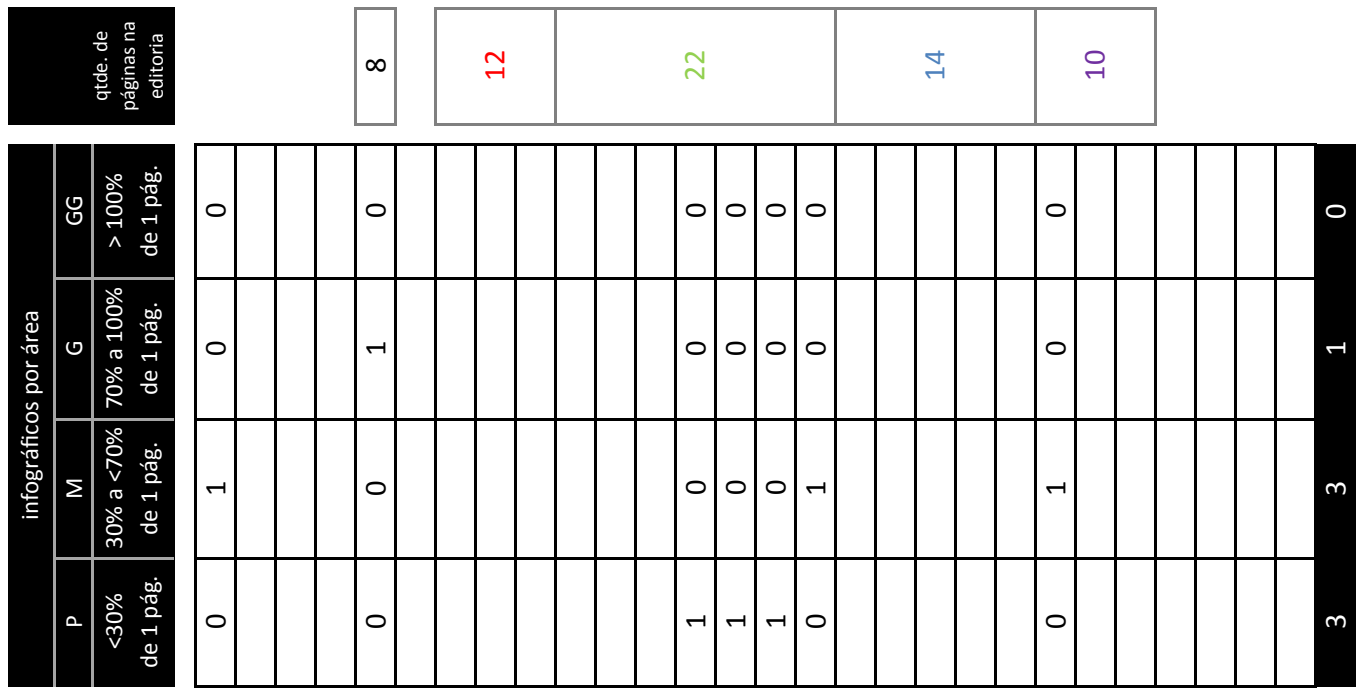

离

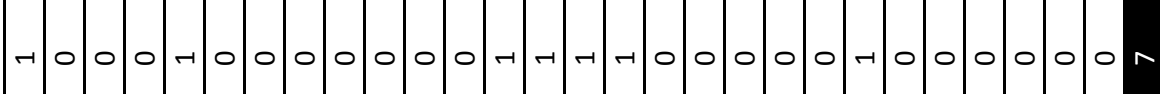

$\frac{\mathscr{0}}{\mathbb{D}}$

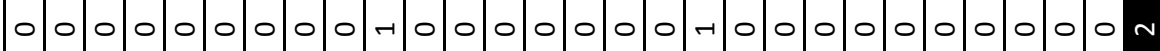

总

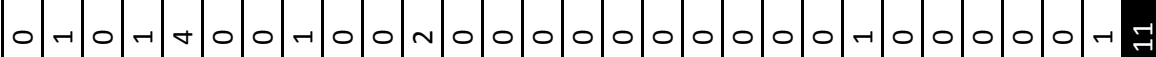

$\stackrel{\circ}{\circ}$

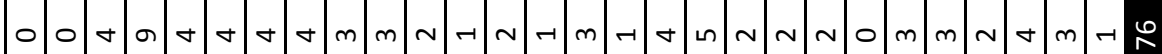

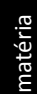

(

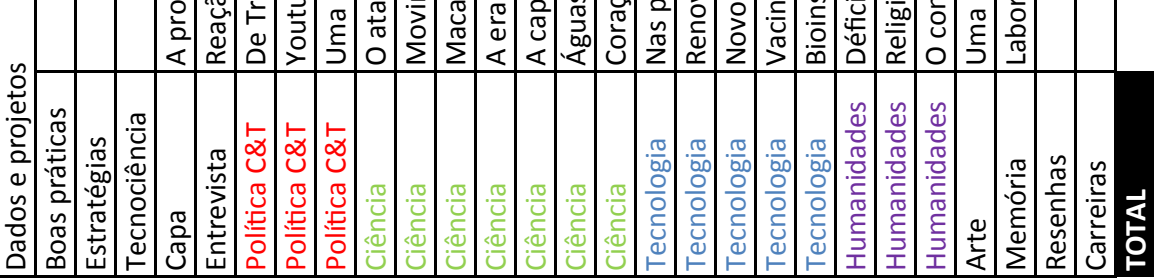

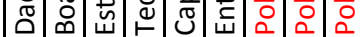


APÊNDICE A. Levantamento dos recursos gráficos (ed.244)

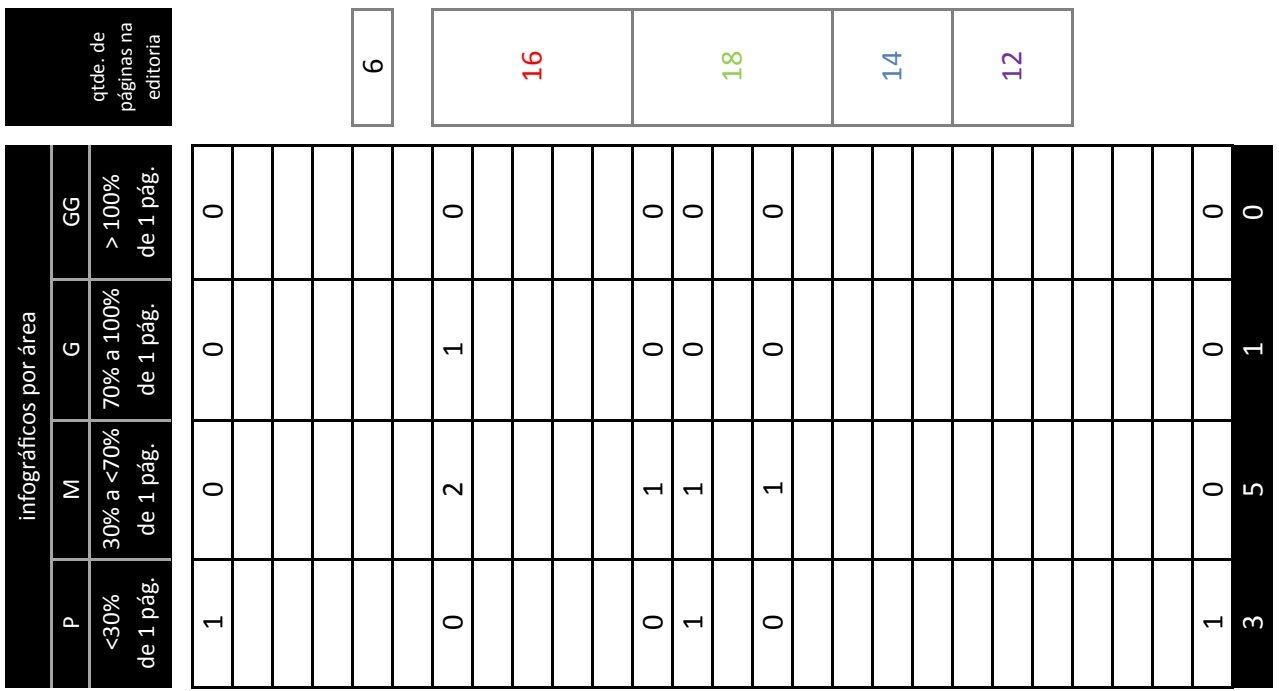

离

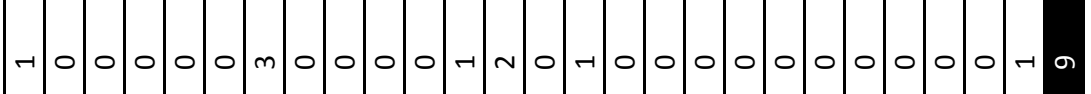

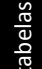

$\begin{array}{llllllllllllllllllllllllll}0 & 0 & 0 & 0 & 0 & 0 & 0 & 0 & 0 & 0 & 0 & -1 & 0 & 0 & 0 & 0 & 0 & -1 & 0 & 0 & 0 & 0 & 0 & 0 & 0 & 0\end{array}$

总

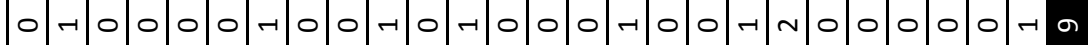

$\stackrel{\circ}{\circ}$

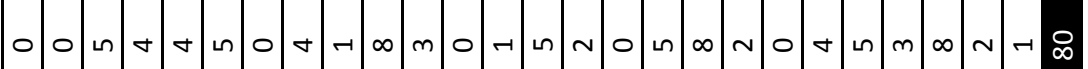

爵

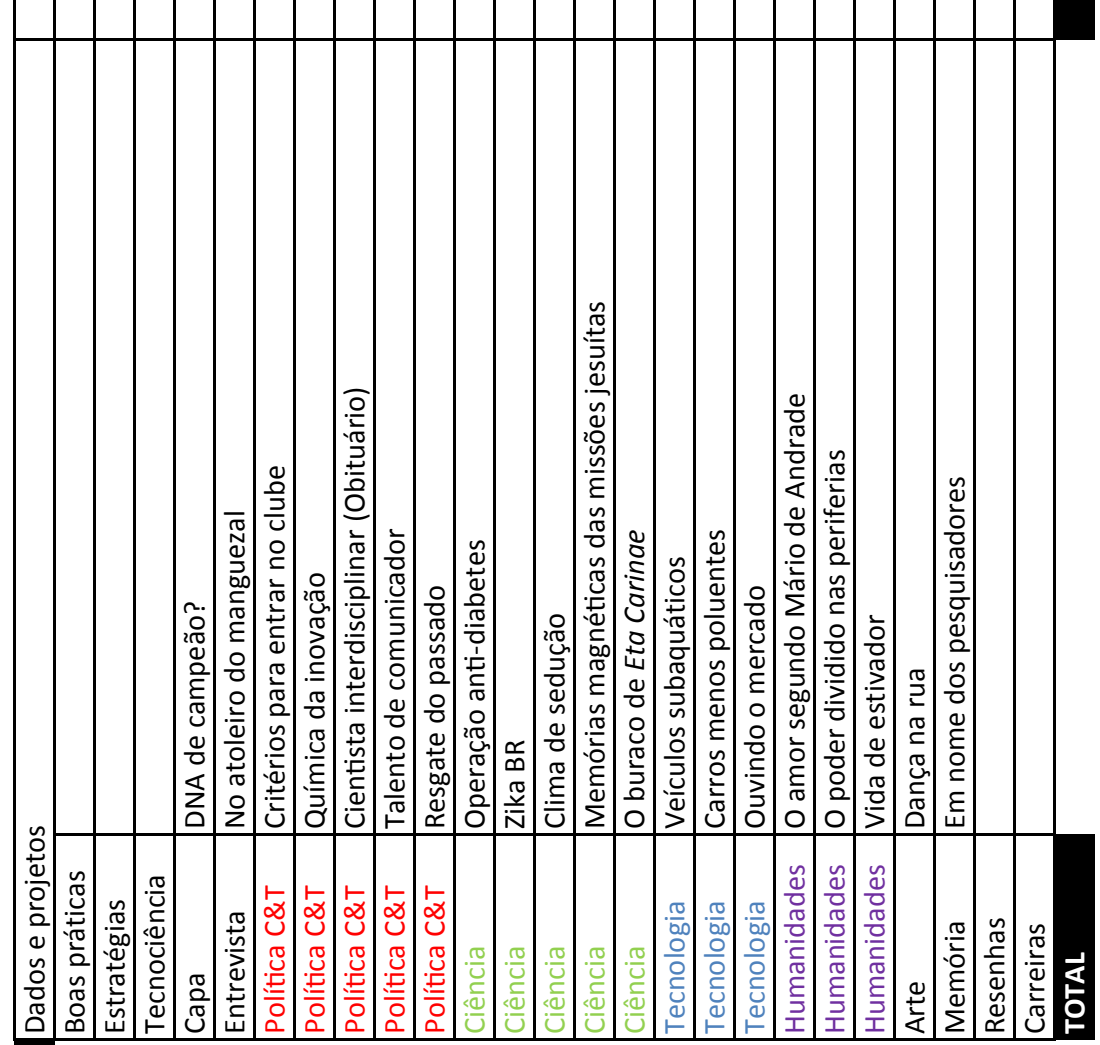

递

志 
APÊNDICE A. Levantamento dos recursos gráficos (ed.245)

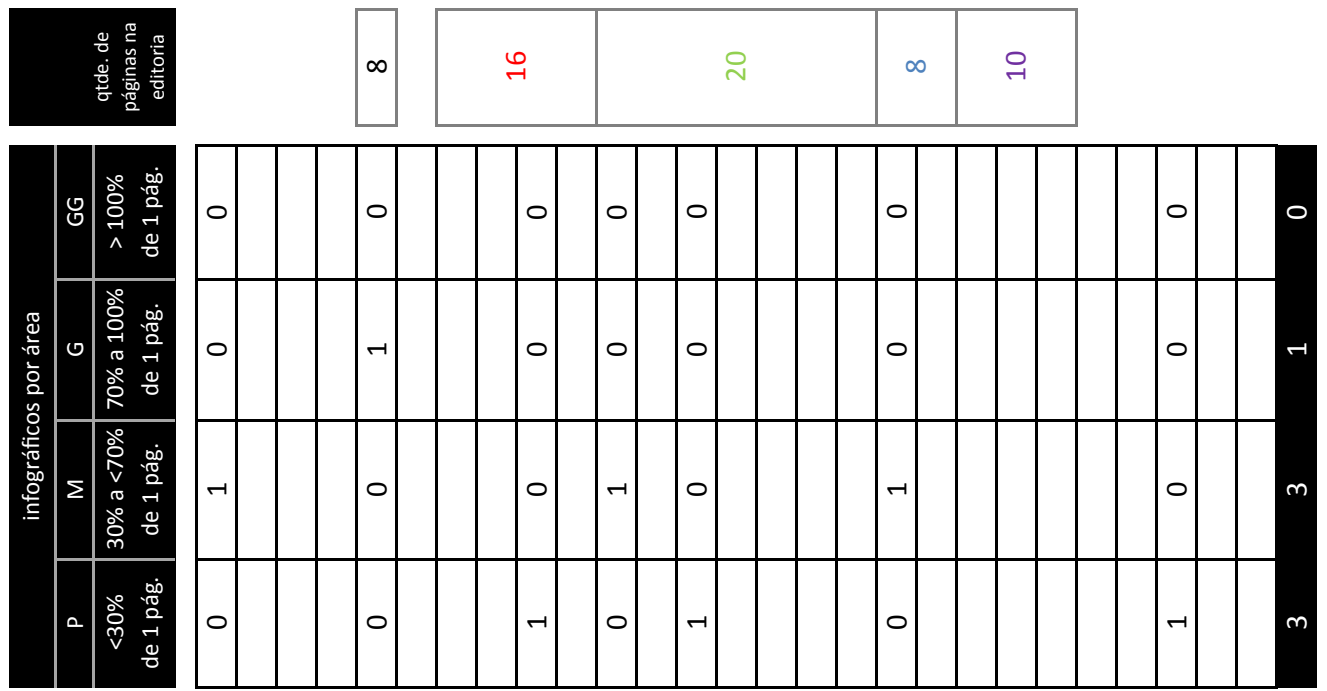

离

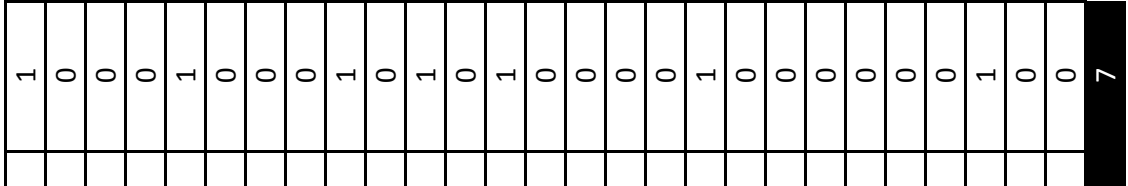

$\frac{\sqrt{2}}{\frac{8}{8}}$

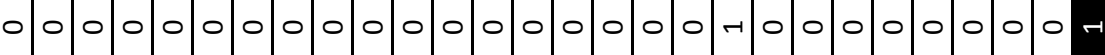

总

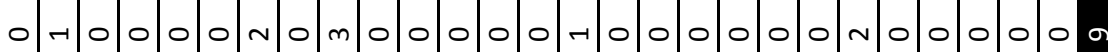

总

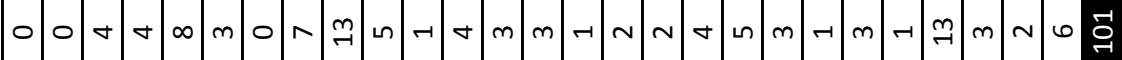

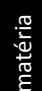

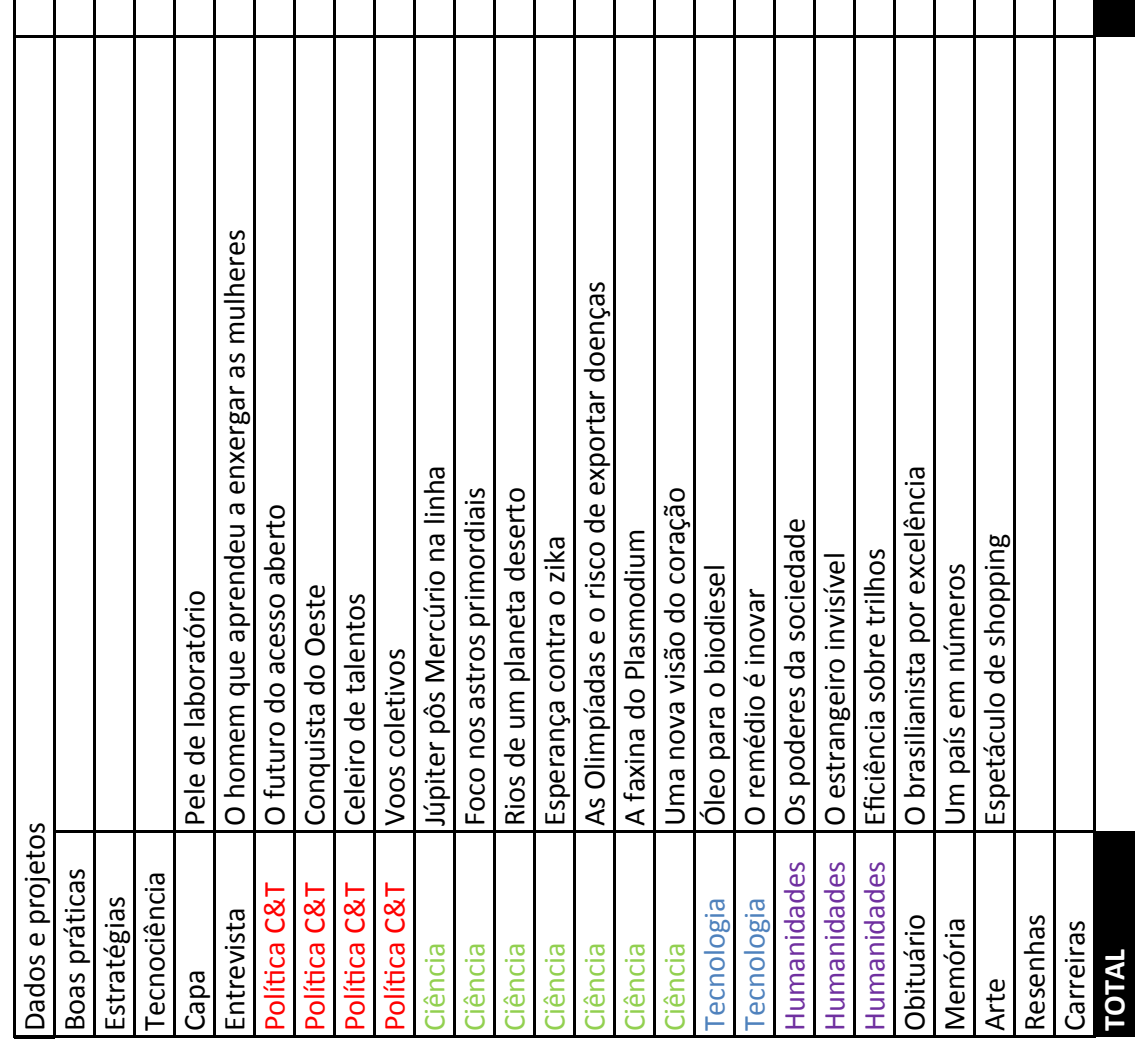

递

尔 
APÊNDICE A. Levantamento dos recursos gráficos (ed.246)

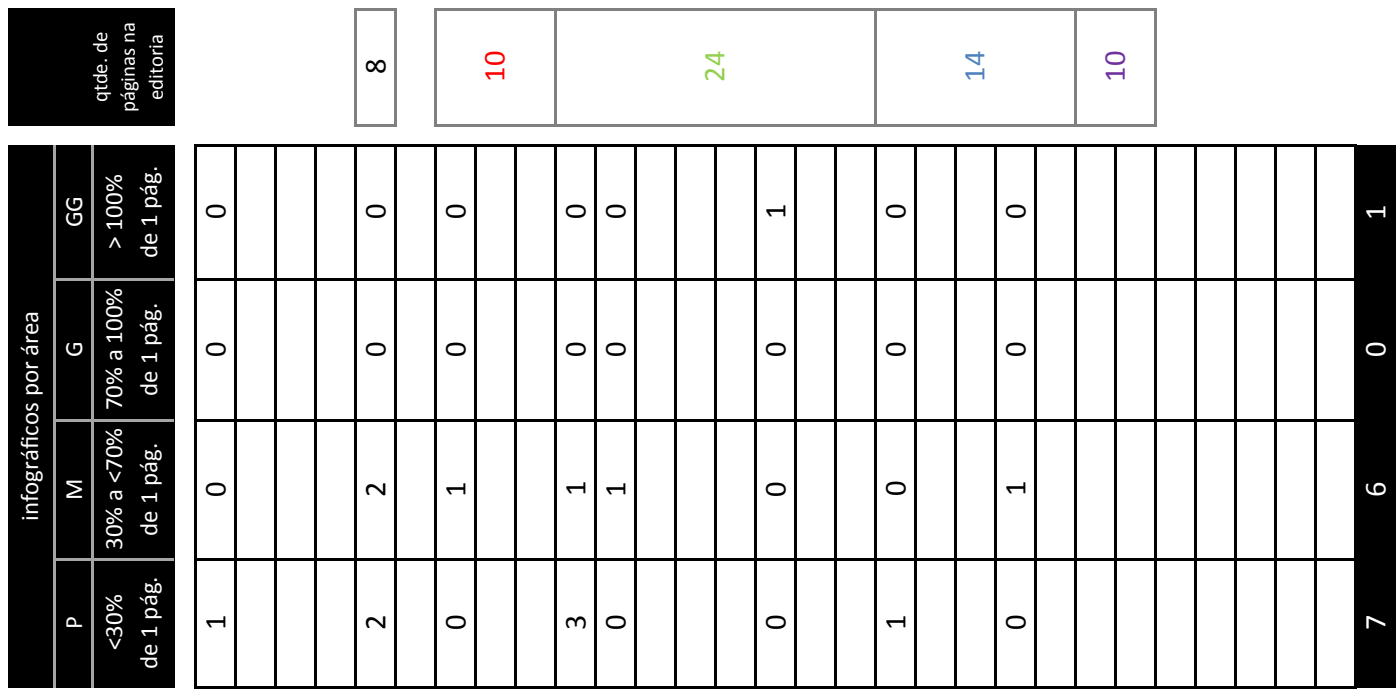

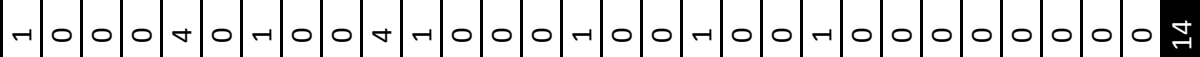


APÊNDICE A. Levantamento dos recursos gráficos (ed.247)

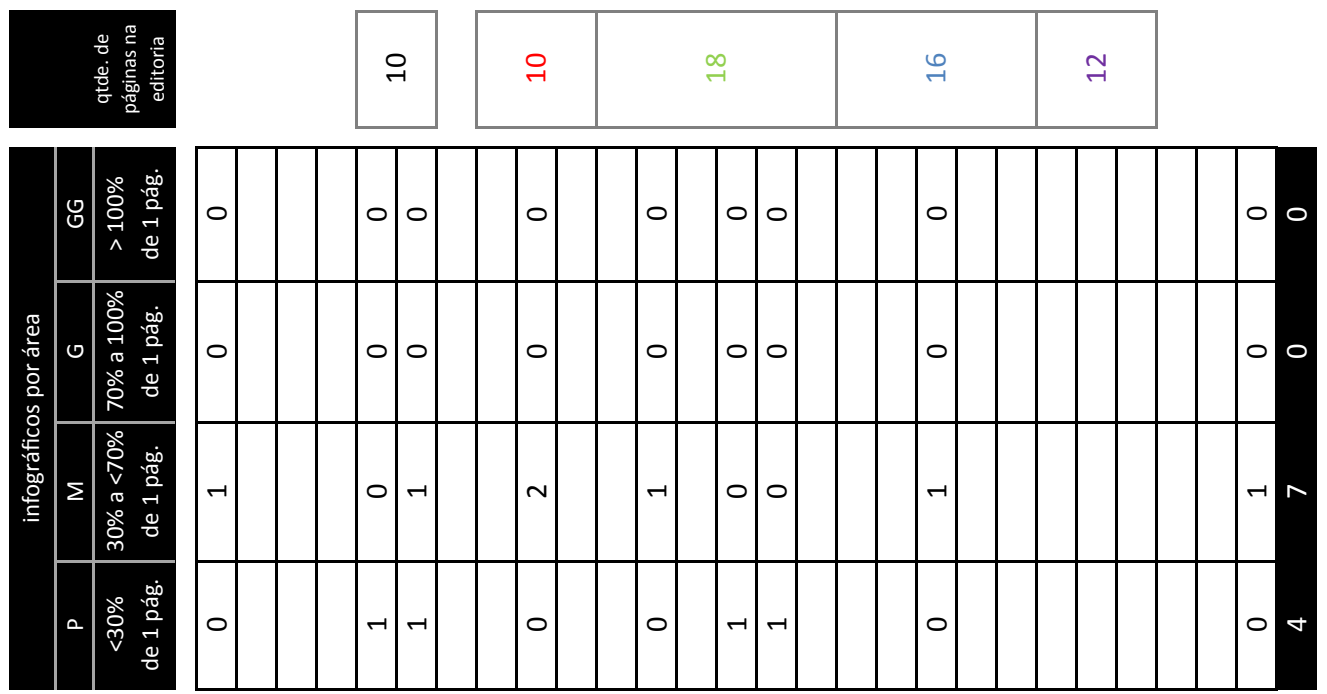

离

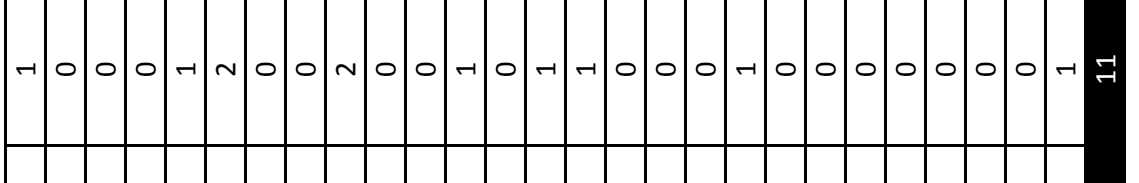

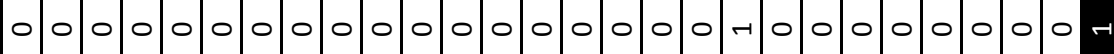

总

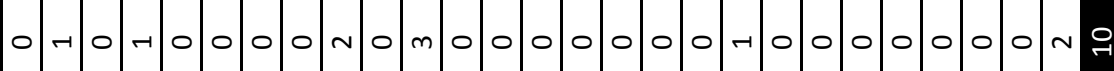

荾

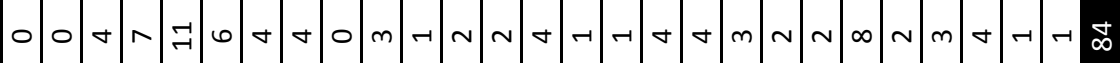

㩊

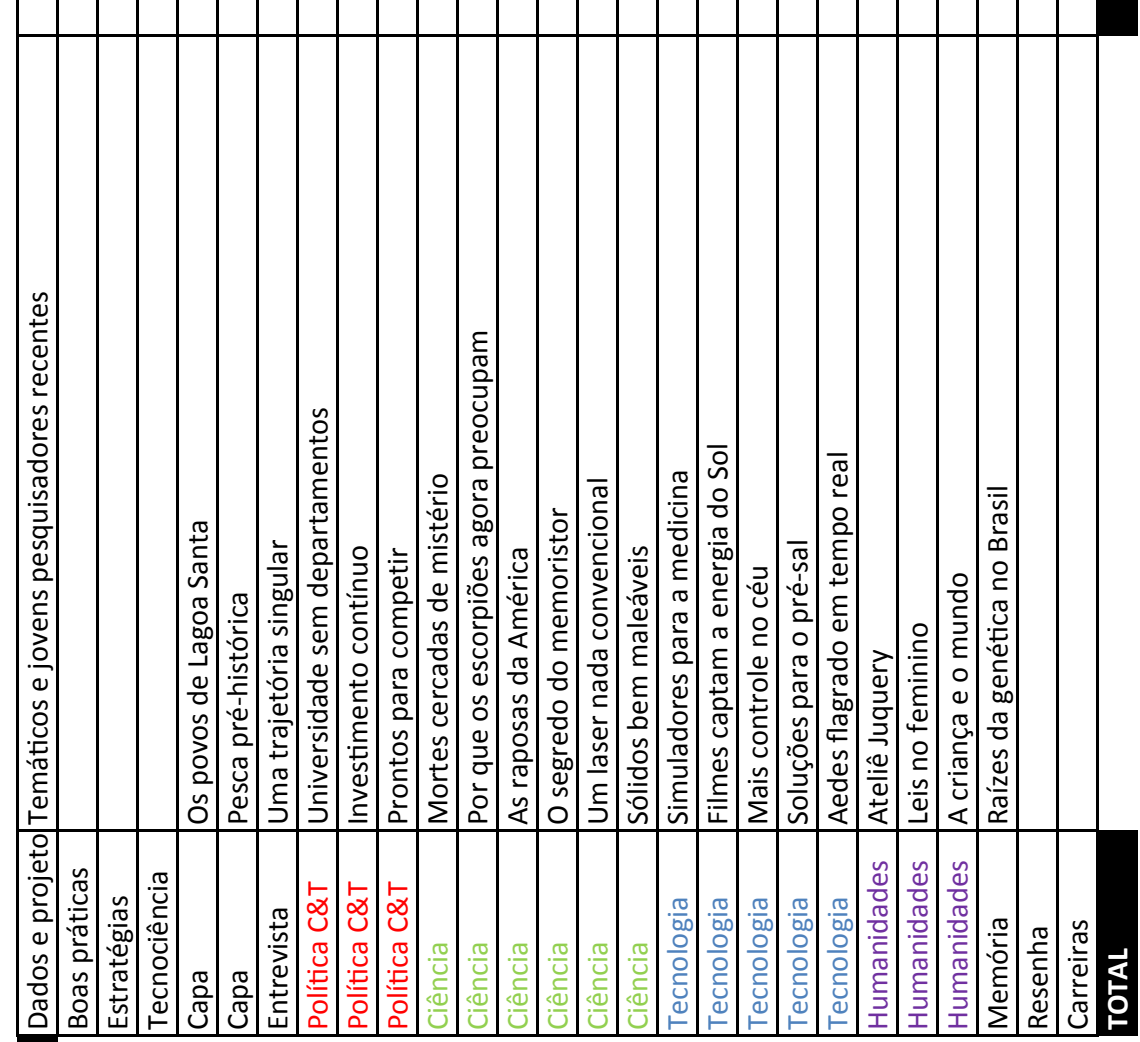

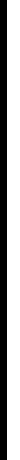

웛

f

藍

잉 
APÊNDICE A. Levantamento dos recursos gráficos (ed.248)

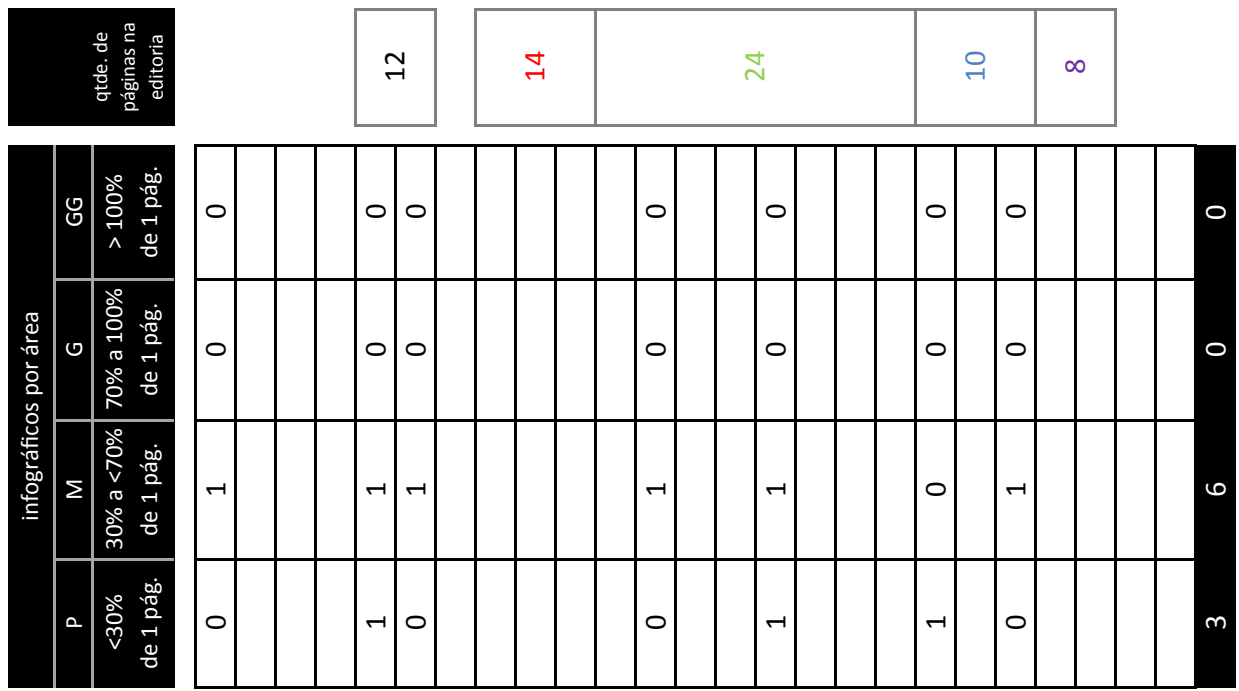

离

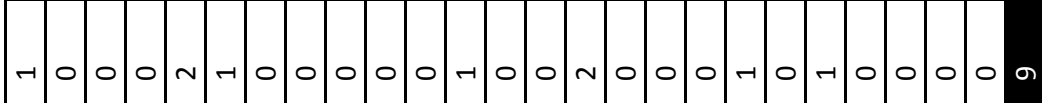

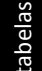

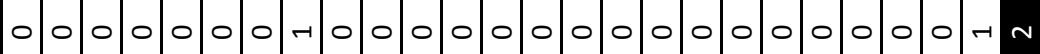

总

鄫

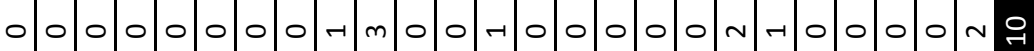

$\stackrel{\circ}{\circ}$

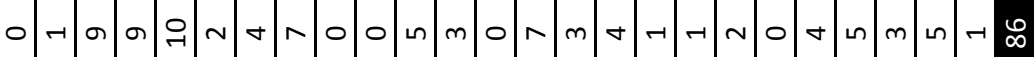

产

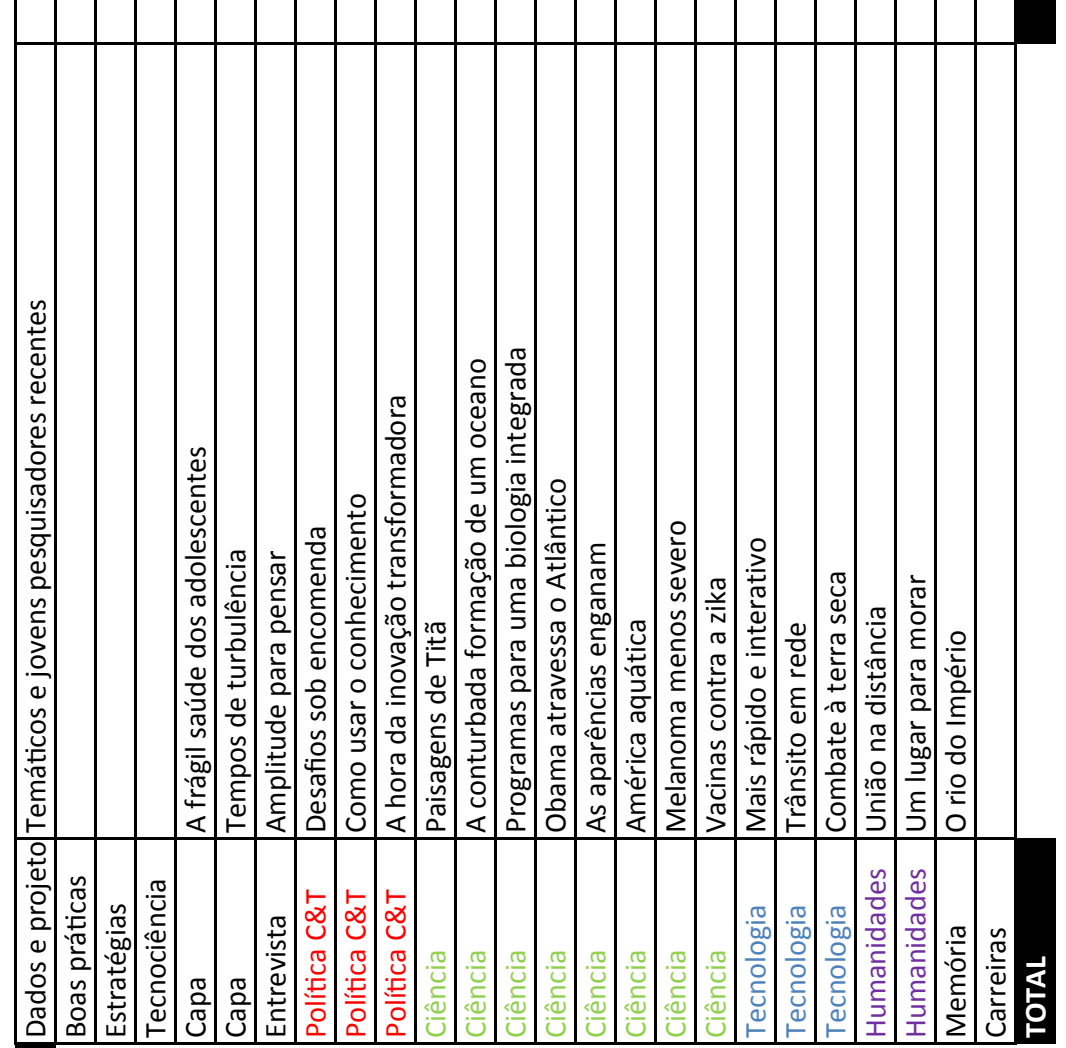

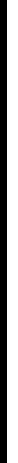

웛

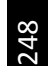

禺

웅 
APÊNDICE A. Levantamento dos recursos gráficos (ed.249)

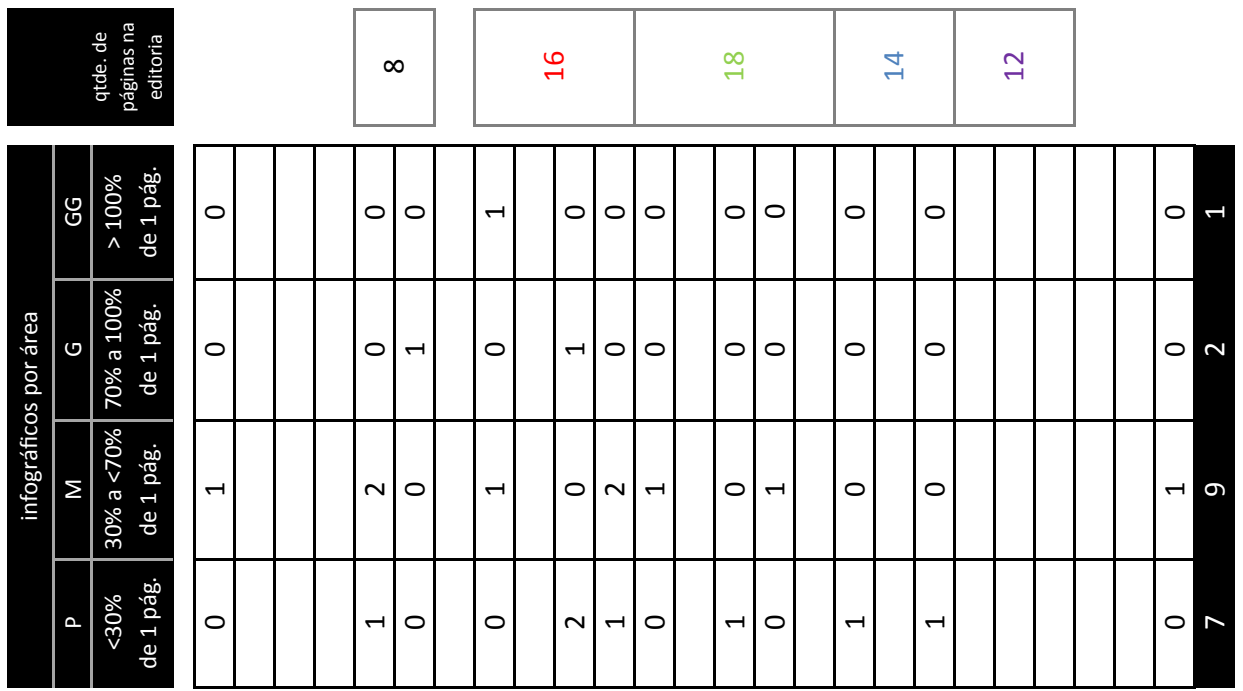

离

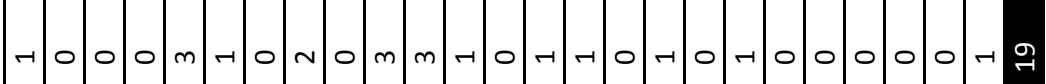

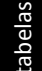

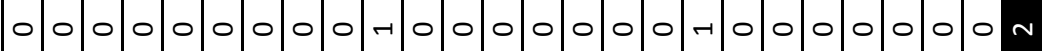

总

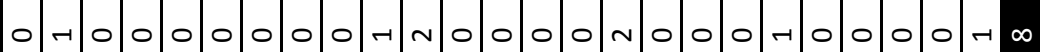

荾

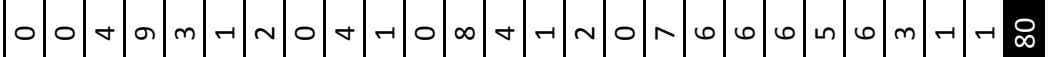

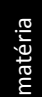

党

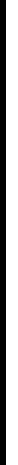

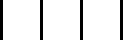

$\frac{\frac{\pi}{2}}{\frac{\bar{z}}{\alpha}}$

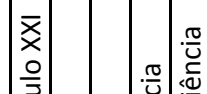

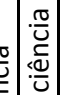

政。

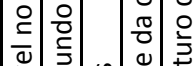

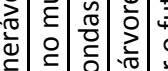

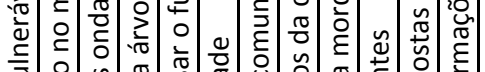

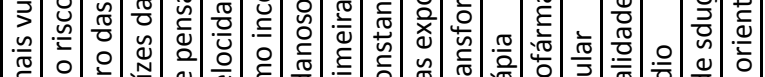

药

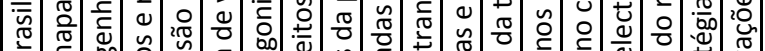

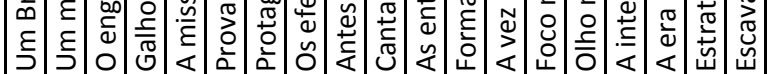

造

总

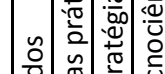

×

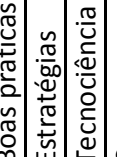

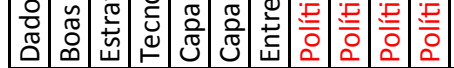


APÊNDICE A. Levantamento dos recursos gráficos (ed.250)

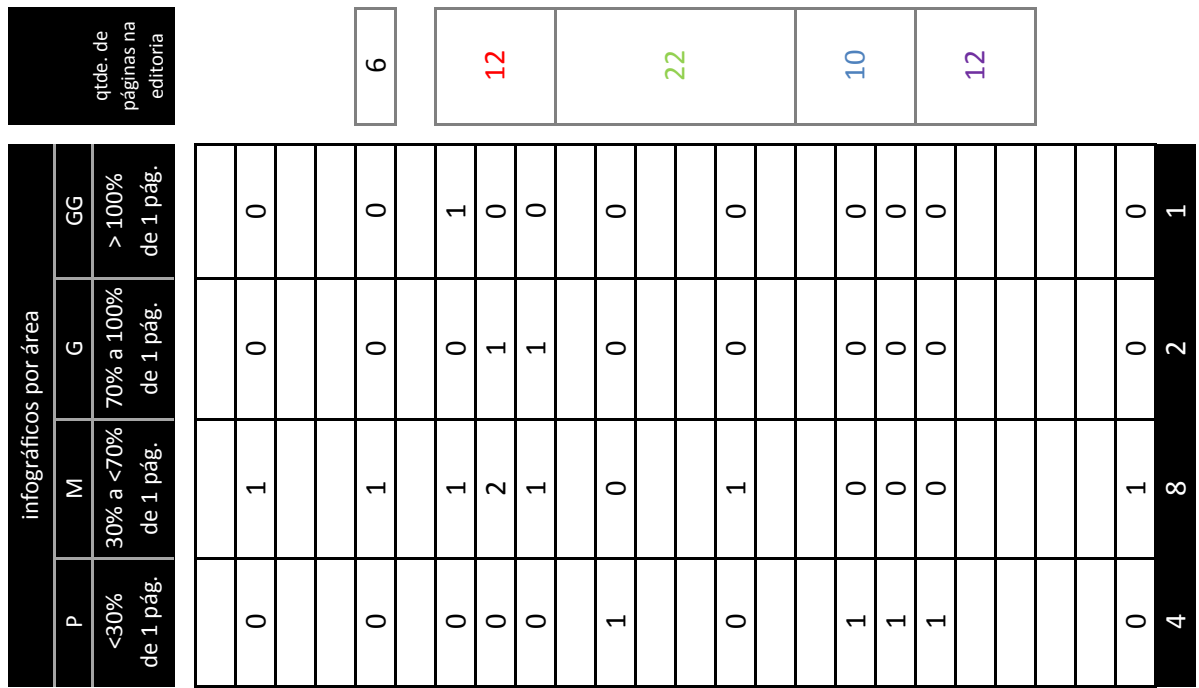

离

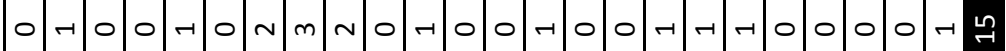

带

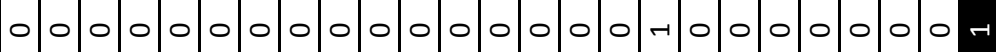

总

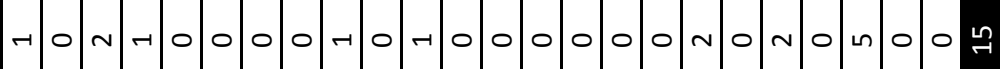

$\stackrel{\circ}{\circ}$

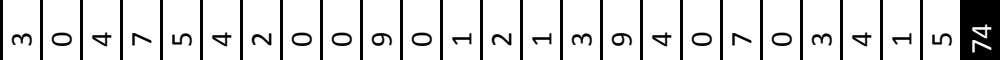

产

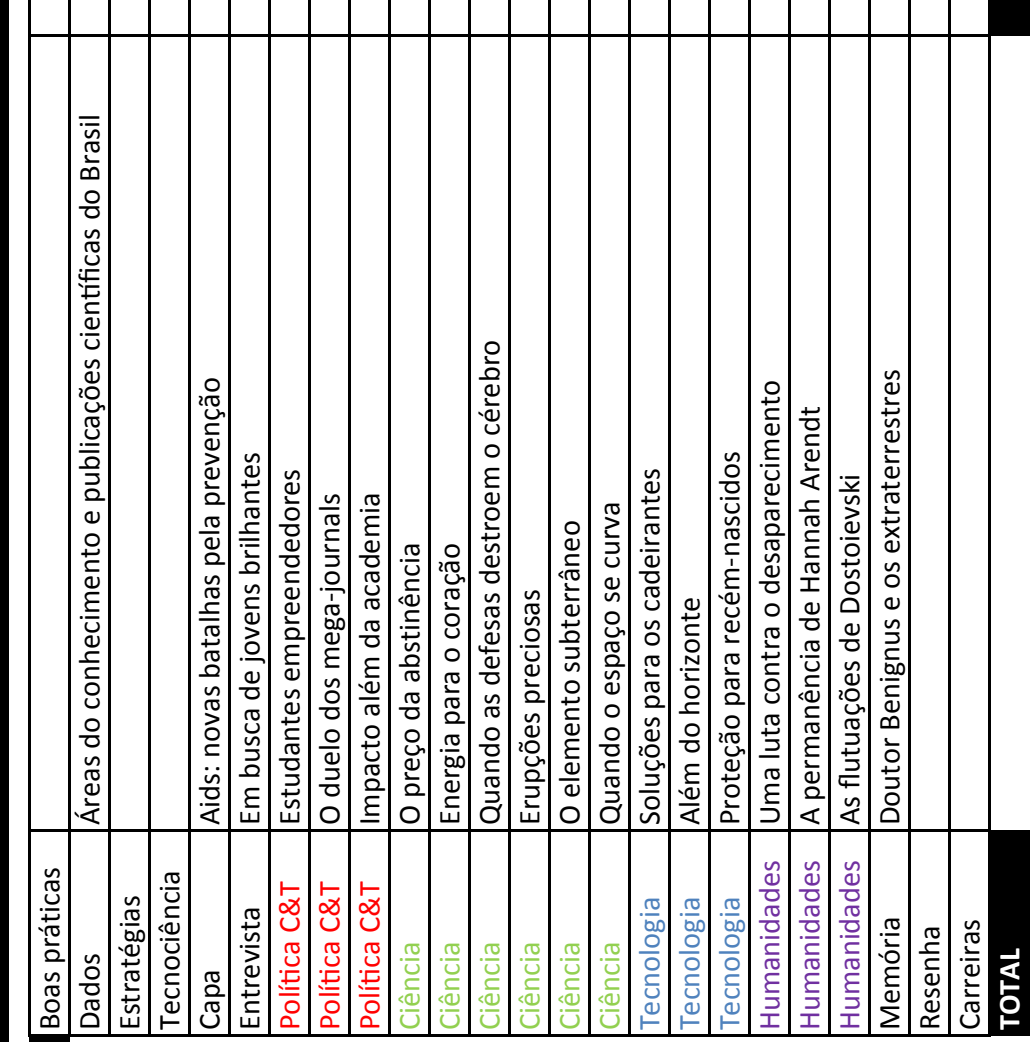

愛

in 
APÊNDICE A. Levantamento dos recursos gráficos (ed.251)
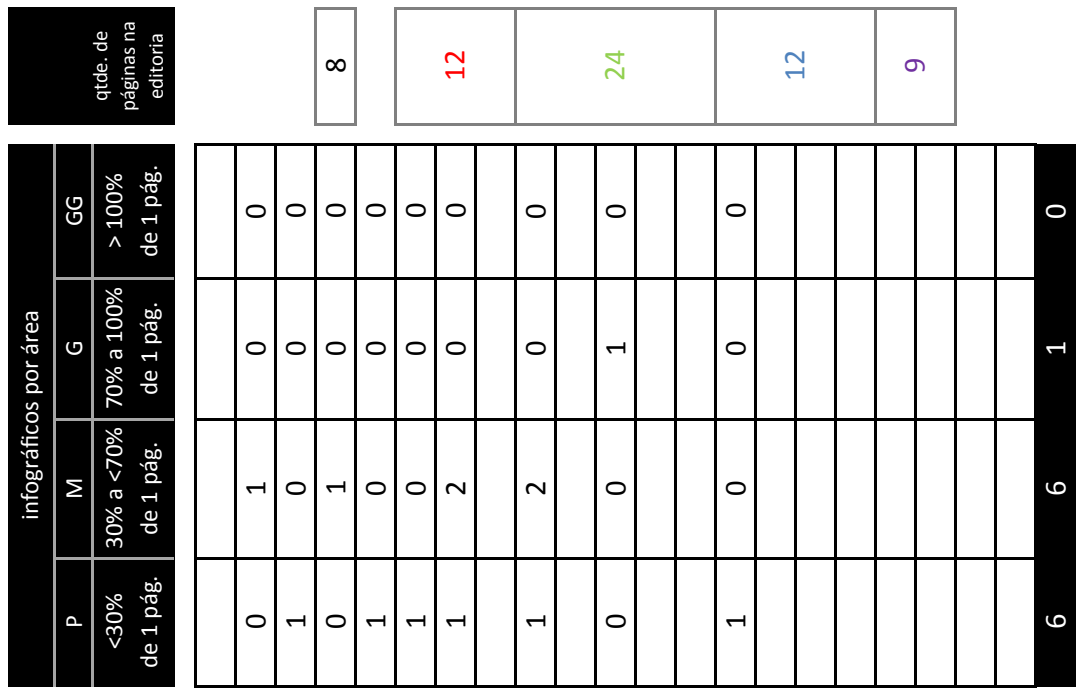

离

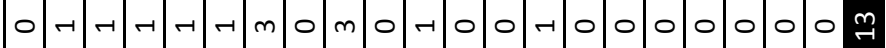

$\frac{\frac{\pi}{0}}{\frac{\pi}{\mathbb{g}}}$

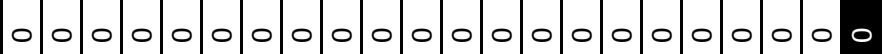

总

总

$\stackrel{\circ}{\circ}$

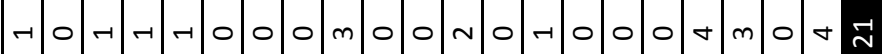

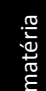

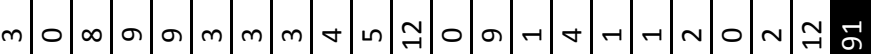

爱

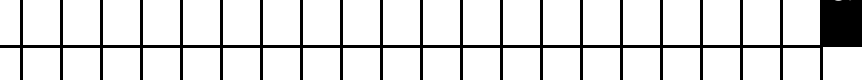

웛

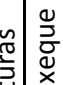

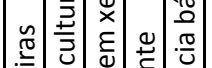

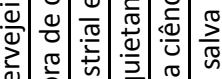

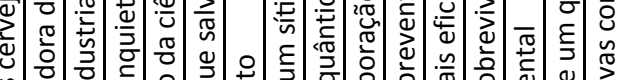

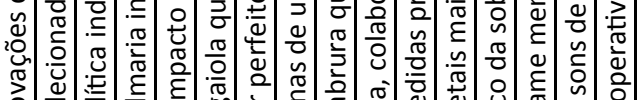

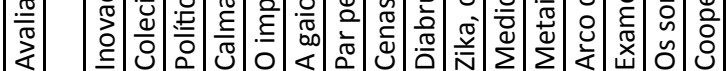

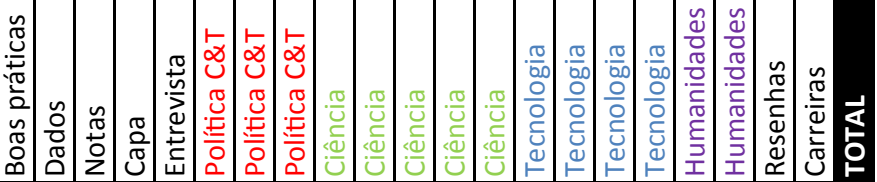


APÊNDICE A. Levantamento dos recursos gráficos (ed.252)

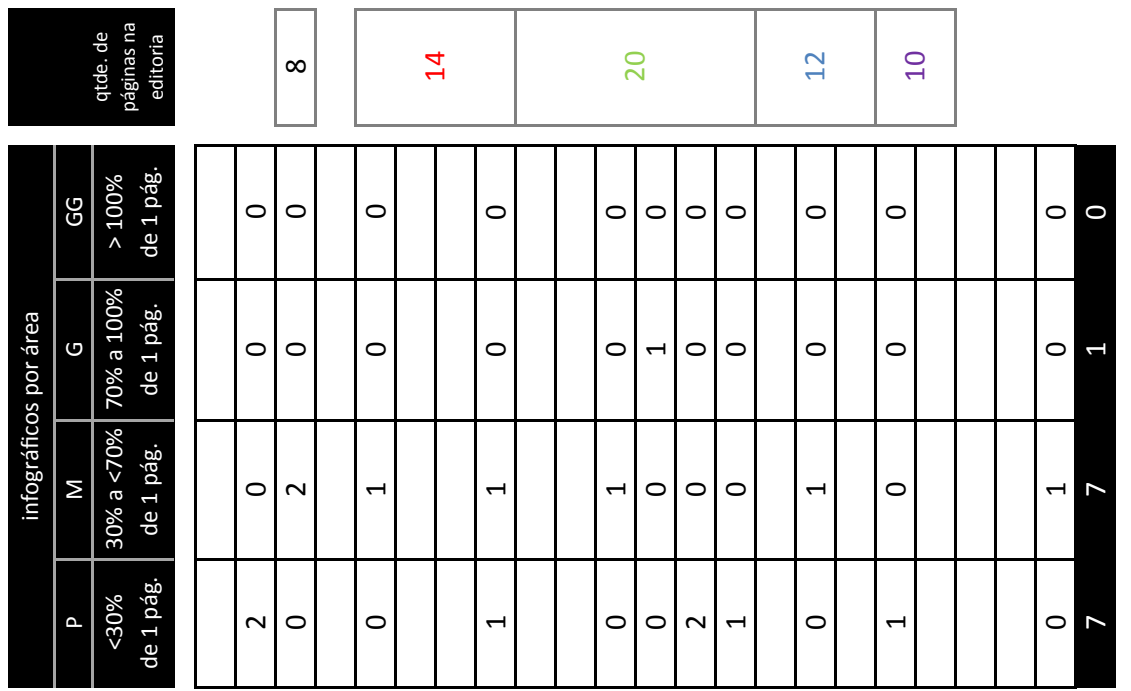

离

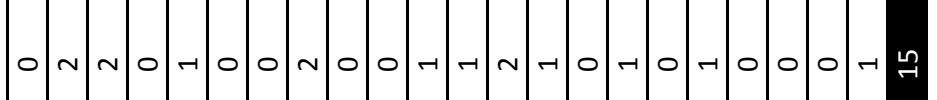

$\frac{\mathscr{0}}{\mathbb{D}}$

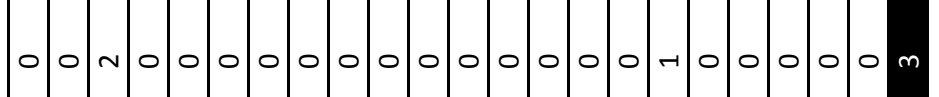

总

要

$\stackrel{\circ}{\circ}$

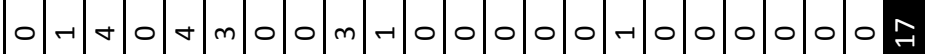

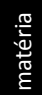

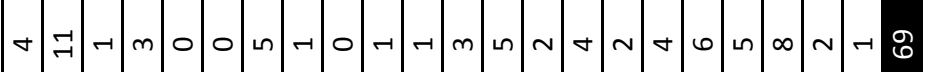

竞

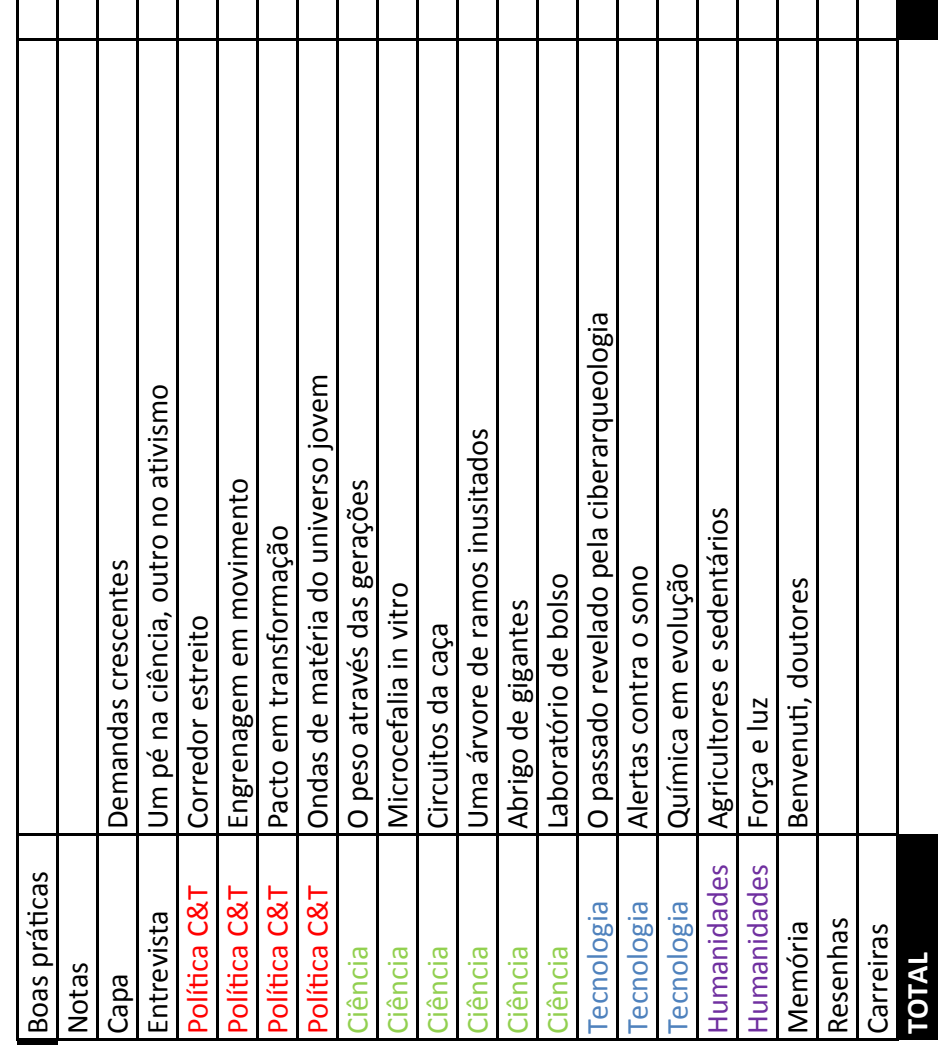

웛

กี 
APÊNDICE A. Levantamento dos recursos gráficos (ed.253)

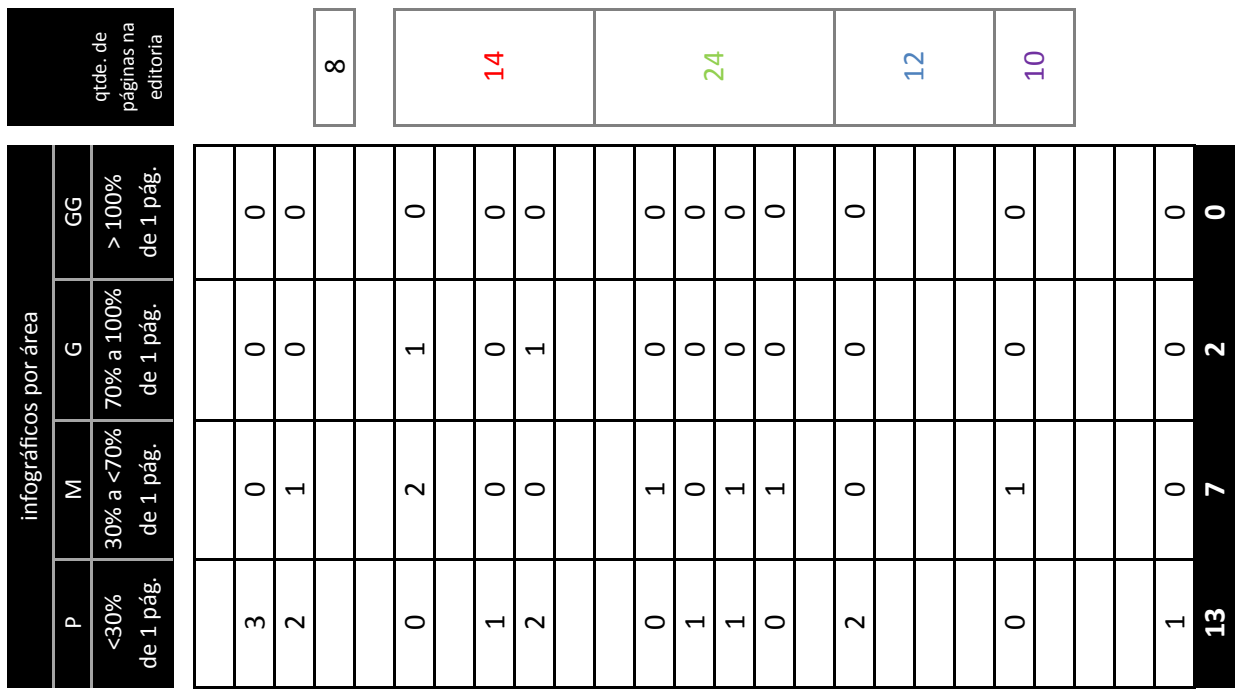

离

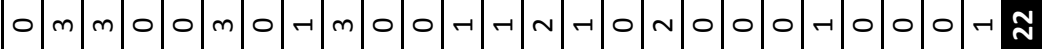

$\frac{\mathscr{0}}{\mathrm{g}}$

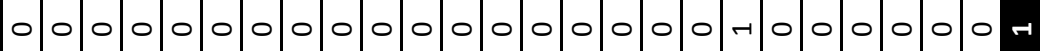

.

产

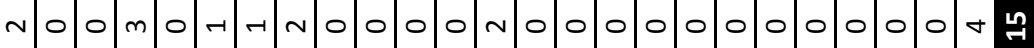

谷

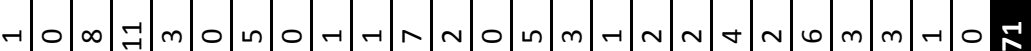

愛

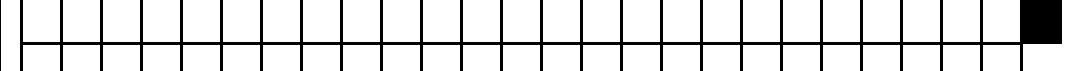

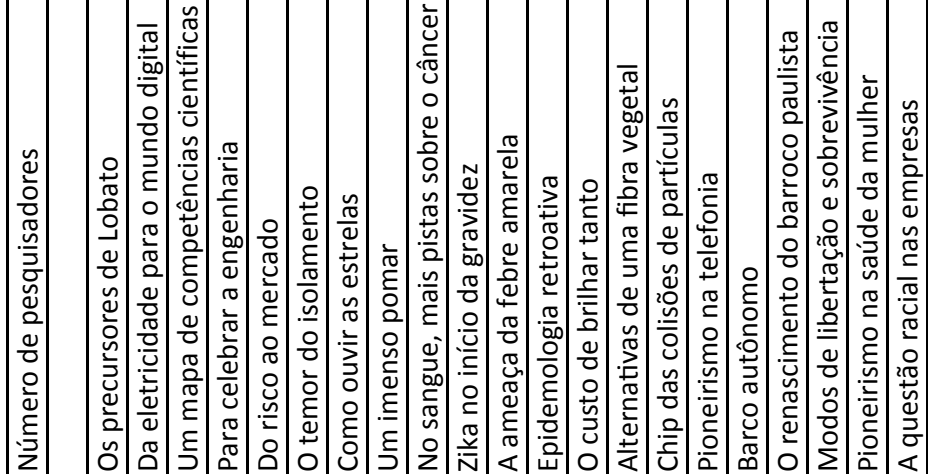

홍

告

递

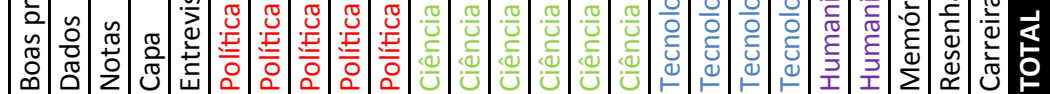


APÊNDICE B. Aplicação do protocolo de análise ao corpus (parte 1)

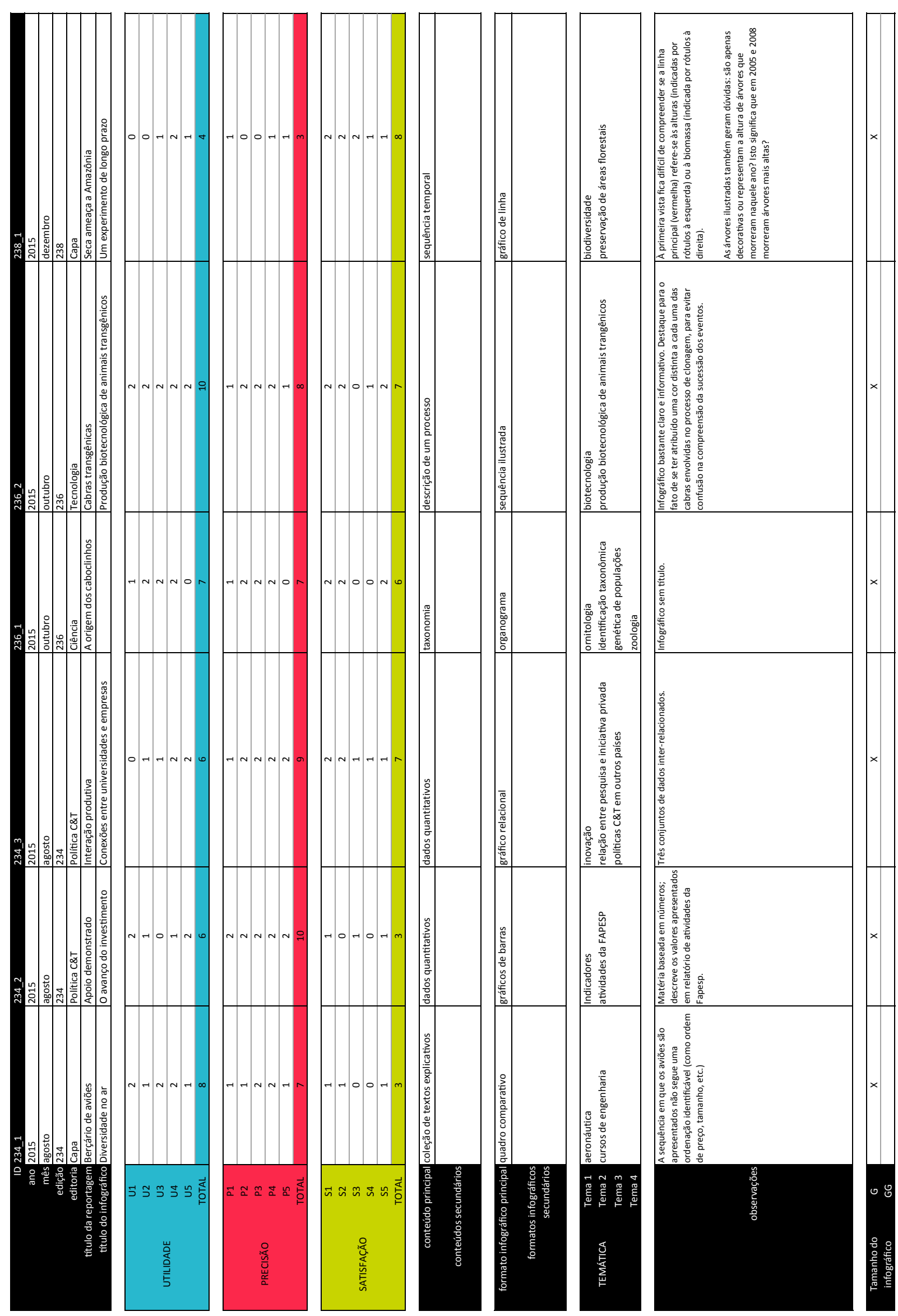


APÊNDICE B. Aplicação do protocolo de análise ao corpus (parte 2)
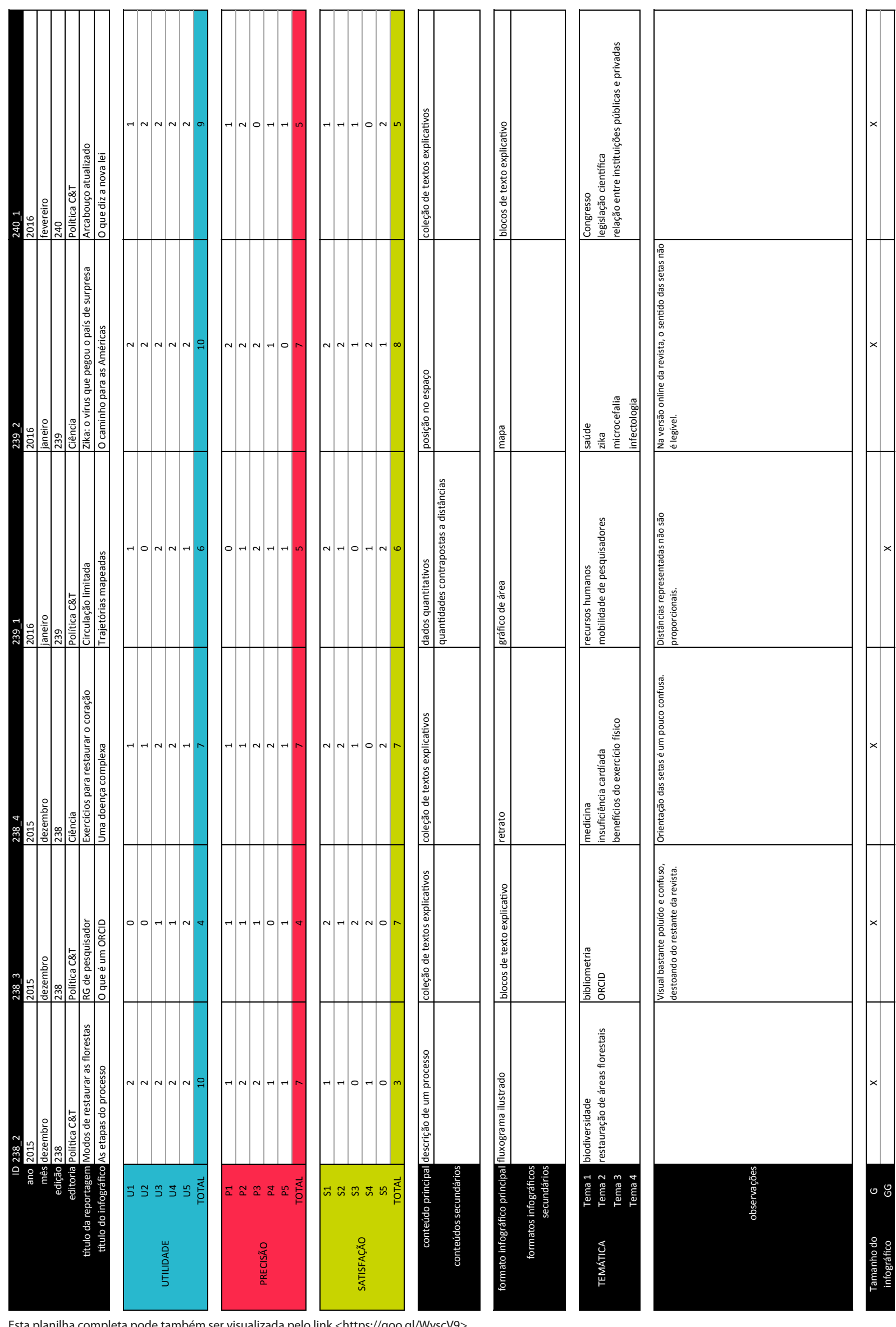

Esta planilha completa pode também ser visualizada pelo link <https://goo.gl/WyscV9>. 
APÊNDICE B. Aplicação do protocolo de análise ao corpus (parte 3)

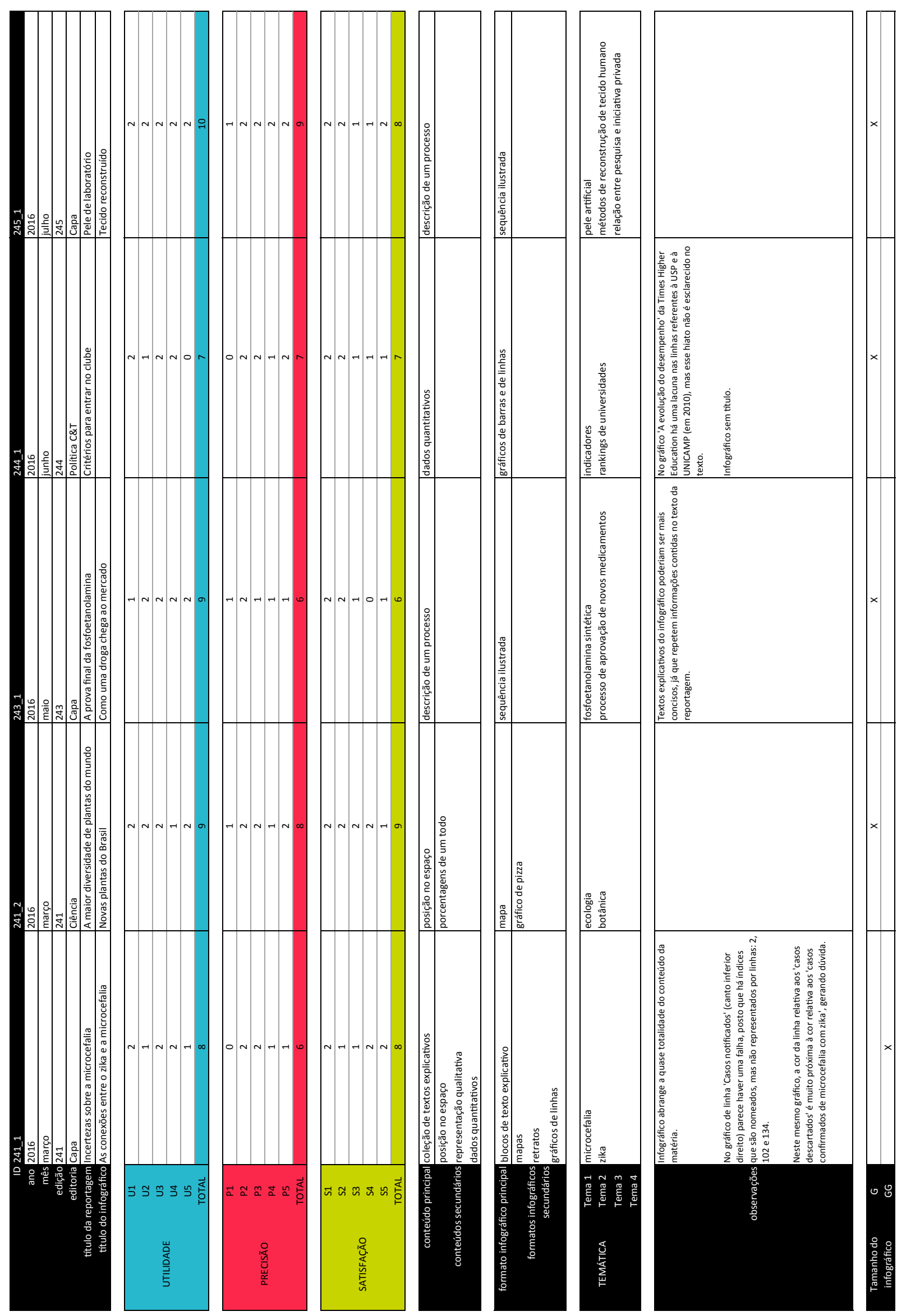


APÊNDICE B. Aplicação do protocolo de análise ao corpus (parte 4)
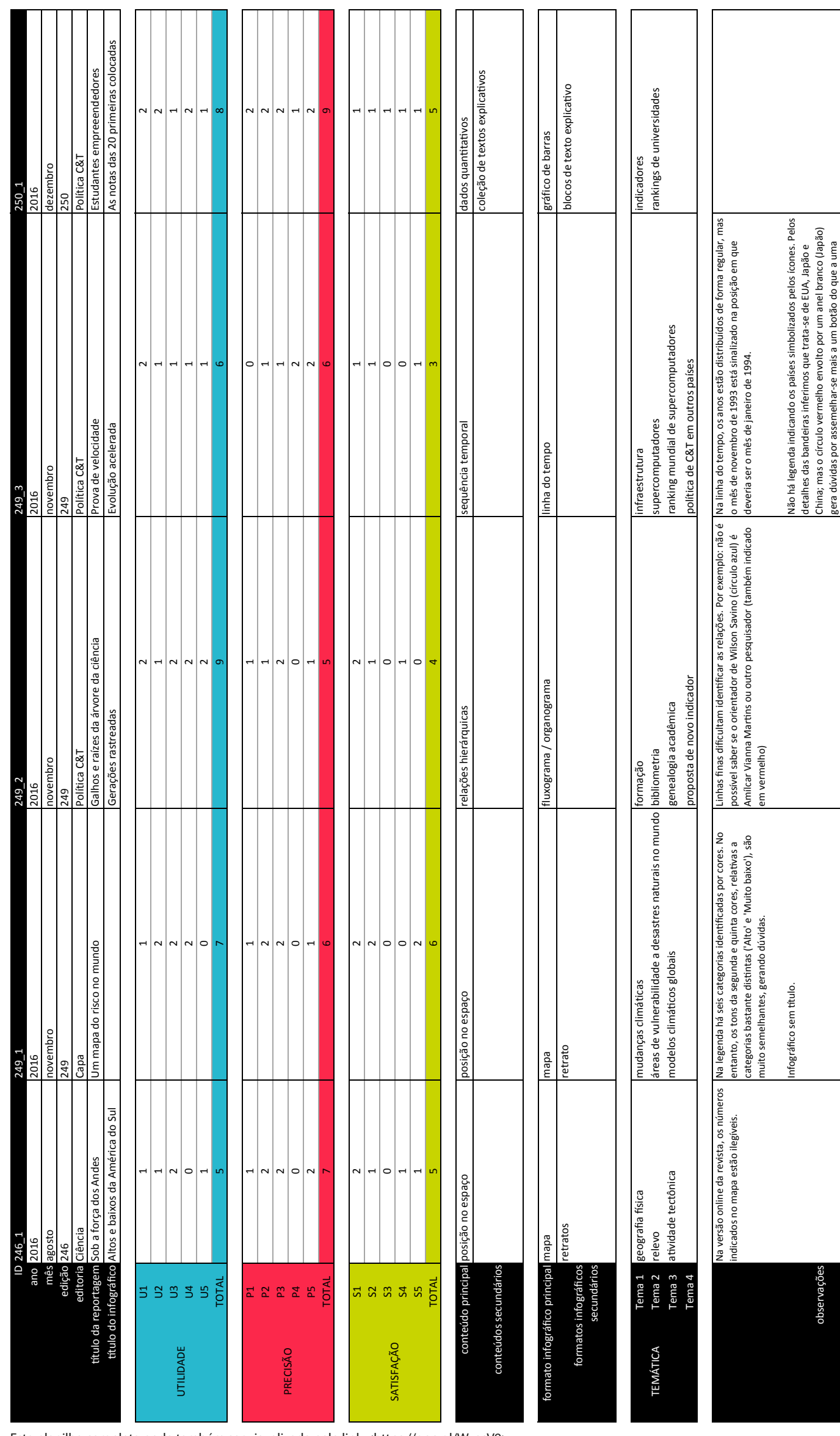

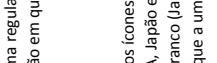

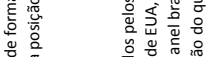

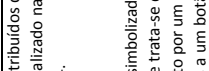

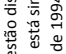

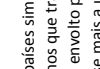

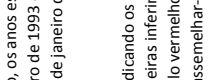
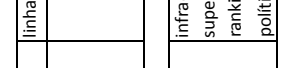

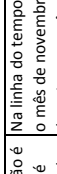

离

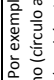

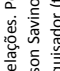

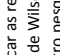

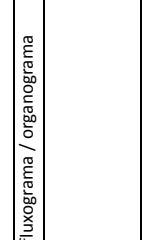

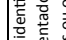

要

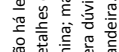

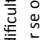

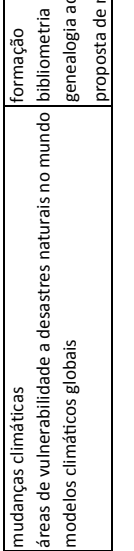

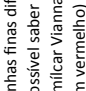

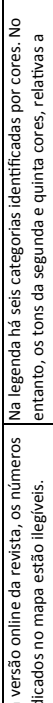
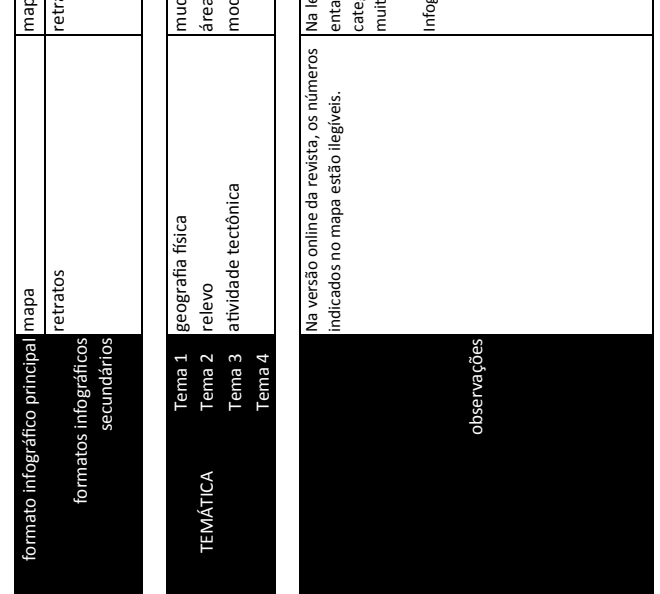

Esta planilha completa pode também ser visualizada pelo link 〈https://goo.gl/WyscV9〉. 
APÊNDICE B. Aplicação do protocolo de análise ao corpus (parte 5)
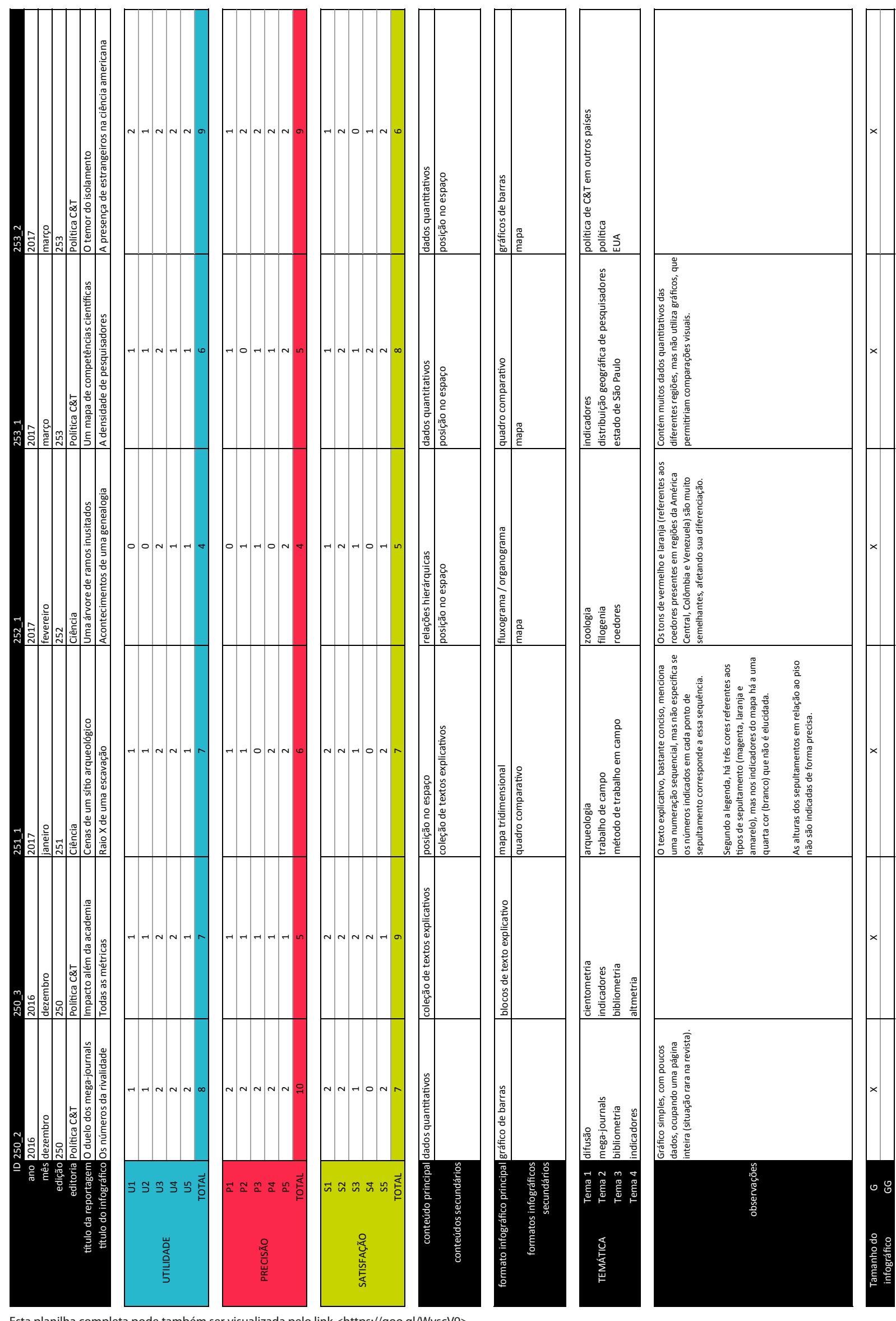

Esta planilha completa pode também ser visualizada pelo link <https://goo.gl/WyscV9>. 